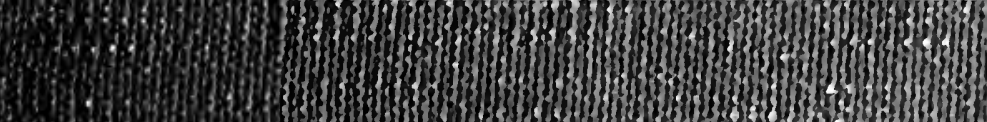

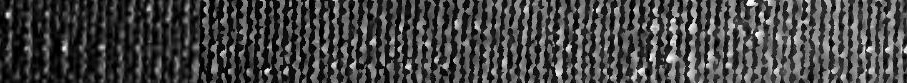
6)

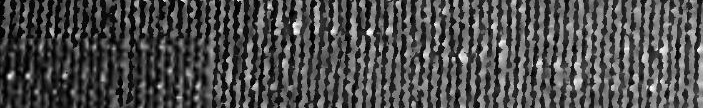
(3) 13.

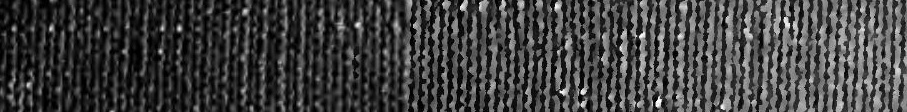
6.5. 2.3. 9.2. 4. 615 6.

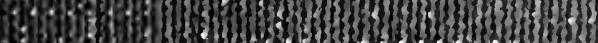
2.5.

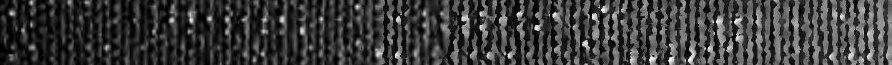
Whath

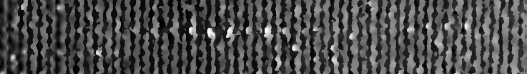
5.5.

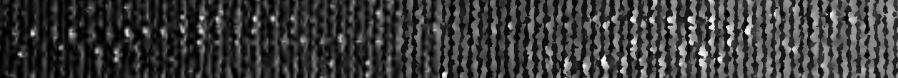

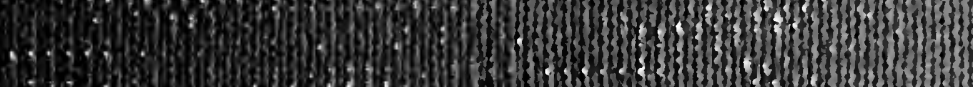
275 .

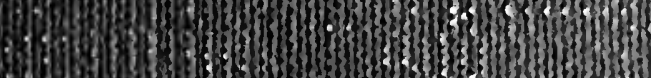

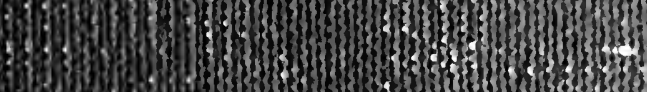
6.7. 2.7. 4. 3 3. 3) 65:3 5rats 233 330 35133) A. 19.20 258 .

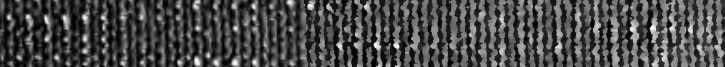
2.7. 3 . T. (7) S? 3.5. 3 3. Q728

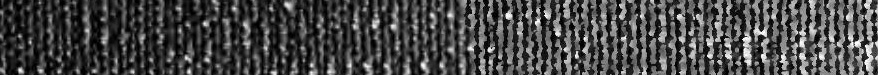









\section{AN IEPTOME}

of THE:

BY

\section{ROSWELL, PARK, A.M., M.D.,}

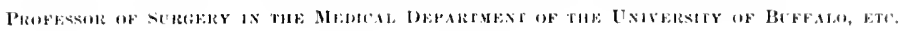

BASED UPON A COURSE OF LECTURES DELIVERED IN THE UNIVERSITY OF BUFFALO.

\section{SECOND EDITION.}

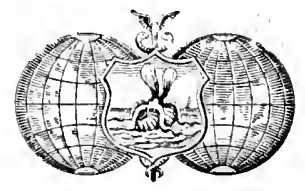

Philanelphi, New York, CHICho:

TIIE F. A. DAYIS COMPANY, PUBLISHERS. 1,899 


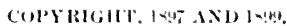

M

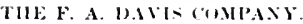

[Registerel at statinuers' Hall, Imutun. Enz.]

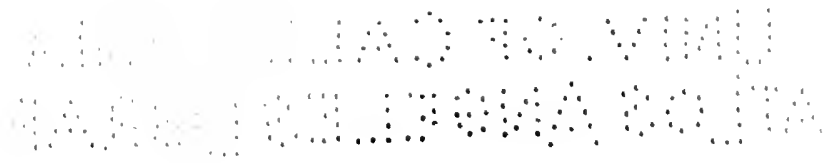

Philateluhia. Pa., U. S. A.

The Medical Bulletin Printing-Itouse,

1916 Cherry street. 
"Destin! Reseres for us Repose Enomyh."-FERNEL.

\section{TO MY COLLEAGUES}

IN TILE

MEDICAL FACULTY OF THE UNIVERSITY OF BUFFALO,

Who Authonzen ang Excolknged this First Attempt IN TIE MEdiCal SCHOOLS (IF THIS COUXTRY TO GIVE Sistenatic INSTRECTION IN THE HISTORY of the SCHexce Which ther Teach,

THIS BOOK

IS DEDICATED. 



\section{PREFACE TO THE SECOND EDITION.}

That a second edition of a work of this character should be called for within a year after the appearance of the first is naturally a source of the greatest satisfaction to its writer, while it indicates as well that his sincere hope has been fulfilled, in that the profession generally are manifesting a deep, genuine interest in the important subjects of which it briefly treats. This las been so uniformly the expressed opinion of the book reviewers that I lave been the more anxious to correct the trifling errors inseparable from the first appearance of any book, and even venture to agree with them, in the hope that a larger and more comprehensive work may yet be the outcome of an interest in this History of Medicine. Particularly am I indebted to those who have kindly taken the trouble to call my attention to a few inaccuracies contained in the first edition; and I wish here to express my obligation to them all, and especially to Dr. Auzal, of New York, for kind services of this character. 'The only regret of the author is that, in a work of this necessarily limited scope, it is possible to give only what the title indicates,-i.e., an epitome of the history of medicine, rather than a more comprehensive account, which alone should satisfy the more studious.

I have added a supplementary chapter on "Iatrotheurgic Symbolism," as being quite germane to the general subject of the book. It appeared originally as the "Annual Oration" delivered by invitation before the Maine Medical Association in June, 18.98, and is substantially reproduced from their Transactions.

Buffalo, N. Y., November, 1898. 


\section{PREFACE.}

THE history of medicine has been sadly neglected in our medical schools. The raluable and fruitful lessons which it tells of what not to clo have been completely disregarded, and in consequence the same gross errors have over and over been repeated. 'The following pages represent an effort to bring the most important facts and events comprised within such history into the compass of a medical curriculum, and, at the same time, to rehearse them in such manner that the book may be useful and acceptable to the interested layman,-i.e., to popularize the subject. This effort first took form in a series of lectures given in the Medical Department of the University of Buffulo. The subject-matter of these lectures laas been rearranged, cnlarged, and edited, in order to make it more presentable for easy reading and reference. I have also tried, so fur as I conld in such brief space, to indicate the relationship which has ever existed between medicine, philosophy, natural science, theology, and eren belles-lettres. Particularly is the history of medicine inseparable from a consideration of the various notions and beliefs that have at times shaken the very foundation of Christendom and the Church, and for reasons which appear throughout the book.

The history of medicine is really a history of human error and of human discovery. During the past two thousand years it is hard to say which has prevailed. Notwithstanding, had it not been for the latter the total 
of the former would have been vastly greater. A large part of my effort has been devoted to considering the causes which conspired to prevent the more rapid development of our art. If among these the frowning or forbidding attitude of the Church figures most prominently, it must not be regarded as any expression of a quarrel with the Churrch of to-day. But let any one interested read President White's History of the Wurfure of Science with Theology, the best presentation of the subject, and he can take no issue with my statements.

Reverence for the true, the beautiful, and the good has characterized physicians in all times and climes. But little of the true, the beantiful, or the good crept into the transactions of the Church for many centuries, and we suffer, to-day, more from its interference in time past than from all other causes combined. The same may be said of theology, which is as separate from religion as darkness from light. Only when students of science emancipated themselves from the prejudices and superstitions of the theologians did medicine make more than barely perceptible progress.

In this connection I would like to quote a paragraph from an article by King, in the Nineteenth Century for 1893: "The difficulties under which medical science labored may be estimated from the fact that dissection was forbidden by the clergy of the Middle Ages on the gromd that it was impious to mutilate a form made in the image of God. We do not find this pious objection interfering with such mutilation when effected by means of the rack and wheel and such other clerical, rather than medical, instruments."

Written history is, to a certain extent at least, pla- 
giarism; and I make no apology for having borrowed my facts from whaterer source could best furnish them, but wish cheerfully and publicly to acknowledge my indebtedness to the works mentioned below, those especially of Renouard, Baas, and sprengel, and to various biographical dictionaries. I have not even scrupled to take bodily sentences or expressions from these anthorities, but have tried to so indicate them when I conld.

The witer takes pleasure in acknowledging here the obligations which both he and the publishers fecl to 1 r. Joseph H. Hunt, of Brooklyn, X. Y., from whose extensive and valuable collection have been fumished the originals for most of the portraits in the following pages, and to 1 )r. F. P. Henry. Honorary Librarian of the College of Physicians of Philadelphia, through whose contesy was obtained the privilege of reproducing the illustrations of instruments and operations fiom some of the rare old works in the college library. The lind co-operation of these grentlemen has given a distinct and added ralue to the contents of this little work.

\section{List of P'RINCIPAL WORKS CONGLLTED.}

BAas, Outlines of the Mistory of Medicine. Translated by Handerson. New Tork, 1-9.

BerDoe, origin and Groneth of the Healing Art. London, 1-93.

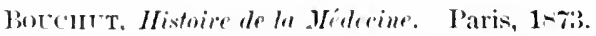

Dezeraners, Letlors sur l Histoire de le Médecine. Paris, 1833.

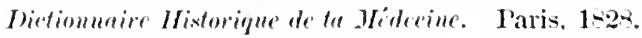

Gorrt, Gesshichte der Chimgie.

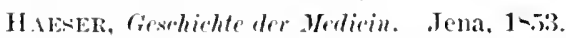

Herscit, Biographixhes Lerikon des Hewmeragenden der Aerzte aller Zeiten und rölker. Wien und Leipzig, 18-t.

PAget, Gersehishe der Mediein.

Pontsl, Histoire de lantomie et de la Chirurgie. Paris, 1770.

Soltri, Memorials of the c'ruft of simgery in Englend. London, 1886.

SPRENGita, Gischichte der thirurgie. Halle, 1819. 


\section{CON'TENTS.}

\section{CHAPTER I.}

Medieine Among the Ifebrews, the Egrptians, the Orientals, the Chinese,

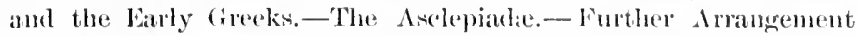

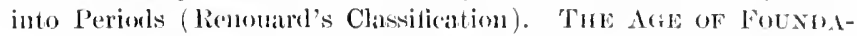
TION.-The Primitive; Sacred, or Mystic: and Philosophic Periols. -Systems in Vogne: Dogmatism, Metholism, Empiricism, Eclecticism,-Hippoerates. . . . . . . . . . . .

PAGE

\section{CIIAPTER II.}

AGE of Foundotion (contiuned).-Anetomir lerion: Influence of the Alexandrian Library. Ilerophihus and Erasistratus. Aretieus. Celsns. Galen.-Empiricism: Asclepiades.-Mcthodism: Themison. - Edeticism. AgE of Transitmox.-Creck Period: Orihasius. Etius. Alexamder of Tralles. Panlus Egrineta.

\section{CHAPTER III.}

Age of Transtaton (eontimued).-Arabic Period: Alkindus. Mesne. Rhazes. Haly-Abbas. Avicema. Albucassis. Avenzoar. Averroc̈s. Maimonides. - School of Sulernum: Comstantinus Afrieanus. Roger of Salerno. Roland of Parma. The Four Masters. John of Procida. . . . . . . . . . . . . . .

\section{CHAPTER IV}

AgE of Transition (coneluded). - The sthool of Montpollier: Raimond Lnlli. Jolm of Gadlesten. Arnold of Villanora. Establishment of Varions Universities. Cerand of Cremona. William of salicet. Lanfrune. Mondino, Guy de Chanliae. Age of Rratoration.Erulite Period, including the Fifteenth and Sixteenth Centuries. Thomas Linacre. Sylvins. Vesalius. Columbus. Eustachius. Fallopius. Fabricius ab Aquapendente. Fabricins Hiklanus.

\section{CHAPTER V.}

Age of Rexoyation (continued).-Endite Period (continued): Benivieni. Jean Fernel. Porta. Severino. Incorporation of Brother- 
hool of st. Côme into the Lniversity of l'aris. Ambroise Paré. Guillemean. Juflucner of the Acrntt Siences: Agriplas. Jerome Cardan. l'aracelsus. Fotal. Joubcrt. . . . . . . . . . 114-147

\section{CIIAPTER VI.}

Age of linovatiox (comtinud).- Student-life During the Fifteenth and sixterenth Conturies. Corenomials Previous to Dissetion.-

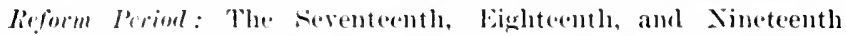
Centuries. Mfolem liealism in Medicine and science. Introdnetion of the Cell-doctrine. 1)iscovery of the Cirenlation. William Inarvey. Malpighi. Leenwenhoek. Correct Insetrine of liespiration. Diseovery of the Iymphatie Cirenlation. The Nervous System. Discovery of Cinchoma. Jevelopment in Olstetric Art, in Medieal Jurispuldence, and in Oral Clinical Traching. Van Helmont.—The Introchemianl systom: Le B̈̈e. Thomas Willis.

\section{CIIATTER VII.}

Are of Rexoratux (rontinued).-Letromechanicel sehool: Santoro. Borelli. Sydenham. Sir Thomas Bowne.-ringery: Denis. F. Collot. Dimis. Baulot (Frime Jneques). Senltems. Rau. Wiseman. Cowper. Sir C. Wren the Discoverer of Hypodermatie Mcdication. Anatomical Discuveries. (ieneral Condition of the Profession During the Neventeenth (entury. The Eighteenth Century. Boerhave. Gaub.-Inimism: Stahl.-Hechanico-elymamic System: Hoftumann. Cullen.-O)d Jienno sheml: Yan Swieten. De Haën._Vitalism: Borden. Erasmus Darwin. . . . . . . 171-202

\section{CHAPTER VIII.}

Ace of liexoyatiox (continum). - Animal Maymatism: Mesmer. Braid. -Brunonimism: John Brown.-Litrtism: Pinel. Hichat. Anenbrugrer. Werlhof. Fank.-Surgery: Petit. lexiult. Scarpa. (iimbernat. Heister. Von Sichold. Richter. Cheselden. Monro (1st). Pott. John Ifunter. 13. Pell, J. Bell, C. Bell. Smellie. Demman. - Retimel of Erperimental study: Haller. Winslöw. Portal. Vieq d'Azyr. Morgagni.-Inoculetion against Small-pox: Lady Montagu. Edwarl Jemner. . . . . . . . . . . . . 203-229

\section{CHAPTER IX.}

Age of Rexoyatiox (rontinued).-The Eighteenth Century; General Considerations. Foundation of Leamed societies, ete. The Royal College of surgeons; the Jus(p)hinum.-The Nineteenth Century Realistie Reaction Against Previous Idealism. Influence of Comte, of Claudle Iirmard, and of Charles Darwin. Influence Exerted by Other sienees.-Theory of Excilement: Roeschlaub. 
-Stimolo and Contrastimolo: lassori.-Momoromethy: Hahmemann.

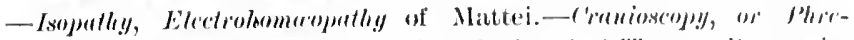

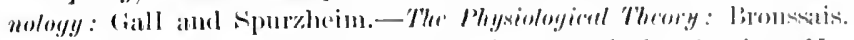
-l'aris f'thological school: Cruveilhier. Andral. Lonis. Mat-

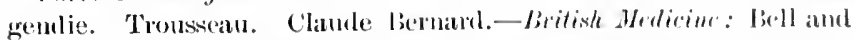

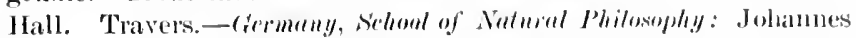

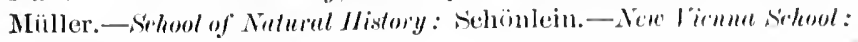

Rokitansky. Skolia.

$230-25: 2$

\section{CHAPTER X.}

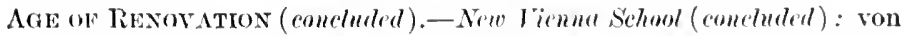
Ifebra. Czermak and Trïrek. Jïgere. Arlt. Gruber. Politzer.-

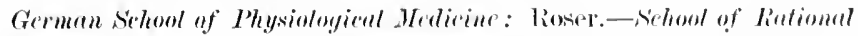

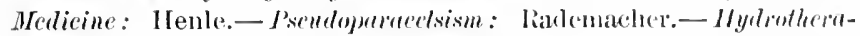

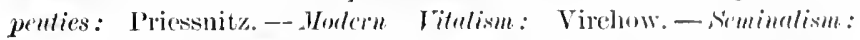
Bonchut. - Puresitism and the Germ-themy: Davaine. I'asteur. Chatreau. Klehs. F. J. Cohn. Koeh. Lister. - Adronecs in

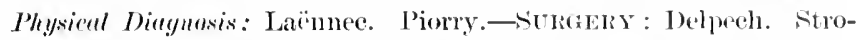
meyer. Sims. Bozeman. Nedowell. Boyer. Larrey. Dnpuytren. Cloquet. Civiale. Vidal. Velpenu. Malgaigne. Nólaton. Sir Astley Cooper. Brodie. Guthrie. Syme. Simpson. Langenheck. Billroth.

\section{CHAPTER XI.}

Histors of Medicine in Anerich. - The Colonial I'lyysicians. Merlieal Study under Preceptors. Inomlation against Simall-pwx. Military Surgery Inring the Revolutionary War. Earliest Metieal Teaching and Teachers in this Comtry. The First Medical Sehools. Benjamin Rush. The First Merlical Jouruals. Irief List of the Best-Knnowu American Plysicians and Surgeons. . . $276-299$

\section{CHAPTER XII.}

The History of Anesthesi A. - Ancesthesia and Analgesia. Dings Possessing Narcotic Properties in nse since Prehistoric Times. Mandragora; Itemp; Hasheesh. Sulphurie Ether and the Men Concerned in its Introtuction as an Anesthetic-Long, Jackson, Wells, and Morton. Morton's First P'ublic Demonstration of the Value of Ether. Norton Entitled to the Creslit of its Introuluetion. Chloroform and Sir James Simpsoir. Cocaine and Karl

Koller. . . . . . . . . . . . . . 300-315

\section{CHAPTER XIII.}

The History of Axtisersis.-Sepsis, Asepsis, and Antisepsis. The Germ-theory of Disease. Gay-Lusste's Researches. Schwann. Tyndall. Pasteur. Davaine. Lord Lister and his Epoch-making 
Revolution in Surgical Methexls. MIolifications of his Earlier Technique without Change in Lnderlying l'rinciples, which still Remain Lnslaken. Changes Efrected in Consequence. Comparison of Old and Moxlerm statistics.

\section{CHAITER NIV.}

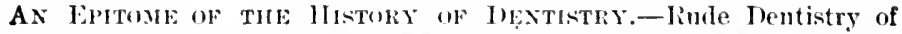
Prehistoric Times. Early Instruments for Extraction Made of leal. Dentistry on the Same Low l'lane as Medicine During the First Half of the Christian Era. Dentistry Tanght at the School of Silermum. l'rogress of the lit on the Continent. P'rosthesis and Substitutes for Homan Teeth. Introbluction of Poreelain for Artificial Terth; of Metal and of Vulcanizul liubluer for Plates; of Plaster for Inypressions. From heing a Trade, Dentistry is now a Profession, in which Americans leat the Worlel. Statistics.

\section{CHAP'l'ER XV.}




\section{LIST' OF ILLUSTRA'TIONS.}

FIA.

PAGP

1. Esculapius, . . . . . . . . . . . . . . . . . . . 7

2. Offering to Asculapins, . . . . . . . . . . . . . . . . . . 9

3. 1lippocrates, . . . . . . . . . . . . . . . . 19

4. Aulus Cormelius Celsus, . . . . . . . . . . . . . . . . . 35

5. The Conversion of Galen, . . . . . . . . . . . . . . . 37

6. Averoës, . . . . . . . . . . . . . . . . . . . . 6 . . .

7. Anmleas Vesalius, . . . . . . . . . . . . . . . . . . . . . . 105

8. Tible-page of The Seven Books of the Anatomy of the ITuman Borly, by Andreas Vesalins, of Brussels, Physician to the Invincible Emperor Charles V,

9. $I V$, Forecjs for Extracting Balls. I, A Dentienlated Form of Foreeps 10x

10. Galniel Fallopins, . . . . . . . . . . . . . . . . 109

11. Forns of Foreps for Enlarging Wrounds, . . . . . . . . . . . . . 111

12. Body thowing Various Kinds of Womnds, . . . . . . . . . . . . 117

13. Morle of Extracting Lealen Bullets, . . . . . . . . . . . . . . 1:1

14. Ambroise l'aré, . . . . . . . . . . . . . . . 124

15. Plicrs, Iron for Actual Cantery, and Seton-ncedles, . . . . . 126

16. Swan's Beak, Used for Dilating the Track of a Wound and Extracting a Foreign Borly,

17. Various Instrunents for the Extraction of Balls, . . . . . . . . . . 1:31

18. Speculums for the Mouth and Womb, ete., . . . . . . . . . . . 13:;

19. Amputation Instruments, . . . . . . . . . . . . . . . . . 13;

20. Diflerent Forms of Trephines and Pliers, . . . . . . . . . . . . . 137

21. Philip Theoplnastus Paracelsus, . . . . . . . . . . . . . . 14:3

2:. William Harvey, M.D., . . . . . . . . . . . . . . . . . . . 156

23. Thomas Eylenham, . . . . . . . . . . . . . . . . 173

24. Straiglit Saws and Divers Scraping Tools, Wherewith the Skull, Being liotten or Having a Fissure, is Scruped Away, . . . . . . . 179

25. Surqieal Treatment of Certain Dislocations, . . . . . . . . . . . 1 1

26. Tarious Operations on the Arms and Lower Limbs, . . . . . . . . . 185

27. Surgical Operations on the Blcast, etc., . . . . . . . . . . . . . . 187

28. Boerlaave, . . . . . . . . . . . . . . . . . . . 193

29. John Brown, M.D., . . . . . . . . . . . . . . . . . . . 20,

30. Ph. Pinel, . . . . . . . . . . . . . . . 207

31. Marie François Xavier Bichat, M.D., . . . . . . . . . . . . 208

32. Willian Hunter, M.D., F.R.S., . . . • . . . . . . . . . 217

33. John Hunter, . . . . . . . . . . . . . . . . . . 218

34. J. F. Blumenbach, . . . . . . . . . . . . . . . . . 223

35. Edward Jemmer, M.I., . . . . . . . . . . . . . . . . . 227

36. Samnel Hahmemann, . . . . . . . . . . . . . . . . . . 242

37. Rudolph Virchow, . . . . . . . . . . . . . . . . . . 257

38. Bernhard von Langenbeck, . . . . . . . . . . . . . . . . 265

39. Theodor Billroth, . . . . . . . . . . . . . . . . . . . 266 
FIG.

40. Nir Astley Cooper, Bart., . . . . . . . . . . . . . . 272

41. Sir lenjannin Collins likrlie, Bart., F.K.S., . . . . . . . . . 2 273

1:. 13. Waterhonse, II.1),

4:3. Surgeon's Jiall, next to Philarlelphia Dispensary, Fifth street below

Liblary street, . . . . . . . . . . . . 281

11. Renjanin linh, .1., . . . . . . . . . . . . . 284

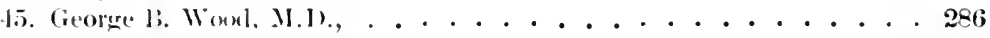

46. Jiobley Dnuglison, M.I., . . . . . . . . . . . . . 287

47. Austin Flint, Y.J., . . . . . . . . . . . . . $28 R$

4R. John lay M.D. . . . . . . . . . . . . . . . 289

49. I'hilip Syng l'hysick, M.D., . . . . . . . . . . . 291

j). Ephrain IClhivell, M.I., . . . . . . . . . . . . 292

51. S. I). Gross, MI.I., LL.I., . . . . . . . . . . . . 294

52. J. Marion sims, М.П., . . . . . . . . . . . 296

5:. I. Haves Agnew, M.D., LL.D., . . . . . . . . . . . . . . 297

54. William T. (r. Morton, M.I)., . . . . . . . . . . . . . . 307

55. Dr. Morton Making the First Publie Denonstration of Etherization at the Massachusetts General IInspitaI surrounded by the Medical Staff of that Institution, Oetoher $16,1846, \quad$. . . . . . . 309

56. Lord Lister, M.D., D.C.L., LL.D., P.R.S., . . . . . . . . . . . 323 


\section{An Epitome of the History of Medicine.}

\section{CIIAP'TER I.}

Medieine Among the Ilebrews, the Eryptians, the Orientals, the Chinese, and the latrly Greeks.-The Aselepiadie.-Further Arrangement into P'eriods (Renouarl's Classitication).

The Aar of Fouxidun.-The Primitive; Sacred, or Mystie ; and I'hilosophic Periols.--irstems in Vogne: Iogmatism, Metholism, Empiricism, Eclecticism.--Hipworates, born 160 13.c.

Or the origin of medicine but little need be said by way of preface, save that it must have been nearly contemporaneous with the origin of cirilization. 'The lower animals when sick or wounded instinctively lessen or alter their diet, seek sechusion and rest, and even in certain cases seck out some particular herb or healing substance. Thus, too, does the savage in lis primitive state; and experience and superstition together lave led nearly all the savage tribes into certain labbits and forms in case of injury or discase. For us the history of medicine must necessarily begin with the written history of events, and its earliest endearors need detain us but a rery short time. Its earliest period is enreloped in profound obscurity, and so mingled with myth and fable as to be very uncertain. It embraces an indefinite time, during which modicine was not a science, but an undigested collection of experimental notions,vaguely described, disfigured by tradition, and often made inutile by superstition and ignorance. Among the carliest records of probable anthenticity are perhaps the Scriptures, from which may be gathered here and there a fair notion of Egyptian knowledge and practice. Thus we read that Joseph commanded his servants and physicians to embalm him, this being about 1700 B.c. It shows that Egypt at that time possessed a class of men who practiced 
the healing art, and that they also cmbalmed the dead, which must have both required and furnished a crude idea of general anatomy. We are also informed from other sourees that so superstitions were the Egyptians that they not only scofted at, but would stone, the embalmers, for whom they had sent, after the completion of their task. 'The probably mythical being whom the Egrptians called Thoth, whom the Greeks named IVermes and the Latins Mereury, passed among the Egyptians as the inventor of all sciences and arts. 'To him ale attributed an enormous number of writines conceming all subjects. Some have considered him as identical with Bacchus, Koroaster, Osiris, Isis, Serapis, Apollo, and cren Shem, the son of Noah. Others have thonght him to be a gool. It is now almost certain that the books attributed to Hermes were not the work of any one hand or of any one age. 'The last six volumes of the forty-two composing the encrelopedia, with which Ilermes is crediter, refer to medicine, and embrace a body of doctrines firly complete and woll arranged. Of these six, the first treats of anatomy; the sccond, of diseases; the thind, of instruments; the fourth, of remedies; the fifth, of discases of the eve; and the sixth, of diseases of women. In completeness and arrangement it rivals, if not smpasses, the Ilippocratic collection, which it antedated by perhaps a thonsand years. The Egrptians appear at first to have exposed their sick in public (at least. so says Strabo), so that if any of those who passed by lad been similarly attacked they might wive their advice for the benefit of the sufferers. In fact, according to Herorlotus, the same custom prevailed among the Babylonians and lusitanians. At a later date all who were thus cured were required to go to the temples and there inscribe their symptoms and what had belped them. 'The temples of Camopus and Vulcan at Memplis became the principal depots for these records, which were liept as carefully as were the archives of the nation, and were open 
for public reference. These records, being under the control of the priests, were mainly studied by them, who later collected a great mass of fiacts of more or less importance, and endeavored to found upon the knowledge thus collected an exchisive practice of the art of medicine. In this way they formed their medical code, which was called by Diodorus the IFiera Biblos, Secered Booli, from whose directions they were never allowed to swerve. It wals perhaps this code which was later attributed to IIermes, and that made up the collection spolien of by C'lement of Alexandria. If in following these rules they could not save their patients they were held blameless, lnt were punished with death if any departure from them were not followed by success.

I have spoken of embalming as practiced by the Egyptians. It was of three grades: the first reserved for men of position and means, which cost one talent, and according to which the brain was remored by an opening through the nasal fosse, and the intestines through an opening on the left side of the ablomen, after which both cavities were stuffed with spices and alromaties; then the body was washed and spread orer with gum and wrapped in bandages of linen. The second grade was adopted by families of moderate means; and the third was resorted to by the poor, consisting simply in the washing of the body and maceration in lye for seventy days.

Pliny assures us that the kings of Fegpt permitted the opening of corpses for the purpose of discovering the canses of discase, but this was only permitted by the Ptolemies, under whose reign anatomy was carried to a very high degree of cultivation. The papreri discovered recently by Ebers depict the time of Rameses II.

The medicine of the Hebrews is known generally through the sacred seriptures, especially through the writings attributed to Moses, which embraced rules of the highest sagacity; especially in public hygiene. The book of 
Leviticus is largely made up of rules concerning matters of public health. In the eleventh chapter, for instance, meat of the rabbit and the hog is proscribed, as apparently injurious in the climate of Egypt and India; it, however, has been suggested that there was such rariation of names or interpretation thereof as to make it possible that our rabbit and hog are not the animals alluded to by Moses. 'The twelfth and fifteenth chapters of the same book were designed to regulate the relation of man and wife and the purification of women, their outlines being still observed in some localities by certain sects, while the hygienic measure of circumcision then insisted upon is still observed as a religions rite among the descendants of Moses. For the prevention of the spread of leprosy, the measures suggested by Moses could not now be surpassed, although ancient anthors have confounded under this name divers affections, probably including syphilis, to which, however, the same hrgienic rules should apply. Next to Moses in medical lore should be mentioned Solomon, to whom is attributed a very high dearee of linowledge of natural history, and who, Josephus elaimed, had such perfect linowledge of the properties of all the productions of natme that he availed himself of it to compound remedies extremely useful, some of which had even the rirtues necessary to cast ont devils.

The most conspicuons feature in the life of the Indian races is their division into castes, of which the most noble is that of the priests, or Brahmins, who in ancient times alone hatd the privilege of practicing medicine. Their Organon of Medicine, or collection of medical knowledge, was a book which they called Tagadasustir. It was not systematically armuged, and in it demonology played a large rôle. They held the human body to consist of 100,000 parts, of which 17,000 were vessels, each one of which was composed of seren tubes, giving passage to ten species of gases, which by their conflicts engendered a number of dis- 
eases. 'I'hey placed the origin of the pulse in a reservoil located behind the umbilicus. 'This was four fingers wide by two long, and divided into 72,000 canals, distributed to all parts of the body. 'The plysician examined not only the pulse of his patient, but the dejecta, consulterl the stars, the thight of birds, noted any incidental oecurrence during his visits, and made up his prognosis from a multifude of varying cirenmstances, omitring only those which were really valuable, namely, the symptoms indiating the state of the organs. Ancient Hindoo charlatan priests let fall from the end of a straw a diop of oil into the patient's water. If the oil was precipitated and attached itself to the bottom of the vessel, they predicted an unfarorable result; it, on the contrary, it Hoated, they gave a faromble prognosis. 'This is, so far as we know, the carliest recorded way of testing the specific grarity of the mine.

With all their absurdities, however, the Indians appear to have done some things that we scarcely do to-day: they are said to have had an ointment that caused the cicatrices of variola to disappear, and they cured the bites of venomous serpents with remedies whose composition has becn lost.

The antiquity of the Chinese is simply lost in tradition and fable. From time inmemorial their rulers have taken extraordinary care to prevent contact and interchange of ideas with foreigners. For 4000 years their manners, laws, religious beliefs, language, and teritory have scarcely changed. In this respert they stand alone among the nations of the earth. They attribute the invention of medicine to one of their emperors named II wang-ti, who was the third of the first dynasty, and whose supposititions date is 2687 B.c. He is considered to be the author of the work which still serves them as a medical guide. It is, however, more probably an apocryphal book. Its philosoply was of a sphygmic kind,-i.e., based upon the pulse, which they 
divided into the supreme or celestial, the midlle, and the inferior or terestrial; by the examination of which the Chinese physician was supposed not only to show the seat of discase, but to judge of its duration and grasity. It is related that one of the ancient Chinese emperor's directed the dead bodies of eriminals to be opened, but this is questionable, since it is rertain that they lave the most profound ignorance of rudimentary anatomy, and glaning errors abound in their system. Being thus replete with errors, and possessing $n 0$ anatomical knowledge, their surgery was of the most barbarous type. So one dared attempt a bloody operation; the reduction of hemia was mhluown; a cataract was regarded as beyond their resources; and eren venesection was nerer practiced. On the other hand, they cmployed cups, and acupancture, fomentation, plasters of all kinds, lotions, and baths. The moxa, or red-hot button, was in constant use, and they had their magnetizers, who appear to have been convulsionists. For a long time there existed at Pelin an Imperial School of Medicine, but now there is no such organization nor any regulation for the privilege of practicing melieine or surgery since 1792 . At least until lately the comntry and the cities were infosted witl quacks, who dealt out poison and death with impunity. 'lhey practiced most murderous methods in place of the principles of midwifery. Only since the cirilized missionaries lave penetrated into their comntry has there been any improvement in this condition of affairs.

It is Greece which furnishes us with the most interesting and the most signifieant remains of the history of medicine during antiquity, as she fumishes every other art with the same historical advantages. During the period preceding the 'Trojan War there is little but mytl and tradition. Ieclerc catalogued some thirty divinities, heroes or heroines, who were supposed to have invented or cultivated some of the branches of medicine. Melampus is 
perhaps the first of these who immortalized himself by extraordinary cures, especially on the daughters of Proetus, King of Argos. 'These young princesses, haring taken rows of celibacy, became subjects of hysterical monomania, with delusions, during which they imagined thementes transformed into cows and roamed the forests instead of the palaces. This nerrous delusion spread to and involved many other women, and became a serious matter.

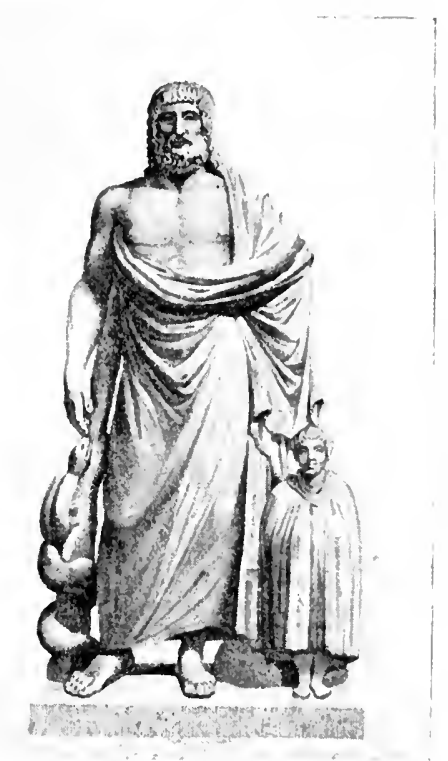

FIG. 1.-Ascthapits.

(From a steel engraving of the marlle statue in the Louvre.)

Melampus, the shepherd, having olserved the purgative effects upon goats of white hellebore, gave to the young women milk in which this plant had been steeped, thereby spcedily effecting a cure. Scarcely less distinguished than Melampus was Chiron. He was mainly distinguished because he was the preceptor of Esculapins, the most eminent of early Grecks in this field. By some Esculapius was considered the son of Apollo by the nymph Coronis, 
Sereral cities of Greece contended for the honor of his birthplace, as they did for that of Homer. That he was famous at the time of the Argonantic expedition is seen by the fict that the twins ('astor and Pollux desired him to accompany the expedition as surgeon. Be his origin what it mar, Asculapins was the leading character in medicine of all the ancients, with the possible exception of Hermes among the Egyptians; in fiat, some, scholars consider the two identical. 'lemples ware erected in his honor, priests were consecrated to them, and schools of instruction were thre established. It is related that l'nuto, god of hell, alarmed at the diminishing number of his daily arrivals, complained to Jupiter, who destroyed the andacions healer -on which accomnt, some wit has said, "the modern children of . Ecculapius abstain from performing prodigies." But the true Esculapians, the successors of the demigod, were imitated or copied by the crowd of charlatans and quacks, calling themsclves theosophs, thaumaturgs, and so on, and not alone at that date, but for generations and centuries therafter, Paracelsus and Mesmer being fair examples of this class. The poet P'indar, who lived seven or cight humdred years alter Esculapins, says that he cured ulcers, womds, fiver, and pain of all who applied to him by enchantment, potions, incisions, and by external applications. ${ }^{3}$

The followers of Exculapins, and the priests in the temples dedicated to him, soon formed a scparate caste, transmitting from one to another, as a family heritage, their medical knowledge. At first no one was almitted to practice the sacred science unless he joined the priesthood, although later this secreey was relaxed. 'l'hey initiated strangers, provided they fulfilled the test which they made. Some lind of medical instruction was given in each temple. The three most celebrated temples to Esculapius were that of Rhodes, already extinct by the time of Hippocrates;

'Thind Pythiau Ode. 
that of Cnichs, which published a small repertory; and finally that of Cos, most celebrated of all, becanse: of the illustrious men who emanated from this school. In thene temples votive tablets were fastened in large mumbers, alter the fashion of the Egyptians, the same giving the name of the patient, his affliction, and the manner of his cure. For example, such a one as this: "Julien romited blood, and appeared lost beyond recovery. 'The oracle ordered him to

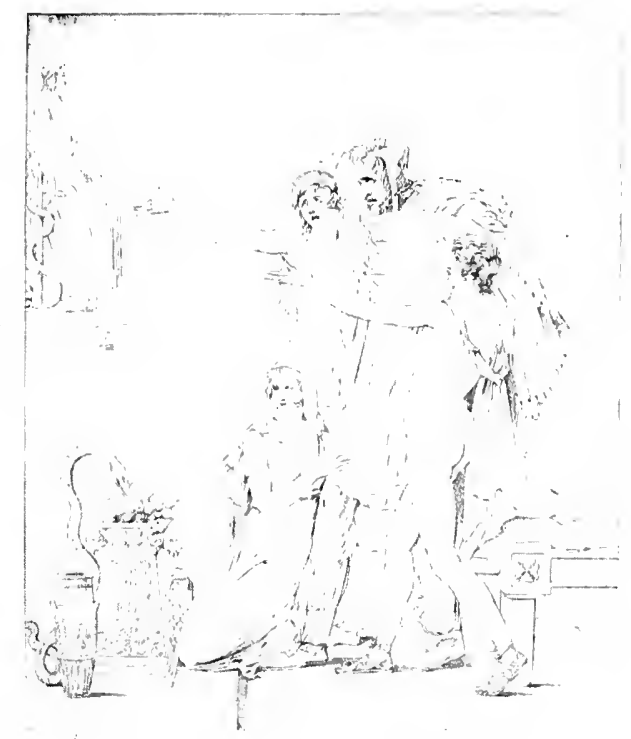

Fig. 2.-OFFERIxg to Asculapits.

(From an engraving by George Conke of a painting by Guérin.)

take the pine-secds from the altar, which they had three days mingled with honey; he did so, and was cured. Having solemmly thanked the god. he went away." There is reason to think that the priests of these temples made for their own uses much more minute and accurate accounts, which should be of some real service. since the writings which have come down to us erince a habit of close observation and clear description of disease. During the Trojan 
War two men are frequently mentioned by Homer as possescing great surgical skill. These were Mfechen and Porlellivins. They were regareled as sons of Esculapius, the former being the elder. The first account of renesection, although not anthentic. refers to the bleeding practiced by the litter upon the danghter of the King of Caria, upon whose shores Podalirins was cast by tempest after the ruin of l'riam's kingrlom. Whether lie was the first of all men to practice it or not, it is certain that the act of renesection goes back long prior to the era of Hippocrates, who speaks of it an frequently performed.

Nany of the deities upon Olympus seem at one time or another to have usurped medical functions. Apollo, the reputed tither of Eculapins. appropriated nearly everything under the name of Pieon, who assumed the privilege of exciting or subduing epidemics. Juno was supposed to preside at acconchements, and in both the Iliad and Odyssey it is indicated that Apollo was considered as the canse of all the natumal deaths among men, and Diana of those among women.

The long Trojan War appears to have been an epoch. making event in the modical and surwical history of those times, ans was the Civil War recently in our comntry. Certain vague and indefinite practices then took more fixed form. and from that time on medicine may be said to have been fimished with a history. After the dethronement of Priam and the destruction of his capital, navigation was free and minestricted. The II.llenists covered with their colonies both shores of the Mediteramean, and their navieratore cren pawed the pillars of Hercules. Bry these means the worship of Ecculapius passed from Greece into what is now Asia, Africil. and Italy. In his temple at Epidaurus was a statue of colossal size made of gold and irory. The dialognes of Plato. especially the Phredo, make it apparent that the cock was the animal sacrificed to him, and hence sacred to the grod of medicine. The priests attached 
to his worship, were called Asclepiudre, or descendants of Esculapius. The temples were usually hygienically located near thermal springs or fountains and among groves. Pilgrimages were made from all quarters, and these localities became veritable health-resorts. A wellregulated dietary, pure air, temperate habits, and finth stimulated to a fonatical degree combined and sufficed for cures which even nowalays would be reganded as wonderful. The priests prescribed renesection, purgatives, emetics, friction, sea-baths, and mineral waters, as they appeared to be indicated. The imagination of the patient was contimually stimulated, and at the same time controlled. Before interrogating the oracles they must be purified by abstinence, prayer, and sacrifice. Sometimes they were obliged to lie in the temple for one or more nights. The gods sometimes revealed themselves in mysterious ways, at times devonring the cakes upon the altars mider the guise of a serpent, or again causing dreams which were to be interpreted by the priests. There can be no doubt that sometimes, at least, the grossest frands and the basest trickery were relied upon for the purpose of impressing the minds of those weakened by abstinence or influenced by drugs. Mercenary considerations were not lacking; moreover, cures were often not obtained mitil zeal had been redoubled by largely increased contributions to the treasury of the temples. In the neighborhood of many of these temples serpents abounded, non-renomons and easily tamed. These were employed by the priests in rarious supernatural performances by which the ignorant people were astonished and profoundly impressed. In fact, the serpent and the serpent-myth played a very large rôle in the early listory of medicine as well as that of religion and religion: symbolism.

It will thus be seen that during the space of about 706 years medicine underwent a transformation in Greece. It was first domestic and popular, practiced by shepherds, 
soldiers, and others; then became sacerdotal; after the Trojan $\mathrm{W}_{\mathrm{a}}$ it was confined to the vicinity of the temples and practiced in the name of some divinity; and finally it was wrapped in mystery and mystic symbolism, where superstition was played upon and credulity made to pay its reward. Down to the time of Hippocrates the Asclepiatie rendered some genuine service to science, especially by inculcating habits of observation, in which IIippocrates excelled above all. Liter, however, down to the time of the Christian era, medicine in the temples dechined, and bectme, in fact, a system based upon the grossest jugrglery.

It is time now that we malie a systematic attempt to classify events in the history of medicine, and to recognize certain distinct epoehs as they have occurred. For this purpose I know of no better arrangement than that of Renonard, which, in the main, I shall follow, at least during the forepart of this book. In this sense lie divides the past into three ages, lnown, respectively, as the Age of Foundution, the Age of Tramsition, and the Age of Renovation. Fach of these chronological divisions is subdivided into periods, of which the first contains four:-

Age of Foundation.-1. 'The Primitice Period, or that of Instinct, heginning with myth, and ending with the destruction of 'Troy 1184 years before C'hrist.

2. The Sucred, or Mystic, Period, ending with the dispersion of the Pythagorean Society, 500 years before C'lirivt.

3. The Philosophic Period, terminating with the foundation of the Alexindrian library, 320 years before Christ.

4. 'The Alurtomic Period, ending with the death of ualeus shont A.D, 200.

The Second Age. or that of 'Transition, is divided into a fith. or Greel: Period. ending at the buming of the Alexandrian library, A.D. 640, and a sixth, Arabic Period, ending with the revival of letters, A.D. 1400 . 
The 'Thind Age, or that of Renovation, includes the seventh, or Erudite Period, comprising the fiftecnth and sixteenth centuries, and eighth, or Reform Periorl, comprising the seventeenth, eighteenth, and nineteenth centuries.

Examining this table for a moment, it will be seen that so far we have dealt with the l'rimitive period and the Sacred, or Mystic, Period. Before passing on to the Plitosophic Period let us for a moment follow Renonard, who likens the three sehools of medical belief in the earlier part of the Primary Age, or the Age of Foundation, to the three schools of cosmogony, which obtained among the Greeks. The first of these was headed by Pythagoras, who regarded the universe as inhabited by acknowledect sentient principles which gorcrned all substances in a determined way for preconceived purposes. Animals, plants, and even minerals were supposed to possess vivifying spirits, and above them all was a supreme principle. 'T'o this sehool corresponded the so-called Dogmatic Sctiool of medicine, attributed to Hippocrates, which was the precursor of modern vitalism, and regarded diseases as indivisible units from beginming to termination; in other words, they consisted of a regular programme of characteristic systems, successive periods, and of long course, either for the better or worse; that was one of the eharacteristie dogmas of the Hippocratic teaching. The Second System of cosmogony was that founded by I eucippus and Democritus, who explained all natural phenomena without recourse to the intervention of intelligent principles. All things for them existed as the necessary result of the etemal laws of matter. They denied preconceived purposes and ridiculed final canses. To this system corresponded that in medicine which has been termed Methodism (medically and literally speaking) and which recognized as its founders Esculapins and 'Themison. The believers in this doctrine attempted to apply the atomic theory of Democ- 
ritus and Fipicuns to the theory and practice of medicine. Atoms of rallons size were supposed to pass and repats without resition thromble carities or pores in the human body. So long as the atoms and pores maintained a normal relationship of size and proportion health was maintained, but it was deranged so soon as the exactuess of thene rekations wats destroyed or interfered with. The Domatists consilered vital reaction as a primary phenomconom. While with the Methodists it was secondary. The Third system of asmogony, fomded by Parmenides and Pyrho, believed in the matmal improvement of bodies in their emdless reproduction and chanese, and conchuded that wiedom consisted in remaining in doubt; in other words, thry were the annosties of that day. "What is the use," said they, "of fatiguing the mind in endearonge to comprehem! what is beyond its apability?" Iater they were known as Slieptics and \%etetics, to indicate that they were always in seareh of truth without flattering themselves that they had fommel it. 'To them comesponded a third chass of phesicians, with Philinus and Serapis at their head, who deemed that proximate canses and primitive plienomena of disease were inacessible to observation; that all that is affirmed on these subjects is purely hypothetical, and hence mowerthy of eomsideration in choosing treatment. For them objective symptoms-or, as we would say, signscomstituted the matumal history of disease, they thus believing that their remedios conld only be sugrgested by experience, since nothing alse conld reval itself to them. 'Thery therefore took the name of Empirics.

Finally a fouth class of physicians arose who would not adopt any one of these systems exchusirely, but chose from calch what socmed to them most reasonable and satisfactory. 'They called themselves Eclectics, wishing thereby to imply that they made rational choice of what seemed best. 'The ilca conreyed in the term "eclecticism" has been farly criticised for this reason: eclecticism is in reality 
neither a system nor a theory; it is individual protrusion elevated to the dignity of dogma. 'The true exelectic recosenizes no other rule than his particular taste, reason, or fincre, and two or more eclectics have little or nothing in common. If that were true two thousand rears ago, it is not much less so to-day. 'The eclectic carefully avoids the discussion of principles, and has neither taste nor caparcity for abstract reasoning, aithough he may be a good practitioner; not that he has no ideas, but that his ideas form no working system. With him medical tact-i.e., cultivated instinct -replaces principle.

'The eclectic of our day, however, is only an (mpuric in disguise, - that is, a man whose opinions are based on comparison of observed facts, but whose theoretical idcas do not go beyond phenomena.

In older days philosophy embraced the whole of human knowledge, and the plibosopher was not permitted to be unacquanted with any of its branches. Now physics, metaphysies, natural history, ete, are aranged into separate sciences, and the sum-total of knowledge is too great to be compassed by any one man.

Pythagoras was the last of the Greek sages who made use of hieroglyphic witings and transmitted his doctrine in ancient language. Born at Samos, he was, first of all, an athlete; but one day, haming a lecture on immortality of the soul, he was thereby so strongly attracted to philosophy that he renomiced all other oceupation to derote himself to it. ILe studied arduously in Fgypt, in Phoenicia, in Chaldea, and even, it is sald. in India, where he was initiated into the secrets of the Bralmins and Magi. Finally, retuming to his own comtry, he was received by the tyrant Polycrates, but not made to feel at home. Starting on his travels again, he assisted at one of the Olympic games. and, being recognized, was warmly greeted. He sailed to the south of Italy, landed at Crotona, and lodged with Milo, the athlete. Commenc- 
ing here his lectures, he soon gathered around him a great number of disciples, of whom he required a very severe novitiate, lasting eren five or six years, during which they had to abstain almost cutirely from conversation, and live upon a very fingal diet. Those only who persevered were initiated later into the mysteries of the order. Ifis disciples had for him most profomel rencration, and were accustomed to decide all disputes with: "lhe master has said it." Pythagolas possessed immense lnowledge; he invented the theorem of the square of the hypothemuse, and he first divided the gear into 365 days and 6 homs. He secms to have suspected the movements of our planetary system. He traveled from place to place, and founded schools and communities whorever he went, which exercised, at least at first, only the happiest influence; but the snceess and inthence which their leaning gave them later made his disciples bold, and then dishonest, and his commumities were finally dispersed by angry mobs, which forced their members to conceal or expatriate themselves; and so, even during the life-time of its founder, the Pythagorean Society was destroyed, and nerer reconstructed.

With Pythagoras and his disciples numbers played a very important rôle, and the so-ealled language of numbers was first taught by him. He comsidered the mit as the esential principle of all things. and designated God by the figme 1 and matter by the figme 2 , and then he expresied the universe by 12, as representing the juxtaposition of 1 and 2 . As 12 results fiom multiplying 3 by 4 , he conceived the miverse as composed of thee distinct worlds, airh of which was developed in four concentric spleres, and these splieres corresponded to the primitive elements of fire, air, earth, and water. The application of the number 12 to express the mirerse Pythagoras had received from the Chaldeans and Figrptians-it heing the origin of the institution of the zodiac. Although this is digressing, it serves to show what enormons importance the people of 
that time attached to numbers, especially to the temary and quartenary periods in the determination of critical days in ilhess. Pythagoras was the founder of a philosophic system of great grandeur, beauty, and, in one sense, completion, embrineing, as it does, and nuiting by common bounds God, the miverse, time, and eternity ; fumishing an explanation of all natural phenomena, which, if not true, was at that time acceptable, and which appears in strong and favorable contrast as against the mythological systems of paran priests. No wonder that it captivated the imagination and understanding of the thinking young men of that day. Had they continured in the original purity of life and thought in which he indoctrinated them there is no knowing how long the Pythagorean school might have continued. But after it had been dissolved by the storm of persecution, its members were scattered all over Greece and even beyond. Now no longer held by any bonds, many of them revealed the secrets of their doctrine, to which circumstance we owe the little knowledge thereof we now possess.

The Pythagoreans apparently first introduced the custom of visiting patients in their own homes, and they went from city to city and house to house in performance of this duty. On this account they were called Periodic or Ambulant physieians, in opposition to the Aselepiadre, who prescribed only in the temples. Fmpedocles, of Agrigentum, well known in the history of philosophy, was perlaps the most famous of these physicians. Let the following inciclent witness his sagacity: Pestilential ferers periodically ravaged his native eity. He observed that their appearance coincided with the return of the siroceo, which blows in Sicily on its western side. He therefore advised to close by a wall, as by a clam, the narrow gorge from which this wind blew upon Agrigentum. His advice was followed and his city was made fiee from the pestilence.

Again, the inhabitants of Selinus were ravaged by 
epidemic disease. A slugrgish stream filled the city with stalnalut water fom which mephitic rapors alose. Eme pedocles atused two small rivulets to be couducted into it, which made its rument more rapid; the noxious vapors

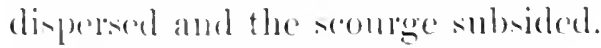

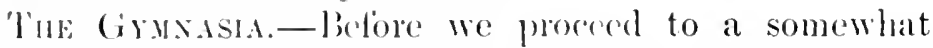
more detailed. but brinf". areount of Hippocrates, it is necessary to say a word or two of the ancient grmasia of Gresere. which wore used long before the Asclepiadse had practiced or begm to teach. In these grmmasia were three order of phyicians: first, the director. alled the Gymnersinet ; second. the subdirector, or Gymmast, who directed the pharmacentical treatmont of the sick; and, lantly, the Latioliptes. who put up prescriptions, anointed, bled, gave massige, dressed wommds and uleers, reduced dislocations, treated absesses. ete. Of the grmmasiarchs wonderfin stories are told evincing their sagacity, which, though somewhat falmbous. indicate the possession of a very high dongee of skill of a certain kind. Of one of the most colebrated of these. Herodicus, we may recall l'lato's accusation, who reprimanded him severely for succeding too well in prolonging the lives of the aged. Whatever else may he said. we must acknowledge that above all others the (ivereks recondized the value of physical culture in the prevention of intirmity, and of all physical methods in the troatment of discase. By their wise enactments with reference to these matters they set an example which molern lexislators have rarely. if ever, becn wise enomgh to follow.-in example of compulsory physical training for the gomne-and thereby built a prople of rugged constitution among whom discase was almost nuknown.

I come now to the so-called Philosophic Periorl. or the thind prediod in the Age of Fomblation, which is inseparably commected with the name of Hippocrates. This central figme in the history of ancient medicine was born on the 
Island of Cos, of a fimily in which the practice of medicine was hereditary, who traced their ancestors on the mate side to Asculapins, and on the female side to Hereules. The individual to whom every one refers muder this name was the second of seven; the date of his birth goes back ta) 460 B.c., but of his life and his age at death we know little; it is supposed generally that he died B.C. 377, at the? age of 83. It is certain that he travelerl widely, since his

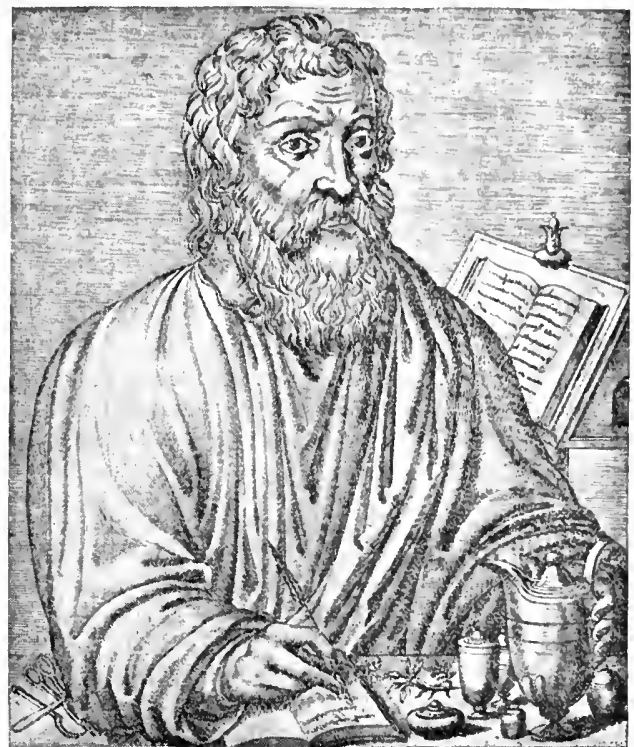

Fig, 3,-Hiprocrates.

writings evince the knowledge thus gained. He was a contemporary of Socrates, although somewhat younger, and lived in the age of Pericles, - the golden age for science and art in Greece.

'The Island of Cos is now called Stan-Co, and is situated not firr from the coast of Ionia. Formerly it was considered as having a most salubrious climate; now that it is under the dominion of the Turks, it is considered most unhealthy. It possessed a temple dedicated to Esculapius 
and a celebrated medical school. But Mippocrates, not satistied with what he could learn here, visited the principal foreign cities, and seems to have been a most accurate and painstaking observer and collector of notes. 'That he achieved great renown in his life is known, since Plato and cren Aristotle refer to him as their anthority in very many mitters. Ilis childen and grandehildren followed in his footsteps, and published their writings under the same name; it has, therefore, become diffirnt to distinguish his works from theirs. Finally, anthors more unscrupulous, who bore no relationship to him. attached his name to their own writings. But the true were, as a rule, easily distinguished from the spurious, and were carefully separated by those in charge of the Alexandrian library.

'The enumeration of his witings by different anthors varies very much. Renouard, who soems to have studied the subject very earefully. gives the following as appearing to him to be the anthentic list of witings of Hippocrates the Second,-i.e., the Great: 'The Progmostie, the Apliorisms, the first and third books of Epidemics, that on Regimen in Acute Disease, that on Airs, Thaters, and Places, that on Articulations and Luxations, that on Fractures, and the Morlile, or the treatise on instruments and reduction. This list does not comprise the fourth part of the entire Iippocatic collection, but its authenticity appoars to be mudoubted, and it suffices, as Renomarel says, to justify the enthusiasm of his contemporaries and the admination of posterity. Iater, joined with the writings of Pythagoras, Plato. Aristotle, and others, they constituted the so-called Hipporatic collection. which was a definite part of the great libraries of Alexandria and Pergamos, and formed the most ancient authentic moumment of medical science.

Respect for the bodies of the dead was a religions observance in all Girece, and prevented the dissection of the hunan body. Consequently the knowledge of anatomy possessed by Hippocrates must have been meagre. Never- 
theless, he describer lesions, like wounds of the head, of the heart, the glands, the nature of bones, ete. It being impossible to establish a physiology withont an anatomical basis, it is not strange that we find but little physiologry in the Hippocratic writings, and that this little is very crucle and incorrect. Arteries and reins were confonnded, and nerves, tendons, ligaments, and membranes were represented as analogons or interchangeable tissues. The physiologists of those days abandoned themselves to transcendental speculation concerning the nature and principles of life, which some placed in moisture, others in fire, etc. Speculation, thus run wild, prevented such accurate observation as might have greatly enlanced the progress of physiological knowledge.

Hippocrates wrote at least three treatises concerning hygiene: The first, on Airs, Waters, and Places; the second, on Regimen; the third, on Srlubrious Diet,practically an abridgement of the preceding, in which he recommends the habit of taking one or two vomits systematically every month. The classification of diseases into internal or medical, and external or surgical, is not modern, but is due to Hippocrates; neither is it philosophic, although it is very convenient.

With so little knowledge of physiology and pathology as the ancients had, it is not strange that they ascribed undue inportance to external appearance; in other words, to what has been termed semeiotics, which occupies a very considerable place in the medical treatises of the Asclepinde. Indeed, the writings on this subject constitute more than one-eighth part of the entire Hippocratic collection. To prognosis, also, Hippocrates ascribed very great importance, saying that "The best physician is the one who is able to establish a prognosis, penetrating and exposing first of all, at the bedside, the present, the past, and the future of his patients, and adding what they omit in their statements. He gains their confidence, and being 
eonvinced of his superiority of linowledge they do not hesitate to commit themselves entirely into his hands. He (an treat, also, so much better their present condition in proportion as he shall be able from it to foresee the fiuture," este.

'Th the careful scrutiny of facial appearances, the position. and other body-marlis about the patient he attributed very ereat importance; in fact. so positive was he about these matters that he embodied the principal rules of semciotics into aphorisms, to which. however, there came later so many exceptions that they lost much of their value. From certain passages in his hook on Piediction, and from the book on Treetment, which is a part of the Hipporatio collection, it appears that it was the eustom then of physicians to annomee the probable issue of the divense nom the first or second risit, - a custom which still preails in China and in Turker. It gave the medical man the dignity of an oracle when right, but left him in a rery awkward position when wrong.

Tho Hippocrates we are indebted for the classification of sporadic. cpiclemic, and endemic forms, as well as for the division of discase into acute and chronic. Hippocrates wrote extenvirely on internal disease, inchuding some particular forms of it. such as epilepsy, which was called the sarced discase; also fragments on diseases of girls, relating particularly to hysteria ; also a book on the nature of woman, an extensive treatise on diseases of women, and a monograph on sterility. That Ilippocrates was a remarkahly rlose observer of disease as it appeared to him his books amply prove; in fict, they almost make one think that close observation is one of the lost arts, being only open to the objection that too much weight was attached to insignificant exterual appearances, speculation on which detracted from consideration of the serions feature of the case. Itis therapenties, considering the crude information of the time, was a rast improvement on that which had 
preceded, and really entitled him to his title of "Girmat Pliysiciall."

Of extermal diseases and their surgical therapention he wrote fully: on The Laboratory of the Surgeon, dealing with dressings, bandagring, and operating; on Fracheres; and on Articulations and Dislocetions, showing nund more anatomical knowledge than was possessed by his contemporaries. The Mochlic was an abridgment of former treatises; in Woumds of the Head he formulated the rirtum concerning the possible danger of trifling womeds and the possible recorery from those most serious, so often ascriberl to sir Astley Cooper. Other monographs, also, he wrote, on Diseases of the Eye, on Fistula, and on Hamorrhoints. He described only a small number of operations, howerer. and all the Hippocratic writings on surgery would make but a very incomplete treatise as compared with those that belong to the next historical epoch; all of which we have to ascribe-in the main-to prejudice against disscetion and innorance of anatomy.

From the earliest times physicians and writers occupiod themselves largely with obstetrics, as was most natural. The Hippocratic collection inchdes monographs on Generation; the Nature of the Infant; the Seventh Month of Pregnancy; the Eighth Nonth of Pregnency; on Accouchement; on Superfutution; on Dentition; on Diseases of Women; on Extruction of the Dead Fotus. The treatice on superfoetation concerned itself mainly with obstetrics.

On epidemics Hippocrates writes extensively, showing that he had studied them carefinly. He was among the first to comnect meteorological phenomena with those of discase duming given seasons of the year expressing the hope that by the study of storms it would be possible to foresee the advent of the latter, and prepare for them. Seven books of the Hippocratic collection bear the title of Epidemics, although ouly two of them are exchusively devoted to this subject. In these books were contained a 
long list of elinical observations relating to various diseases. 'They constituter really a clinical study of disease.

'The collection of Hippocrates's Aphorisms fills seven of the books; 110 medical work of antiquity can compare with these. Physicians and philosophers of many centuries have protessed for them the same veneration as the Pythagoreans manifested for their golden verses. They were considered the crowning ghory of the collection. Even within a short time past the Ficulty of Paris required aspirants for the medical degree to insert a certain number of these in their theses, and only the political revolution of France served to cause a discontinuance of this custom. 'These aphorisms formed, sars Littré, "a succession of propositions in juxtaposition, but not united." It has always been and always will be disadrantageous for a work to be written in that style, since such aphorisms lose all their general significance; and that which seems isolated in itself becomes more so when introduced into modem science, with which it has but little practical relationship. But not so if the mind conceive of the ideas which prevailed when these aphorisms were written; in this light, when they seem most disjoined they are most related to a common doctrine by which they are united, and in this riew they no longer appear as detached sentences.

'The school of the Asclepiadie has been responsible for certain theories which have been more or less prominent during the cartier historical dars. One of these which previlited thronghout the Hippocratic works is that of Coction and Crisis. By the former term is meant thickcuing or elaboration of the humors in the body, which was supposed to be necessary for their elimination in some tangible form. Disease was regarded as an association of phenomena resulting from efforts made by the conservative principles of life to effect a coction, - i.e., a combination of the morbific matter in the economy, it being held that the latter could not be properly expelled until thus united and 
prepared so as to form excrementitions material. This elaboration was supposed to be brought about by the vital principles, which some called nature ( $P h y$ sis), some spirit (Psyche), some breath (Pneuma), and some heat ('Thermon). The gradual climax of morbid phenomena has, since the days of IIippocrates, been commonly known as Crisis; it was regarded as the amnomeement of the completion of the union by coction. The day on which it was accomplished was termed critical, as were also the signs which preceded or accompanied it, and for the crisis the physician anxionsly watched. Coction having been effected and crisis occurring, it only remained to evacuate the morbific material-which nature sometimes spontaneously accomplished by the critical sweat, mination, or stools, or sometimes the physician lad to come to her relief by the administration of dinretics, purgatives, ete. The term "critical period" was given to the number of days necessary for coction, which in its perfection was supposed to be four, the so-called quarternary, while the septenary was also held in high consideration. Combination of figures after the Pythagorean fashion produced many complicated periods, however, and so periods of 34,40 , and 60 days were common. This doctrine of crisis in disease left an impress upon the medical mind not yet fully eliminated. Celsus was the most illustrious of its adherents, but it can be recognized plainly in the teachings of Galen, Sydenham, Stahl, Van Swieten, and many others. In explanation, it must be said that there have always existed diseases of nearly constant periods, these being nearly all of the infections form, and that the whole "critical" doctrine is founded upon the recognition of this natural phenomenon.

The Hippocratic books are full, also, of the four elements,-earth, water, air, and fire; four elementary qualities,-namely, heat, cold, dryness, and moisture; and the four cardinal humors,-blood, bile, atrabile, and phlegm. 
Owing to the poverty of linowledge of physies and chemistry possessed by the ancients, and notwithstanding their arors and imperfections, the doctrine of Dogmatism, fommled mon the theory of roction and humors, was the most intelligible and complete among the medical doctrines of antiquity, responding better, as it did, to the demands of the seience of that day. 'That IIippocrates was a profound obsorver is shown in this: that he reminds both philosophers and physicians that the uature of man cammot be well known without the aid of medical observation, and that nothing should be affirmed concerning that nature mutil by onr senses we have become certain of it. In this maxim he took position opposed to the Pythagorean doctrine, and inchuded therein the germ of a new philosophy of which l'ato misconceived, and of which Aristotle had a rely faint alimpses.

Another prominent theory thromghont the IIippocratic books is that of Fluxions. moning thereby about what we womlel rall congestions, or conditions which we would say were ordinarily caused hy cold, though certain fluxions were supposed to be cansed by heat, because the tissues thereby berame ranefied, their pores enlarged, and their lumor attomated so that it flowed casily when compressed. The whole theory of fluxion was founded on the densent ignorance of tisines and the laws of plyssies, the body of man being sometimes likened to a sponge and sometimes to a sieve. 'The treatment recommended was almost as crazy as the theory. Certain other theories have complicated or disfinned the IIippocratic witings, and certain have been fonnded on the consideration of two rements-i.e., fire and earth-or on the consideration of one single element which was supposed to be air,-the breath, or pmenmr, and there was-lastly-the theory of any excedent, which is very vagrue; of all of these we may say that they are not of sufficient interest to demand expenditure of our time. 
The eclat which the second (i.e., the Great) Hippocrates gave to the school of Asclepiadie in the Island of Cos long survived, and many members of his family followed in his footsteps. Among his most prominent successors were Polybins, Diocles, and Praxagoras, also of Cos,-the lant of the Asclepiadie mentioned in history. Praxagoras was distinguished principally for his anatomical knowledge; like Aristotle, he supposed that the veins originated firom the heart, but did not confound these ressels with the arteries, as his predecessors had done, but supposed that they contained only air, or the vital spirit. It has becon claimed that he dissected the human body. He laid the foundation of splygmology, or study of the pulse, since Ilippocratic writers rarely alluded to arterial pulsations and described them as of only sceondary importance.

The predominating theory in the Island of Cos was that which made health dependent on the exact proportion and play of the elements of the body, and on perfect combination of the four cardinal humors. This was the prevailing doctrine,-i.e., the Ancient Meclical I)ogmatism, so named because it embraced the most profonnd dogmas in medicine, and was tanght exclusively until the foundation of the school at Alexandrit.

'Two men, however, more commonly ranked among philosophers than among physicians of anticpuity, dissected the statements of IIippoerates, and embodied them more or less in their own teachings, and thus exercised a great infuence on the progress of the human mind, particularly in the direction of medical study. The first of these was Plato, profoumd moralist, eloquent writer, and most rersatile thinker of his day or any other. He undertook the study of disease, not by observation (the empirical or experimental methor), but by pure intuition. He seemed to have never discovered that his meditations were taken in the wrong direction, and that the method did not conduce to the discovery of abstract truths. II galve beanty 
an abstract existence, and affirmed that all things beautiful are beantiful because of the presence of beatuty. This reminds one of that fimons response in the school of the Midclle Ages to a question: "Why does opium prodnce slere?" the answer being: "Because it possesses the sleepy principle." Plato introduced into natural science a doctrine of final caluses. He borrowed from Pythagoms the dogma of homogeneity of matter, and claimed that it had a triamgulir form.

Aristotle, equally great thinker as Plato, but whose mental activity was minifest in other chamels, was born i3.c. 38t, in stangria, in Macedonia. He was fascinated by the teachings of Plato, and attained such eminence as a student that King P'hilip of Marcelon made him preceptor to his son Alexander, suberpuently the Great, by whom he was later fumblied with sufficient funds to form the first linown muscum in natural history,-a collection of rare objects of crely sort. tram-mitted. miny of them, by the royal hands of his former student firom the remote deptlis of Asia. Ari-totle, by lomg odels the greatest naturalist of antiquity, laid the first philosophic basis for empiricism. The admitted four elements-fire, air, earth, and water-and believed them susceptible of mutual transmutation. He studied the nature of the soul and that of the animal body; regarded heat and moisture as two conditions indispensable to life; dereriber the brain with some arenacy, but withont the last idea of its truc function; said that the nerves proceeded fiom the heart; termed the aorta a nerrous vein; and male rarious other mistakes which to us seem inexcusable. Nevertheless. he was rich in many merits, and no one of his age studied or searched more things than he, nor introduced so many new facts. Although he never disected hmmin hodies, he nerertheless corrected errors in anatomy held to by the Iipporratic school. Ile dissected a large number of anmals of erery species, and noted the varicties of size and shape of hearts of various animals and 
birds. In other words, he created a comparative anatomy and physiology, and the plan that he traced was so complete that two thousand years later the great French naturalist Cuvier followed it quite closely. If he be charuged with having propagated a taste for scholastic subtleties, he also furnished an example of patient and attentive observation of Nature. IIis history of animals is a storehouse of knowledge, and his diseiples cultivated with zeal anatomy, physiology, and natural history. His successor, Theophrastus, was the most eminent botanist of antiquity.

It will thus be seen that Plato and Aristotle were the eminent propagators of two antagonistic opinions. One supposed knowledge to be derired by montal intuition, and the other that all ideas are due to sensation. Both comnt among moderns some partisans of the greatest acnmen: Descartes, Leibnitz, and Kant being followers of Plato, and Bacon, Locke, Hume, and Condillac, of Aristotle.

The excuse for stating these things, which apprarently do not so closely concern the history of medicine, must be that of the learned interpreter of the doctrine of Cuvier, that "The first question in science is always a question of method."

Hippocrates formed a transition between a period of mythology and that of listory. His doctrine was received by contemporaries and by posterity with a vencration alin to worship. No other man ever obtained homage so elevated, constant, and miversal. A little later ignorance reigned in the sehool that he made celelmated. Methods and theorics were propagated there under the shadow of his name which he would have disowned.

Medical science now changes its habitation as well as its aspect, and from the record of Hippocrates and his work we turn to the fourth period of the Age of Fommdation,-namely, the Anutomic, which extends from the foundation of the Alexandrian library, 320 s.c., up to the death of Galen, about the year A.D. 200. 


\section{C'IAP'TER II.}

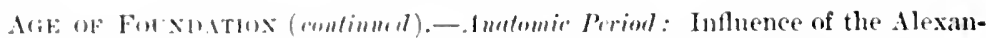
drian libary, Herophilus and limsistalus. Celsus, A.n. †50(?).

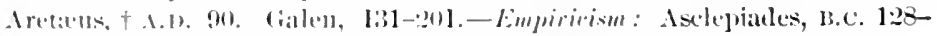

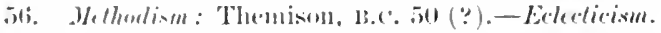

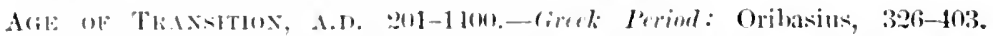

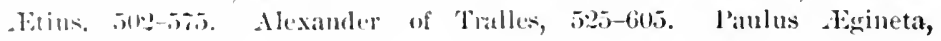
$(625-69411$.

Foenth, on Axatomic, Peniod. - As already seen, Alexumler the Great and his successors collected the intellectual and natumal riches of the miverse, as they know them. and placed them at the disposal of studious men to benefit lumanity; their complete value has not yet been exhansted, and nevel can be. 'This mulertaking was carried ont nuder conditions that made it one of extreme diffinuly. Manuscripts were then rare and most costly; but few copies of a given work were in existence, often only one, and these were lurd almost priceless. Under these ciremmatances the establishment of a publie library aud of a muscum was an act of philanthropy and liberality simply beyond culogy, and did more to immortalize the fommler of the collection than all his victories and oilher achicrements.

'Ihis appear's to have also occurred to two of Alexauder's licutenants-one Eumenes, Governor of l'ereamos, and the other, Ptolemy. Gorernor of Egrpt. After the death of the conqueror his generals shook of all dependence upon the ecutral government. and endearored to centralize their own anthority. But these two were the only ones among so many loaders who dicl not devote all their attention to armies and invasion, but interested themselves in commerce. and arts. So active were they in the enterprise that linmenes had gathered two hundred thousand volumes for the library at Preramos, and Ptolemy six to seren hundred thomsind for that of Alexandria. The latter was 
divided into two parts, the greater and the lesser, the latter of which was kept in the temple of Serapis, henee known as the Sercpium. These notable efforts to fomel anolmous collections first excited praiscworthy rivally among contemporaries and rulers, which, however, degenerated into eontemptible jealonsy, so that some of the rulers of Alexandria even went so far as to interdiet the exportation of papyrus, in order to prevent the making of copies for the library of Pergamos. But the effect was mexpected, since it led to the invention of the paper of Pereamos, otherwin called parchment, which completely displaced the pith from which papyri were made. Be this as it was, the collection at Alexandria had a much more marked influence on the medical study of the future than that of Pergamos. and calls for our particular notice. About it sprang up first a collection of learned men, and then the inevitable result-a school of learning. It was Ptolemy Sotcr who alled around him the most renowned men of his day. IIo provided them with homes adjoining the library, endowed them with salaries, and charged them with the elassification and collation of manuscripts, or with the giving of instruction by lectures and discussions. Ptolemy himself sometimes took part in these feasts of reason, which became still more frequent and formal under his son Ptolem! Philadelphus. These were ealled the Feasts of the Muses and of Apollo,-i.e., 7udi muserum, -and, consequently: the place where they were held came to be termed the "museum." Often the subjects for discussion were announced in advance, and those who gained the most applause received rewards in accordance with the merits of their work. Among those who enjored these advantages under the reign of these two Ptolemies are prominently named two physicians, ILerophilus and Erasistratus, the latter said to be the grandson of Aristotle. It was under this Philadelphus that the Hebrew wise men tranlated into Grcek the IIoly Scriptures, which translation 
hats since been called the Septnangint-so called because it is supposed to have been translated by the members of the sinhertrim, which was composed of about seventy men, or becanse, according to another legend, it was translated by serenty-two men in seventy-two hours. These suvants of ancient Eryt, thus supported by the dynasty of the Lagides, gare the first place to the seicnce of medicine. As regards this study, the school of Alexandria eclipsed almost from its origin the ancient schools of Cos and Pergamos, and during its existence was the leading institution of its lind in the world. At the time of Galen it was sufficient to have studied there, and even to have resided a short time in Alexandria, to obtain the reputation of being a plysician. Nearly all the scholars of these five centuries had received instruction in this school. The principal reason for its eminence in medical instruction was the practice of dissection of human bodies, which, muder the Ptolemies, was allowed and recommended, and by which the science of medicine received an extroordinary impulse. Although the prejulice of Egrptians was very strong against those who tonched a deal body, the Ptolemies themsclves are said to hare participated in this kind of anatomical stndy, thus destroying by their example the odium previonsly attached to dissection. Strange to say, however, the practice of dissection fell into disuse toward the end of this Anatomic leriod, and scholars preferred to indulge in subtle metaphysical discuscions rather than study human tissnes. But the principal reason for gring up this prace tice was the Roman domination of Egypt, the Romans, inconsistently, being perfectly willing to see any amount of bloodshed in the arena, and all sorts of inhumanities practiced upon living luman beings, but holding that contact with a corpse was profination; so that not a single anatomist of reputation had his origin in ancient Rome. "If on any oceasion," says Renouard, "a foreign phrsician attached to the ling or general desired to a rail himself of 
the occasions that were afforded to cxamine the structures of the internal parts of the human body, he was obliged to conceal and carry off during the night some body abandoned to the birds of prey." "To complete the melincholy termination of the Anatomic Period, the labors of the writers of those days were all lost by the burning of the great library by Julins Caesar, which was the begimning of the chain of disasters with which Eggyt was accursed under Roman dominion. Although Mark Antony, indnced thereto by the endearments and solicitations of Cleopatra, transported the library of Pergamos to Alexandria, even this was mavailing to restore the position of the school, since the atrocions and imbecile Caracallat took from the pensioners of the museum their privileges of common residence and every other adrantage, and suppressed all public exhibitions and discussions. I can mention but few of the names most eminent during this Anatomic Period, and but a short account of the life and work of each.

The first deserving of mention was IIerophilus, who was born in Chalcedon about the end of the fourth century before Christ, and supposed to be the first to undertalie systematic dissection of the human body. The so-called Torcular Herophili, or common meeting-place of the sinuses at the occiput, named after him, gives eridence of his influence upon the study of anatomy. He wrote on all departments of medical science, concerning the eyes, the pulse, midwifery, etc., as well as numerous commentaries upon the Hippocratic writings, - describing the membranes of the brain and its vessels, the choroid plexus, the ventricles of the brain, the tunics of the eye, the intestinal canal, and certain portions of the vascular system. IIe alluded to the thoracic duct without knowing its purpose, and gave a more accurate description of the genitalia than any previous writer. Strange to say, but little is known of his later life, and of his death absolutely nothing. 
Erasistratus was the son of C'lcombrotus, a student of Metrodorns, and lived for some time at the court of Seleu(ous Ninator, whose som, Antionhus, he liealed of a secret ailment, which happened to be a desperate love-affair with his step-mother, stratonice. He wrote extensively on ferers. hregiene, paralyses, therapentics. and many other sulpiects: reganded mont discases as due to orerindulgence in food. which is not digested, and consequently putrefies. l'lethora was for him the prevailing disease, against which he employed not only renesection, but fasting, and bandaring of the extromities. Ho was a diligent student of anatomy, and carefinly described the brain in many of its erosser features, regarding it as the seat of the soul and the centre of the nerves. In also described more exactly than his prelecessors the valves of the heart. which organ he renariled as the origin of reins and arteries. He discor(red the lymph-ressels, and maintained, against l'lato and others, that the epiglottis prevents the entrance of fluids into the lumge, but he supposed digestion to be produced by mechanical trituration in the stomach, and preferred grimnastics, exerrise, diet, and baths to dings or other therapentic monsures. He died abont 280 b.c.

Comelins Celsus, the most colelmated author for a number of conturies, was horn in Rome about the time of Clurist. Brilliant as he was, he exerted a wide-spread influcuce for enturies. The exact date of his death is mulinown. He was a contemporary of the greatest philosophers. poets, and suents of Rome during its most brilliant period. Ho studied rhetorice, philosophy, the art of war, eronomic's, and medicine-lie was, in fact, a walking encycloperlia of the knowledge of his day; hut it is in medicine that he shows to best adrantage, and in his capacity as a phrsician he was and is hest known. The direction in which C'elsus appears to least advantage is in failure of power of direct observation, and in rielding unquestioning obedience to the riews and dicta of Hippocrates, for whom 
he possessed the greatest reverence, not being able to brook any serions contradiction or opposition to his oppinions. In this reverence for Ifippocratic anthority he was followed hy many less prominent sucesssors, the consequence being a failure to train men as observers, the coldatvor being to make them simply storehouses of information derived from Hippocratic writings. As a result, Celsus wrote hut little, or else his writings are lost. Ile contented himself mostly

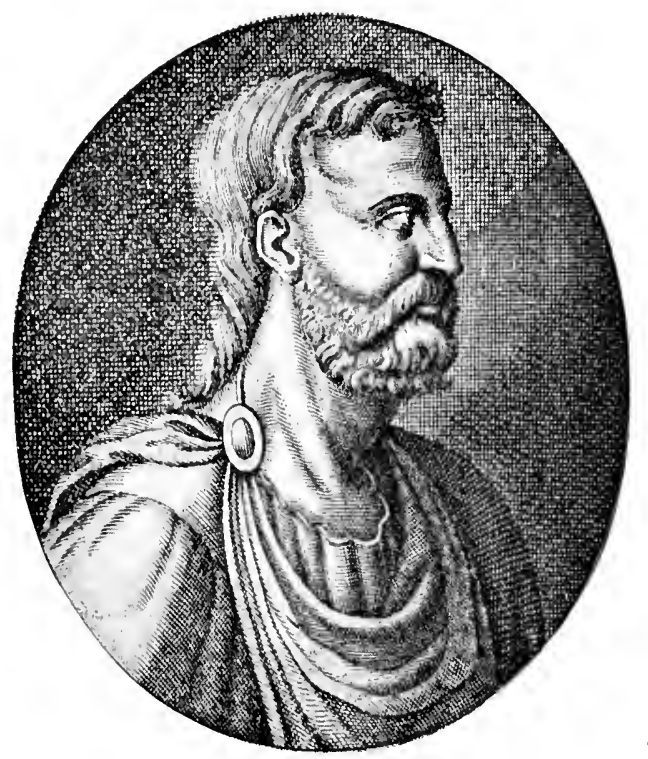

Fig. 4.-Aulus Colnelies Cetsus.

with a mere commentary upon the writings which he so highly revered. But little of his writings remain, and these pertain mostly to the therapentics of curable disease, dietetic, pharmacentical, and surgical. Although he exereised great anthority during his period, he was later totally supplanted by Galen, and his views are seldom mentioned in the writings of those subsequent to this great physician. His death must have talien place about the middle of the first century after Christ. 
Aretiens, who dicel about A.b. (U, was one of the most brilliant lights of antiquity previous to the Christian era, but, in spite of all this, of his life very little is known. He came from ('appalocia about the end of the reign of Nero, and lived in . lexandria. That he lived in Alexandria is apparent from his numerous references to its location, to the habits and thempentics of the Egrptians, and to the grography of the comntry. Furthermore, references to its diseases abound in his writings, so that it is made to appear that he had had the best advantages there, although he mut have traveled extensively. But a small portion of his writings remain, and these consist, for the most part, of compendiums of pathologr and therapentics. He described discase, not in anatomical oreler, from head to foot, but under the classification of acute and chronic. With the exception of Ilippocrates, he has shown himself the most fiee from rague, arbitrary speculation, and from the dogmatism of the schools of any witer of antiquity. He, more than any other up to his time, endearored to found patholong upon a somd anatomical basis. For every pieture of clisease he endearored to provide a suitable anatomiral accompaniment. This appears particularly, for instance, in his description of intestinal ulcers due to dysentery, or the paralyses following brain affections, or his drecription of pharyngeal diphtherias, of which he gave a wood account meler the name of Syriac or Egyptian ulcers. lubmonary tubereulosis, tetamus. and anal fistula are amply montioned in his writings. IIis therapenties were simple and rational; he laid weat stress mpon dietetic treatment. Ilis surgical writings appear to luave all been lost, but there is every reason to think that he brought to bear upon exterual medicine the same good sense which he applied to internal affertions.

Of all the students of IIippocratic dogmatism, the most skillful and learned was Clandius Galen (131-201), a native of lergamos, a place alleady celebrated for its temple 
dedicated to Esculapius, for its school of medicine, and for a library which had been remored to Alexandria. He was placed by his father moler the most distinguished teachers in all of the sciences, and even as a young man showed extraordinary progress, and became early a disputant with the most erudite in grammar, history, mathematics, and philosophy. He has related how in two different dreams

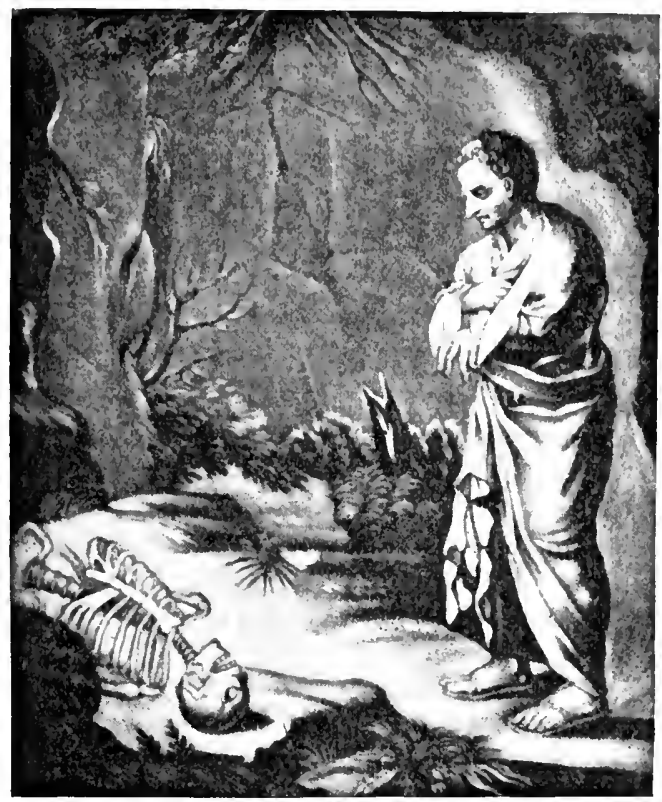

Fig. 5.-The Conversiox of Galen.

(From an old engraving published by R. Sayer \& J. Benuett, London, 1775.)

he was urged by Apollo to study medicine. He traveled widely for instruction, and remained some time in Alexandria. On his retum to his own comtry he was charged by its ruler to dress the wounded in the great circus, which furnished him opportmity for displaying all his anatomical knowledge and surgical skill. Not remaining long at home, he went to Rome, where his renown had preceded him, and where, by his brilliant elocution, his accurate 
logie. and his profonnd endition, as well as his versatility and practinal skill, he at once took the highest place. But here his rapid success, his ranity, his disdain for his colleagrues, and his useless boilsting, as well as his natural jealonsy, ganined him the enmity of nearly all his contempolaries, and his stay at Rome was thereby made very disingreable. In his work on Prenotions he accuses his colleagues of base jealousy and stupid ignorance, lavishes upon them such epithets as "thieres" and "poisoners," and closes by salving that after having mmasked them he would leave them to their eril designs by abandoning the great city to seek a home in a smaller place, where the surroundings would be to him more congenial. This threat he carried ont, but soon retmined to Rome upon the invitation of the Emprers Marcus Aurelius and Lucius Verus, whose confidence, as well as that of their successors, he enjoyed. He is supposed to have lived to the age of serenty-one, and to have died about 201 A.D. Galen strongly denied being attached to any of the sects of his day, and regarded as slaves those who took the title of Ilippocratists, Praxagoreans, Herophilists, and so on. Nevertheless, his predilection in firor of the Hippocratic writings is well marked. for he explains, comments upon, and expands them at length, refintes the objections of their adversaries, and gives them the highest place. He says: "No one before me has giren the true method of treating discalse; Hippocrates, I confess, has heretofore shown the path, but as he was the first to enter it he was not able to go as far as he wished. . . . He has not makde all the necessary distinctions, and is often obscure, as is numally the case with ancients when they attempt to be concise. Ile says rery little of complicated diseases; in a word. he has only sletelied what another was to complete; he hals opened the path, but has left it for a successor to enlarge and make it plain." This implies how he regarded himself as the successor of Hippocrates, and how little 
weight he attached to the labors of others. He: held that there were three sorts of principles in man: spirits, humors, and solids. Thronghout his metaphysical speculations Galen reproduces and amplifies the Ilippocratic dogmatism. Between perfect health and disease there were, he thonght, eight kinds of temperaments or inperfect mixtures compatible with the exercise of the functions of life. With Plato and Aristotle, he thought the human soul to be (omposed of three faculties or parts: the vegetative, residing in the liver; the irascible, having its seat in the heart; and the rational, which resides in the brain. He divided diseases of the solids of the body into what he called distempers; he distinguished between the continued and intermittent ferers, regarding the quotidian as being cauned by phlegm, the tertian as che to yellow bile, and the quartan as due to atrabile. In the doctrine of coction, crises, and critical days he agreed with Hippocrates; with lim he also agreed in the positive statement that discases are cured by their contraries. From all this it will be seen that Galen must be regarded as one of the earliest of Hippocratic dogmatists. IIe was a most extensive writer, and it is said that the total number of his works exeeeded one hundred. His contributions to anatomy were not insignificant. For myology he did a great deal. He wrote a monograph on the skeleton in which he recomnended that bones be seen and handled, not merely studied from books, and that the student should go to Alexandria, where teachers would place before him the real human slicleton. It has been inferred that there was not, in his time, in Rome a single slieleton. He wrote fiftecn books on anatomy, of which six are lacking; also an extensive treatise on the lesions of the human body, distributed among seventeen books which have come down to us. He is supposed to have introduced the term "sympliysis," and he described nearly every bone in the human body. By" him the muscles were no longer considered as inert masses 
and tissue-layers servingr to cover the bones, but he classified them according to their distinct functions, and studied sepalately their form and uses. The loeation of the ressels and nerves between them was also noted, and it was proved that muscles were indispeusable to the accomplishment of voluntary motions. Galen was, perhaps, the first rivisector of all, since he exposed muscles of living animals, and showed how alternate tension and relaxation of distinct eroups set the bones in motion, after the mamer of levers; he named a great 11 umber of them, but, curiously, took no note of others. His chassification according to their uses is followed down to the present day-i.e., flexors, exteusors, etc.

'The Ilippocratic anthors confoumded the arteries with the reins. Praxagoras first distinguished two kinds of ressels which he supposed to contain air, whence the name artery. Aristotle and Erasistratus maintained this view, which previled until the time of Gialen, who devoted a book to the refutation of it, basing his argument upon the observation that always when an artery is womnded blood gushes out. How near he came to being the discoverer of the circulation may thus be seen. A little less reverence for authority and a little more capacity for observation would have placed him in possession of the knowledge, lack of which for so many centuries retarded the whole profession. Ile thought the veins originated from the liver -in this respect being behind Aristotle-but considered the heart as the common sonrce of the arteries and veins. Even the portal system of reins contused him, and he (rroneously deseribed a superior and inferior aorta, but atoned for this by deseribing the nmbilical reins and arteries. Aristotle also had supposed all the nerres orioinated from. the heart, but Galen stated that they are derived from the lrain and spinal marrow, and pointed out two kinds of nores: those of sensation, which he thonght proceeded from the brain, and those of motion, which he 
considered to originate in the spinal marow. Thus, he described distinct nerves of sensation and motion, but sallly confused their anatomy. He seems also to have had some notion of the great sympathetic, although it was by no means accurate. He suggested the division of the principal nerves, in order to prove the fact that nerrous encrey is transmitted from the encephalon to other parts of the body. He speaks of glands, and thought they discharged their secretions through veins into the varions calvities, but regarded them rather as receptacles of excrementitions matter than as agents for secretion of valuable fluids. He even regarded the mammie as glandular bodies in this sense, althongh he knew, of course, the value of their secretion. To Galen we owe the division of the body into cranial, thoracic, and alodominal carities, whose proper viscera and envelopes he described. He spoke of the heart as having the appearance of a muscle, but differing from it. He regarded it as the somrce of natural heat, and the seat of anger and of violent passions. IIe appreciated that inspiration is carried on by enlargement of the thoracic cavity. He thought that atmospheric air entered the carity of the cranium through the cribriform plate of the ethmoid and passed out by the same route, carring with it excrementitious humors from the brain, which were discharged into the nasal fosse. But some portion of air thus entering remained, according to his views, and combined with the vital spirits in the anterior ventricles of the brain, from which combination originated the animal spirits and inmediate agents of the rational soul. These acquired their last attenuation in the fourth ventricle, whence they would pass out drop by drop through a round, narrow tube.

From this brief résumé of the anatomy and physiology of Galen it will be seen that by the end of the second century of the Christian era immense progress had been made since the foundation of the Alexandrian school, and that it was due to the impetus in the study of anatomy given by 
Herophilus and Fiasistratus, who not only made numerous dissertions. but resorted to frerpuent vivisections. It is eren said that Iferophilus did not hesitate to employ his knite on live criminals who were suljected to him for experiment; but this has been a popular tradition about almost every anatomist of antiquity, and there is no evidence in contimation of the mukind rumor, although that such experiments might be legally and justly performed hats ocerurred to the minds of many. But zeal for dissection rapilly cooled oft. and Gallen barely mentions five or six men who deroted themselves to it in the space of nearly four hundred years down to his time. Ie speaks of Rufus of Ephesus, who lived under Trajan; of Marinus, who wrote in the beginning of the second century A.D.; and of Quintus, who instructed his own preceptor. None of them left a reputation, howerer, approaching that of Herophilus and Emsintmatus. with whom Galen alone could compare ly the number of his experiments and his discoveries. Gialen strove as hard as one of his position might, by example and precept. to awaken in his contemporaries a derire for anatomical knowledge. but could not overcome their indifference. After him the practice of dissection appears to have been lost, either from the redonbled prejudires of the superstitions, who opposed it, or as the result of the apathetic ignorance or the ignorant apathy of the phicicians.

It has been shown that, dnring the Hippocratic era and subspantly, the phrsicians even of primitive times followed more or less ly instinct the empirical method. Acron of Agrigentum was a contemporary of Pythagoras, and atfirmed that experience is the only trine foundation of the healing art. Hippocrates, however. showed himself more anxions to report fiathfinly clinical facts than to dispute theoretical views.

The smrprising progress in anatomy and physiology made during the first portion of the Anatomic Period and 
during the better days of the Alexandrian institute did not keep men from eonfounding sereral different points in the IIippocratic doctrinc, by which confidence in the same was naturally shaken. Thins many new speculations were hazarded which mullified anch other. In the midst of this confusion practitioners continned to serk in experienese a refuge from the incessant variations of dogmation and the sterile incertitude of the skeptics. 'Thus, empiriciom as a school of practice became placed upon a firmer and firmer foundation, and the empirics of that day secm to have lavid the true basis of our art. 'Tlueir doctrine took at first a rapid growth, and Galen spolie of it with great regard. The eireumstances nuder which it was proclaimed were most farorable for its propagation. Theories had fallen into confusion; practice, methods, and opinions were questionable. Ererything was conjecture, and that which rested on the evidence of lacts was by the empiries received with enthusiasm. Although founded on pure observation, it did not put an end to differences of opinion, and in the eyes of the ancients it lacked in solidity, because it did not attach itself to any philosophic theory then known. This doctrine was then best able to captivate physicians on account of its simplicity, contrasted with the general inability to satisfy specnlative minds; but for this rery reason it subsequently fell into disgrace, and the term "empirieism" became synonymous with ignorance. For centuries condemned and despised, it was revived from its long humiliation under the name of the Fxperimental Method, and achieved, after the labors of Bacon, Locke, and Condillac, almost universal dominion in the sciences.

This doctrine had been proclaimed for about a century during the period of which we now speals, but later led men into a fondness for secondary generalities or for the elevation and magnifying of trifles, which confused their minds and terminated its usefulness to science. Meanwhile, a man of great intelligence, renowned as an clo- 
cutionist, well rersel in the doctrine of philosophers and frammarians-namely. Asclepiades, of Bithynia-came to liome with the intention of teaching rhetoric. By his talent and fersonal aldress he soon hecame one of the most illustrions peroms in the Roman Republie; so early as 100 B.9. he enjoyed a high reputation as a rhetorician, and was later an intimate friend of Cicero; nevertheless, he ahandoncd lettris, undertook the practice of medicine, and solleht moreover to croate a new syotem, being unwilling to follow in the track of his predecessors. Imbued with the philosophy of Epiemrus, who was then in lighl repute, he deduced from it a theory which was in harmony with the philosophy of the day. He thought that the elements of the body existed from ctemity; that they were indivisible, impalpable, and perecpetible to the reason only. These elements he named afoms, which were supposed to be animated hy perpetual motion. and from which, by their frequent encomiters and fortuitous contention, all sensible phenomena were smplosed to result. He explained the properties of the body by saying that compounds were angregates of atoms, differing very much fiom atoms themselves. Siolid silver, he said, is white, but, reduced to powder, appears black; the horn of the goat, on the contrary, is blark, but if it be razod its particles are white. 'This, it will be scen, was the parent of our present atomic theory. Ile ridiended the theories of Hippocrates concerning coction. crises, etc.. and sarcastically called the llippocratic treatise on therapentics "a meditation on death."

Aschepiades hased his own therapentics on endeavors so to mulage the pores of the lumman body that discase comlit find enress. on so to constrict them that it could not enter"; comsoquently he rejected all violent remedies, such an romits, jureses ete. and his favorite remedies were hygienic,-for the most part hodily exercise.

A celobrated disciple of Asclepiades was Themison, of landicea (B.C. j()). who was led by the teachings of his 
master to lay the fomdation of the so-ralled Methodism as opposed to Dogmatism in the school of ('os. liy him and his followers a very arbitrary allangement of discases wats made, according to what they considered the constrictive, or contractive; the fluxionary,-congested or relaxed ; and the mixed forms. From this dirision of discases it alpealls that, according to the methodists, there were only trio kinds of therapentic indications to follow,-namely, to relax where there was constriction, to eonstrict where there was relaxation. 'They, howerer, admitted a thinel creditable result, which they called prophylactic; but the pure methodists, such as Coelius Aurchianus, admitted neither specific disease nor specific remedies, and erased from thein materia medica purgatives, diureties, emmenagognes, manseants, etc.

According to the methodist doctrine, the study of medicine was so abridged that one of its prominent exponents said that he felt able to teach the whole of medical science in six months. It made rappid progress, and consequently was most attractive to the numerous young neophytes who were anxions to finish their apprenticeship and hasten into practice. It is not one of the smallest of the services which Galen rendered to his time and to posterity that he demolished the sophistry of the methodists, demonstrated the insufficiency of their practice, and brought to bear upon them the wittiest satire, calling them the asses of Thessaly, alluding thereby to their lack of literature and medical instruction.

In summing up, then, the basis for the various systems of medicine during this period of antiquity, it is seen that the most ancient doctrine of all-Dogmatism-directs onr attention especially to the animal economy in health and disease; that it took accomnt of the mion of vital forces, of sympathies in the organism, and of nature's efforts to repel both internal and cxternal deleterious influences, 
which poricionial toudency manifests itself especially in erertain ande discases. 'This was the stroug side of dogmation. Its wark side comsinted in this: that it was loeld that the rallses of diseases inhere in the aceess of ecrtain qualitics and hommors along with organic forces,-such as drynos or moi-ture in combination with bile or atrabile, and the treatment was directed against these supposed rances. It was on alecemut of this weakness that the onemires of dogmatism attarelied it. The empiries opposed the idea that inacessible and occult anuses of disease conlel become the basis for rational treatment. 'They aftimed that there was no rousistent relation of antagonism or similitule between the disease and the remedies which amod it.

The Methorlists somewhat improved on the doctrine of empiricism. bnt ran wild in its implorement and erected over their findamental theory such a superstructure of secondary and tertiary enemeralities as to cause the fundamental part to be entirely obseured from sight.

There were not lacking. in those dars of old, certain elucated phrsicians who more or less raguely comprehended that the entire truth of modicine did not inhere in any one of these systems, but that there was good and evil in each. These men, not heing able to establish wencral moles triod to decide practical questions according to their faney or their reason. 'They assuned the name of Erloctics or Episymlletirs, meaning thereby that ther adopted no exchusio sytom, but selected from eacli that which seemed to thrm best. They did not constitute a secet, because they had no precise dogmas nor theories, but they should not be confomded with the Pyrhonians, who hold to doubt as a fundament doctrine, the true eclectic doubting only that which he could not understand. True eclecticism in melicine. howrver, is rather the absence of fised principles. or. as Renonard says, it is "indiridnalism crected into a dogma. which escapes refutation because it 
is deficient in principle." Many became edecties to aroid discussing principles, and made of it a shelter. In one sense, then, an eclectic is one destitute of profound convictions, who sides with no particular party, is committed to $n$ person or doctrine, and who is often so indifferent that he camnot judge with impratiality; consepuently, to be truly eclectic is different from being an adherent of a school of ectecticism.

During the historie period just reviewed, anatomy and physiology made most progress, next internal and extemal nosography, and next to these medical and sureical therapentics, and although Coelins Aurclianus and Areteus have left to us by far the hest bookis issned up to their times, nevertheless not one of the writers of this period has achieved the distinction in which llippocrates is held, since he, perhaps more than any other, combined intelligence, sincerity, disinterestedness, love of his art, and humanity.

Under the classification of Renonard, already alluded to, the so-alled Age of Trunsition inchdes centuries commencing with the death of Galen, about A.D. 201, and ending with the revisal of letters in Europe, about the year 1400 . The first period of this transition ane is the so-called Greek Period, which ends with the buming of the Alexandrian library, A.D. 640.

At the time when this historic period commenced all the known world was under the dominance of a single man. The power of Septimus Severus had more extent than that of Alexander the Great, and bid fair to be of a much longer existence. The Roman dominion, cenented by seven hundred years of hold and persevering government, seemed almost immorable. While the savages upon its frontiers occasionally troubled its peace, none were strong enough to penetrate its centres or place it in real peril. The great civil wars had ceased, or changed their object. 
Both the people and the semate, thowe two eternal competitors. hand gotten orere the strugare for supreme power; momalchial govermmont Wis aceopted ats a matter of fact, and the citizens contended only tor rhoice of a master.

rimilar ahanges had talion platere in the domain of the mind: philosophical discussions. Which were so essentially a part of the schools of the ancient Gireelis, had nearly lost thrie interent and were bring di-continued. Such disputes as took plares leclated less to principle than to interpuetation of the limernage of the teacher. In morals, Plato. Epicurros. and hono were followed mutil the prineiples of C'hristianity gradually supplanted their tearhing : in physies and motaphysies the antloority of Iristotle, and in medicine that of (ialen, were simply minlisputed.

(onditions being such as these, there was naturally but one sect in medicine, and one method of study and practice. Medical science retrograted rather than progressed, sad to say, and was undisturbed by any remarkable revolution. The scepter of medicine passed firom the hands of one nation to those of anotlere, and the language of Hippocrates and Cialen was later replaced, as will duly be seen, by that of Aricemer and Albueasis. But this Greek P'oriod, wheh is one of tramition. ofters little for our consideration more than the lives and writing of form of its most eminent physicians, who by their study in the school of Alexandia. and by their wrings and fouchinge, left reputations which were sistained mutil the invasion of the Alabs. Of these it may he said that, while they did little or nothing original, and simply commented upon the writings of Ilippromes and (ialen, they kept buming the toreh of medical leaming wheh else had becm almost extinguished by their indelent antemporaries. Of these varions commentatorsfor they were little more than that - the first of any importance after (ialen was Oribasins, who was born in Pergamos (326-403); he early attached himself to the fortmes of Julian the Apostate. and followed him into Gaul when 
he was made its governor. Julian appreciated the good qualities of Oribasins, made him an intimate friend, and after he himself became emperor appointed his friend as quiestor at Constantinople. After the emperor's mutimely death, Oribasius remained faithful to his memory, but his jealous colleagnes so falsely and so surcessfully misrepresented his fidelity that he was disgraced, spoiled of his office and property, and bantished among a barbarous people. In this new field, howerer, he displayed such comage, effected such extraordinary cures, discoursed so eloquently, and so attached to himself the savage men around him, that he was by them regarded as a god. The fame of this lomage in time reached the cars of the Lmperors Valens and Valentinianus, who recalled him, reimbursed him for his losses, and permitted him to enjoy his high reputation and fortune to the end of his days. Ile was held to be the wisest man of his time, most skillful in medicine, and the most charming in conversation. IJe dedieated a collection of serenty books to Julian, his first patron, and edited, at a later period, an abridgment of this work for the benefit of his son. Ifis principal merit consisted in reproducing the ideas of others with such clearness, order, and precision that the summaries that he gires of them are often preferable to the originals. What he has said of pregnant women, nursing, and the earliest edncation of the child has been copicd literally by writers for twelve centuries since his time. It must he said of him, however, that his prepossession in faror of Galen was so great that he adopted servilely his ideas and even his words to such an extent that he has been surnamed "the ape of Galen."

Etius was born in Mesopotamia in the year 502 and died in 575. He studied at Alexandria, and afterward went to Constantinople, where he became a chamberlain at court. Etius was the first medical man of any note who professed Christianity, as is shown by such passages as this one: he 
said that in the composition of certain medicaments the following words should be repeated in a low roice: "May" the God of Almaham, the God of lsanc, and the God of Jacob deign to bestow upon this medicament such and such virtnes." In another place lie recommends that to extract a bonc from the throat the following words be pronomeed: "Joun-ass Christ calsed lazarus to come forth from the sepmlchre, as Jomali came out of the whale's belly-come out of the throat or aro down." But he exhibits the same credulity in not doubting the miraculous virtues attributed by the quaclis of his day to most remedies.

Like Oribasins, he collected everything that he found remarkable in the writings of his predecessors, and has preserved certain fragments of antiquity which would otherwise have been lost. Ilis work formed a complete mamul of medicine and surgery, except that it lacked anatomical descriptions and reforences to dislocations and fractures.

Alexander of 'Tralles (525-605), a eity of Lydia, where Greek was spolien, was a son of the physician Stephen, and the most celebrated of tive sons, who were all distinguished for their learning. Io traveled extensively, and tixed his residence in Rome, where he berame celebrated. He lived to an adranced age, and, being no longer able to practice, composed a treatise of twelre books, exchusively devoted to affections that did not require the aid of surgery. He professed the graatest reneration for Galen, but did not blindly adopt his opinions. II described the first reported case of excessive hunger and pain due to intestinal worms; he adrised renesection in the foot rather than in the arm; but with all his somnd judgment and montal enlightenment he had firith in ammlets and talismans, and widely recommended thrm. It may be said for him, such was the universal prejulice of his age, the whole world being plunged in superstition, that it was necessary for erery one to pay some tribute to the prevailing belief; and we may add that it is necessary to make this excuse for some who prac- 
tice much nearer to ourselves than did those ancient physicians.

Paul, or Paulus, sumamed Aigineta (beeause he was born in the Island of Agina), was among the last of the Greek physicians who have special interest for us. It is supposed that lie died about A.D. 690. He traveled extrusively, and his skill in surgery and obstetrics rendered him celebrated even among the Arabs, whose midwives sent for him in consultation from great distances. Ho composed a compendium of nedicine, divided into seren books, and not only did not hesitate to borrow from his predecessors, but quoted from them most extensively; a number of his chapters were taken almost verbatim from Oribasius; however, he made no secret of it, but rather boasted that he land judiciously sought to appropriate the best of the writings of those he most revered. Ile showed originality, however, in the treatment of hydrocephalus, in advising paracentesis of the thorax and abdomen, in the extraction of calculi from the bladder, in the treatment of ancurism, the excision of hypertrophich mammae in men, etc. He was the first to describe varicose aneurism, and the first to perform the operation of bronchotomy after the method borrowed from Antyllus, of which he has transmitted a very detailed account. Of this Antyllus, by the way, it may be added, en passant, that he was one of the most distinguisled and original surgeons of antiquity. He flomrished during the third century after Christ; was the first to describe the extraction of small cataracts; and is, perlaps, best known to the surgical world to-day by his exceedingly bold plan of opening aneurisms, so suecessfully imitated a generation or so ago by James Syme.

It has already been seen that before and during the early centuries of the Christian era the secrets and learning of the physicians tended to pass gradually into the hands of the priests. It was so in the temples of ancient Grecee, it was so in Alexandria, it became so in Rome, it has been 
so even in modern times, althongh only for brief periods of time. Ihis has come abont in some measure from the coppdity of the clerical orders, partly becallse it required a certain ammont of intelligence and linowledge to become a prient, and partly berallse, owing to ignomance, credulity, and smerstition, discases have at all times been reganded by the ignorant as eridence of divine wrath and chastisement, or of diabolical or ocentt inthenees, rather than the effecet of matural cances. Hence men have turned ever toward prayers, exorcism, and expiation, especially when exhorted thereto by the priests. 'This has been the sacerdotal anpert of the practice of medicine in all times, and when the priests hare monped therapentic functions they have done ham rather than good. So long as theology and science worli hand in hand, cach redounds to the credit of the other, lut always in the history of man when theologg has appropriated that which did not belong to it it lats bronglit ridicule mon itsolf and has delayed the progress of knowledge. 'There have been frequent rebellions against religions anthority in ancient as in modern times. For instance, at the commencement of the fifth fentury before ('hrist the lythagoreans were dispersed, and the doctrines of Cos and Cuidus-i.e.e the Ilippocratic teaching-were prommlgated; and, again, in the course of erents, when the descendants of Esculapins became servile attendants at the temple and adjunets to the priesthood or " part of it. At first. in Alexandria. the physicians were supreme; their disciples. howerer, had the same blind reverence for anthority that too many workers in the field of theology have evinced. and men once more practiced medicine on the traditions of the past, and in so doing allied themselves more and more to the temples.

In Rome. at first, the oldest and best instructed of the rehatives treated the diseases of his family as he understood them: simply shared this duty with its other members. Cato. the censor, was much engrossed with this domestic 
medicine; he wrote a book in which he reconmender cabbage as a sovereign remedy in many discases. If venerated the number 3 , as did the Pythagoleans; did not disdain to transmit to posterity certain medical words which it was believed should be repeated to assist in the reduction of dislocations and fractmes. 'Jlis old (emson' seemed to lave a profoumal hatred for medical mon, and most absurd ideas of their works and claims, although doubtless many Greek physicians who ame to liome merited the inrectives which he lamehed against them. 'Then came Asclepiades, of Bithynia, as already mentioned. whose talents were fir superior to those of his lioman contemporaries, and who did not need to call to his aid charlatanism and deceit. 'This medical hero morortunately hat many worthless and dishonest imitators, who appealed to superstition and ignonance in every dishonest way, and who desired to be judged by the luxury and elegance they dinplayed. Hence for a long time in Rome medicine was practiced withont license. The Emperor Anthony the Pions was the first to oceupy himself with regulating the practice of medicine. He granted certain immunities, but did ask for proof of qualifications. A certain physician to Nero, Adromachus, was honored by the emperor with the title of Archiater,-i.e., royal healer,-but Galen, who was physician to Marcus Aurelins, never bore it. From the time of Constantine the Great, however, the title is frequently met with in the edicts of the emperors. In finet. there were two sorts of these, - one mamed the Palatine, who belonged to the houschold of the reigning monarch and who held high rank among the nobility; and the other called the Popular Archiaters, who were public-health officers. No one could practice medicine in the jurisdiction of one of these without examination and authorization. Those who transgressed this regulation were punished with a fine of two thousand drachmas. The Popular Archiaters were pensioned by the city, enjoyed certain privileges, and 
had to attend the poor gratuitonsly. Practitioners who were not members of the College of Archiaters had no paly, no rights, nor comoluments. The Popular Archiaters were dected hy the citizens from many caudidates who hate proverl their alparcity betore the college of this medical

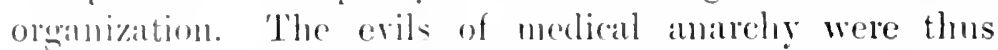
romedient; this happly condition existed until the empire was boken up by babanism.

It is chune this period-about 400 A.D. - that we first find a dass of atizons to whom was delegated the duty of preparing drugs ordered hy physicians. Their duties were in some respects similar to those of our apothecaries.although in attaimment and in social position they were far below the physians. They were termed pharmacompolints.

It is worth while to stop) a moment to inquire what were the medical charitable institutions of antiquity. Even in the days of anciont Athens there was a certain srommasimm. called the Crnosares, in which abandoned and illegitimate children wore brought up at public exbense mitil such time as they were able to serve their comutry. A little later sereral puivate institutions of this kind were entablished. liome in her carlier day never had such institutions. To be sure. she distributed provisions, or else remitted taxes, to parents who were mable to suppert their children. or eren permitted them to dentroy their newhorn childeen when mable to maintain them; but there were no homds of sympathy which induced the batricians to succor the plebeians in time of disease and dietress; slares were cared for as were cattle. It is one of the lahts we owe Christianity that, moler its influence, the first almolionses and retreats were established in Rome. It has been said that the Emperor Marcus Aurelius first imstituted anything like a dispensary service in the Sacred ('ity. We are tolel. also, of an illustrious woman, St. Panline, living in the midst of the greatest wealth and 
pomp, who retired fiom society and desoted lier life to eharity and self-denial. She went to Jemsalem, mited with other Christian women of the same mission. and formed, under the direction of St. Jerome, a sisterhood whose members divided their time between reading sarcred books and doing good works. Tliey offered an asylum for the faithful and a lospice for the benefit of the indigent sick, and even established a lome for convalescents ontside the city-rvalls. After the model thus set, heathen cmperors, Christian kings, and Moslem caliphs showed their zoal in this good direction by the erection of sumptuons edifices and other rich endowments for the relief of suffering human beings.

Reviewing now the Greck period, let it be remembered that in the time of Galen animals were dissected, and that he made anatomical demonstrations on monkeys; that sometimes the corpses of the enemy were rudely dissected upon the field of battle, but that finally the practice of dissection fell into disuse, and human anatomy was studied only from books, the carly Christians having evinced eren more horror of the dead body for the purposes of anatomical study than did their pagan predecessors, while the Fathers of primitive times lannclied their anathemas against the dissection of lumman remains. Ilere. again. als usual, the interference of the church worked only general harm. This abandonment of anatomy contributed doubtless to the decadence of medicine; by the rapid extension of Christianity the pagan schools were disorganized and broken up, the profane sciences (such as medicine) were discarded, and the teachers still remaining in the old selıools were rumed. Passion for religious controversy was engendered and took the place of study or original research, even to such an extent as to hasten the fall of the Empire of the East. In addition to these factors, rererence for authority of the past-that terribly oppressive weight which has kept down so much which would other- 
wise have risen early, and which has been the greatest enemy of human laning-permitted the explanation of natural phenomena to be sought only in the writings of revered ancients, and not in living beings. No one dared to adrocate changes in regard to received doctrines, and there could be no such thing as progress. Only two men in the lapse of four centuries showed any originality; these were Alexinder of 'lablles and Paul of Aggina, whose lives have already been briefly rehearsed. It is with some relief. however, that we can think that this period, so unforitful in scientific progress, was not so in social amelioration. By the organization of the institntions above alluded to charlatanism was checked, by the requirement of eapability and good character society was benefited, and the charitable institutes of this epoch perhaps gave the world its best models in teaching and an insight into the most valuable means of medical instruction. Of the old Greek Period, then. we may say that it accrues rather to the benefit of humanity than to that of science. 


\section{CHAP'TER III.}

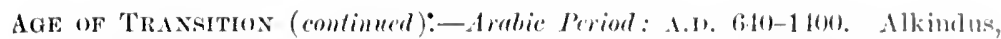

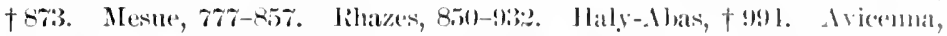

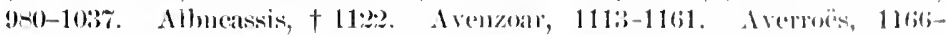
1198. Naimonides, 1135-1201. Sthool of Shelemmm: Constantinus Africanns, 1018-10R5. Roger of Sallemo, 1:210. lioland of l'arma, 1:20). The lour Masters, 1280 (?). Joln of Lrecida.

Trus Arabic Period, which began with the second destruction of the Alcxandrian Library - 640 A.D. - ends with the fourteenth century. At the commencement of this period the Roman Empire of the West scarcely existed: the magnificent territory which composed it had been overrum and subdued by barbarous tribes from the forests of the North, while from its ruins had risen several independent kingdoms, - that of the Franks in Gallia, of the Tisigoths in Spain, and of the Lombards in Italy. The last of the Western emperors of note was Justinian, whose army and generals-especially the genius and heroic devotion of Belisarius-threw some glory upon Italy, Sicily, Africa, and Spain. Mcantime the Empire of the East, smromded by enemies, and harassed from all directions, still sustained itself with vigor. The Turks had begun to show themselves on the banks of the Damube; those eternal enemies of Rome-the Persians-made incessant war; and a new and terrible enemy had sprung up in the deserts of Arabia. Then came one who was at the same time legislator, proplet, and conqueror, and mited under one faith and one leader tribes hitherto divided and warring against each other. Thus arose a powerful and enthusiastic nation, animated by thirst for conquest and ardor for proselytism. In less than a century after the first preaching of Mahomet, all of Arabia, India, Syria, and Egypt were in the hands of his followers. In the rear 640 Amron effected the conquest of Egypt, seized Alexandria, and the great library of five hundred thousand volumes was, by order of Omar (suc- 
cessor to Mahomet), delivered orer to the flames; and the historian Abulpharagins declares that these hooks serred for six montls to heat the public baths, four thonsand in number. Such were the first firuts of the establishment of lslam.* Ilappily, zaal of proselytism somewhat abated among the Mussulman princes, and religions ferror gave place to polieg; so that the later Arabian caliphs showed themselves, in general, the protectors of the ants and sciences. some, indeed, endeavored to collect the rébris of the scattered treasures that had been so fortumate as to escalpe the innorant fanaticism of their predecessors; and others, more tolerant even than the ('hristian princes of the time, received without distinction all mon of merit who took refinge in their State, gave them employment, and recompensed them for their services. On this account philosophers and persecuted *hereties" songht an asylum among infielels, and fomel there the protection which Christianity dicl not afford,-in return for which they gave their protectors the bencfits of Greek civilization.

Of all the Moslem rulers, the most distinguished for lore of leaming and general enlightenment was Harommal-Raschid, the Charlemange of the East, contemporary and emulator of the glory of the cmperor of the Franks, the hero of a hunderd Arabic poems, whose dominion extended from the borders of the ludus to the heart of the spanish peninsula. He embellished Bagedad, his capital, with schools and hospitals. His son Almamon fomded the Acalemy of Bagdad. which became the most celebrated of the age; likewise spared no pains to draw to his court the most illustrious men of all countries. He enjoined each of his ambassador's to purchase all the writings of the philosophers and physicians that conld be found, and these he required to be translated into Arabic; his interpreter, Ionain, a Christian, was employed at translating for forty-

* See a very vignrons lenial of this historical statement in The Nineteenth Century, October, 1504, patge 555. 
five rears, and recoived, for each book rendered into Arabic, literally its woight in gold.

The eclat which the Moorish caliphs shed upon Sinain from the tenth to the thirteenth century is well known. The cities of Cordova, 'Tolodo, Seville, aud Murcia possessed public libraries and academies, and students fom all parts of Furope flocked to them to be instructed in arts and sciences; the library of Cordova alone cmbraced more than two humbed and twenty-four thousand rolumes. 'Thus it will be seen that the dominion of mental and temporal affairs passed from the Greeks and Romans to the Salaceus.

Arabian medicine constitutes one of the most interesting chapters in the history of our art. An offspring from Greck schools, it was for nearly one hundred years the fostermother of that art, and, although it gave rise to no great discovery nor wouderful step in advance during all this period, it nevertheless licpt alive all the learning of the past, and clarified rather than made it turbid. In the sixth century the Nestorians (followers of Bishop' Nestor), having been driven ont of Syria, settled in Persia, Mesopotamia, and Arabia, and there founded schools and other institutions such as they had had at home,-schools in which, beside the ordinary philosophic studies, medicine received a share of attention. Thus it came about that by the serenth century Arabian physicians were everywhere known and in high repute. Naturally the basis for their studies embodied the writings of IIippocrates, Galen, Oribasius, and l'aul of Egina; and the tirst Arabian works consisted solely of translations from the Greek, first out of their Syriac rendering, and later from the originals. Indeed, so much eminence was finally achieved by Arabian physicians that more than four hundred are known by name as anthors.

The first author deserving of mention was Bachtischua. of Nestorian stock, celebrated in Jondisapmr, director of the medical school, and later physician to Caliph Al-Mansor, 
in Bagdad. Of his descendants sereral became well known in the same field.

Alkindus-this being the. Iatin arangement of his Arabic name-rame from a lersian family, who lived first in Basa and later at the court of the caliphs Al-Mamum and Al-Moutassem, in Bagrdad. He enjoyed a rery high reputation as physician, philosopher, astronomer, and mathematician, and died A.D. ST3.

Mesuc, the first of his name, sometimes known as Janus Damascenus, was director of the hospital in Bagdad and physician to Maromm-al-Raschid. He was boln in 7 \%, wrote extensively (since at least forty of his works have been catalogued), and died in 857 in Samara.

Serapion the elder, also sometimes known as Janus 1)amascenus, and wlose Arabic name was Serafim, was born in Damascus-the exact data is not known-and died some time prior to A.D. 930. He was author of two rolumes of aphorisms concerning the practice of medicine, which had at his time the greatest repute.

'The most celebrated of the early Arabian physicians was Rhazes, born in the Persian province of Khorassan A.D. 850 . According to the historians of his nation he was a unirersal grenius, equally famous in music, astronomy, mathematics, chemistry; and medicine; he was sumamed "The Experienced." At the age of fifty he was one of the most distinguished professors in the Academy of Bagdad, where students came from great distances to listen to him. Closen from among a hundred colleagues to direct the grand hospital of that city, he displayed indefatigable zeal and most scholarly learning, even to his old ane and in spite of loss of sight, which overtook him at the agre of eighty, when his reputation was at its height. 'liwo years after this misfortume-i.e., in 932-he died. Ilis generosity, which was proverbial, and his compassion for the poor left lim pemiless at the time of his death. Some two hundred and thirty-seven monograplis of his 
have been catalogued, though the greater number of his works are practically lost. 'Two treatises on medicine remain which afford excellent connsel in many respects; among other matters he advises:-

"Study carefully the antecedents of the man to whose care you propose to confide all you have most dear in this world,-that is, your life and the lives of your wife and children. If the man is dissipated, is given to frivolows pleasures, cultivates with too much zeal the arts foreign to his profession, still more if he be addicted to wine and debauchery, refrain from committing into such hands lives so precious."

His greatest publication was Liber Continens-extracts compiled from all authors for his own use-divided into thirty-seven books, constituting an abridgment of the science of medicine and surgery up to his time; and, notwithstanding its imperfect state, this work was held in greatest reverence, and was a common source of knowledge among Orientals long after his day.

IIaly-Abbas, a Persian by birth, flomrished fifty years after khazes, and died A.D. 994. II is Almulelic, in twenty volumes, constituted a quite complete system of theory and practice of medicine, which, howerer, was in large measure taken from Rhazes's Continens. It is generally regarded as the best work of any of the physicians of the Arabic Period; it is dirided into three parts - a book on Health, a book on Death, and a book of Signs-and it is interesting to know that the portion devoted to midwifery and obstetrics was in the hands not only of the profession, but also of the midwives.

Avicenna-Latinized form of his Arabic name, Ebn Sina-was born in Bokhara in 980. From his earliest youth he manifested a remarkable disposition for scientific study, and it is claimed that lie mastered the entire Koran at the age of ten years; also that he devoted his entire days and the greater part of his nights to research, master- 
ing philosophy. mathematics, astronomy, and, later, medicine, which he studied at the mirersity at Bagdad, in which eity his talents were chictly exhibited. He was received at court, loaded with farors, and elevated to the dignity of Vizicr, but suddenly fell into disgrace, was deprived of property, imprisoned. and even threatened with exerution. After two years, however, he was restored to liberty, and once more possessed the consideration of the public and the court, becoming the recipient of new honors. Meantime he had given himself up to intemperance, by which his previously robust constitution was undermined, and this. with excesive labor, bronght about his demise at the too early age of fifty-six, in the year 10:37. He was anthor of several books, the chief being the Cunon Medicine, which remained a classic for six centuries, constituting the medical code of Asia and Sancenic Europe; no anthor since Gialen had enjoged so wide and extensive anthority in the medical world; and in the varions merlical schools professor's, for the most part, confined themselves to reading the Canon from their desks, explaining and commenting upon its text. The work was divided into fire rolumes, of which the first two comprised the principles of physiology, pathology, hygiene, and therapentics, arranged to conform to the teachings of Aristotle and Galen; the third and fourth dealt with treatment; and the filth was devoted to the preparation and composition of remedies. Aricenna appears to have surpassed in subtlety both Aristotle and Galen; he was fond of metaphysical speculation, and his works were too much filled ont with subtleties of language rather than with true science. Anthors of this period were fond of torturing in every way possible the writings which they undertook to clit or quote from, and, instead of devoting themselves to original research, wasted time in seeking for rague and hidden meanings. 'That man was most esteemed as learned who could see the greatest subtlety in some passage from 
one of the ancient writers; consequently, that which was obscure or unintelligible was deemed the nost sublime and philosophic. A very brief study of the Canon, for instance, will show this, while in graphic pictures of discine the work by no means approaches those of Aretecus or Alexander of 'Tralles, for Aricenna too often contented himself with mentioning merely a list of symptoms withont indicating in any way their progression, characters, or duration. Undonbtedly just was the criticism of an Arabian poet: "His pluilosophy had no somel foundation, and his medical knowledge availed him naught for the possession of personal health and long life."

Albucassis was born in Kahra, near Cordova, about the begiming of the eleventh ecntury, and is supposed to lave died A.D. 1122, at the advanced age of one hundeed and one. Ile was author of an abridgment, or compilation. devoted to the practice of medicine, the only novelty of which is a small portion devoted to surgery, in which are described certain instruments. He salys :-

"I have detailed briefly the methods of operations; I have described all necessary instruments, and I present their forms by means of drawings; in a word, I have omitted nothing of what can shed light to the profossion. - . But one of the principal reasons why it is so rane to meet a successful surgeon is that the apprenticeship of this branch is very long, and he who devotes himself to it must be versed in the science of anatomy, of which Galen has transmitted us the knowledge. . . . In fine, no one should permit himself to attempt this difficult ant without having a perfect knowledge of anatomy and the action of remedies."

Not a word is said about dissections. however, from which we conchude that they were not tolerated in his time. He resorted enthusiastically to the cautery, and recommended it in spontancous luxations and the commencement of curvature of the spine. He refers particularly to 
instrumental delivery and the extraction of the after-birth, and, when speaking of fractures and dislocations, he remarks: "l'his part of surerery has been abandoned to men of rulgar and uncultivated minds, for which reason it hats fallen into undeserved contempt."

Arenzoar, born in 1113, of a Spanish family which hat many illustrions scions, was instrueted in medicine by his father, and ultimately achiered great celebrity through-

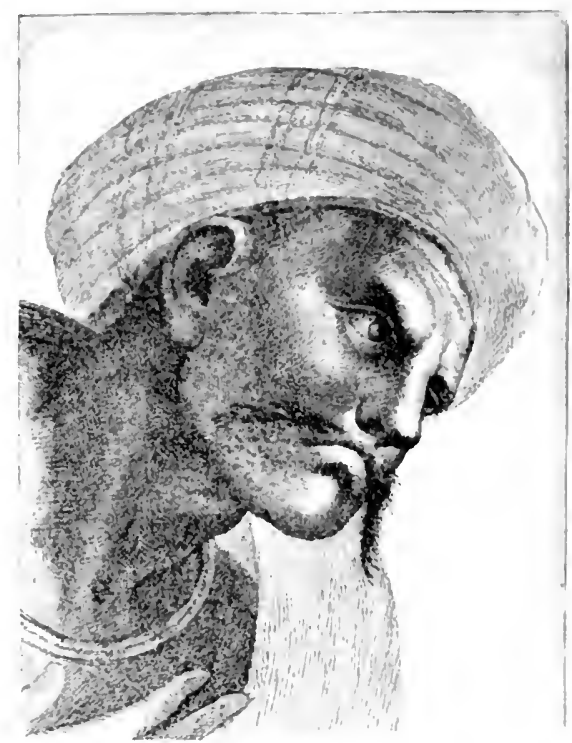

Fig. f-AVERROËS.

(From an engraving of a preture ly Ratiaello in the Tatican.)

ont Spain and Africa; for a time lie lived at the court of the Prince of seville. loaded with honors and presents, and finally was made Vizicr. Among other works he wrote a treatise on renal diseases, in which he outlined the treatment of calculus and described an operation therefor. He died in 1161.

Averroës (as he is generally known, though his Arabic name was Elun lioschil) was born A.D. 1166, in Cordova, 
where his father held official position. After being grounded in philosophy, mathematics, and other sciences he became a pupil in medicine under Avenzoar. The greater part of his life was passed in Serille, where he was greatly esteemed and finally knighted. In 1195 he was called to the court of the King of Spain and Norocco, in Cordova, where he received the highest honors, only, however, through some misunderstanding, to be disgraced; but he soon afterward recovered his former position and dignities. He wrote extensively not only on medicine, but on philosophy, his writings taking throughont a more or less dialectic character. He died in 1198, and from him descended a number of physicians who achieved more or less reputation.

Maimonides, the Jew, was born in Cordova, A.D. 1135. He early devoted himself to the Talmud, and in his extended travels visited Jerusalem; he even founded a school of philosophy in the East, which, however, had only a brief existence. He died in 1204. He ranked higher in philosophy than in medical art, and seems to have been imbued with the methods of his teacher, Averroës, and is generally regarded as a theorist rather than as a practical physician, although he wrote more or less on medical topics, and is particularly remembered for an cssay upon poisons. He was about the last of the Arabians who deserves special mention.

During the period which was nearing its close at the time of the death of Maimonides, the Arabs embraced with much ardor the study of medicine, and translated into their language nearly all the treasures that had been amassed by the Greeks; indeed, the preservation of many of the great writings which would otherwise have been lost is due solely to this fact. Strange to say, however, the Arabians neglected Latin authors, and apparently possessed no knowledge of Celsus or Colius Aurelianus. As religious prejudices prohibited dissections, they were 
obliged to rely solely upon the anatomical descriptions of Galen, and sncceeded in increasing the errors of the orig. inal by inacemrate translations. So far as originality of observation goes. the Arabians were in most respects behind the Greeks; nevertheless, they were the first to differentiate eruptive fevers, to which the latter paid little or no attention. 'The Arabian school also supplied the knowledge of purgatives, such as cassia and mamma, which replaced the drastics employed by the ancients; also the mode of preparation of syrups, tinctures, distilled waters, pomades, and plasters.

While the Arabians were gradually rising by their power. intelligence, and renown, the Greeks were declining in inverse ratio; the genius, comrage, and ancient virtues of the latter arew weaker and weaker, until they seemed on the rerge of extinction. In the medical history of these centuries, in all Europe not under Moslem rule, there was but one man entitled to mention as an anthor in medicine,- - viz., John Actuarius, the son of one Zarbaria. He lived at the close of the thirteenth and the begiming of the fourteenth century; was emplored at Constantinople, his sumame being the honorary title of the court-physicians. He is more commonly known as Zacharia. Of his life we know little, save that he wrote several rolumes, for the most part abridgments or commentaries on the doctrine of Gialen. He laid great stress on the theory of critical days, and sustained his riews by astronomical hypotheses most ingeniously combined. His was the first Greek work in which were mentioned the remedies introduced by the Arabians, yet he has not a word to say of variola, measles, spina ventosa, and other affections fully described by Arabic authors. He held remarkable riews concening the nature of man, whom he supposed to be formed by the union of two contrary sub. stances. - the soul and the body; described somewhat elaborately an imaginary plexus of veins connected with 
the digestive organs, through which the animal spirits were elaborated and pmrified; also, and quite methodically, for his age, he explained the functions of the animal econony and the etiology of disease.

While the clonds that befogged the study of medicine in the Empire of the East thus grew heavier and heavier, we must not be blind to the melancholy spertacle conceming the provinces composing the Empire of the West. Barbarians in swarms, from the forests of Germany and Scandinavia, had swept its varions portions, pillaging, destroying, and reducing to slavery its inhabitants. In southern Europe everything was changed. Each generation witnessed some new and unheard-of inrader, who demanded his share of booty and renown and left a track of desolation behind him. There was a bricf period of order when Charlemagne remited under one dominion these divers races and seemed to have resuscitated the Westem Empire; but no sooner was he dead than its elements, being deroid of affinity, broke apart. Former vassals, no longer restrained by the firm hand of the emperor, made common warfare against his successors and against each other, and for sereral ages there was nothing but a succession of wars and invasions. Feudalism gare some sort of character to this military anarchy by affording repose and, in a measure, security for those who had hitherto been trampled under foot; but learning and the sciences fell into complete neglect, and it was with great difficulty that a very small number of men found within the pale of the church a limited protection that enabled them to devote themselves to the study of medicine and ecclesiastical law. Near the end of the elerenth century, however, the enthusiasm of the crusades whetted anew the turbulent appetite of the Christian barons, and led these lords of western Europe, with their belligerent spirits, to the East, as a result of which people hitherto oppressed could breathe more frecly. A few States recov- 
ered their independence; some semblance of law was established; muncipal institutions were organized, and establishments consecrated to public use were founded and multiplied; finally, in the comse of the thirteenth and fouteenth centuries, the clond which covered the fice of Roman Catholic Europe was in some measure dispersed, and men of talent and eren genius began to appear upon the scene; everything about them being so obsenre, they shone like stars in the firmament. In letters, for instance, there were 1)ante, Petrarch, Boccaccio; in mathematies, Leonard, of Pisa, the first in Emope to understand and employ figures and algebraic characters, although Curier has clamed this distinction for Gerbert, a Benedictine monk of the tenth century, who subsequently became Pope Sylvester II. At this time, although in scholastic estimation medicine, theology, and philosophy alone were fit to entertain the human mind, the natmal sciences were not without oceasional representatives. Roger Bacon was three centuries in advance of scientific reform, and endearored to introduce experimental philosophy, and so fully convinced some of his auditors that they subscribed \&2000 sterling to provicle for the expense of his experiments; this was money most happily employed, since it made possible a number of important discoveries. It is said that Bacon knew the properties of convex and concave lenses, and was the first to conceive of the microscope and telescope; his astronomical knowledge led him to demand a reform in the calendar, which Gregory XIII carried out three centuries later; he had knowledge of gumpowder and its effects, and was, in fact. the wizard of his day; but his boldness and originality drew upon him the enmity of the church, by which he was persecuted and finally condemmed to imprisonment for life upon a diet of breald and water, although he was ultimately released, in 1266, by Pope Clement IV. He wrote extensively, but only fragments of his works exist, since the friars 
believed thom tainted with witchcraft and prevented their publication.

Before and during the time of Roger Bacon the philosophers were divided into two parties, which engangerl in very unseemly and unphilosophic strife. One was termed the Reulist, and believed, with Plato, that ideas are selfexistent and independent of the mind,-in other words, veritable entities; the other, the Nominulist, lect, with Aristotle, that general ideas are pure abstractions formed by the mind with the aid of sensations received from without, without which they conld never exist,-that is, if a being could be imagined withont sensibilities and the power of sensation, such being would be destitute of ideas. These two parties kept up a very active warfare, and enlisted the aid of both ciril and ecclesiastical authorities, the result being persecution of each other, and that general unsatisfactory conflict into which theology and metaphysical speculation always force those who indulge in them.

Now, regarding the condition of medical affairs in the Empire of the West: Down to the serenth century, in Rome, there were court-archiaters who were attached to the retinues of the nobles, and in each large city popular archiaters formed a college charged with sanitary matters, the instruction and examination of candidates, and gratuitous services to the poor. Although there is little definite information available, it is probable that after the ruin of Alexandria much the same medical organization obtained in those provinces as continued under the Greek Empire at Constantinople. Under Arab sway we know very little of what rules or regulations governed instruction in medicine and its practice; and, so soon as one of these countries fell under the rule of the Turks, all scientific institutions seem to have decayed or been discontinued,-or, as Renonard states it: "If we may judge by what still exists to-day in this unfortmnate country ('Turkey), consumed by the power 
of ignorance and despotism, the most complete anarchy followed all older oreanizations."

In southern Europe, however, things lad not gone on quite so badly, although at first barbarons invasion caused everywhere disorder and confusion, and the Christian States of the Westem Empire yet presented after three or four centuries a chaotic condition of affairs. 'The ecclesiastical schools, which were under the care of the chureh, still pursued courses of literary and scientific instruction; in the time of Charlemagne, for instance, the colleges of the cathedrals, and even some of the monasteries, tanght medicine in a rery limited way under the name of phrsics. Thus all the liberal professions-that of medicine included - fell under the domination of the clergy, and priests, abbots, and bishops became court-physicians. The monlis of Momnt Cassin, of the order of St. Benoit, enjoyed for a long time a great reputation for medical skill; and among these in the tenth century was an abbot named Berthier Didier, who became Pope Victor III toward the close of the eleventh century, and one Constantine, sumamed the African. Of the ecclesiastics who from the ninth to the eleventh century were distinguished by the knowledge of medicine, there were Hugues, abbot of St. Denis, physician to the King of France; Didon, abbot of Sens; Sigoal, albbot of Epernay; Archbishop Milo, etc. Even several religions orders of women undertook, to a certain extent, the practice of medicine, and Hildegarde, who was abbess of the convent of Rupertsburg, near Bingen, is credited with having written a treatise on Muteria Merlica.

From the ninth to the thirteenth century the Jews shared with the clergy the monopoly of the healing art. Many of these studied under Arabian physicians, and, though the canous of the church forbade them to in any way minister to the ailments of Christians, they were still called upon in time of need, and even in many instances had access to the palaces of archbishops, cardinals, and popes. 
The education of Christian priests and infidel practitioners embraced really very little, and consisted, for the most part, of knowledge of a few symptoms and possession of a few receipts; books were excessively rare and expensive, capable teachers lacking, and a good medical education out of the question. There was no law nor public regulation which concerned the practice of medicine, and any who desired could enter upon it; while besides the priests and the Jews-which latter stood at the top of the scale-there was a multitude of charlatans of the lowest order, such as barbers, keepers of baths, and even a few women. The morality of this vulgar herd was on a level with its linowledge. I have said the practice of medicine was not regulated by law, yet Theodoric, King of the Visigoths, enacted a statute that no physician should blced a woman of noble birth without the assistance of a relative or domestic; that if a physician in treating a patient or drossing a wound happened to harm a gentleman he should pay a forfeit of one hundred sous, and if the patient died from the operation he should be handed over to the relatives of the deceased, who conld do with him whaterer they pleased; while if he crippled or cansed the death of a serf, he was to be held accomitable only for the loss, and compelled to supply another. This remained in force from the sixth to the twelfth century, and was made to apply chiefly to the practice of surgery, which had been abandoned to individuals of the lowest condition. 'The practice of internal medicine was, for the principal part, the privilege of the clergy, and it is not likely the sccular power ever expected that one protected with the title of priest should be handed over to the relatives of the dead. It furthermore appears that the practice of medicine as dirorced from surgery led to such irregularities in the manners and conduct of the clergy that from the twelfth century popes and councils of the church repeatedly forbade the medical art to those in holy orders or under vows; but that this 
prohibition was often violated is shown by the frequent reiteration of inhibitory laws. During the twelfth century the secular anthority was also affected by abuses. Roger, founder of the kingrom of Sicily, one of the first Clnistian princes of the Niddle Agres, gave special attention thereto, and in 1140 proclaimed that every one who wished to practice medicine must present limself before a magistrate and obtain authorization, under pain of imprisonment and confiscation of goods. Other sovereigns followed this example, and regulating ordinances were gradually established, which nltimately led to the institution of medical firculties and miversity degrees.

During the Middle Ages, in the Empire of the West, arose the School of Salemum, which became so celebrated that, like that of Alexandria, it deserves special mention. The modem rity of Salerno is situated on the Gulf of Salerno, about thirty miles southeast of the city of Naples, with a population of but a few thousand souls. The ancient city stood upon a height in the rear of the present town, where the ruins of its medieval citadel are still to be seen. It first appeared in history 194 B.C., when a Roman colony was founded. was a municipal town of importance, and appears even at this early day to have been a health resort, since Horace informs us he had been advised to substitute its cool baths for the warm ones of Baire. During the stormy centuries following the downfall of the Western Empire, Salemo successively submitted to the sway of the Goths, Lombards, Franks, Saracens, and Greeks, as the ricissitudes of war compelled. Under the Lombards it beeame the residence of the luke of Benerentmm, and, in 1075, when taken by Robert Guiscard of Normandy, it fell to the crown of Naples, in consequence of which in the fourteenth century, the heir apparent of this kingdom took the title of Prince of Salernum.

During the. Middle Ages here flomrished a medical school, important not alone becanse of its celebrity at the 
time, but for its effect upon the medical history of the future. Its origin is obsenre, though it has been ascribed to Charlemagne in 802 ; again, its fomding has been held to be the work of fugitives from Alexandria when that eity was eaptured by the Saracens, 640 A.D. ; some attribute it to the Benedictine order of monks, others to Saracens, ete. The foundation by Alexandrian fugitives is probably conjectural, yet it must be admitted there is some evidence of knowledge of Arabian medicine in Salermum as early as this. Be the origin what it mar, it is certain that the Bencdictine monks exereised a very important influence upon this school, and there is considerable reason to think that it was really originated by them. 'Their monastery of Monte Casino was located about fifty miles the other side of $\mathrm{N}$ ilples, occupying the site of an ancient temple of Apollo; the rules of the order enjoined the care of the sick and treatment by prayer, and St. Benedict himself was credited with performing miraculous cures. The rules which forbade public instruction were gradually discarded, for in the ninth century Abbot Bertharius wrote two books on the art of healing, and by the tenth century Monte Casino had acquired great reputation as a medical school, and was sought by medically-inclined monks from all quarters. A little later (1022) King Henry II, of Bararia, Emperor of Germany, is said to have been cut for stone by St. Benedict himself, who appeared in ghostly form and operated with such skill that on awaking the royal patient found the ealcuhs in his hand, and only the cieatrix of the wound through which it had been removed. Of course, the grateful emperor could do no less than richly endow the monastery, and bestow upon it additional privileges.

Desiderius, the Benedictine abbot from 1058 to 1086 , and in the eleventh century promoted to the papal chair under the title of Vietor III, was distinguished for his attainments in medicine and in music, and founded a new hospital in connection with the monastery; he also com- 
posed four books dotailing the miraculous cures wrought by his pattron saint. It was really within this monastery that Constantine the African, one of the most learned men and the most famous Christian physician of his time, compiled his numerous medical treatises.

Ahout Constantine there is much of romance. He was born in Carthage in 1018 and died in 1085. He visited all the prominent schools of his day in Egypt, Bagdad, Babylon, and even Hudia, and for thirty-nine years pursued the various branches of knowledge away from home. Returning to Carthage, mismuderstood and feared, he was accused of practicing sorcery and compelled to fly to save his life. Disguised as a begrarar he escalped to Salernum, which had been recently captured by Robert Guiscard, and on the recommendation of some royal risitor, who had known him at anothej court, he was made private secretary to Guiscard. His new duties soon became irkscme, however, and he retired to a cloister to devote himself to literary labors. 'These, for the most part, were translations of Greek and Arabic writings, often made verbution and withont credit. Whatever may be said about this lack of honesty, and the barbaric nature of his latin, credit must be given him for reviving the study of Hippocrates and Galen in France; and he is generally credited with being the first to introduce into Europe knowledge of Arabian medicine.

From Monte Casino the Benedictines at an early day spread to Salerum, where, by the middle of the tenth century, three monasteries were established, in all of which were kept holy relics. It now appears that, although there may have been some previous institution of learning at this point, and possibly eren medical teachers, the real organization of a regular school of medicine was due to the Benedictines. In the ammals of Naples of the middle of the ninth century the names of Salernian physicians are mentioned; and it is known that toward the close of the tenth 
century Archbishop Verdun visited Salermum for relief from vesieal calculus, and there died.

The earliest medical writings of this school which have been preserved are found in the Compendimm Sulernitanm, discovered in manuscript form in 18:37; and among the more prominent authors quoted are: Petronins, who wrote about 1035; Gariopontus, who wrote abont 1040; Bartholomeus, Ferrarins, and Afhacins, - the latter a disciple of Constantius Alricanus.

The preaching of Peter the Hermit, which marked the close of the eleventh century, was followed by an outburst of crusading enthusiasm that quickly converted Europe into a vast canp, and Salemum, being situated upon the highroad to the East, was benefited in no small degree and its reputation as a medical school materially enhanced; likewise its teachers gained in experience as regards military surgery. In this way it became a farorite resort for crusaders when disabled, wounded, or diseased. Robert of Normandy, son of the conqueror, returning from the Holy Land, remained here for some time with a poisoned wound in the arm, received in 1097 at the siege of Jerusalem, and it was decided it could be healed only by sucking out the poison, a process deemed dangerous to the operator. History declares that Robert's wife, daughter of Goeffrey, Larl of Conversana, being denied permission, took advantage of her husband's monconscionsuess during sleep to withdraw the poison, when the wound speedily healed. At the time of the departure of Robert, hastened by the death of his brother William, Joln of Milan, the then chief of the medical school, presented him with the famous Regimen Sanitatis Salerni, said to have been composed largely for Robert's benefit. 'This was a Latin poem that enjoged most unexampled popularity for many generations, and was the vade mecum of well-educated phrsicians for centuries. It is said to have passed through two hundred and forty different editions, and that more than one hundred 
manuscript copies are to-day to be found in rarious European libraries. The latest English version was published by Professol Ordronaux in 1871 . A sample is here submitted :-

\footnotetext{
"silnomo"s school in conclave high mites To roumsel Eumlaml's king, amd thus indites:

If thou to liealth and vigor would st attain, Shum miglty cares; all anger deem profane; From heary suppers and much wuse alstain; Nor trivial comnt it after pompens fare To rise from table and to ticke the air. Shun ulle nowmlay slumbers. nor lelay The merent calls of mature to ohey.

These rules if thom wilt follow to the end, Thy life to groter length thon may"st extend."
}

During the twolfth and thirteenth centuries the glory of the School of Salerno reached its zenith; it was the most famous school of medicine in Emope, and was fostered by various kings. 'The celebrated Jew, Benjamin of Tulela, traveling from Spain to India, visited Salernum in $116 t$, and called it the "principal university of Christendom." Ealy in the twelfth century flourished Cophon, Archimatheus, and Nicholas, smrnamed l'repositus. all of whom were distinguished teachers. The latter published a work known as Antidotarium, which was for several centuries the standard pharmacopocia, and which contained a table of weights that corresponded rery closely to those of the modern apothecary. The younger Cophon, who has been confounded with his father (as both seem to have written extensively), wrote two treatises, - one on the anatomy of the hog, the other entitled Ars Merlendi. 'The first is interesting as the only anatomical treatise of this school which has been preserved, and is an index of the degradation of anatomical science of that time.

'The names of John and Matthew Platearius are of frequent occurrence in the records of this school, and have given rise to considerable confusion; the former is supposed 
to have been the husband of 'Trotula, a female physician, of whom I shall have more to say later.

Bernard the Provincial, who seems to have escaped the notice of most historians, wrote about 1155, and his commentary offers much interesting information concerning the therapentics of the day; he formulated a large number of recipes to enable the sick to escape the ommipotence of the apothecaries, and recommended wine for the delicate stomachs of the more exalted of the clergy, and, inasmuch as these stomachs did not bear medicine well, he directed, in accordance with the practice of Archbishop Efanus, that emetics should be prescribed "fter meals, when their action is less injurious and more agrecable; he advised roung men and women tormented with love which they could not gratify to tie their hands behind their backs and drink water from a ressel in which a red-hot iron had been cooled. Indeed, his work is full of curious information and advice, and is not without therapentic interest.

A name which figures largely in the history of this school is that of Magister Salernus, about which there is great uncertainty; it is not positively known whether this refers to a particular person or is a generic name corering various individuals. The name has been mentioned as that of one of the four reputed founders of the school; it is positive that there are certain treatises which bear this name, which give an appearance of authenticity to it as an individual title.

In the latter half of the twelfth century lived John of St. Paul, one of the teachers of Gilbert the Englishman; also Musandinus, who left a curious treatise on dietetics; and Urso, who wrote on the pulse and on the urine. Here in 1190 resided and studied a certain Alcadinus, from Syracuse, whose knowledge of philosophy and medicine was such that he acquired great reputation, and was made a professor; he even composed latin medical poems.

Just at the close of this century flourished Egidius. who 
studied at Salernum, and also at Montpellier, where a school of medicine had been founded in 1180; he was phrsician to Philip Augustus. of France. and became professor in the University of Paris. 'Three treatises, all in Iatin hexameter, are ascribed to him. A contemporary was Johames Rogerius, of Palerme, a graduate of Salernum and anthor of sereral works.

Early in the thirtecnth century flourished Roger of larma, one of the most distinguished of the alumni of this school and the earliest pioneer in modern surgery; his work on this topic, familiarly known as Rogeriena, enjoyed the greatest reputation in its day, and was for a long time the surgical text-book of Italy; his predilection for poultices and moist dressings in the treatment of wounds, abscesses, and ulcers became, in the hands of his successors, the distinguishing feature of the surgery of Salernum in opposition to the school at Bologna, where Hugo Di Lucca and Theodoric (his great rival) contended for the superiority of the dry treatment. Roger was also the first to use the term setom, and to give practical demonstration to this means of derivation.

Roland of Parma, a pupil of Roger, and a surgeon of great distinction, became professor at Bologna, and wrote a treatise on surgery, which was, for the most part, a commentary on the works of his master. The treatise of Roger and that of Roland furnished the basis for a work entitled The Treatise of the Four. Mlasters, supposed to have been written about $12 \%$, and manuscripts of which have been long known in various European libraries. It is divided into four books, displays no little surgical ability, and from its title wonld appear to have been the joint composition of four teachers; indeed, it was long attributed to Archimatheus, Platearius, Petro Cellus, and Afflacius, though it is now pretty generally understood to be the product of but a single pen and its author most likely a Frenchman. The ascription of anthorship to four masters was probably for 
the purpose of increasing its weight and authority, and it constituted a reliable exposition of the surgery of Salermum in its day. It is quoted quite freely by Guy de Chauliar, who was the restorer of French surgery in the fourtcenth century, and occasionally by later writers.

Another of the distinguished Salemian physicians of the thirteenth century, one highly esteemed by Frederick II, was $\mathbf{J}_{\text {oln }}$ of l'rocida, who also was active in producing -if not the real anthor of - the massacre of the Sicilian Vespers, A.D. 1282. In a dispute concerning the question of the two Sicilies he embraced the canse of l'rince Nanfred, for which he was banished by Charles of Anjou, and took refuge at the court of Peter III, of Arragon, by whom ine was created a baron; and he was influential in persuading the latter to assert his claim to the throne of Sicily. By various intrignes at different courts he succeeded in organizing an alliance, which betrayed its existence in this massacre, and finally resulted in the overthrow of the French in Sicily and the transfer of the island to the crown of Spain. He was author of at least two treatises devoted to medicine and philosophy.

Other writers of the School of Salernum were: " learned Jew of Agrigentum known as "Farragus," Matthew Sylvaticus, Grapheus, and Cappola. About the middle of the fifteenth century flourished Saladino, famous as an authority on materia medica.

It is of no small interest that now, for the first time in history, women began to figure somewhat prominently as writers, practitioners, and even teachers of medicine. About the middle of the eleventh century appeared a work, entitled De Mulierinm Passionibus, attributed to the before-mentioned Trotula, wife of John Platearius, which has descended even to these days. There is nothing in the work to indicate the name or sex of the author, who is invariably spoken of in the third person; consequently Trotula's connection therewith has often been disputed. 
It mentions a certinin "uque mirubilis," composed largely of brandy, which spirit is said to have first been employed medicinally by Thaddeus of Florence, who died in 1295; there is also an account of a patient who wore spectucles! The diseases of women and children are also largely dealt with. The work is undoubtedly an anonymous production of the elerenth century, disfigured by additions of a later day, and ascribed to 'Trotula, perhaps. because of the celebrity that attached to her; at all events, it is the earliest work ascribed to a female physician, and thus possesses special claims to interest.

Later we read of Sichelguada, wife of Robert Guiscard and a gratuate of Salernum, who endeavored to poison her step-son, Bohemond, in order to secure the succession of her own child. 'This infimous plot was furthered by some of the Salernian physicians, and thwarted only by the prompt action of Guiscard, who swore he would slay his wife with his own sword should the malady of Bohemond prove fatal.

Certain other female physicians of this period are mentioned, notably Abella, who, in spite of the modesty that is supposed to hedge about her sex, produced in Latin hexameter a work entitled De Natura Seminis Hominis. Mercuriolus, in the fifteenth century, produced treatises on the curc of wounds, pestilent fevers, and on the nails. The most celebrated of all, however, appears to have been Calenda, who lived during the reign of that notorious profligate, John II, of Naples (1414-1435), and who was particularly distinguished for her personal attractions. She graduated with great honor from the school at Salernum, and soon after, in 1423 , married a nobleman of the court, which perhaps accounts for the fact that she never exercised the privilege of authorship. A little later, Margnerite, of Sicily or Naples, also a Salemian graduate, acquired an extended professional reputation, and was licensed to practice by Ladislaus, King of Poland. 
Daremberg informs us that there were numerous female physicians at Salernum, much sought after because of their talents, and, moreover, highly esteemed by the professors of the school, who freely quoted the writings of their fair pupils and contemporaries; further, that they employed ointments in paralyses; fumigations, vapors, and antimony for conghs; and lotions of aloe and rose-water for swellings of the face; they combined scientific knowledge with facetious playfulness in a mamer peculiar to the sex, in that they tendered unsuspecting beaux bouquets of roses doctored with powdered euphorbium, and hugely enjoyed the forced stemutations of their rictims.

It will thus be seen what a wide-spread and long-continued influence the school of Salemum exerted. At first physies and philosophy were the principal branches tanght, but later the other sciences were cultivated. 'The Emperor' Frederick II united the different schools of the city into a university, - a term, however, that, as then applied, appears to have corresponded to what in the nineteenth century is understood by corporation. The emperor likewise published several decrees which revised the duties and privileges of practitioners of medicine and surgery in his lingdom, and, in 1224, ordered that no person shonld practice within the two Sicilies until examined by the faculty of the university and licensed at the royal hands; further, practitioners were compelled to derote at least one year to the study of anatomy. The faculty at this time consisted of ten professors, whose salary probably depended upon the number of pupils. A candidate for graduation was required to present proof of majority, of legitimacy of birtl, and of proper duration of preliminary study, and then was examined publicly in the Synopsis of Galen, the Aphorisms of Hippocrates, or the Cunon of Avicenna. On passing he swore to conform to all the regulations hitherto obserred in medicine, to give gratuitous treatment to the poor, and to expose all apothecaries 
detected in adulterating drugs. A book was then placed in his hands, a ring npon his finger, and a laurel crown "pon his head, when he was "dismissed with a kiss." The degree conferred was that of "Mlugister," - the modern title of Doctor being at that period employed almost exchusively to designate a public teacher or professor.

But the watchfulness of King Frederick was not confined alone to the regulation of medieal study within lis kingrlom. 'The number of professional risits, and the recompense therefor, were fixed by law. Every physician was compelled to risit his patients twice daily, and even once at night as well, if summoned, and for this attendance was permitted a daily fee equivalent to fourteen cents for patients within the eity, while for calls withont the eity the largest legal charge was one dollar and thirteen cents, provided he paid his own expenses

The earlier teachings and practice of Salemum were a curious mixture of methodism, dogmatism, and superstition. The latter may be better understood when it is recalled that the practice of medicine for an extended period was confined almost exchusively to ecclesiastics, who by their very education were prone to superstition and upheld the efficacy of charms and relics, and the active intervention of saints and martyrs as well as the myrmidous of evil; hence arose many of the conflicts and absurd notions peculiar to the period. The prevalence of the doctrine of medical methodism was due to the character of the writings most accessible to students of that day,such as those of Colius Aurelianus and others; and it is curious that Celsus, the most elegant of medical authors, was never popular among medical monlss. The Hellenic language having almost disappeared from Italy by the sixth rentury, the works of the Greck authors had become a sealed book to a vast majority, even of the better educated; hence the purer sources of medical knowledge were not available. Although the school of Salernum, at a later 
date, prided itself upon its devotion to the "Father of Medicine," the Hippocratic writings were not known at this period; and, when Constantine the African, by the translation of Arabian works, introduced a new element into the Salernian school, he ingralted upon its medieal teaching a form of doctrine which found a congenial atmosphere, in which it throve vigorously, while, at century later, the translations of Gicrard of Cremona gave a stronger impulse to the growth of Hippocratic medicine than to Hippocratic doctrine.

From the Commentury of the Four Mrasters we learn that Salernian practitioners recognized the diagnostic importance of nausea, voniting, and the flow of blood from the ears in injuries to the head; that they resorted to the trepan for depressed fractures and the relief of intracranial extravasation; that hernia cerebri was treated by pressure and canstics; that ligatures, both above and below the opening, were applied for the treatment of wounds of the carotid arteries and jugular veins. It was advised to decline patients suffering from wounds of the heart, lungs, diaphragm, stomach, or liver, in order to aroid the disgrace of losing them; and in penetrating wounds of the intestines and in those complicated with protrusion of the wounded gint instruction was given how to envelop them in the warm abdomen of a slaughtered animal until natural color and temperature were restored, and then to insert a cannula of alder-wood in to the wounded intestine, which was to be neatly closed and stitched; finally, the protrusion was to be carefully washed with warm water and returned into the abdominal carity, cnlarging the opening for this purpose, if necessary. Also was advised the extraction of diseased teeth; and the operation of lithotomy was described with considerable care. Compound fractures were to be treated with splints. On the whole, this commentary of the alleged Four Masters is the most interesting and ancient Salernian work which has 
been preserved, and is well worthy the attention of even modern surgeons.

Such was the school of Salermum in its prime, during the twelfth and thirteenth centuries. My readers will not have failed to note how few names have been mentioned which are prominent in medical history, and how few improrements were made in medical art by those who have been mentioned. One naturally inquires, then, what was the source of the wide-spread fame of Salerno as a school, since it was distinguished neither by notable discovery in science nor by celebrated teachers, and the predominant element was doubtless one of obstinate conservatism and unswerring derotion to ancient doctrines. Fomnded during the dark period of the Middle Ages, at a time when ignoranee, bigotry, and superstition prevailed, it preserved, amidst the gloom that had settled upon Europe, a few rays of that intellectual light which had shown so brightly in the golden ages of Roman history. These rays, made more conspicuous by the intellectual night which they barely illumined, were a beacon for men who were groping for more light. 'Thus the name of Salernum became s!nonymous with intellectual adrancement in later ages. As the parent and model of our modern university system, Salermum yet deserves, in a measure, to enjoy the esteem of a numerous scholastic offspring. At a time when priests were particularly active in passing off rudimentiry linowledge for the science of healing this school began to secure all information possible from the laity for the progressive development of medicine. It began, in other words, to hold aloof and then to break away from the fetters of a funatical church. Its decline, too, was as rapid as its career had been brilliant. One very serions blow was struck when, in 1224, Frederick Il founded the University of Naples and forbade Neapolitan subjects to seek instruction at any other university. The next year a revolt in the city provolied the closure of the 
schools of Bologna, which were, howerer, opened again two years later. Within a short time the miversities of Naples, Montpellier, l'adua, Paris, and Bologna all entered into a contest for pre-cminence with a rivalry which was not always generous. In 1224 , it is said, the latter minversity had no less than ten thousand students. Happily, howerer, the period of the Renaissance proved to be one of emancipation from the fetters of ignorance and superstition, making an appeal for liberty which the conservatism of Salernum conld not brook. Roger Bacon, in Fingland; Lanfinc and Guy de C'hauliac, in France; Mondino, at Bologna, and Saronarola, at Padua, found no rivals at Salermum to successfully contest their fame. 'Thus this ancient school fell behind the age, and in a short time sank into a mediocrity which was scancely brightened by the reflection of a departed glory. In $13+2$ Robert I renewed the decree of Frederick II, which closed all the schools in his kingdom save those of Naples, but excepted Saleruum solely because of its antiquity and the traditions of his predecessors. In 1+13 King Ladislaus excepted the Saleminu alumni and professors fiom all taxes, duties, and tribute. In the middle of the fourteenth century the poet Petrarch speaks of the school as a memory of the past; but its last appearance was in 1748 , when a dispute at Paris relating to the rank of physicians and surgeons was referred to Salerno's unirersity for arbitration and final decision. In 1811 a formal decree reduced this parent of all European universities to a mere grmmasium or preparatory school; and now one may wander throngh the strects of the modem town and among the ruins of its ancient predecessor and seek in rain to trace some reminder of those who were illustrious during some of the most terible ages in the world's history. No echo of tradition, no stone of ancient edifice, no library preserving precious manuscripts, not even an edition of the old Salernian regimen, in the whole city; in fact, none now so poor as to do it reverence. 


\section{CII.IP'TER IV.}

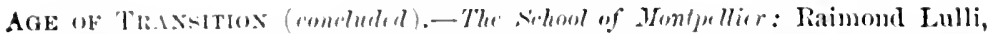

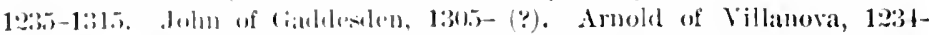

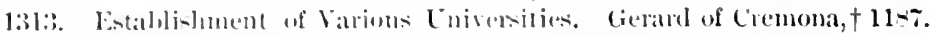

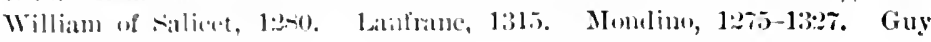
de Chandiac, l:301-1:30.

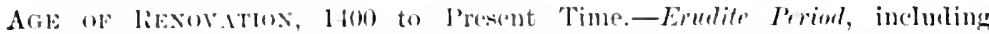
Fifteenth and rixternth Centuries. Thomals Linace, 1t61-15:2. Sylvius,

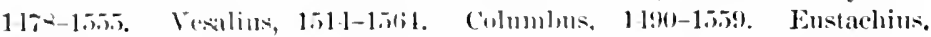

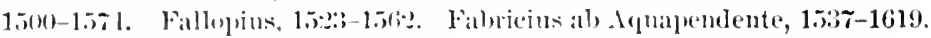

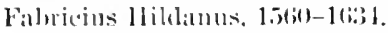

Althoegis I have taken up so much time with an account of the school of Silemum, a few words must be deroted to the school of Montpellier, which was second in time and in importance among the great influences in the culture of western Europe. 'There was a time when to have studied there lent a special halo of glory, for, being near the soa, and in the vicinity of thermal baths, even so early as A.D. 1153 it was famous as a school of medicine; moreover, those who presided orer it did not lapse monconditionally into medieval philosophy, with its bewildering subtleties. It is said to have been fomded A.1. 738, but first mention of it as a source of medical education occurs in $113 \pi$, when Bishop Adelbert II, of Mayence, visited the city to listen to its medical teachers. A faculty of philosophy was added in 124:2, and one of law in 1295. Within the walls of the city sojourned both Christians and Jews, the latter being sulject directly to the civil authorities, and particularly esteemed as translators. One of the most famous of the sons of Israel was Profatius Judicus, who became a rector of the faculty.

Prior to 1370 , when the university became subject to the kings of France, it was under the control of the Pope; and then, as now, the school of medicine was the chief ornament of this ancient seat of learning.

One of the most illustrious and famous pupils of (86) 
Montpellier was that religious mystic and alchemistic visionary, Raimond Iull, or Lulli, a would-be transmuter of metals and seeker for the philosopher's stone. Born in 12:34, at the age of thirty he began to see visions, and was thereby roused from an atheistic tendency to soon become wonderfully pious; ultimately he entered the order of Minorites, studied Arabic, and appeared as a missionary in Africa, seeking to convert the Saracens-who, however, declined the honor, and finally (in 1315) rewarded his zeal by stoning him to death. Beside works on alchemy and theology, he wrote on medical subjects, and, like all great minds of the period, passed among the common people as a sorcerer in leagne with the devil. Nevertheless, he was a notable figure in his age and country.

Quite celebrated became the compendium of Gillert of England (1290), which contained the same speculative nonsense, the same polypharmacy, and the same superstition as other works of that time; what little it contained of value was taken largely from other writers. While this Gilbert, often known as Gilbertus Anglicus, was not the first English writer on practical medicine, he wats the earliest whose works have been preserved.

Still more famons was John Gaddesden, physician-inordinary to the King of England, professor in Merton College, Oxford, who wrote the famous treatise linown as Rosa Anglica, which appeared between 1305 and 1315. This treatise was characterized by mysticism and disgusting therapentic measures, and tainted by medical avarice, superstition, and charlatanry. Gaddesden was, perhaps, the first to formally recommend the "laying on of hands" by the ling for the cure of scrofula (first performed by Edward the Confessor-1042-10.56), whence comes the ancient name for this disease,-i.e., "king's eril." $*$

*A special "Service of Healing" was used in the English Chureh under Henry VIII, 148t-1509. 
Arnold de Villenenve (1:34-1:31:3) studied seren years at Montpellier. twenty years at l'aris, visited all the universities in ltaly, then went to spain to lery on the Arabian authors. He wrote on medicine, theology. and especially on chemistry-in which art he obtained great renown both as an anthor and teacher. 'To him is due the discovery of spirit of wine, oil of turpentine, aromatic waters, besides several preparations of less note: and the introduction of chemical compounds into therapenties. His was a very stiring life, for he traveled extensively; he became a teacher at Bologna, and physician to Peter III, of Amagon. Shortly hefore his demise he went to Paris, having fallen under the ban hecause of a declaration that papal bulls, far from being sacredly inspired, were human works, and that acts of charity were dearer to God than hecatombs, ete. He finally perished by shipwreck, but the spirit of funaticism followed lim after death, for his volumes were condemned by the Inquisition, because they commended experiments rather than mere speculations. In spite of his general honesty in accordance with the spirit of the times he inculcated deceit in medicine, and one of his declarations is: "If thon canst not find anything in the examination of the renal secretion, declare that an obstruction of the liver exists. Particularly use the word 'obstruction,' since it is not mulerstood, and it is of great importance that people shonld not understand what thon sayest." He was one of the first to administer brandy, which he regarded as the elixir of life-whence the modern Eau de Vie.

Connected with this school, also, or well known as having studied there, were many men whose names became more or less famous-among them John Arden, who settled in I.ondon abont the middle of the fomrteenth century; Vinario, a contemporary of Guy de Chauliac; and the well-known surgeon and anatomist Hemi de Mondeville, who was a teacher of Guy de Chanliac. But an idea of the doctrines prevalent in the medical literature of this part 
of the world, at this time, may be had from the fact that most writers chose titles for their works after the style of ballad singers: for instance, those describing the plangue and venereal diseases were called Flovers and Lilies of Medicine; the Rosa Anglica of John Gaddesden was another example. Matters had arrived at such a pass, indeed, that men of science no longer hesitated to confess superstition and mingle it openly with deceit, to oppose the interests of the most needy, and to extort from their fellowcreatures fees in proportion to their supposed ability to pay.

In the time of Charlemagne each cathedral possessed a school in which were taught arithmetic, theology, singing, and sometimes medicine; the Episcopal College had medical teachers who gave advice and dressed wounds at the doors of the Church of Notre Bame, Paris; but when the medical profession had been divorced from the sacerdotal by councils and popes, many of these cathedral schools closed. In order to preserve the juristiction which they for a long time had exercised over the learned professions, many were erected into universities, and thus the clergy gave instruction in philosophy, theology, and later in medicine. During the thirtcenth century arose many of the great universities in Europe, notably those of Bologna, Padua, and Naples, in Italy ; of Paris, Montpellier, and Toulonse, in France; of Valencia and 'Tortosa, in Spain; of Oxford, in England. Pope Innocent III by papal bull guaranteed that the professors and students at Paris should be exempt from all excommunications sare those which emanated directly from the Holy See; French sovereigns conferred many privileges upon the unirersities, and soon the members of the University of Paris formed practically a second city, with its own laws, customs, police, citizens, and magistrates. Still, howerer, all science belonged to the clergy, and its teachers, though remored from the cloister, were none the less Roman Catholic; so that the popes reigned over the people through the parish clergy, 
and over the latter by the clerical teachers and professors. Nevertheless, in all caudor it must be acknowledged that these studious men, thus assoriated together for mutual instruction and emulation in learning, contributed, in a large measure, to elevate Christian civilization above all others, thongh several generations were required to secure the results calculated to make men celebrated; hence the early periods of the universities dereloped rery few names. Many were conspicnons by their love of instruction, but not by originality of rescarch. Men undertook expensive and wearisome royages without eneouragement or hope of reward, simply to obtain some rare manuscript or to hear some renowned profescor; and they appeal to us of the ninetcenth century by their derotion, il not by the results of their work.

Among the somewhat scattered and more or less eminent men of this period was Gerare, of Cremona in Lombardy, a man of great purity and studiousness, who arduously pursued all that Litin anthors conld teach him, and, not being able to proeure in Italy certain manuscrijts which dated liom the time of P'tolemy, determined to go to 'loledo in search of an Arabian translation. At this time he was marequainted with Arabic, but soon mastered it, and-armed with this powerfinl resource, which no other physician had possessed since the time of Constantine the African-he comld not see so many Arabic works deroted to all branches of science as were gathered at the Spanish University withont a desire to translate and transmit the same to his own country; hence he gave the remainder of his life to this work. He rendered into Latin the treatises of Hippocrates and Galen, of Serapion, and of all the famous Arabian authors from the time of Rhazes, including the Crmon of Aricenna and the work on surgery by Albucassis. He died at the age of seventy-three, in 118\%, at Cremona, and left all his books to the monastery of st. Lucy, within whose walls he was buried. 
William of Salicet, born at Piacenza in the first yars of the thirteenth century, became a professor in the University of Bologna, and later at Veroni. He wrote extensively on medicine, and earned a reputation as a surgeon that preserves his fame to the present day. It is clained that his status in medical literature depends, in large measure, upon the fact that he was, perhaps, the first to refuse slavish obedience to preceding anthors, preforring, instead. to draw upon the results of personal study and experience. Ife died in 1280.

lanfianc, or Ianfranchi (according to whether one prefers his French or Italian name), studied muder William of Salicet. Of his early life very little is known, save that he practiced surgery in Nilan at the time of the great dissension between the Guelphs and Glibellines, and, for attaching himself to the weaker party, was exiled and forced to seek an asylum in France; he resided in Lyons for several years, and here wrote a work on minor surgery; in 1295 he went to Paris on the invitation of the faculty of medicine, opened a course on surgery which met with great success, and then published a second and larger treatise on the subject. It is said of him by Malgaigne that, less from his fault perhaps than that of his age, after his death (about 1315) surgery began to decline. From the time of Brunus, who practiced in Padua in 1250 , the barhers had done the scarifying and bleeding. After the time of Lanfranchi there were others who applied leches and often canteries, and even the women meddled with surgery and in all operations competed with the barhers; the lay surgeons held themselves rivals to the clergy. Ianfianchi inherited from his old master, William, an arersion for them all, and often had to contend with uneducated and incompetent laymen. Clerical surgeons regarded operations as beneath their dignity; and Lanfranchi, who deplored this condition of affairs, confessed he had sometimes bled with his own hands, but had never operated for ascites, hernia, cataract, or stone. 
John Pitard has descended to fime not as a writer, but as the founder of the surgical schools of St. Côme and St. 1)amien, which occupy so eminent a position in the surgical ammals of France. In 1306 he was surgeon to the King of France, Philip le Bel, and the sworn surgeon of Chatelet. 'The Collegre of 'St. Côme, in 1311, was only a little brotherhood of lay-surgeons, who gradually grew in importance as the result of the obstinate strugghes sustained,-on the one hand, against the ficulty of medieine, and, on the other, against the barber-surgeons. Malgaigne has, with great patience and clearness, shown that the importance of this body of men has been greatly exaggerated by historians; he has traced their various turns of fortume from becrinning to end; I shall have occasion to consider them again farther on.

Mondino, sometimes known as Mundinus, born in 1255. hecame a professor in the University of Bologna, and died in 13:27. He was the author of a celebrated treatise on anatomy, said to have reached twenty-five editions, and which was the first of its kind since Galen. 'This seience had been greatly neglected; in Salernum, for instance, they were, for a long time, contented with the treatise of Copho on the anatomy of the hog, and most of the anatomical knowledge of the age was apparently derived from this sonrce; Mondino resurrected the study and pursued it with interest and enthusiasm, though under the greatest difficulties. His works for more than two centuries, along with the writings of Galen and the Arabic authors, served for anatomical demonstration, although very incomplete,-as witness the statement:-

"Beneath the veins of the forearm we see many muscles and many large and strong cords, of which it is not necessary to attempt the anatomy on such a corpse (i.e., a recent one), but on one dried in the sun for three years, as I have shown otherwise, in developing the 
number and the anatomy of those of the superior and inferior extremity."

On the other hand, he took the opposite course to discover and demonstrate the nerves, and advised maceration in ruming water. It required almost superhuman boldness to substitute demonstrations on the human cadaver for those upon swine, yet this was done by Mondino ; and at the time the prejudice against dissection was so gencral that for more than a century after Mondino-who died in 1327-no one dared, at least publicly, to emulate his example. It was in the year 1315 that he publicly dissected the bodies of two women in Bologna. Anatomical study was further complicated at this time by certain bulls of Pope Boniface VIII, forbilding evisceration or boiling or cooking any part of the human body; these deliverances were really aimed, not against scientific investigation, but at the absurd custom introduced by the crusaders of cutting up and boiling the bodies of their relatives who died in infidel comntries, in order to send them home for burial in holy ground; nevertheless, the papal injunction certainly operated to discourage and prohibit anatomical dissection, since nearly two hundred years later the University of Tübingen was obliged to apply to Pope Sixtus IV for permission to authorize dissection.

Guy de Chauliac, born in Gévandan about 1300. was the most famous physician and surgeon in Christendom during the Arabic period. He studied at the cathedral college of Mende, which at that time was quite celebrated, and was taught medicine at Montpellier under the best masters of his dar. It is probable, also, that he stuclied in Paris, and certain that later, in Bologna, he saw dissections made. Dissatisfaction with the writings of the ancients and the knowledge which lie obtained at the schools stimulated his own powers of observation, and he became, in every respect, an original student and acquired 
a degree of erudition far more extended than that possessed hy any of his contemporaries. He practiced in rarious places, longest at I yous; and finally entered the srvice of l'ope Clement VI, at Arignon, and probably enjoyed the same honor muler Innocent I and Crban V; when the latter was mate pope, in 13602, de Chanliac herame his chaphin. or chapel-realer. In 1363 he published a work on surgery called The Inrentory, upon which his fume chicfly rests, though several other volumes cmanated from his pen. None knew better than he how to unite respect for the ancients with justice toward contemporaries, and he rited a large number of Greek, Alabian. and Latin anthors, some of whom are now nttelly unlinown. 'The scionces, he declared, are "created by snccessive adrlitions; the same man cannot lay the fomudation and perfect the superstructure. We are as childien carried on the neck of a grant; aided by the labors of omr predecessors we see all that they have seen, and something beside." In tracing the character of a sureon he recommends that he be "learned, expert, inaconions, bold where he is sure, timid when in doubt, aroiding bad cures and practices, being gracious to the sick, gencrous and complassionate, wise in prediction, chaste, sober, pitiful, and merciful; not covetous nor extortionate, but receiving moderate fees according to the circumstances of his paticnts, the chanacter of the case, and his own dignity." "Nerer since Hippocrates," says Malgaigne, "lats medicine learnod a language stamped with such nobility and in such few words." Although a finllower of Galen, in anatomy he insisted on the necessity nif dissection, and proposed to make use of the corpses of executed criminals for this purpose. The drawings made hy Henri de Monderille were known to him; he divided alricesses into hot and cold. although among the latter he includer colema, tympanites, dropsy, scirluus, and other conditions. In prictice he was more timid, yet more 
active, than Lanfranchi, who never cut for stone, but left that operation to the traveling surgeons. De (hamliac: described it as he had seen it performed; he opened the abdomen for dropsy, did not hesitate to attempt the radical cure of hernia, and operated for cataract. The plagne which raged during the fourteenth century and depopulated the known world of one-fourth of its inhabitants, twice appeared in Avignon while Guy de Chanliac was a resident there-and he aclinowledges that nothing but shame prevented him from flecing. He remained at his post, visited the sick, and was himself attacked and left for dead. "In this frightful position he had sufficient presence of mind to follow the peculiarities of his case, analyze his own sufferings, and to give a deseription of them wortly of Hippocrates" (Renouard). His work soon became the surgical code of Christendom, and was commented upon and translated into all tongues, remaining for a long time a classic, and even at this day it preserves much of its interest as representing the condition of medical science at the close of the Middle Ages; moreover, its literary style was much superior to that of any of his contemporaries, all of whom wrote very barbarous Latin. He died about 1370.

With the death of de Chanliac terminates our interest, not merely in the Arabian physicians and those who were intimately connected with them, but in the so-ealled Arabic Period. It may be added, in passing, that the followers of Mahomet, like those of Christ, erected by the side of each of their mosques a school, and often a hospital, endowed with more or less generosity by caliphs or the wealthy, who hoped to purchase redemption and eternal happiness by such liberality.

A certain number of religious orders or communities were established during the Middle Ages to give succor to the deserving sick, the most widely known being those of St. Mary; St. Lazarus; St. John, of Jerusalem; and the 
Danghters of God. 'To be sure, some, through the endow. ment of the opulent, beeame rich beyond all reason, and departed from their primitive purposes, and thus not only excited the coretonsness of monarchs, but had even the temerity to resist their authority. This compelled, every now and again, a suppression of some order or institutionpartly, perhaps, for laxity of morals, and partly because of their turbulence. Of this period it may be said that charitable zeal for the sick was never more pronounced; princes, bishops, and popes gave examples of devotion by dressing with their own hands the nlcers of lepers-and leprosy was in those days a frightful disease, having been contracted by the crusaders in the Orient, and everywhere spread as they returned, being, moreover, farored by the miserable umcleanliness which was then so common. Ignorance, dread, and fear rendered this disease worse than usual, and it was confounded with other maladies less formidable. It has been estimated that in the fifteenth century Europe harbored no less than nineteen thousand lepers; and that the disease was a great terror is manifest $b y$ the excessire cantion taken against its spread: its rictims were forbidden to enter cities, and on the highway were compelled to stand aside lest they should taint passers-by with their breath; even a healthy person conricted of being touched by a leper was banished from society; any infraction of these rules was pumishable by death. It will thus be seen what depth of genuine humanity it required to have anything to do with one of these outeasts.

Another institution prevailed widely during these dilys,-namely, public baths, which were established in nearly every city and increased to such an extent that in the fifteenth century the bathers of Paris constituted a powerful brotherhood, so powerful, in fact, that Jacque Jespars, physician to Charles VII, and one of the most renowned professors of the faculty, for speaking openly 
against the abuse of public baths, was obliged to leave the eapital to avoid persecution.

A study of the general history of the Arabic Period reveals that the Arabs, previously obscure and mucivilized, emerged rapidly from the demi-sarage state, and took the first rank among the polished nations of the world. During the earliest portion of this period these people were religions vandals and destructive fanatics, but later embraced with enthusiasm and persistence a study of the humanities, and endeavored to repair their early ravages by collecting the débris of the literary and scientific monmments of Greece; but, though they cultivated medicine with zeal and success, they added little to the Greek treasures. Later, Arabia was overum by hordes from the deserts of Tartary, a people yet more barbarous and unknown, who established themselves in all parts of the globe then under Saracenic dominion, and by their brutal despotism degraded the Arabians to a condition approaching that from which they had emerged. This secms to have been ever the result of Turkish conquest.

Meanwhile the Greek nation, which was for so many ages at the head of civilization, gradually lost its power, virtue, courage, glory, and independence, and continned to descend, until now it exercises no influence whaterer on the course of events. During the course of the Arabic Period only one Grecian physician merits mention on account of his writings, and in these there was nothing new except what he had borrowed without credit from the Saracens.

The Empire of the West,- that is, the western part of the ancient Roman Empire,-after subjugation by barbarians from Germany and Scandinavia, fell under a cloud whose darkness overwhelmed it. Its people, however, gradually received new life by commingling their blood with that of the invaders. Later they were able to repulse 
the Salracens who poured in wpon them from Spain; then they turned their armies aganinst cach other, and wrought mutual haroc and ron for sereral centuries, Again, roused by roligions fanaticism, as had been the Mohammedans previousty, they rushed by thousands upon the plains of Asia Minor, syria, and ligyt, which had been for centuries occupied by the Alabs; and their adventures and enterprises, and the new and varied scenes through which they passed, gave rise among the "Francs" to some taste for poetry and works of imagination During the twelfth and thirteenth centuries govermments became more stable, liberil institutions were created, the rust of ignorance gradually disappeared, and by the end of the Arabic Period there were really apprent brilliant streaks of mentality in the horizon of the nations of Europe. In this progressive morement the study of medicine shared. In the thirteenth century it was worthily represented in Italy, in Paris, and became established in Montpellier. Notwitlıstanding, up to this time physicians apparently only knew how to timidly follow in the track of the drabians, and approached little, or not at all, in their studies, the purer lore of the Greeks.

TIIE AGF OF RENOVATION.

This Age of Renovation (extending from the commencement of the fiftenth century to the present time, according to Renouard's classification) is divided into the Erndite Period, comprising the fifteenth and sixteenth renturies, and the Reform Period, comprising the seventeenth and eighteenth centuries, and one should add, in finct, the nineteenth. In general literature this age is known as that of the Renaissance, and is one of whose hegiming a great deal has been written, and so much better than I can put it in this brief work, that to general sources I should perhaps refer those who are interested in knowing how and why there came about such 
a tremendous change in methods and habits of thought and in acquirement of knowledge. But it is the history of medicine that at this time we particularly desire, and our minds must be, in some slight degree, prepared for the great changes to be reconnted by some, with the conditions which brought about this revolution. It was truly an awaliening in every department of knowledge and along every line of study; it was as if the minds of men had been dormant and lost their power of receptivity, and, after a long period of torpor, awakened in a new atmosphere amid new surroundings; as if there had burst upon them a sudden appreciation of ability to do things hitherto undreamed of, and to acquire knowledge such as hitherto had been possessed by none. Once free from the shackles imposed by anthority of the past, these minds severed their Gothic bonds, and stanted forth in every direction with the ardor of youth and the interest of novelty, all engaging in the general enterprise of erecting from the débris of antique science a new temple to the mind in which to worship. While some delved among the records of the past, others songht to bind the past and present, and others, bolder yet, cut entirely loose from it, rejected all tradition, and would fain have built this temple with entirely new materials.

Now, what led to this sudden awaliening? Was it chance, or the effect of certain canses which had long been operating? It has been seen that hospitals and various institutions, whose foundations were dedicated to liumanity, were erected in all parts of Emrope; that gradually there had come about a better social organization; that there had been a diminution of conflicts between princes and their rassals, and the relations between the two were more nearly at an equilibrinm. Moreover, the invention of the compass, which rendered long royages less dangerous and more frequent, opened up to trade regions hitherto inaccessible or unknown, and attracted interest toward commerce as a means of pecuniary gain. The telescope had been invented, 
and astronomy was able to seize mpon some of the facts by it reveided, and therely to make more interesting calculations concenning the motions of celestial bodies, and attain a knowledge of our solar system and its laws. Giadually the microseope shed light upon the hitherto unscen; eneraring on copper labd added its power of illustration to the works of the great writers as they appeared; but above all. that which bronght about this comdition of affairs was the discorery of the aut of printing. 'The first attempts in this direction were made between the years 1435 and $1+40$. and by the mited efforts of three men, whose names deserve mention so long as their art exists,namely, Guttenberg, Fanst, and Schoeffer. 'Thanks to them the same information conld be multiplied in manifold form and tramsmitted to all parts of the civilized globe. In this wa! intellinence and reason become trimmphant; thenceforward the dominion of brute force was broken, and knowledere, because capable of dissemination, became imperishablo.

It the commencement of the Erudite Period Arabic literature still predominated in medicine. Rlazes, HalyAlbas, and dricemua were miversally involied and explaned. But a taste for Greek literature began to prevail in the murersities of Italy, and was finally extended to every part of Enrope, expecially after the taking of Constantinople by Mahomet II, Emperor of the 'Turlis, in 14.53. 'This disaster, which at first bade farr to be a mortal blow to Cireek literature and language, strange to say, served only to hasten their resurection in the Occident. Constantinople having been given orer to pillage at this time, most of its lamed men escaped, carrying with them all manu-cripts that could be seized; most of these found refuge in Italy, and enlightened protectors in the allpowertinl prince of the house of Medici, in Florence, in the popes at lame. and in Alphonso, of Araggon, King of Naples and sicily. Everywhere these fugitives spread the 
knowledge of the masterpieces of Greck literature and art, and in this way a taste for books, libraries, and somnd erudition was diffused, while the Grek and hatin classics were hunted up and published with great patience and ardor; thus the works of the old writers were edited, translated, commented npon, and everywhere disseminated throughout Europe.

Anong those who deroted themselves to the thankless task of editing, and purifying from interpolations, the works of the classic writers was Nicholas leonicenus, born near Vincenza in the year 1428 , who studied medicine at Padua and taught it for more than sixty years at Ferrara. He possessed great vigor of mind, with purity of manners and serenity of sonl, and was the first to translate directly from Greek into Latin the aphorisms of Hip)pocrates and portions of the writings of Galen. He combated in every way the infatuation of his contemporaries for the Arabians and their lore, and called attention to many of the eirors of men who, like Pliny the naturalist, had fallen for lack of fully understanding the Greek anthors they compiled. At the ripe age of ninety-six he died, regretted by all.

'Thomas Linacre, of Cunterbury, a contemporary of Leonicenus, though younger (1461-1524), studied first at the University of Oxford, went to Italy in 1484 , and in Florence attracted the attention of Lorenzo de Medici, who made him the companion of his own children, to whom he gare the best possible advantages. In due time he returned to England, where his talents speedily won him high station, and he became physician to King Henry TIII, and later to Queen Mary. Linacre was the first Englishman, it is said, who spoke purely the language of the Romans. He translated several books of Galen that are still esteemed; and caused the founding of two chairs. one at Oxford, the other at Cambridge. whose incumbents were charged with the duty of explaining the works of Hippoc- 
rates and Gilen. But he is most entitled to the gratitude of his countrymen for his influence in founding the College of london. 'To appreciate properly its importance and his merits, we must remember the obstacles that had to be surmounted; for at that time bishops alone had the right to accord, in their own dioceses, permission to practice medicine, and, consequently, the healing art was abandoned entirely to mouks and illiterate empiries. It was well that limare luad inthence at court, else le conld never have obtaned the reform of such overwhelming abuses; but he triumplied in spite of powerful opposition, and secured the issue of letters patent which prolubited the practice of medicine by any one who had not received a degree in one of the two universities in the kingdom, and been examined by the President of the Collerge of I ondon assisted by thee others. This was the achievement which gave this learned man the title of " Restorer" of Medicine" in Fungland.

Leonicems and Linacre, who were of the early Ermdite Period, also merit mention not merely because of literary talents, but because they were the first eminent physicians to embrace the study of Greek classics, and to proparate the knowledge therein contained. Subsequently others followed the same course, - too many, in fuct, to be enumerated; but it was easy to follow after such leaders. from the time when men began to realize the superiority of Greek models orer prolix Arabian commentaries, they were anxions to seek the light at its source, and applied themselves with avidity to the study of the originals. At this time copres of Greek authors were few in number anc? in a deplonable condition, owing to neglect. To rediscover them, to purify. to eliminate what was not original, to rearange, and finally to multiply by the aid of the printingpress was an extended labor requiring great knowledge, rare sagacity, and commendable patience. One of the greatest publications in medical literature belonging to this epocil was a complete edition of the Iippocratic writings, 
translated into Latin by Annce Foes,-a poor, but learned, practitioner, who lived on the products of his business as pension physician in the eity of Met\%, - and issned fiom Frankfort-on-the-Main in 1495. 'To this master-work Foes consecrated forty years of his life. Another treatise belonging to this same time, less important, perhaps, from a medical point of view, but nevertheless showing great erudition, was a treatise on the gymnastics of the ancients, by Jerome Mercurialis, a work said to be not less precions to historians than antiquarians. It was by such intense zeal and hard labor that true erudition was restored in Europe.

Following now some of the special branches of mediral learning and their development, let us look first at anatony and physiology. I have already related the salient points of the life and labors of Mondino, of whom it is said that, about the year 1315 , while professor at Bologna, he dissected the bodies of two women, and shortly after pulslished an epitome of anatomy illustrated with wood-cuts. Also has been montioned the prohibition of matomical study pronounced by Pope Boniface VIII, in 1300. It was only toward the close of the fifteenth and the early years of the sixteenth century that this prejudice began to abate; the popes, who then stood at the head of scientific movements, withdrew their interdictions, and the universities of Italy gave public dissections. Achillini, Benedetti, and Jacques Berenger dissected at Bologna, Padua, and Pavia, previous to the year 1500 ; soon afterward their example was generally followed.

Jacques Dubois, whose name was Latinized into Jacobus Sylvius, was born in 1478, in a village near Amiens; he studied in Paris, where le worked most industriously at anatomy, which later he was so successful in teaching. He was the first to arrange all the muscles of the human body, to determine their functions, and to give names to those of them which had not yet been so designated. He 
discovered the valves of the lange veins, and was the first to study the blood-ressels by means of colored injections. Ine gave the same careful attention to pharmacy, and in Paris. before a large class of students, began lectures on anatomy, physiology, hygiene, pathology, and therapentics; these he continned until the faculty, on account of jealousy, intermpted them. IIe then, in 1529, went to Montpellier, but retumed two vears later to become a member of the ficulty, and once more lectured with the greatest eclat. later yet he became a successor to Vidius in the Royal College,-a position he retained up to his death in 1555 . His medical writings were extensive and marked by great accuracy, while for anatomy he did a great deal, contributing much to popularize it. He dissected a great number of animals and as many human cadavers as he cond procure, the number, however, being small. Unfortunately, he subordinated all his own research to the authority of Galon. being himself among those anatomists who permitted themselves to be so far misled.

The man of genius and courage, who accepted the truth of what his eres revealed to him, and who was the true reformer in anlomy, was Andreas Vesalius, born at Brussels, in 1514, of a fiumily already illustrious in medicine. He studied at the University of Lonvain, where he early revealed the inclinations of the anatomist, since in his leisure moments he was wont to amuse himself in dissecting small animals. Near Louvain was a place where criminals were executed; and Vesalius, having observed the body of one from which the soft parts had all been cleaned away by ravenous birds, only the bones and ligaments remaining, detached the extremities separately, and then carried off the trunk by night, thus possessing himself of lis first slieleton. Attracted by the fame of Sylvius, he afterward went to Paris to become his pupil, but, not content with the lessons of his master, continued to observe for limself. On the hill Montfunçon, where 
executions took place, he disputed with dows and rultures for the remains of eriminals, or by stealth disinterred bodies from the cemeteries at the greatest persomal rikk. So great was his application that his progress lecame rapid, and at the age of twenty he gave instruction to fellow-students; at twenty-two le became Professol of Anatomy at Padua, being appointed by the Senate of Venice; at twenty-nine he issmed his great work on anat.

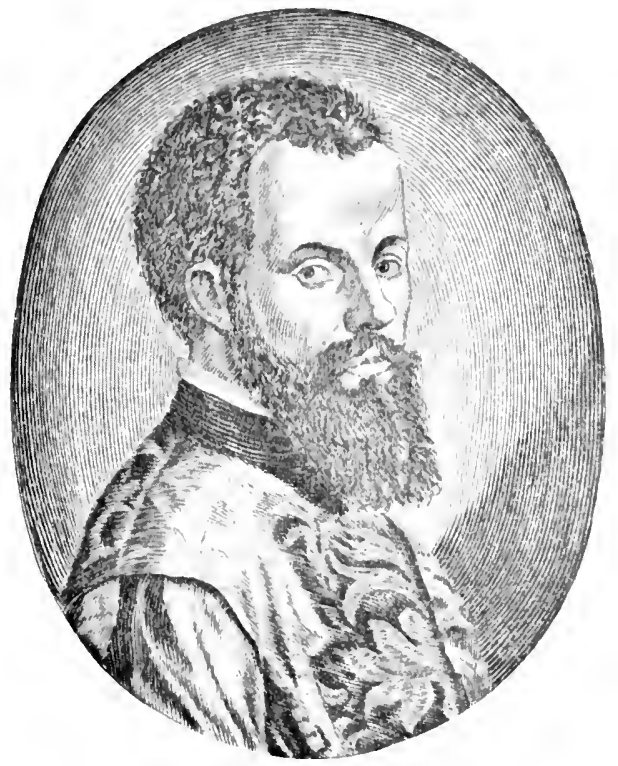

Fig. 7.-Andreas Vesalius.

(From an olt etching by Esme de Boulonois.)

omy, which showed a completeness that left far in the rear all that had hitherto been published on this subject. 'The following year he was called by the Emperor Charles $T$ to the court of Madrid, then the most brilliant in Europe. where he became the first physician, and from this time abandoned his anatomical labors.

He was the first who dared to dispute the words of Galen and point out his errors, - to ascertain that the 


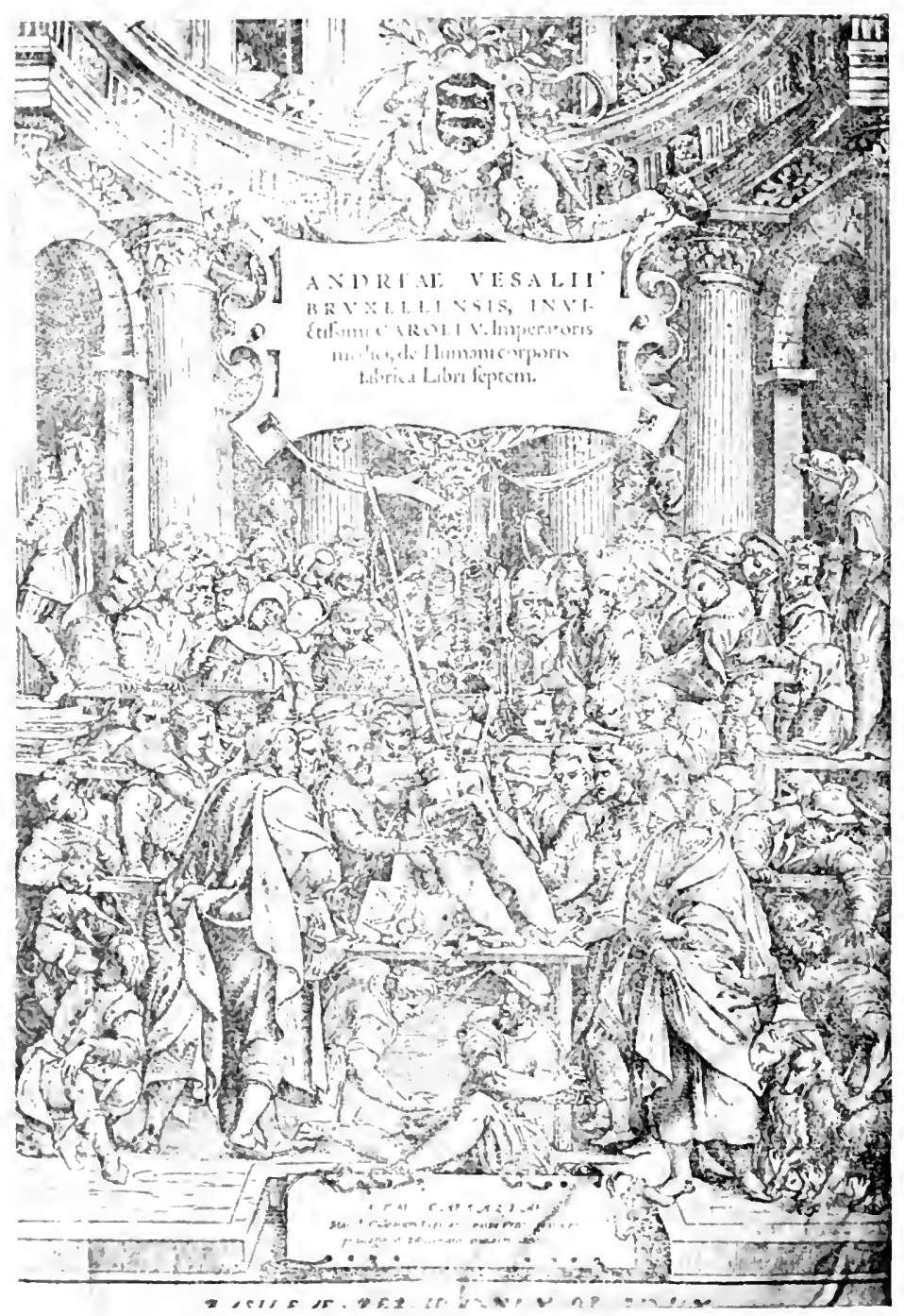

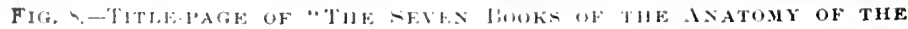

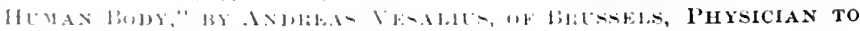

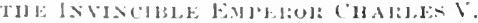


greater part of Galen's deseriptions, having been made from monkeys, did not correctly represent human anatomy. This audacity raised a crowd of vehement opponents, the least reasonable and most finlatic being his old master, Sylvius; but even these onslaughts conld not conceal the truth. The minds of men generally were ripe for the revohution whose signal-fire was thus lighted, and 110 sooner did Vesalius appeal from the decision of Gaten to observation of nature than a crowd of anatomists were reaty to follow his method. He died in 1564 .

One who, at Padua, had been first his pupil, then his co-laborer,-namely, Columbus, born at Cremona in 1490), - succeeded him. Columbus criticised, in some respects, the statements of his eminent predecessor, which he conld better do, since he is said to have lissected fourteen bodies every year, as well as to have practiced renesection. He came so near to discovering the mystery of the circulation that it is strange how he conld have missed it. He even appreciated the systole and diastole of the heart and the connection thereof with dilatation and contraction of the arteries. He knew, also, that the pulmonary veins conducted arterial blood, and that the pericarlinm was a shut sac. He even appreciated the lesser circulation, since he described how the blood left the right side of the heart and passed into the lungs, and came back through the veins into the left ventricle; because of this discovery, and in spite of his utter failure to appreciate the greater circulation, he has been by some regarded as entitled to the credit which is universally given to Harrey. From his position as teacher in Padua Columbus was called to Pisa, and from Pisa to Rome, where he died in 1559.

Another of the great anatomists of this period, second only in fame to Vesalins, was Eustachins, born about the beginning of the sixteenth century. He became physicim to the Duke of Urbino, and in Rome a city physician and professor of anatomy, continuing to tcach in the latter city 

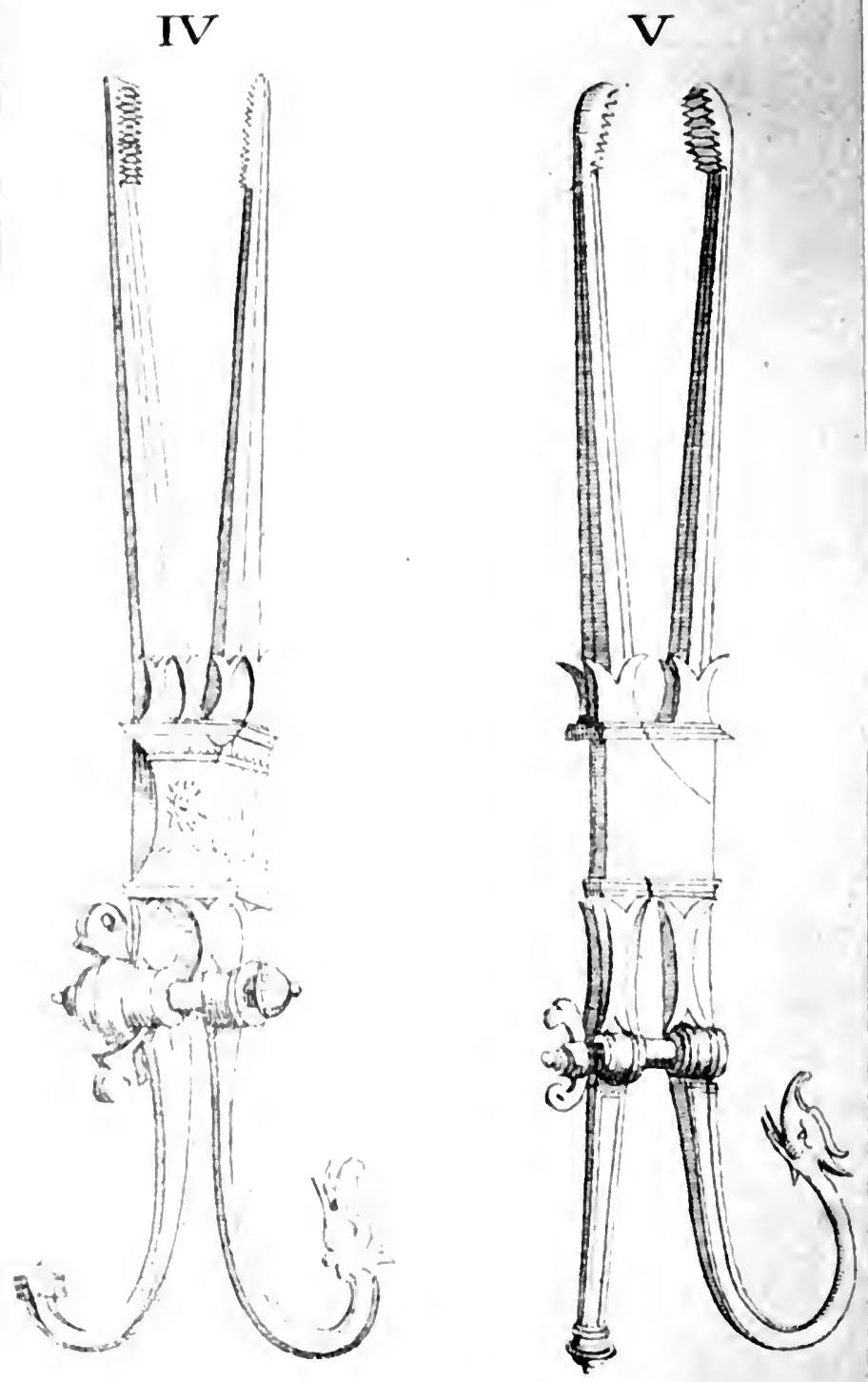

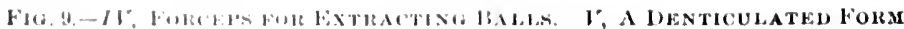
of Fureles. 
until overtaken by his final sickness. He was a definder of Galen rather than an opponent, and somght to shelter his reputation from the attacks of Vesalins. In his pratise it must be said that, for his day, he was a great anatomisl; his ehief discoveries were in the domain of companative anatomy. He brought to bear upon his work a linowledge of embryology which enabled him, for instance, to describe the kidueys and the teeth much more accurately than wontd otherwise lave been possible; he noted, also the pathological changes in bodies dissected, and is brought daily to om minds as we think of the connecting channel betwcen the pharynx and the middle ear, to which his name has been given. He died in 1574.

Fallopius, born in Modena, in 1523, was professor successively at Ferrara, Pisa, and Padua. He cultivated anatomy with the greatest ardor, and, in consequence, his name is also linked with that of Vesalius, as are those of

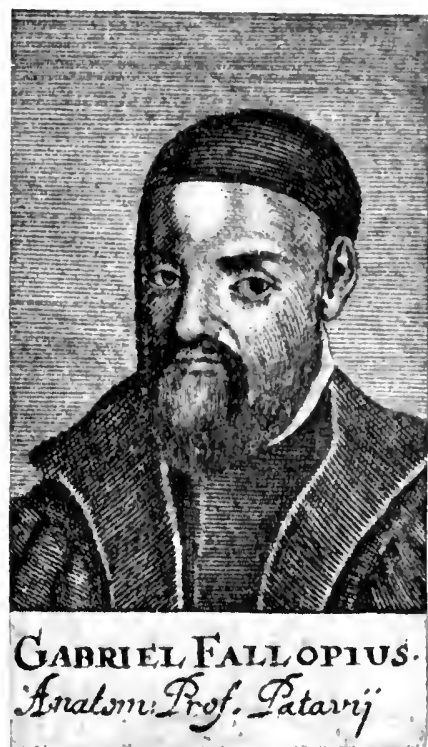

Fig. 10. - Fabrite Fatilotios.

(From an old otching of the sixteenth century.)

Herophilus and Erasistratus in the history of ancient anatomy. Itis anatomical researches included all parts of the human body, and his name has been given to the tube through which the ovum enters the carity of the uterus. Death overtook him in the year 1562.

Jerome Fabricius, better known as Fubricius ab Aquapendente, was bom in the town of the latter name, near the sonthern end of the Apennines, in 1537, receired his 
early education in Palua, and studied anatomy under Fallopius, whose assistint he also was. After the death of the latter he succeeded to the professorship of anatomy, and later built, at his own expense, a large anatomical theater, in which he lectured and demonstrated to students from all parts of the world. 'Toward the end of his life he had accumulated a large number of specimens, and published extensively on anatomy, embryology, physiology, and surgery. Thengh often accredited with discovering the valves of the veins, he is not entitled to that honor, since Erasistratus, Sylvius, Vesalius, and others had previonsly described them, Estiemes had seen them in the azygos veins, and Canano in other veins. His true claim to glory rests upon embryological researches, which he was the first to undertake in a comparative way. In $D e$ Formato Fotu he elucidated the development of the embryo and its membranes by a long list of observations on lower animals of many species. He was probably the first to describe the uterine decidua. Fabricius died in 1619 .

This Fabricins must not be confused with the almostas-renowned Fabricins Hildanus, who was born in Hilden, near Dusseldorf, in 1560. Under the German name of Wilhelm Fibry he became widely known as a surgeon, and, after traveling through France, settled in Hilden, but later moved to Cologne, where he founded an academy. Ilis first treatise-on gangrene and sphacelus-quickly male him known, and went through eleven editions. From Cologne he went successively to Genf, Lansame, and Polen; retumed to Cologne; and finally. after several other visits, settled in Bern, where he died of gout and asthma (in 16:34). II is frequent changes of location were, perhaps, less the result of instability than a testimony to his reputation, inasmuch as he was invited from one place to another. He has been, with propriety, named the "German laré," since he rendered such great service to German 
surgery, and was not only an expert therein, but likewise a cultivated physician and polished humanitarian; in fact he was ahead of his time, by many years, in these regards, as is shown by his recommending amputation in cases of gangrene, and his writings concerning gunshot wounds. He enjoỵed a ripe experience also in obstetrics, and even instructed his wife in the obstetric art and praised her ability most highly. His most important contributions to literature were in the field of surgery, and these passed through numerous elitions, while his opinions and practice are quoted eren to-day.

During this epoch many modifications were introduced and improvements made in the teaching of medicine. Permanent amplitheaters were

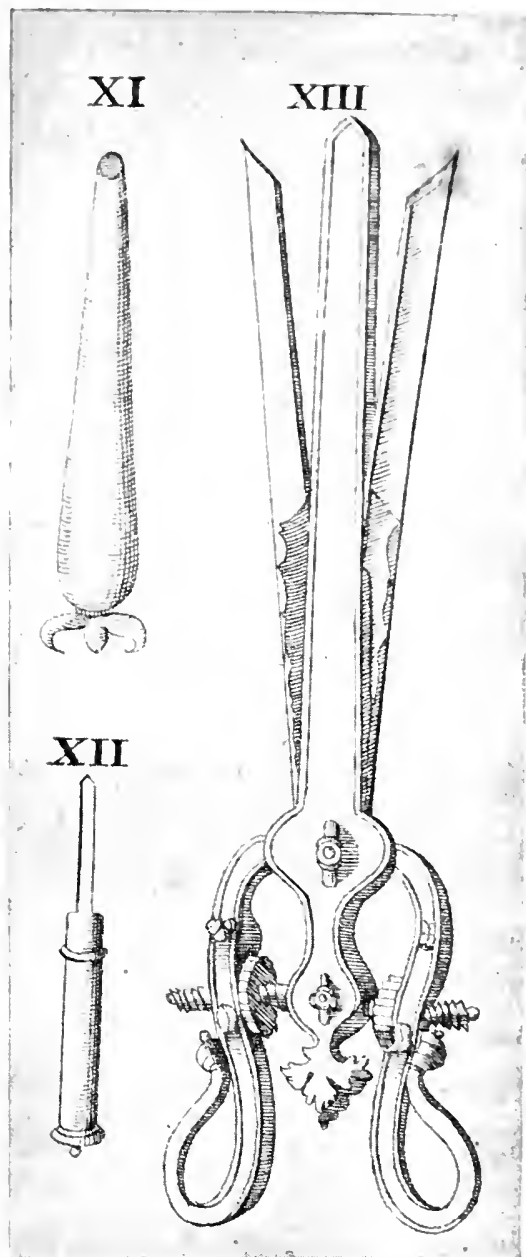

Fig. 11.-Foris of Forcers for ExLatgixg lousis.

(From Opere Omnin Ametomice ef Chirurgica, is Andreas Vesalins, Ià6s.) established for dissection, and chairs of anatomy created. their incumbents being paid ont of the public treasury. The popes appear to lave taken the initiative in this 
respect, which accounts for the great number of subjects with which Eustachins was supplied, as compared with Vesalius, who obtained only two or three in a ycar. Up to this time the razor lad been the sole instrument of clissection, hut was now replaced by the scalpel, which remains in use to-day. By the labors of the few men mentioned anatomy acquired a degree of perfection which it had never attained under the Greeks. Skillful artists put their labors upon paper, and plites and descriptions made from anatomical preparations represented the various parts of the human body with more fillelity than had been supposed possible. Nerves, tendons, and ligaments were no longer confused, but traced so far as possible from origin to ramifications. Ancient errors grencrally were corrected. It was proven that there was no bony structure in the tissue of the heart, that the partition between its cavities was not porous; and attentive examination of its ralves led to the discorery of the lesser circulation by Columbus. Michael Servetus, whom John Calvin burned at the stake, was perhaps the first to note this phenomenon. He saw that the blood could not penetrate directly from the right into the left carity of the heart, but that it was necessary for the whole fluid to pass through the hurgs, where it became impregnated with the vital spririt of the atmosphere, and reached afterward the loft anricle; the position of the valves in the pulmonary arteries and reins clearly confirmed his conjecture. Moreover the size of the pulmonary arteries was enormous, and disproportionate to the quantity of blood necessary for the nutrition of the lungs, which seemed to prove that this was not, as had been believed, the sole purpose of those resels. It was about this time that Fabricius ab Aquapendonte pointed out valres in veins in various parts of the body, and that Columbus and Andreas Cesalpinus explaned more fully the mechanism of the lesser circulation; in fact, the former so closely approached an appreciation 
of the purpose of the vascular system that some lave thought he really knew it, but the passages in his writings thought to sustain this opinion are not at all conchusive. He seems to have confused the action of the heart during sleep with that during the waking hours; and although he realized that the blood could not flow backward through the arteries, that the vena cara was the only ressel which permitted the entrance of blood into the heart, and though he spoke of anastomosis between arteries and veins and remarked that if a band be applied around a limb the veins swell below the ligature, he contented himself with comparing the motion of the blood with the flux and reflux of Euripus, as Aristotle had done. It is even thus that he tortured his mind in trying to reconcile two irreconcilable theories,-i.e., the opinion of the ancients on the motion of the blood and recent discoveries in the anatomy of the vascular system. 


\section{CIIAPTER V.}

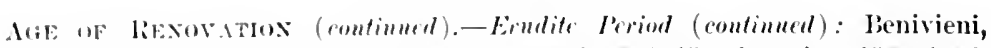

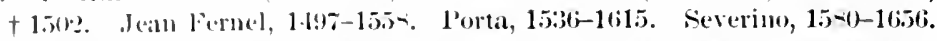
lncolperation of lirotherherel of st. Cône into the Lniversity of l'aris, 1515.

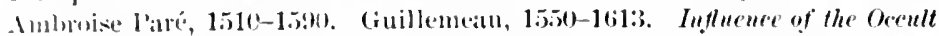

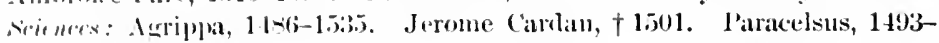
1511. Lotal, born 1531). Jouluert, 15:3!)-15-3.

Is the domain of pathology the Arabs had added only at very small number of observations to those contained in the works of Galcn. 'The most interesting of these pertain to emptive fevers. Most of their writers contented themselves with malinge an inventory of the acquisitions of the pant, as did Giny de Clianliac, and this was about all they conld do under existing circumstances; althongh they did not make discoveries, they prepared the way for their successors.

'Two men about this time did a great deal in the direction of creating a desire for post-mortem study of cases, and in illustrating and succinctly describing symptoms.

The first of these was Benivieni, a Florentine, who died in 1502-the date of his birth being uncertain. 'T'o him, more thin to any other, we owe the commencement of the study of gross pathology and pathological anatomy. He was the first to consider the knowledge that might be obtained by opening bodies for the sole purpose of ascertaining the location and cause of the diseases from which they had died. As Malgaigne remarks: "A eulogy which he merits, and which he shared with no other person, and which has not been accorded to him up to this time by the many historians of surgery who have superficially searched among thene precions sonres, is that he was the first who hard the habit, folt the need, and set the useful example, which he transmitted to his successors, of searching in the ciular ver. arenuling to the title of his book, for the concealed callses of dircane." The work referred to by Malgaigne (114) 
was entitled: Concerning Some of the Servet and Stronge Cunses of Disease and was published in V'lorence in 1507. It is poor in quotations, but rich in original obscriations, which pertain especially to the etiology of disease, and gives a very concise symptomatology and history of each affection of which it treats, as well as a pathological explanation. Benivieni's olservations on gall-stone, on the anatomical lesions of heart diseases, and on the conveyance of syphilis from the mother to the foetus were original, as well as many observations concerning the presence of worms and other parasites in the body.

He did not limit himself to dissection of his own cases, but sought autopsies in the cases of others. He examined the bodies of those who had been hung, always thinking to find in them something of interest. In this regard lie was followed by one already mentioned,-namely, Eustachius.

After these two the men who most cultivated pathology and anatomy in the sixteenth century were liembert Dodoens and Marcellus Donatus. 'The former' was born in 1517, in Mecheln, traveled extensively, was plysician to Maximilian II and the Emperor Rudolph, and died in 1585. The latter lived and worked in the latter half of the sixteenth century, the dates of his birth and death being somewhat uncertain.

The next man whom we must mention is one who did a great deal for internal medicine, pathology, and anatomy. Jean Fernel, who lias been surnamed "the modern Galen," was born in Clermont in 149\%. Even as a boy he showed great aptitude, and rery early made himself a reputation in philosophy, law, and mathematics. In 1530 he was received as doctor, with the nuanimous applause of the entire ficulty of Paris. He secms to have been stimulated by this only to more extended study; in fact, so hard did he work at his studies that his friends became seriously alarmed for his health. and remonstrated with him; they receired for reply: "Destin!" 
reserces for us repose enough." He became physician to King llenry II, of France, and in the midst of a very extensive practice undertook to collect all the medical knowledge scattered in the Greek, Arabic, and Latin works, in orler to form from it a body of doctrines. llis work was written with a purity and elegance of Littin that reminds one of Cicero. 'Throughout its pages he was philosophic, and sought to unite the apparently irreconcilable doctrines of Plato and Aristotle.

Ite livided medical science into three great sections, physiology, pathology. and therapeutics. In his explanations of discase he was too often fanciful, following the speculations mainly of Galen, and making free use of the hypotheses of humors, temperaments, vital spirits, etc.; but the following statement of his would do credit to a trined pathologist of to-day" "As for myself, I shall nerer believe I have profomnd knowledge of any affection if I do not know positively, just as if I conld see it with my eyes, in what part of the human body is the disease, its primitive seat, what suspicion of organic lesions constitute it, whence it proceeded, if it exists idiopathically or by sympathy, or if it be kept up by some exterior cause. He who pretends to be a rational physician must somud each of these subjects, and discern them by certain signs." The problem which he thus set himself he certainly, for his own part, considered as solved, although it was not long before his solutions were set aside and the original uncertainty reappeared.

In therapentics he very early laid down the fundamental maxim that every disease must be combated by contrary remedies, justifying this by every species of argument, amonnting to this: that every disease must be combated by its contrary because all that cures a disease is contrary to it. This was, in part, the doctrine of "Contraria contruris curntur." - the antithesis of the equally absurd sophism: "Similia similibus curentur", which three humdred years later was erected into an excuse for the founda- 


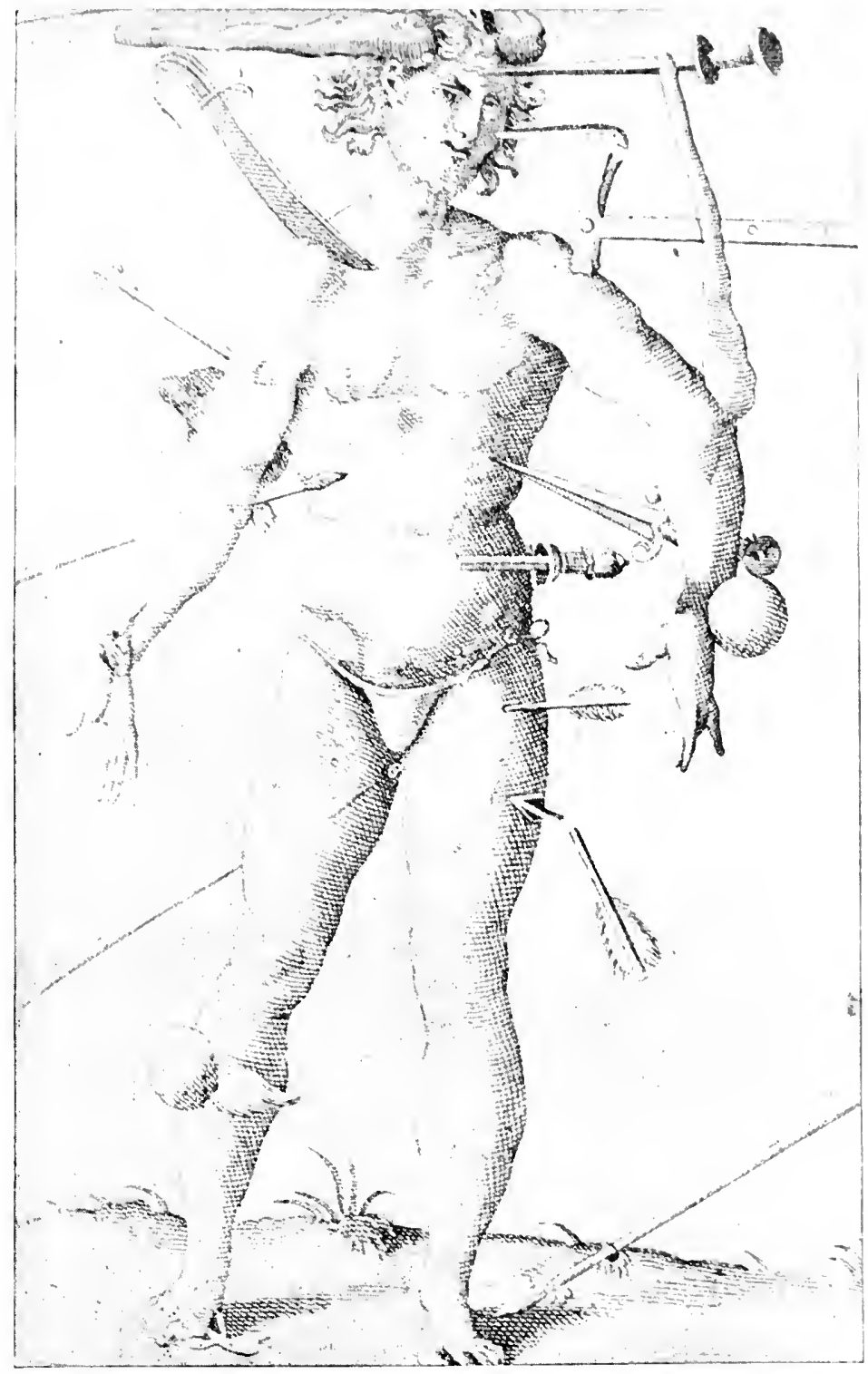

Fig. 12.-Body Showing Various kinds of Wounds.

(From Opera Omnia Anatumica et Chirurgica, by Andreas Vesalius, 15bix) 
tion of an alleged new school. 'There can be no doubt that Fernel rendered rery great service to his time and to subsequent generations, despite the fact that his recommendations and statements were too often founded upon sophistry.

Just here we must digress for a moment to consider the status of bleeding. Hippocrates and Gialen had adrised to bleed largely from the arm on the affected side in plenrisy and pneumonia. 'That practice was gradually abandoned as Greek traditions were lost sight of, and finally the Arabs substituted for it something entirely different,-mamely, pricking a vein in the foot in order to let blood flow drop by drop. 'Their method prevailed throughout Europe until the commencement of the sixteenth century, or about the time when Fernel appeared upon the scene. A Parisian plirsician named Brissot had revived the ancient (the Greek) practice during an epidemic of pleurisy, and had obtained thereby astonishing success, which he hastencel to publish, commending the method employed. He thus created a crreat uproar in the medical world. The innoration found foes and delenders, and disputes grew warm, even to the fever point. Finally, the ancient method was generally revived, and Fernel accepted it.

Felix Plater was born in 1536, in Basel, Switzerland, and died in 1614. He had several sons who made their mark in medicine. In his large work, which preceded that of Fernel, he took perhaps the first step in an unexplored route,-uamely, in the classification of disease according to the totulity of appurent symptoms. Defective as this classification appears in our eyes, its author lived a long life as a very distinguished practitioner and professor in his native town.

Giovanni Batista Porta was born in Naples in 1536, traveled extensirely in Italy, France, and Spain, and founded in 1560 an Academy of the Segreti. He was accused of magic, and was compelled to refute the charges 
in Rome. He died in 1615, having been one of the learling scientists of his time, and the founder of modern optics. In the first edition of his Magia Naturalis, published in Naples, 1587, is fonnd the first description of the cancrat obscura,-of course, in a very incomplete form and without Ienses.

Severino was a celebrated surgeon of Naples. He was born in 1580, in Calabria, studied in Naples, became a doctor in Salernum, and then became professor of anatomy in his native town. For a long time the victim of intrigne and of persecution by the Inquisition, he was finally driven out of Naples, but was called back by the populace. The then became the most celebrated teacher of his time, writing extensively on a variety of subjects. Ife died in 1656 of the plagne, an epidemic of which was at that time langing in central Italy.

Arriving now at the surgery of this Age, we find that matters were more chaotic than in other departments of medicine, and for reasons which are easily given and appreciated. While, ordinarily, external diseases are more easily discerned than internal, and while in a corresponding degree they can be more satisfactorily treated; while, in other words, external pathology has ordinarily taken precedence of internal in professional as in lay minds, this riew seems to have been inverted for a time during the Middle Ages. Previous to the period now under discussion the sciences had generally declined in Europe, and surgery had fallen even lower than medicine, for the reason that medicine was in the hands of the priests, who had at that time something of a liberal education, while the practice of surgery was abandoned to a class of ignorant barbers, bathers, and bone-setters. No mechanic or artisan could take as an apprentice any youth without a certificate affirming his legitimate birth, and that he came from a family in which there were neither barbers, batl-kcepers, shepherds, nor butchers. Among the men who were thus made social 
outcasts were those into whose hands most of the surgery of the fifteenth century fell. 'This was particularly the case in Germany, and other European comntries were little in adrance. We have seen that in France and in Italy lanfranc and Guy de Chanliac did their best to rescue surgrery from the hands of these men, but their efforts did not prevent it from being completely abandoned by the clergy, who deroted themselves to the practice of medicine.

When we come to inquire the reason for this-in other words, why an art so useful as surgery, and one which made such requirements for knowledge, sagacity, and dexterity, whose necessity was almost continually felt, particularly during these troublous times of almost constant warfare, should be so neglected by men who could best comprehend its utility and respond to its requirements-it is difficnlt to find a satisfactory answer. The social condition of the times sheds some light upon the question. 'The nations of southern Europe were socially dirided at that time into the nobility, who were nearly always at war; the clergy, who monopolized leaning and filled the socalled liberal professions; and, finally, the common people, who were common prey for both the other classes, and who ret had to support both without having any privileges of their own. While the practice of medicine was a clerical right, the canon of the church prohibited physicians from drawing blood, under pain of excommunication; and hence surgery, shmued by the priests, to whom it naturally belonged in connection with the practice of medicine, fell into the hands of the ignorant and vulgar, who practiced it in a purely mechanical way, without knowledge or appreciation of its possibilities. In addition to this, there was an almost total lack of detailed and precise anatomical knowledge; and but small reason to expect that the ignorant practitioners of surgery would feel the need of such knowledge. Moreorer, most of the operators were itinerants, going from city to city, stopping so long as they had cases to operate upon 


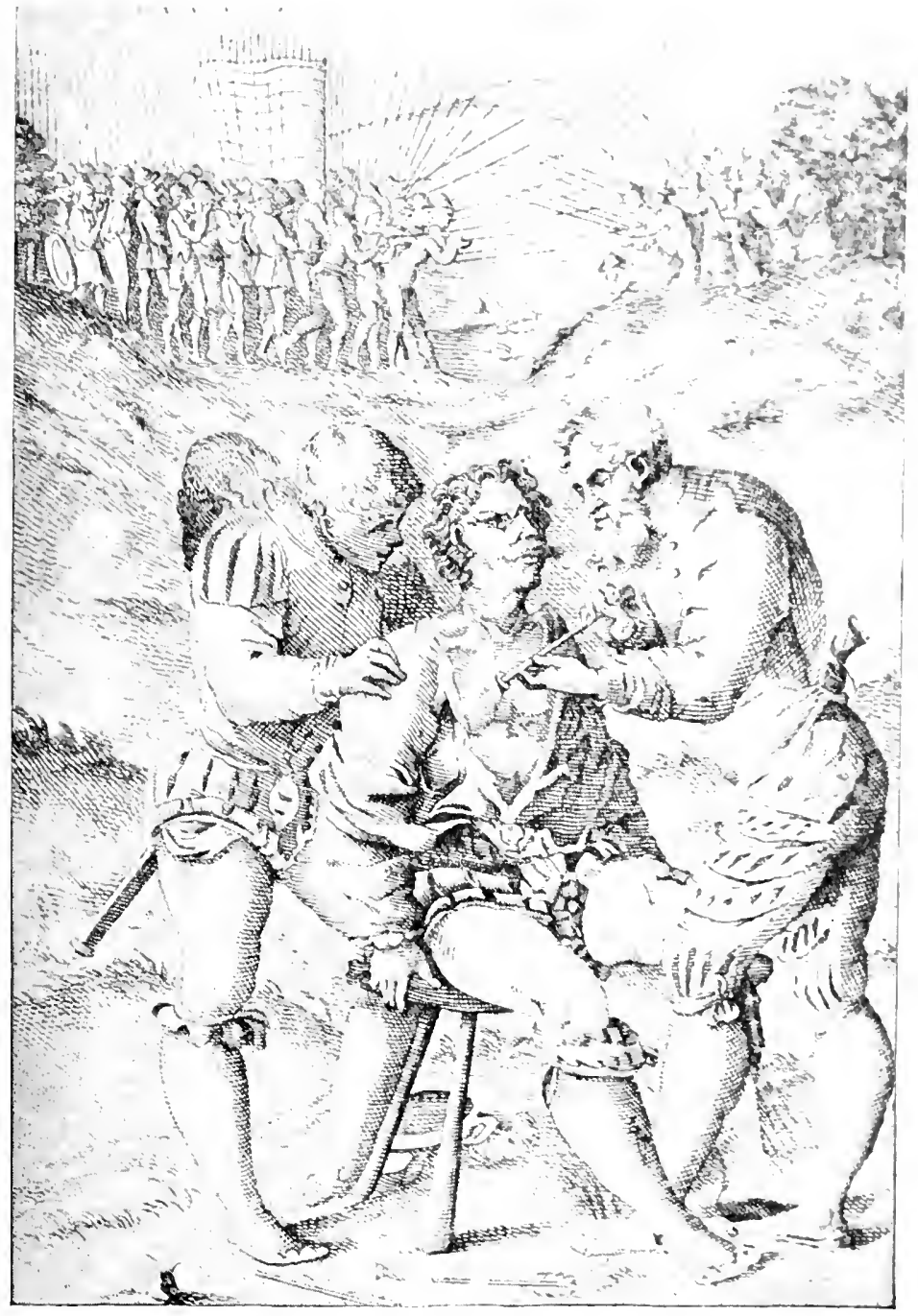

Fig. 13.-Mode of Extracting Leadex Buldets.

(From Opera Omnia Anatemina el Chirworim, by Andreas Vesalius, 1568.) 
or until some reverse forced them to depart. Most of these men limited themaclves to one or two sorts of operations. Some operated for eataliact, others for stone, others for hernia, nearly erery one having a secret method which was transmitted to his posterity as a heritage.

ln the history of medicine certain fannily names of itinerant operators have been preserved; for example, the Branca, the Norsini, in Italy. and the Colot in France.

Under such conditions there could be no such thing as the profession of the surgeon. The prejudice against dissection did not begin to abate until the thirteenth century, when a rery few of the clergy dared, in a very timid manner, to perform surgical operations. 'Their numbers increased in the course of the fourteenth and fifteentl centuries, and in the sixtecnth had become considerable. Most of the great anatomists of that period-such as Benivieni, de C'arpi, Vesalius, Fallopius, and Fabricius ab Aquapendente -were great surgeons.

In due time it came about that while the clerical physicians were willing to descend to the rank of operators, the lay-surgeons aspired to the rank of doctors of medicine. 'This tramsformation took place especially in France, the only country where at that time there was a special college of surceons-the small Brotherhood of St. Côme, already alluded to, which was always contending against the faculty on one hand and against the barber-surgeons on the other, with rarying results, and which, at last, sought peace with the university and was received by it. 'This took place in 15l5, and was the renaissance of surgery, not only for Paris. but for the whole world. By this remion the faculty acquired anthority orer the barbers, who were admitted to their lectures and took courses in anatomy and surgery, cradually attaining a knowledge which entitled them to be called bather-surgeons; their rights were not curtailed, but made more difficult of procurement, for, in addition to passing their initiation for the privilege of becoming barber- 
surgeons, they also had to pass an examination before the plyysicians and the two surgeons of the king, at Chatelet, for the right to practice surgery. 'The surecons, as the price of their submission to the faculty, had, beside the university privilege, a sort of supremacy over the barbers; and thus it happened that the barbers were admitted to the rank of surgeons at St. Côme, and that the surgeons of St. Côme were admitted as barber-surgeons by the ficulty of medicine. In this double capacity they approached nearex the profession of medicine, from which they shonld never have been separated, while surgery became an art which received numerous improrements. We must now derote a little time to the consideration of at least two or three of the men who most contributed to extend and clevate it.

Among those who most contributed to make the period of which we are now speaking a glorious one, raising himself from the lowest walks of life to the attainment of the highest professional honors, is Ambroise Paré, whose name will never die while the art of surgery is taught. Paré was born about the year 1510, at Laval, of poor parents. He was an early apprentice to the provincial barber-surgeons, after which a natural ambition for improvement led him to Paris (about the year 1532), where he studied three years at the Hôtel-1)ien, and obtained the confidence of his teachers to such an extent that he sometimes operated for them. He never learned latin, the language at that time of the boolis and of the schools. Paré was most fond of recalling his hospital experience; he counted it among the highest honors of his life that he should have enjoyed what he there did enjoy, and gives us to suppose that he was a favorite upon whom peculiar favors were conferred. In one of his writings, a physician of Milan having expressed astonishment at so young a man's knowledge, he remarks with pride: "But the good man did not know that I had been house-surgeon for three years at the Hôtel-Dien de Paris." The functions of the barber apprentices in the 
hospital in those days were probably to make dressings and bleedingrs, and sometimes post-mortem examinations ordered by the chices, to assist the latter in their operations, and to act in casc of emergency ; in other words, to do about as the internes at present do. They probably found there a precious and rare opportunity for anatomical dissection, but it does not appear that they had regular clinical instruction.

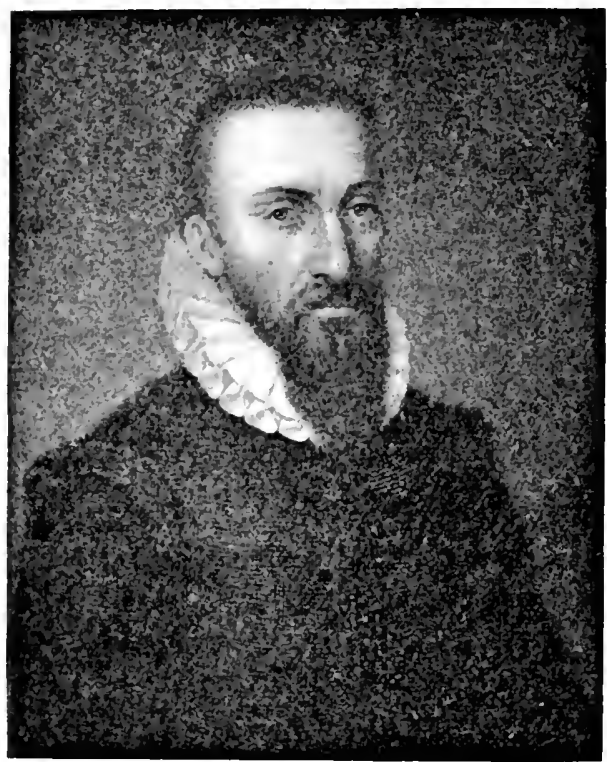

Fig. 11.-AMBroISE PARẼ.

(From a steel engraring of the original painting in l'École de Mledecine at Paris.)

Communication between master and pupil depended absolutely on the pleasure of the former.

In 1537 l'aré was made surgeon to the Colonel-General of Infuntry, René de Montijean, with whom he made his first campaign in Italy. ('This was in the army which King Francis I assembled in Provence with which to repulse the in rasion of (harles V.) He had never seen war nor recent gunshot wounds, and only knew of them by what he had read in the writings of John de Vigo. This 
was at a time when it was the custom of surgeons to poul boiling oil into every amputation or other wound in order to check hemorrhage; and l'arés experience in this, his first campaign, put him in the way of his first discorery, -a discovery which will never be forgotten. Ho has recounted in his Book of Arquebus Wounds and in his great Apolog! how after the affair of Pas-de-suze he watched the other surgeons, dreaming of nothing else but to imitate them as far as he could; how the boiling oil gave out; how his anxiety abont it prevented him from sleeping; and how to his great wonder he found that the wounded who had submitted to the operation suffered more than the others. 'This set him to thinking, and led him, a young man without name or anthority, withont letters or philosophical studies, to observe, to reason, and to combat a doctrine which was miversally admitted and which the highest surgical anthorities of the day sustained. At that time all authors who had spoken of gunshot wounds considered them as poisonous and complicated with bums; consequently they gave the precept to cauterize with boiling oil or a red-hot iron, and at the same time to administer certain alexipharmics which should serve as internal antidotes. John de Vigo, physician to Pope Julius II, assures us that the danger of these wounds results from the round formation of the balls, from heat, and from the poisonous qualities communicated to them by the powder. Mis theory and the method of treatment above given had been adopted withont contradiction until the day when l'alé dared to utter the first protest against them.

After a campaign of three years, in which he lost lis master, he returned to Paris and married. In $15+3$ he was in the army of Perpignan, in the service of de Rohan, grand lord of Brittany, where he gave continuous proof of his sagacity. It was after this campaign that his reputation, so well established among warriors and the nobility, inspired Sylvius with the desire of seeing him. Paré has 
recounted low, in a comversation which they had together, he insisted upon the then entirely new precept,

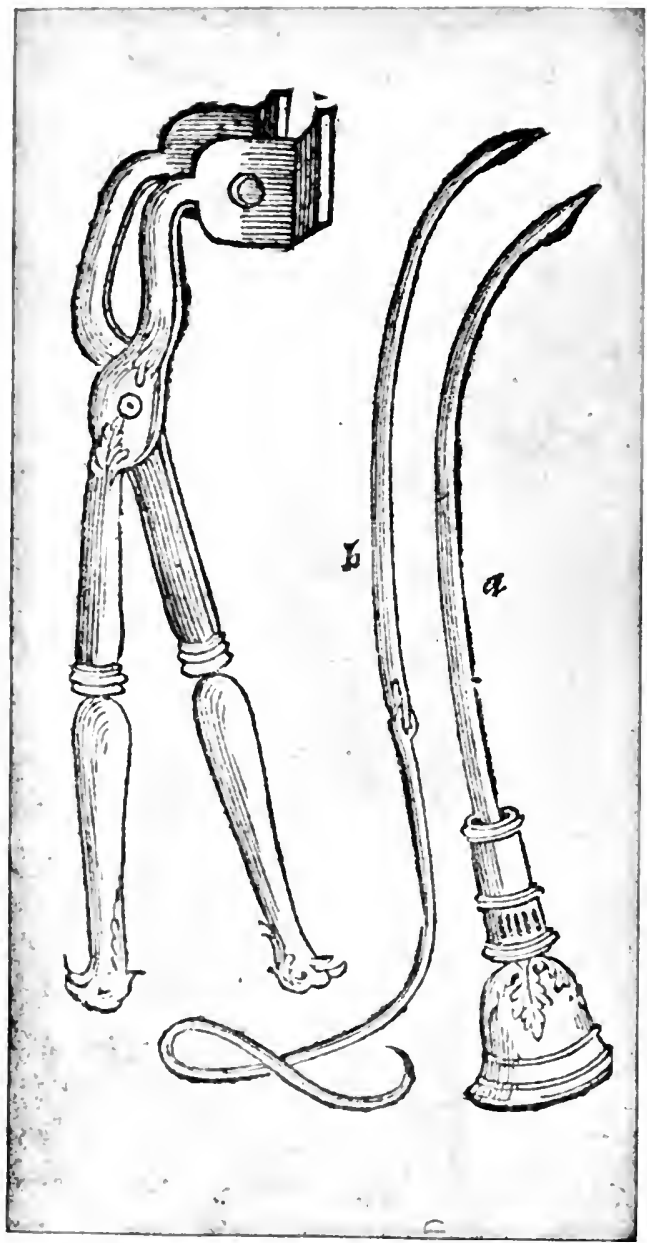

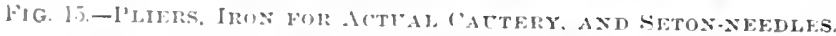

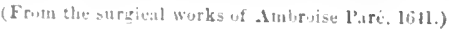

of which he had made many applications, that in order to extrart bullets it was best to place the wounded in the position in which they were at the moment of injury. 
Sylvius, then at the height of his fame, invited the yommgr physician to dimner, and listened to him with great attention while he explained his views on gumshot womnds, which made such an impression "ypon the mind of the host that he besonght him eagerly to write them ont and make them public. Encomraged by this advice from so high a sourere, Paré prepared his text, illustrated it, and in the year 15 t5 brought out his little work, which marked in a manner so glorions the revival of French surgery. It was published by Gaulterot, the sworn bookseller of the University of Paris, and was entitled "The Alenner of Treating Woumds mude by Arquebuses and other Fire-arms, and those made by Arrows, Darts, and the Like; and also by Burns male Especially by Gumporcler. Composed by Ambroise l'uré, Master Barber-Surgeon in Paris."

A few months later appeared the second edition, in which he still recommended the actual cautery in hemorrhage; but each day he meditated upon the subject, and on one occasion discussed it with two surgeons of St. Côme, submitting to them the idea that, since ligatures were applied to veins and arteries, and to recent womds, there was nothing to prevent their being equally applied to amputations. Both agreed with him, and opportunity soon presented itself at the siege of Damvilliers, when a gentleman had his legr erushed by a shot from the fortress. Parré made an amputation, omitting for the first time the use of the cautery, and had the happiness to save his patient, who, full of joy at having escaped the red-hot iron. said he had got elear of his leg on rery good terms. This was, in truth, the actual renaissance of surgery, which had been to that time a torture, but which berame therealter a blessed art. It was a barber-surecon who produced the double marrel. 'This took place in 1552.

In 1554, after other campaigns. l'aré was made, withont examination, Master of the College of 'St. Côme, and in 1559 was included among the surgeons of King IIenry 
II (who was killed in a tommey, in Paris, in 1559), which position he retaned with Francis II and Clarles IX. 'lhe latter raised him to the highest position among his surgeons, and King IIenry III retained him, which callsed the witty and true remarli that the kings of France transferred him to their successors as a legacy of the crown.

Many anecelotes are related of Paré to show the remarkable esteem in which he was held by public and private citizens. For instance, in October, 1552, one of the most eminent generals of Charles $V$ laid seige to the city of Met\%, and the emperor came in person to join the army. Within the walls of this beleagnered city were gathered nearly all the nobility and princes of France. The city was defended by the Dnlie of Guise, and the besieged soldices were at that time suffering alike from the attaclis of the conemy, the results of the siege, and the rigors of a frightful winter. 'The dulie had established two hospitals lor the soldiers, and had put into requisition the barber-surgeons of the city, giving them money with which to furmish their supplies. But these surgeons were sadly incompetent against the combination of unfarorable circumstances, consequently nearly all the wounded perished, and a homible suspicion was roused among the soldiers that they had been poisoned. Under these circumstances the dulie dispatched one of his captains to the king to say that the place could hold out for ten months, and asked at the same time for fresh medicine. The ling sent for l'aré, gare him money, directed him to take all the medicine he thought necessary, and furmished him a letter to Marshal St. Andre, who commanded in Verdum, and who bribed an Italian captain for fifteen hundred crowns to introduce into the besieged city the celebrated surgeon. The expedition was perilous, and Paré himself would have willingly remained in Paris. But he entered Metz on the Sth of December, at midnight, without an accident. IIaving passed already sixteen years in war, 


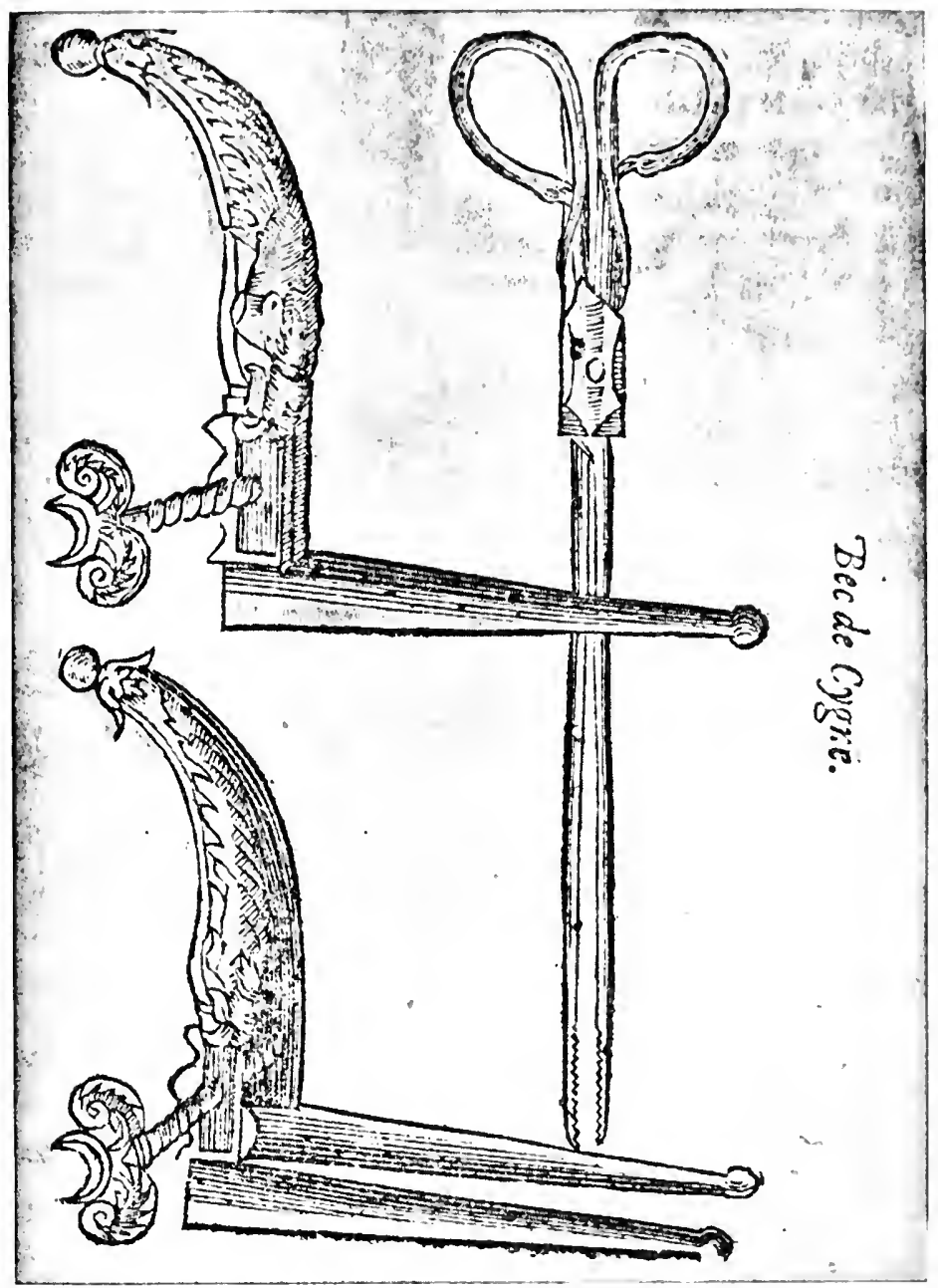

Fig. 16.-SWAN'S BeAK, TSED FOR DILATING TIE TRACK OF A WOUND and Extractixg a Foreign Bowy.

(From the surgical works of Aml,roise Paré, 1611.) 
lie was known to the chiefs and common soldiers. 'The day after his arrival, the duke, who knew how to strike the imagination, presented him on the ramparts to all the princes, lords, and captains, who embraced and received him with clamor. By the soldiers he was received with shouts of trimmph. "We shall not die," they exraimed. "even though wounded; Paré is among us!" From this time the defonse was conducted with renewed rigor, and it has been miversally conceded that to the presence of this single man the city was indebted for its salvation. 'The sicge itself' was not raised until after' a torrific conflict. On the very day of Paré's arrival he began to treat the leg of one of the prominent officers, who for four days had been in charge of a charlatan, and had suffered horrible tortures. The next day he decided to trephine another, who had been struck on the luad by a fragment of stone, and who had been insensible for fourteen days. Both patients recovered.

The little brotherhood of surgeons of St. Côme were ready to seize on every ciremmstance which might redound to their adrantage, and desired to have within their ranks the man who enjoyed such great renown. They, therefore, admitted him to an examination, in spite of the statute which required that the candidate should understand Jatin, and in spite of opposition by the professors of the

DEscmptiox of FIg. 17.-A, the instrument named, on account of its figure, lizarl's beak: in Latin, "rostrum lacerti." It is used to extract balls which have bern flat tened or imbeded in bone. Adisplays partienlarly the cannula. $B$, hinge, ly means of whicll the lizarl's heak is oprened and closed as much or as little as the sureen wishes. $C$, the renl which opens and closes the lizard's beak. When drawn upun it closes aml when pusbed it opens the instrument. $I$, $D$, (lilator and mirror ; in Latin. "dilutatorim, symculum." The instrument is somewhat roughened and dutatel in oriler to take a tim hold of whatever it grasps. It may serve two purboste : first, th bilate and enlarge the wound so that it may be seen to the bottom, aul also to make way for sune instrument, as pincers or erow's beak, and to grasp more "asily and withiraw the foreign hody: secondly, it may itself serve to extract

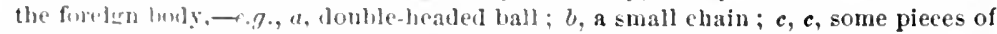
mail. $E, E$, crane's leak: in Iatin, "rostmum gruinum." $I I, H$, duck's beak; in Latin, "rostrum unserinum." $K$, sound. $L$, ball-extractor without cannula. $M$, eanula with hantle. 


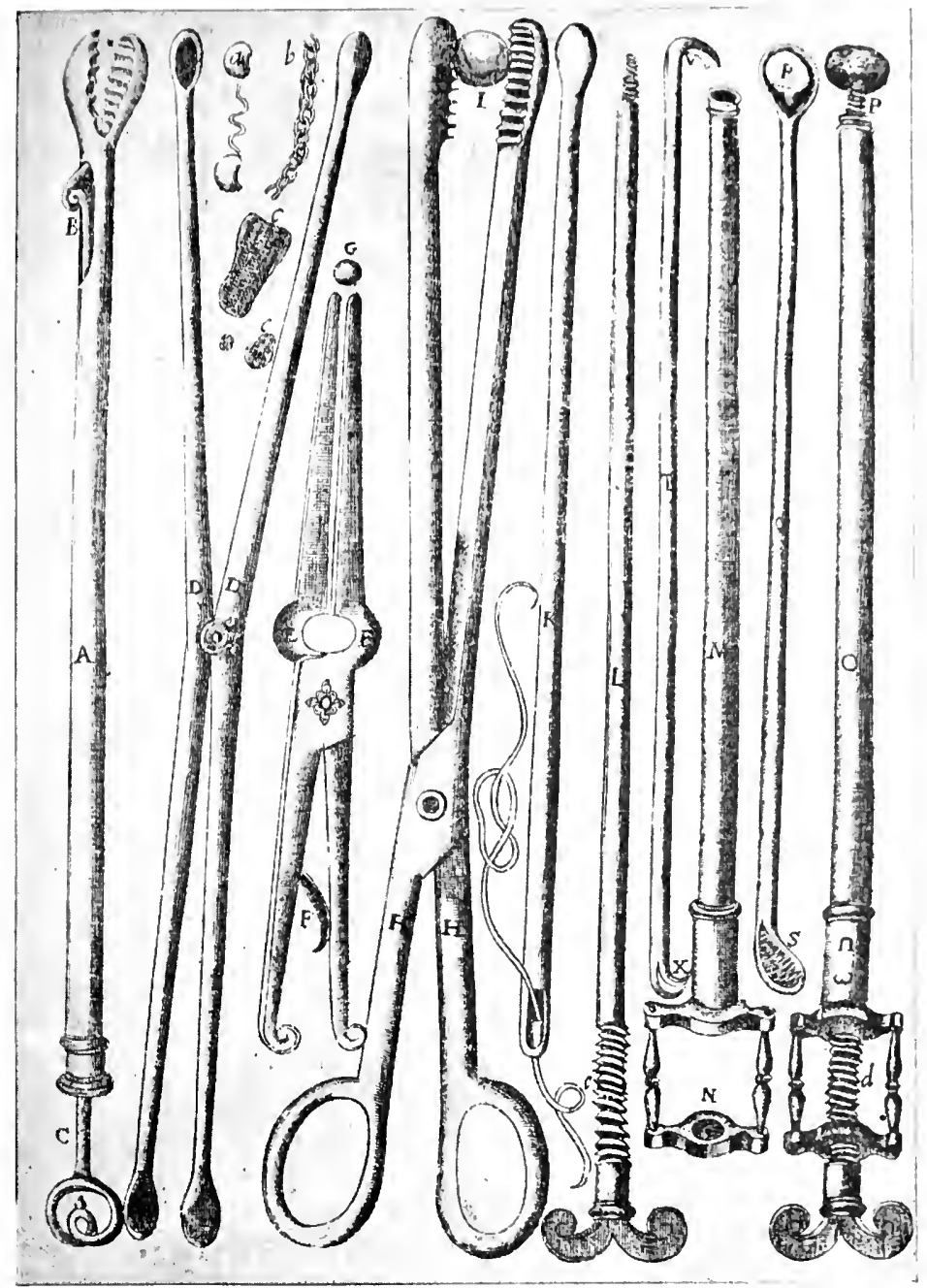

Fig. 17.-Various instrumexts fotr the Extraction of Balls. (From the Works on Chirurgerie, by Jacunes Guillemean, ehirurgeon ordinary to the King of Frauce, lit!.) 
miversity. They not only admitted him to all their dewrees, but awarded him a reception,-a hitherto mknown homor.

laré in his time met with a success which to-day would be pronounced extraordinary. He seemed to inspire the wounded with the utmost confidence, and to possess greatness and firmuess of cliaracter in the highest degree. It is, perhaps, eren more extraordinary that with so strong a character he should have so long retained favor at court. In the midst of the excitement of camps, and a very extended practice, he fomd time to read all that had been published on his art, and to compose himself a great number of works, enriching all branches of surgery. Instead of keeping secret his inventions, as was the custom of the time, he made them as public as possible, saying, in the preface of his large work on surgery: "For my part, I have dispensed liberally to everybody the gilts that God has conferred upon me, and $I$ am none the worse for it; just as the light of a candle will not diminish no matter how many may come to light their torches by it."

Besides his smaller treatises, his large, collective works passed through a number of editions, and were everywhere reprinted and studied. Not only was he great in surgery, but he attained a high degree of expertness in midwifery. Among other things, he restored the forgotten practice of podalic rersion in cases where this procedure is necessary. He died in 1590 .

'The doctrine of Paré on gunshot wounds was rapidly disseminated. From 1550, Magreri, of Bologna, advocated it without giring credit to its real anthor, and sustained it by decisive experiments. He observed that none of the wounded felt any heat. and that the torn portions of their clothing showed no trace of fire; and he shot balls through packinges of powder withont setting them on fire. At the same time lange spread this view in Germany, and Botal, 


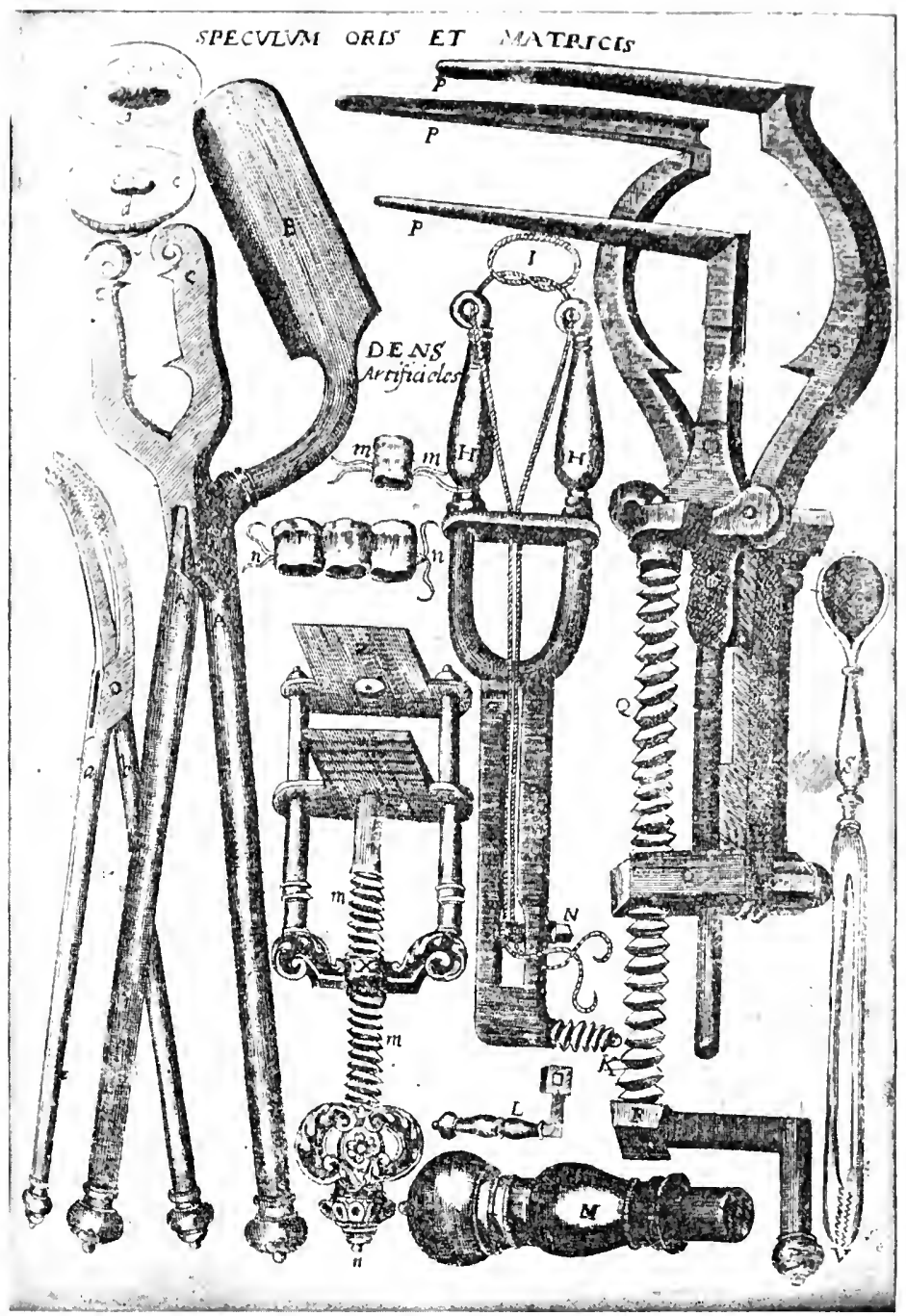

Fig. 18. GPECULUMS FOR TIIE MOUTII AND V'oMB, ETC.

$A, A$, moutl-miror ; in Latin, "speculum oris." $B$, tomerue-1epressor. $C$, $C$, branches to be placed under the chin. $G, G$, instrument for retrenching elongated uvula. $O, O, O$, womb-mirror ; in Latin. "speculum matricis." " $m$, $m$, artitieal tooth of ivory or gold, attiched liy smill wald threads. $n$, $n$, three artificial teetl joined together and attached hy goh threads to the adjacent teeth on each sicle.

(From the Wurks on Chimgeri, hy Jacues Guillemean, chirurgeon ordinary to the King of France, 1619.) 
of 'Turin, took it up (withholding, however, the true anthor's name).

While Ambroise Paré did not disdain to act as acconcheur, it was his friend and pupil, Jacob Guillemeau (1550-1613), who, in the sixteenth century, most occupied himself with the practice of obstetrics. We owe to Guillemean the first improvements that the moderns made in this art; for instance, the proposition to rapidly and artificially terminate parturition in cases of considerable hæmorrhage or when the woman is taken with convulsions during labor. Ginillemcau supported this practice on the anthority of Hippocrates, and operated on a great number of patients, proving its value and the danger of its neglect.

The Cesarean operation was known to the ancient Greeks and Romans, but liad been abandoned during the Middle Ages. It remained for the accoucheurs and surgeons of the sixteenth century to re-establish it. Among others, Rousset, physician to the Duke of Savoy, who recommended it very warmly, reported several cases where it latd a happy issue for both mother and child. He even reported the most remarkable case of all, - that of a woman who was six times delivered by this operation, and who perished in the seventh confinement, because, as he states, the surgeon who had been accustomed to operate on her was absent. Unfortunately, this case is not authenticated.

Nothing shows better how the art of observation and accurate description of phenomena had progressed at the time of the revival of letters than the number of new diseases of which the authors of that period make mention. Then, for the first time did one read of whooping-cough, miliaria, scurry, plica polonica, syphilis, and raphania. It is scarcely credible that these discases fell upon Europe at this particular time. It is more probable that they had a more ancient existence and were not recognized.

Even to-day medical men are divided in their own opinions on the origin of syphilis, some believing that it 


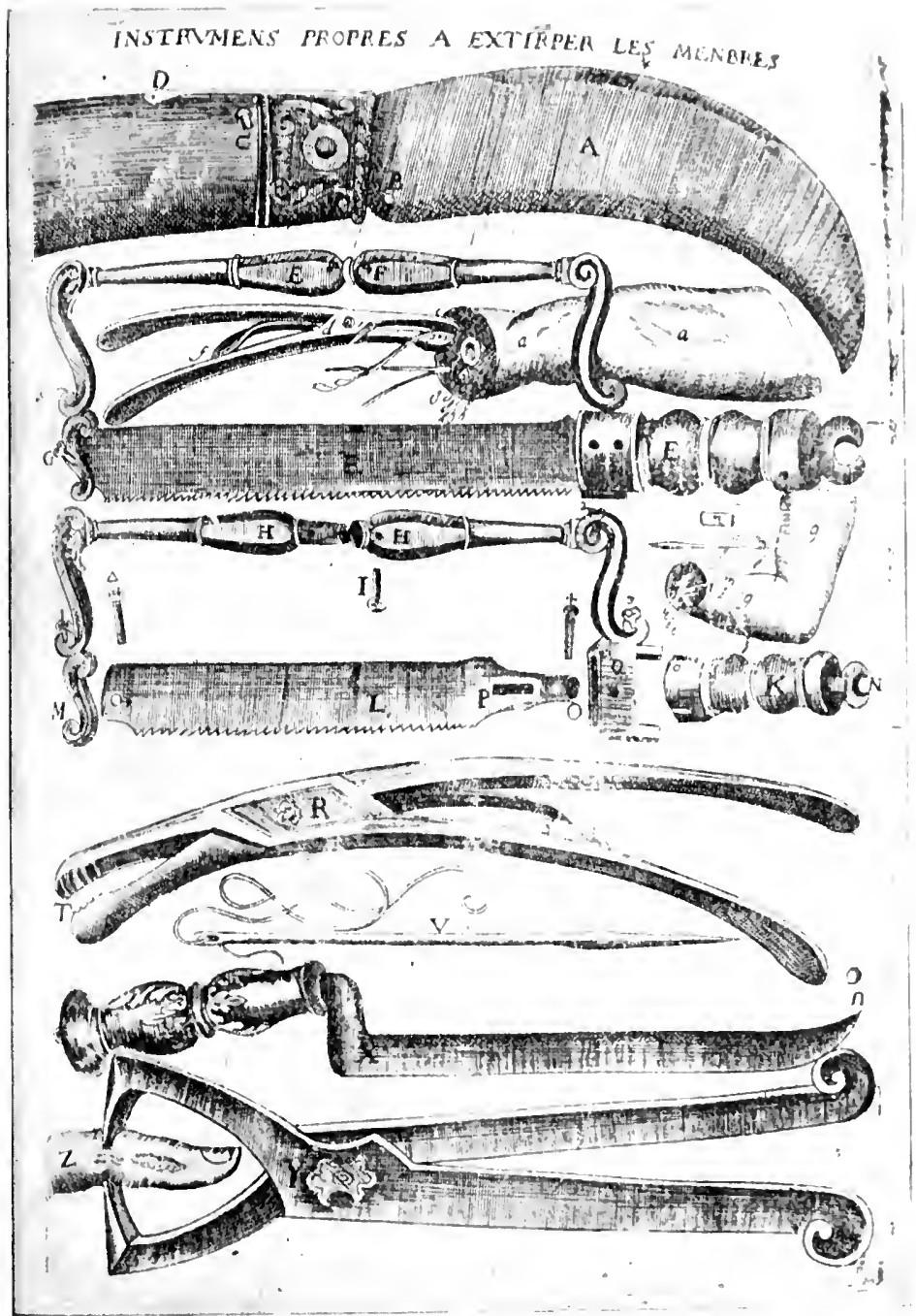

Fig. 19.-AMUTATION IXSTLIMFATS.

This phate shows knives, saws, and pliers, and alsu those hy which hamorhage was arrested without use of the cautery.

(From the Wurks on Chirurgerie, ly Jatenes Guillemeau, chirurgeon ordinary to the King of France. 1tit9.) 
was developed spontaneously in Europe toward the close of the sixteenth century, others that it was imported from the New World, others that it had a most ancient origin, and others ret that it represented a degenerated form of leprosy.

Cirtain it is that syphilis appeared almost simultaneously in all parts of Europe,-at Bologna, Halle, Brumswick, in Iombardy, Apulia, Auvergne, and so on. léonicenus attributed this sudden outbreak to an extraordinary inundation that occurred in all parts of Italy toward the close of the forrteenth century, and supported his views with the anthority of Hippocrates and Galen. Others attributed it to astrological influence; while still others regarded it as a scomge of God with which to pmish men and turn them away from unbridled libertinism. Fallopius thought venereal disease was engendered by the poison which the perfidious Neapolitans had thrown into the wells from which the French drew their water. These wild riews simply indicate the spirit of the age. Oriedo published in 1545 a history of the West Indies, in which he states that syphilis originated in Ameriea. He held that when Columbus returned from his second expedition to the New World, in 1496, his men enlisted muder Gonsalvo de Cordora to go and fight the French, whe had invaded the Kingdom of Naples, and that they communicated to the French and Neapolitans the disease which they had brought from San Domingo. Unhappily for his veracity, it is certain that syphilis broke ont in Naples at least two years before the arrival of the Spanish fleet. It is equally certain that at none of the points at which Columbus touched on his return from his first expedition was there any manifestation of syphilis for years.

It this time the renercal disease, so-called, included those conditions which we now differentiate under the names of syphilis, chancroid, and gonorhœa,-a confusion 


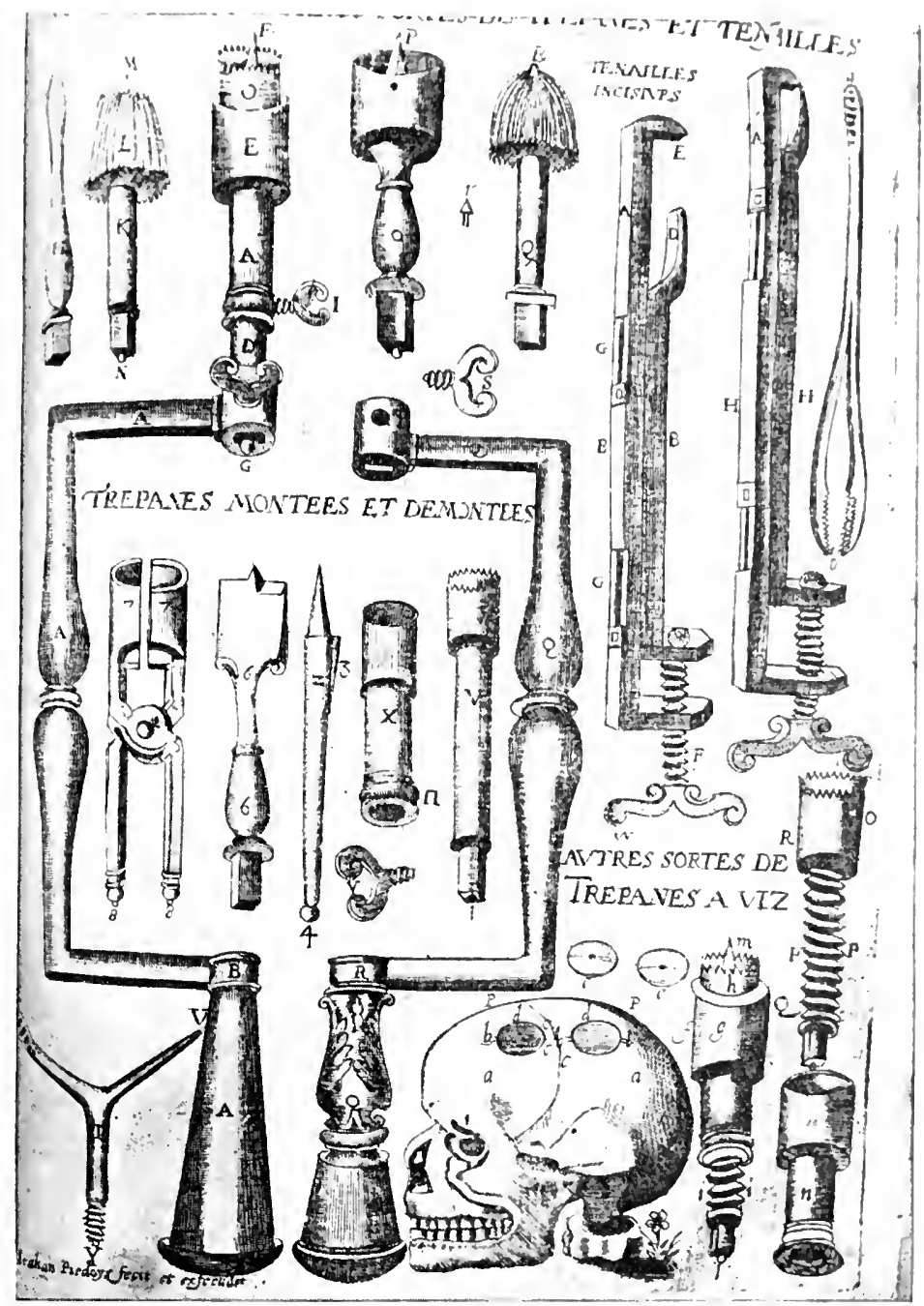

FIG. 20.-DHFFERENT FOLMS OF TREMHINES ANU PLIERS.

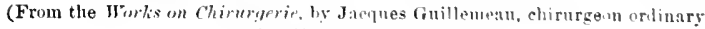
to the king of France, litw ) 
of diseases which persisted even up to the time of John Hunter. It is worth while to publish this fact, since writers of two or three hundred years ago may not have meant by the ferm "syphilis" just what we would mean to-laly. Withont going into this question liere, it is chomerl to sil that one who reads intelligently may see in the sacred seriptures unmistakable allisions to this disease. If the statements of David, as contained in the Palms, are reliable, he was himself a serious sufferer from it. 'The ancient Greck and Arabian physicians make mention of lesions which could only be attributed to this discase; and the latin satirists, like Horace and Juvenal, describe symptoms of a certain kind as being the fruit only of shameful practices.

It is most likely that the sudden appearance of syphilis in nearly all parts of Europe at about the same time, which has been regarled as so extraordinary, can be explained by the clearer distinctions plysicians began to make between symptoms of this disease and those of leprosy. Arrangements for the cure of lepers were very complete, and such syphilitic patients as responded kindly to the treatment thereby established themselves in a very different category of disease.

The first writer to systematically consider venereal disease was Astruc, who was born in Languedoc in 1684 and hed in 1766 . He was the principal adrocate of the view that syphilis had an American origin, in which view he was bitterly opposed by Sanchez, a Portuguese physician, who collected a large amount of evidence to the effect that Its first ravages were observed in Italy.

Summing up this whole matter, we may agree with Jomdan, who has examined all the opinions of these writers, and who, in his treatise published in 1826, conchuled that all symptoms which had been hitherto connected with syphilis had been known and described from the remotest antiquity, but were not supposed to 
proceed from a common source, and to be attached to the same cause, until after the close of the filteenth century.

TIIE INFLUENCE OF THE OCCULT SCIENCES ON THE MEDICINE OF THIS PERIOD.

Most of the partisans of occult science were restless minds, such as are found in all ages, who chafod under the yoke of authority, and who practiced as well as deduced their lines of thought and conduct in accordance with their own ideas. Some of these mon did not lack in sagacity, imagination, or anclacity, but almost all of them lacked in consistency of idea and dignity of thonght. Most of them lived isolated lives, apart from each other and from the rest of the world, and were, to a larece extent, what we would now regard as "cranks." While they made a wide departure from accredited doctrine, they depended upon imagination rather than upon reason. This happened to be a period, however, when such men achieved great notoriety,-more so than the same class of individuals have done since their time.

Cornelius Agrippa (born in 1486) was an early promoter of occult science. He came of a noble family of Cologne, received the best education of his time, was a man of varied attainments, great inconsistency in conduct, and a caustic humor which everywhere made lim enemies and prevented him from having any settled abode. He wandered from place to place, sometimes honored with the favor of the nobility and sometimes plunged into extreme misery. He early became a secretary in the court of Emperor Maximilian I, and under that monareh distinguished himself in the army by such bravery as to win him spurs as a knight. Soon disgusted with the profession of arms, he deroted himself to law and medicine, but his intemperate pen soon drew him into quarrels and persecution. At Dole he fell out with the monks; 
at Paris and 'Furin he compromised himself with the thoolocians; at Mot\% he incurred the animosity of the Jicobins for attaking the prevailing opinion that St. Ann had three husbands. He became a ragabond and almost a becrase in (iermany, England, and Switzerland, and then went to Ixons, where the mother of Francis I. Who was then (Queen Regent, made him her physician. He soon lost favor here, and was disgraced and banislied; then he wont to the low Comntries, where he was imprisoned on aceount of his treatise on The Vanity of the Sciences. Afterward he retmmed to Lyons, was imprisoned anew, for an old libel against his former patron. and finally died in the hospital of Grenoble, in 1535, at the age of about fiftr. Ilis treatise on The Trumity of the Srienres made him most trouble, and showed best both his bitterness of spirit and the extent of his leaming. Herein he laid down the paradox, which was later renowed and sustained by lioussean, that there is nothing more pernicious and injurious to common life, or more pestilential to the salvation of souls, than the arts and sciences. He fomded this thesis on Scriptural authority, and supported it by profane testimony.

The conchusions which Agrippa drew were not so strange to the eyes of his contemporaries as they are to ours. Long before him, men of character and attainments, such as lic de la Mirandola and Bessarion, had attempted to introduce the Platonic idea, that the best means of acquiring science and truth were introspective. 'They were, moreover, persuaded that a great number of phenomena and events lave their origin in astral influcuces. From this șistem to the extravagance of the Cabal*

* "ulat, or Kabbulal: A theosoplifeal or mystic speculative system, of Hebrew origin, which flourished fom the tenth to the sixteently century. It ineluded a mytic thensmlyy and comogony, attributing to deity neither will, desire, nor s.tim, but teaching that from it cmanated wislom, graee, intellect, power, beauty, fimmess, and ollor attributes. It also ascribed hidlen meanfugs to the sacred llebrew writings and Worls. Even in the letters and forms of the sacred words 
is but a step; indeed, the Christian doctrine, that events and phenomena are influeneed by the direct interrention of the deity or of the devil, is but a small transposition. The eabalistic theory, summed "p, was that all the events of life and all the phenomena of nature proceed fiom influences which gods, devils, or the stars exercised on the "archetype" - that is, on the essential spirit, or substance. He who conld withdraw his spinit possessed supernatural faculties. 'The day and the hour of birth, according to this view, were under the domination of particular stars, and each of the principal members of the body was supposed to eorrespond with some planet or eonstellation. 'T'his is the fundamental idea underlying the pictures-which are still to be found on almanics used by quack-morlicine firms-of the individual whose interior is so completely and uncomfortably exposed, while around him are arranged the signs of the zodiac, with indications as to which part of the body is governed by each.

Occult philosophy, built upon this foundation, was divided into four branches: theosoplly, to which a man raised himself by prayer; magic, or the art of controlling demons; astrology, or the art of reading future events by the stars; and alchemy, which teaches the secret of extracting the essence or the archetype of substances, i.e., virtually the secret of the philosopher's stone, by which metals were to be transmuted and then abolished.

And so the errors of science, the prejudiees of the superstitions, the excitement of the religious, and the cupidity of the rich and powerful, all concurred to propagate the faults of the cabal at the close of the Middle Ages. Never were there seen so many sorcerers, astrologists, and alchemists; never were prophecies, risions, and prodigies so common. Whatever happened, it was pre-

the followers of the cabal pretended to find wonderful and hiden meanings; hence the modern expression "crbalistic." The trachings of the calal were esoteric, of course, and ineulcated mysticism and ocentism in everything, but appear to have been more or less inlluenced by neoplatonism. 
tended that it had been ammonnced by some previons sign, or that it was a revelation of the future. 'This particular kind of folly persisted in Germany longer than in any other part of the world. Even Martin luther seemed to shape mally of the cabalistic riews, and his alleged strugerte with the devil. his adrentme with the inkstand, and so on, contributed much to spread them, and were, perhaps, the most pominent illustrations of their general acceptance. Sincely, these reve the Dark Ages.

Jerouse ('ardan was hom at Pavia in 1501. His life, like that of Aeriples. was one of rieissitude and ineonsintency. Being the idol of his mother and the detestation of his fither produced a peruliar effect upon his character. When he began to study he made rapid progress, and at the are of twenty-two was able to discuss publicly all questions. Ahout two years later he received his doetor's hat. Ile practiced medicine in varions places mutil he was thinty-there, and was then made professor of mathematirsat Milan. He ocempied this position but two years, then traveled in Germany. France, and England, and retmoning to Italy was imprisoned for debt in Bologna, and finally obtained a pension from the pope, in lome, where he died in 1556 . Ile was a man of great attain. ments and sagacity; his literary style was dignified, and, if he had not developed such a taste for the marvelous, such inconcejvable eredulity and superstition, and such vanity and boasting, he would hive been a remarkable character in his age. Leilnitz said of him: "Notwithstanding lis faults. ('ardan was a great man and, without his defeets, wonlel have been incomparable." He wrote extensively on philosophy, mathematies, and medicine. Sometimes he admitted to his writings the most absurd statements of risions. etc... and again affirmed that he had never deroted himself to cabalistic art, blamed those who practiced it, and jecred at those who believed in it. He wrote extensively on chiromancy. For his own follies and misfortunes he 
apologized, attributing them all to the influences of the stars.

The most colossal figure in this collection of medieval charlatans and knaves was paracelsus. He was borm in 1493, near Zurich, of a well-to-do family, his father being : physician. He had a good preliminary aducation, and then visited the various unirersities, or rather university

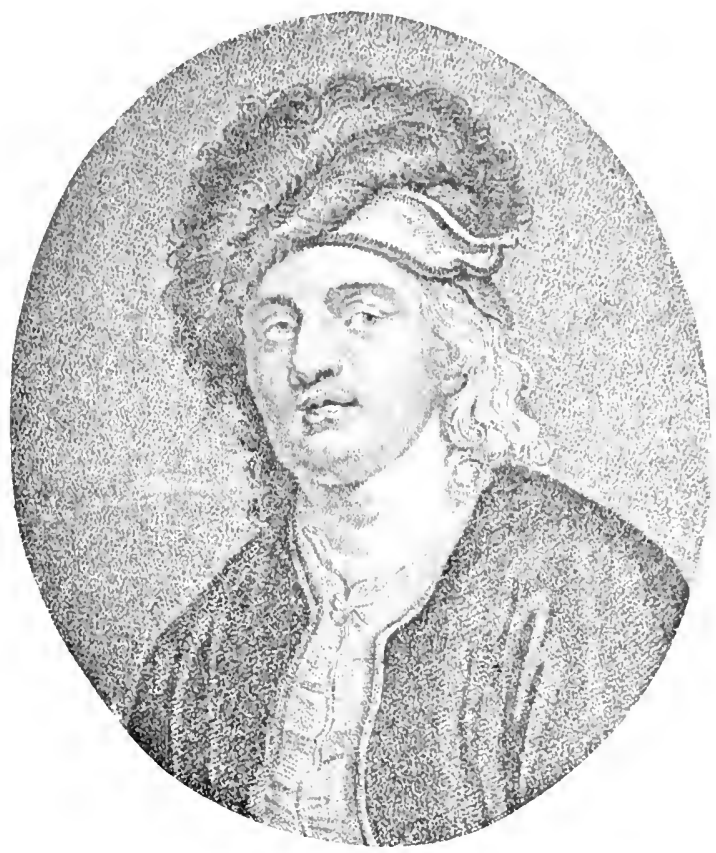

Fig. 2l.-Pinlip Tileopinastus paracelasus.

(From an old engraving ly Ridley.)

towns; but, instead of listening to the professors, Paracelsus associated with clever women, barbers, magicians, alchemists, and the like, from whom he acquired much information. He was led at once to the vagaries of the cabal. and, according to his own statement, he did not open a book for ten years. He neglected his studies and forgot his Latin, so that he became incapable of expressing him- 
self in that language. From the age of twenty-five he became a hard drinker, and this habit ultimately worked his ruin. One of his disciples says of him that during the two rears which he passed with him he was so inclined to drinking and debanchery that he could searcely be seen for an hour or two without being full of wine, although that condition did not prevent him from being admired by every one as a second Eeculapius.

At this time Paracelsus was between thirty-three and thirty-five years of age, and at, apparently, the most brilliant period of his life. He had written extensively and with emphasis of his numerous cures, after the fashion of charlatans of those days._and, unfortunately, of to-day,and claimed to be possessed of infallible secrets against the most intractable disenses. He had just been called to Basel to the chair of physic and surgery, and crowds of curious and idle persons attended his lectures, which he gave in the remacular, and not, as was customary in those days, in Latin. In order to strike his anditors with astonishment. lie began by burning the works of Galen and Iricemna, and then reading from his own writings, breaking off from time to time into the statement: "Know, ye ductors, that my hat knows more than you; that my beard is more experienced than your academies. Greeks, Latins, Arabians, French, Italians, Jews, Christians, and Mohammediuns, you must follow me; I shall not follow you, for I am your monarch, and sorereignty belongs to me." As may be imagined, his professorship was not one of long duration, and he soon had few or no listeners. In consequence of some mishaps he left Basel quite precipitately, lis departure causing $n$ o such sensation as his arrival. $\mathrm{He}$ then resumed his nomadic life, and we find him at Alsace in 15\%8, at Nuremberg in 1529, at St. Galle in 1531, at Mindellicim in 15t0, and in the following year at Salzburg, where he died in the hospital at the age of forty-eight. Few men there are of whom so mich good and so 
much evil has been written as of Paracelsus. Few are there of whom it is to-day so hard to judge, since, if we refer to his contemporaries, they disagree completely concerning him, and if we refer to his own writings we fall into still greater chaos and have to abindon the attempt. His writings show ideas without connection, observations which contradict each other, and phrases which defy comprehension. At one moment he gives proof of admirable penetration, at the next simply alject nonsense.

That he exerted an influence upon his time is cortain, but that this influence was retrograde rather than progressive seems quite likely. His exact duplicate has probably never existed since his time, and we may say that never was there another man like Aurelins Phillippus 'Theophrastus Paracelsus Bombastus ab Hohenheimhis full name.

Although this man was such a prominent character in his day, his name must be erased from the list of those who have contributed to the world's progress. Ife was simply a pretended reformer, who counted as nothing the most erudite writings, and who relied solely on his own experience. He had the most profound self-contidence, and played upon the credulity of his neighbors and victims with the toys which were furnished him by the prevalent cabalistic notions of the day. The school which he would have founded was nothing but a school of ignorance, dissipation, and boasting-a school of medical dishonesty. In a word, it was, as Renound has said, "a school of which Thessalus, of Tralles, had been the Corypheus in antiquity, which John of Gaddesden revived in the Middle Ages, and to which Paracelsus gave a new development."

While, as has been briefly recounted. the partisans of the occult sciences strove to completely overtum the scientific edifice of antiquity, other reformers, more sen- 
sible and less daring, wore content to expose its defects without attacking it in its entirety. These were, for the most pirt. enlightened men, and at the same time free thinkers.-liriends of progress, and not of destruction. 1)urng the sixtcenth century these men were few in number, but at least three or four of them deserve mention.

John Aronentier was born in Piedmont, and taught in Nipules. Pisa, and 'lurin. He did not hesitate to take issue with the theories and statements of Galen, and criticised those who alopted them too servilely. Of him it ma be said that. although styled a reformer, nevertheless, he kept too near to the doctrines of those against whom he inveighed to seriously weaken their position.

l,onard liotal, also a Piedmontese, was born in 1530. First a surgeon in the French army, he later became physician to the kings Charles IX and Henri III. He was the first to recommend frequent and general bloodletting. Apparently before his time this practice was greatly restrained. Ile carried his views so far as to maintain that an infirm old man should be bled from two to six times a year, and that it was good custom to open the reins of healthy individuals every six months. He wrote a remarkable memoir on the cure of disease by blood-letting. It is not to be denied that he obtained some remalkable success with his copious venesections, and it must be said, in lis defense, that, if he overdid it. his contemporaries did not resort to it often enongh, and that his own practices were instructive to others. In his witings he mited independence and energy of thought with cleagunce and purity of style.

Jombert (15:29-1583) was ('hancellor in the University of Montpellier and physician to King Henri III. He wrote a treatise on Popular Errors, which had an unheard-of success. In less than six months there were sold nearly five thousand copies, which, considering the 
times, constituted a prodigious adition, For one thing, it was written in the common tongne, and so placed within the reach of all. It was also diversified with aneedotes and jokes, some of which were not of the most delicate character; in fict, the author endearored to atone for some of its salacity by dedicating it to (2uecn Marguerite. He really proposed for his main purpose a serious and useful one,-namely, that of combating prejudices which were both injurious and ridiculous. Although we may make light of Joubert's treatise, it certainly achieved a useful end by dissipating a multitude of errors, giving information to those who could scarcely get it as well from any other source. 'That it was full of defects is simply another form of saying that it was published in the middle of the sixteenth century.

It was during this period of which we have written that the separation of the priesthood from medicine was completed. From the sixteenth century celibacy was not obligatory on physicians in the Kingdom of France, and they no longer enjoyed ecclesiastical bencfices. At this time, too, surgery, which had naturally been separated from medicine, began to approach it, the combination thus gradually brought about inuring to the benefit of all concerned. From now on, the professors of St. Côme were on the same level as the professors of the university, and enjoyed equal privileges. Institutions for instruction in medicine increased, and those which already existed were developed. Amplitheaters for dissection were open in every city in Europe. Hospitals and dispensaries were established alongside the schools, and by the various governments more attention was paid to the protection of the public from imposition, and to the amelioration of every evil affecting either public or private health. 


\section{CHAP'TER VI.}

A(iE OF RFXovitus (comtinual).-Student-life During the Fifteenth and

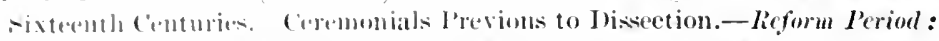
'lhe soventernth, lighteenth, and Nincteenth Centuries. Modern Realism

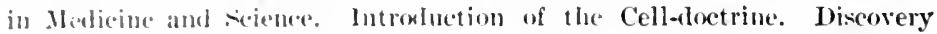
of the Circulation. William Harver, 1.5\%-163\%. Malpighi, 1628-1694.

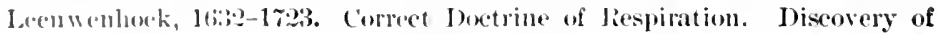
Ihe Lymphatic (ireulation. The Xerwous system. I iscovery of Cinchona. 1).eropment in Hstetric Art, in Mledieal Jurisprudence, in Oral Clinical 'leakhing. Van Helnunt, 15\%-1611.-The Iatrochemical System : Le Böe, 1614-l6i2. Thomas Willis, I6\%2:-1675.

For a long time the Italian universities held the first rank; next came the French; and last the German, although all were well attended. The most famous were the medical faculties of Bologna, Pisa, Padua; then Paris, Montuellier, and, finally, Basel.

A little of what concerned the student-life of this period may not be amiss. The students chose the rector and officers of the universities, sometimes even the teachers, and assisted in determining the curriculum of study, the execution of which they watched. In some of the scotch unirersities even now the students choose the rector.

'The students were divided, usually according to comtrỵ, into bodies denominated "nutions" (some having special seals), which were the parents of the present student-corps in German universities. Certain representatives, known as rice-rectors, were chosen from each of these corps and constitnted a so-called college of rectors which negrotiated with the officials of the State, and posseswed a power that was preserved until the end of the sixternth century.

The poorer class of students passed from one school to annther, supporting themselves by singing, begging, or stealing, and were sometimes guilty of great barbarities. 'The younger scholars, called "Schützen," were compelled 
to perform most menial duties for their older comrates, the "Bacchanten,"-much like the system of fingring still in vogne in English grammar-schools; and when the bacchantes were admitted to the miversity proper they were required to pass through an initiation, or hazing, which eclipsed anything known in these days; indeed, the antiquity of fagging may be traced back even to the philosophic schools of Athens. 'The habits of the traveling scholars led many of them into dissolute and vicious ways, though some attained respectable positions, - possibly even eminence. The students who were better situated financially, for the most part entered the Italian unirersities.

Already mention has been made of the enormons number of students congregated during this age in Bologna and in Naples. In the small University of Wittenburg there were, in 1520, only about six hundred students; in Erfurt, three hundred, and this number dwindled two years later to fifteen; in 1500 Leipzig had four hundred students; at the same time there were about seven thousand in the University of Viemna. Students and teachers migrated from one place to another, and faculties were constantly changing. Great teachers were received with great ceremony. Bitter struggrles and disputes between teachers sometimes occurred; it is related of Pistorius, who clicd in 1523, and Pollich, deceased in 1513, that they conceived a violent enmity toward each other because of antagonistic views relative to the epidemic or contagions character of syphilis, and both ultimately left leiprig for other schools.

Some curious customs prevailed. In teaching anatomy, while the learned teachers explained the parts as exposed, the dissections were left to barbers as being unwortly of an educated medical gentleman. While the cadarers were mainly the corpses of executed criminals, it was thought that before and after each special dissection religions ceremonies were appropriate, and such were often held; it was also believed that all who came in contact with such a 
corpse would he made dinceputable muless it were itself tirst male repulable; hence the professors first read alond a decree to that effect fiom the magistrate, and then, by order of the semate of the litenlty, stamped "pon the breast of the compe the seal of the university. 'Jhe body was next carried into the anatomical hall. and the cover of the hox in which it had been transported was returned to the executioner, who remaned at some distance for this purpose. If the rorpse was one that had been decapitated, during these solemn remonies the head was placed between its legs. Finally, an entertainment with music, often fumished by itinerant actors, was giren. But this folly was gradually discontinued, and by the second half of the sixteenth rentury public dissection was performed withont recourse to such mummeries. 'The price of sheletons in those dars was high ; the University of Heidelberg, in 1669 , paid serenty-two dollars for one.

The practitioners of the sixteenth century were often quite as roving as the students and professors, though those who held positions as State phrsicians were bound by contract to a tixed residence for a certain time. In 1519 the State pliysician of 1 Ieilbromn received a salary of twenty-one dollar's per year and his firewood, but could not leave the city over night without permission of the Inrgomaster. Medical attendants of the King of Spain were required to kneel down when they felt the king's pulse. 'Ihere were few physicians who acquired wealth, althongh Fabricius ab Aquapendente left a fortune of two hundred thonsand ducats.

'The Reform l'eriod is the name which Renouard has given to the time beginning with the commencement of the seventeenth century, - a time when the domain of natmal science was daily enlarged, and when observation had enrichod luman knowledge with multitudes of new facts, some of which harmonized with, and some of which were in opposition to, prevailing doctrines. Men whose 
knowledge equaled their genins began to need a ratimat reform, and by such men intellectual improvenent was begm by which the decrepit theories of the sehools of the Middle Ages were eratlicated and by which there were substituted for them others which harmonized much better with known phenomena. To the period of workhip of ancient anthority succeded one chatacterized by a desire to shake off the yoke of the same, and men now struggled, as it were, to free themselves from the tyranny of the past. As Galileo was the torch-bearer for regeneration of the knowledge of physics, and as Kiepler, and others already named, or to be nameá, did as much for other branches of science, so there were not lacking those who broke away from the restraint of anthority in medicine, and began to beat or choose paths for themselves among the facts which experimental science furnished them.

With the approach of the serenteenth century there was evident improvement in both the social and mental status of medical men. While political humiliation and exhaustion were everywhere noted, in the field of literature it was evident that the line had advanced. What may have been the effect of thirty years of religions war, with other political struggles carried on under the hypocritical cloak of religion, may be imagined, if not fully described; the devastation of whole countries by disease, and notably by the plagne,- the porerty and hunger consequent upon the ravages of perpetual war (it is stated that even so late as 1792 there were still in Saxony 535 wasted and extinct villages), to say nothing of the barbarity and immorality resulting therefrom,-all combined to make the early part of the seventeenth century a most mournful epoch. It is not strange that, with poverty, superstition and great rudeness of manners prevailed, or that trials for witcheraft and persecutions by the Jesuit Inquisition were common. That any adrance 
should have been made under such circumstances speaks well for the progress of the human mind. That this adrance was slight in Germany and central Europe is not strange, though other comtries were able to quietly enlarge their scientific borders. Now it was that England, Italy, and the Netherlands, which took but little part in the warlike struggles of the century, acquired leadership in medicine, and were seconded by the French. In Gireat Britain, science had been fostered by varions kings, and particularly by (harles II, who professed to be something of a chemist; in firct, an epidemic of scientific interest fell upon the English court.

'The screnteenth century, in contrast to the idealistic sixteenth, witnessed the advent of modern realism in almost all departments of thought. Medicine furnished the first example in what we are accustomed to-day to speak of as the exact method; hence, the century is of great importance, in that physicists and chemists began to be original, instead of mere followers of the past. The most notable feature of medicine was the promulgation of three medical systems: the pietistically colored l'aracelsism of Van Helmont; the chemical system of Sylvius; and the iatrochemical system of the physicist and mechanician, Borelli. This period is, moreover, illumined by the life of one great practitioner, whose name will be imperishable in the history of our art,-namely, Sydenham.

The principal tendency of the time was toward skepticism, which had begun in the preceding century with Montaigne, and was continned by Charron, under the patronage of Queen Marguerite of Navare; it was the fundamental idea of Pierre Bayle, the author of the great dictionary. Opposed thereto was the supernatural philosopliy, or the theosophic, cabalistic, or mystic. The leading exponent of the latter was Boelıme, who was a business colleague of the celebrated "Meistersinger," Hans Sachs, in Germany, and of Blaise Pascal and his contemporary, 
Malebranche, in France. 'The doctrine of Lord Pacoun, Lord Verulam (1561-1626), a man who showed himself as exalted in mind as he was mean in personal traits, was of great importance Bacon is a landmark in listory as the defender and eulogist of modem realism,-i.e., of inductive philosophy. While personally contributing but little to the alvance of science, he tanght a great method; as Gruen says, he was the philosopher of patents and profit; he recognized the compass, the art of printing, and gunpowder as great inventions, but placed little value on the discovery of Copernicus, having little comprehension of mathematics. Hobbes and Locke went farther into realistic philosophy, and the latter was an exponent later of pure empiricism

In the seventeenth century, also, zoölogy and botany were largely extended. In it lived Swammerdam (16:37 $-168($ ), famous as a naturalist, plrysiologist, linguist, poet, and savant; there were others, also, whose names are better known in the history of collateral science than in medicine, and who left conchusive demonstrations in accordance with their theories, and made daily use of the microscope, simple as it then was. 'T'he term "cell" had been introduced by Hooke in 1667, and Malpighi and Grew were the founders of the cell-doctrine. The astronomical laws discovered by Copernicus changed the course of the world's thought; and now appeared the brilliant Kepler (1571-1630), and Galileo (156t16+2), the defender of the Copernican system, and the persecuted discoverer of the law of falling bodies, of the thermometer, the telescope, and the movements of Jupiter; also, Sir Isaac Newton (1642-1727). whose discovery of the laws of gravitation in 1665 marked an era in the history of science. This century, too, gave birth to Römer, who in 1675 calculated the velocity of light; Huygens (1627-1693), who discorered the polarization of light and the satellites of Saturn; James Gregrory, who in 1663 
male a reflecting telescope with a metallic concave mirror; 'l'orricelli, who in 1643 motsured the weight of the air; Gascoigne, who invented the micrometer in 1639; and Nippier, who inrented logarithms in 1700 .

Now chemistry, having ceased to be alchemy, began to don the dignity of a science per se, and it may be chimed that medicine derived no slisht benefit therefrom. Sicientific societies and journals arose at this period, and were all of good service to medicine in thein way. 'The church scented danger to the faith in everything which related to natural science, and founded certain secret associations, especially in Italy; the Aceadenia Degli lincei. so called from its seal. which bore the image of a fox or lynx. foumeled in lome in 1603, was one of these. Comber-societies, or, rather, socicties with opposite purposes. were also started, and the original and private so-called Invisible society. which was orjginated mainly by Milton, in 1645. and remodeled by Clanles II in 166:, is now the flomishing Royal Society. In France the Academy was fomeled in 1665 by Colbert, but developeel its first real activity thirty-five years later.

'Those who to-day are so familiar with the course of the cinculation of the blood through the arteries and veins find it difficult to muderstand how the recognition of this phenomenon conld have been so long delayed; it seems so simple, yet to thie ancients it was perfectly imcomprehensible! Althongh every one lat recognized that blood would flow from an incision. few stopped to reason therenpon. From time immemorial it had been supposed that the reins had their origin in the liver, and were the only rescols which contained blood, since the arteries were alway found empty after deatlı; the latter were held to contrin only air or spirit. 'The eirculation was supposed to leave and return to the liver though the venous canals ly undulating movements similar to those of the wares of the ocean; and this was the doctrine of the 
Asclepiadie, and probably of Erasistratus. Galen modifionl this view by showing that the arteries contanined hlood; he knew it was poured inte the right ravities of the heart by the great veins, but he believed that only a small quantity passed from the right ventricle into the lungs, and that the major portion reached the left rentriede by passing through pores in the inner ventricular septum. 'This opinion was uncontested until the middle of the sixtcenth century.

Then the theologian, Michacl Servetus, who, in 15.53, perished as the victim of Calvin's jealonsy, denied the passage of the blood through this septum, contending that it was returned from the lungs to the left side of the heart by the pulmonary veins. This was a happy thought, and a great step toward the truth. Soon after Columbus demonstrated anatomically that the conjecture of Serretus was plausible, by showing the function and real use of the valves of the heart. Cesalpinus came still nearer to the truth, and explained, as did Columbus, the course of the circulation through the lings, but he opined that blood and vital spirits passed from the arteries into the veins during sleep, because at that time there was swelling of the latter and diminution of the pulse. Valres in the veins were known, and it had been shown that ligature of an artery in the living animal stopped the flow below it, while if a vein were tied there was shrinkage above the ligature, and swelling below it. Snch was the state of science at the begimning of the seventeenth century; there remained, practically, but one step to take,- to find the true course of the blood.

William Harvey was born in Folkestone, Kent, in 1578 and died in London in 163\%. He first studied at Cambridge, entering at the age of fifteen; subsequently traveled in France, Germany, and Italy, remaining in Padua from 1599 to 1602 , in order to hear the lectures of Fabricius ab Aquapendente. With the title of "Doctor" 
he returned and setted in London and soon became a nember of the ('ollege of Medicine, of which he was made a regent in 1613; in time he became physician to James I, and, on the demise of this sorereign, to Charles I; to the latter he dedicated his chief work. During the civil war he was driven from place to place, and, finally, to Oxford, where he surendered himself to the Parliamentary troops, alter which he again resided in I sondon with his brothers,

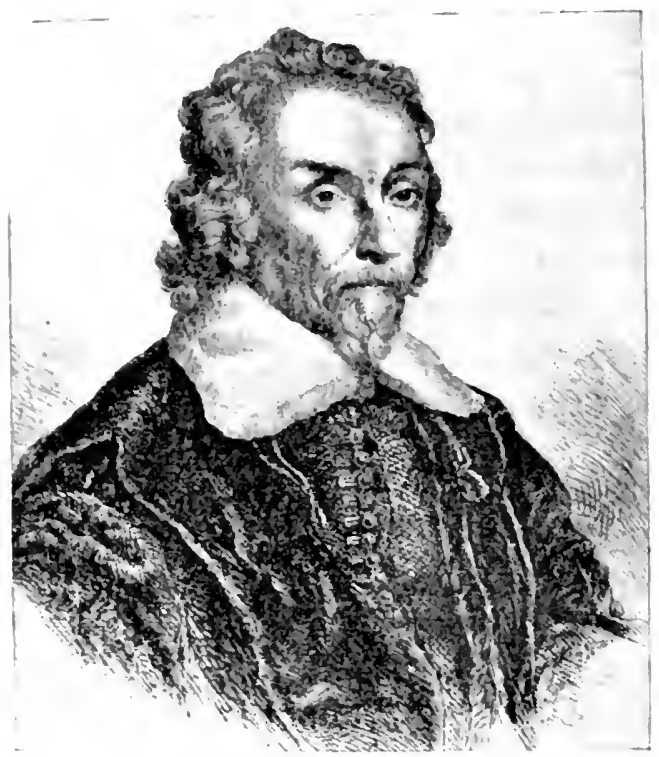

Fig, on-WILliaM HARVE, M.D.

(trom a wordeugraviag of a fainting by Bemmel.)

who had become rich. Modesty led him to decline the lingh distinction of President of the College of Plyysicians, and he lived a quict and retired life, occupied with his studies and, in lis later years, investigations in mathematics. Soon after 1613 he began, through his lectures, to make known the doctrine of the circulation of the blood; but he did not publish the results of his researches until 1628 , after submitting them to fifteen years of proofs and counter- 
proofs of every kind. So bitter was the opposition of his contemporaries to the new doctrine that he at one time lost a part of his practice, and was even lucld to be demented. It is characteristic of the fate of new truths, as well as of that age of dominant anthority, that his first publicationConcerning the Motions of the ITeurt and the B,hort_was nuable to pass censorship in Gugland, and therefore appeared in a foreign conntry (Fankfort, in 1628) when he was fifty years old; but his second treatise on the same subject, in reply to Riolan, a protessor in the Jalculty of Paris, was published in Cambridge in 1649.

"So much care and circumspection in search for truth, so much modesty and firmuess in its demonstration, so much clearness and method in the development of his ideas," says Renouard, "should have prepossessed every one in favol" of the theory of Harrey; but, on the contrary, it caused a general stupefaction in the medical world, and gave rise to great opposition."

This theory, which to-day appears so natural that we conceive with difficulty why it was not sooner discorered, was nothing less than a revolution in plusiology; it excited a tremendous controversy that continued more than twenty-five years, and in which mingled every one possessed of any pretension to kuowledge of anatomy or physiology; even naturalists aud philosophers took part in the dispute. René Descartes was the first to declare in its favor and to support it by experiment; John Walaus (Jan de Wale), the celebrated Professor of Anatomy in the University of Leyden, confirmed it by new observations; finally Plempins, of Louvain. for a time one of the most fiery of opponents, succumbed to the truth, and in 1652 passed publicly to the raulis of Harvey's followers-no small triumpli!

During these long debates Harrey remained always dignified and firm, although the early attacks rendered him unduly sensitive regarding others which he anticipated. 
About his only answer to the alguments adduced against him, was to add new proofs and new experiments to those alleady pulished. 'The only one of his adversaries who obtained a direct response was Riolan, who possessed immense influence among his contemporaries as a man of attainments; liolan (combated with equal violence and obstinacy the other great discovery of the age,-riz, the circulation of the lympl. Harvey ultimately: howerer, had the satisfaction of secing his theory unversally adopted. But his services were not limited to this one discovery. In made most interesting observations on gencration, both in man and in animals ; on midwifery; and on the structure and cliseases of the uterus.

The intermediary system and bond of union between the arteries and reins, so very essential, yet up to this time mulinown, was discovered by the great Malpighi, who was born in 1628 near Bologna. became professor in its miversity, and discovered in the lungs and mesentery of frogs, in 1661, the capillary eirculation. He first described the corpuscles of the blood in 1665 ; Ine also discovered the hungcells, as well as the cutaneous glands, certain portions of the kidney, and the pigmentary layer of the skin, named after him (rete Malpighi), which later furnished the first explanation of the difference of color in different races.

In 1690 Icenwenhock (1632-1723), who lat been making observations on the larve of frogs and other small animals, was able to see with his improved microscope the movements of the hlood in the small resscls, and gave the important testimony of his observations. In I687 Cowper saw the passage of the arterial into the venous current in the mesentery of a cat. The capillary connection befween the two rasenlar systems was first demonstrated by Marchetti. lut was best shown by Ruysch (1638-1731), professol at Amsterdam, the famous inventor of minute injections. who grcatly advanced anatomy by the formation of collections, one of which was brought into Russia 
by Peter the Great at an expense of about serontr-five thousand dollars. 'The liussian transporterss of the collection, however, drank the alcohol in which many of the preparations were preserved, and a portion of the sperimens was thus ruined.

Further illustration and amplification of IJarvey's virws came fiom various sources; the last, perlalps, from Nicholans Steno (1638-168(i), who was first a professol in Copenhagen, then a bishop and peripatetic converter of heretics. Steno first proved the hount to be a muscele that contrats actively and expels the blood. 'The duct that bears his name was discovered dming his residrnce in Leyden or at Amsterdam. His name is written alio "Stenson."

While ancient anatomists were able to describe in a general way the form of the lungs, their location, consistency, the ring-like structure of the trachea, and the tirst division of the bronchi, they did not go farther, but blindly accepted the prevalent theory that the bronchial tulues anastomosed with the terminal pulmonary veins, and that in this way atmospheric fluid was conveyed from the respiratory organs into the heart. On such vague and erroneous data was construeted the theory that the air was drawn into the lungs by the heat of the heart, which was the reservoir of the vital spirits; that in penetrating through the smaller tubes it was rarefied, its thimnest part passing into the heart, where it served as material for the formation of the vital spirit, its grosser part being exhaled. In other words, respiration was supposed to have two purposes. one to refresh the lungs, which, being porous and intlammable, wonld otherwise take fire from the heart, or focus of animal heat; the other to furnish the pueuma, or ether, which was employed by the heart in the formation of animal spirits. Harvey's discovery upset all this, in great measure.

Next it was shown that pumonary reins carried nothing to the heart except blood. And now, during this Re- 
form Period, the purpose of the morements of the chest wals better studied. for Borelli, Helvetius, and Haller made many experiments, as the result of which it was determined that during inspiration the thorax is enlarged in all directions, and during expiration partly collapsed by relaxation of muscles, and that there never is any empty space between the lungs and the sides of the chest; finther, that air is diawn into the chest by the tendency of all gases or fhuids to maintain an equilibrium, or, in otlser words, because Nature abhors a vacumm. 'This being settled, various puemmatic theories were adopted and abandoned, all of "hich had subsequently to give way before a knowledge of what really occurs. The truth was conceived of by Mayow in 166s. It had been noticed that blood which appeared black in issuing from the reins, became red in contact with the air, and direct observation proved a similar change of color to take place during its passage from the pulmonary reins during life. Goodwin, opening the thorax of a frog, was the first to see this, and Hessenfratz filled a silk bladder with renous blood, and, plunging it into an atmosphere of oxygen, saw the blood change from black to red. In this way and by the later labors of Bichat and Lavoisier were clcarly established the mechanism and the purpose of the function of respiration.

'The discovery of the lymphatic vessels and their purpose was scarcely less remarkible than that of the circulation, though marked by less eclat because it was not the work of one man, but a matter of slow development. Herophilus and Erasistratus had seen white vessels connected with the lymph-nodes in the mesentery of animals, and supposed them to be arteries full of air. Galen disputed this, for he helieved that the intestinal chyle was carried by the veins of the mesentery into the liver. In 1563 Eustachius described the thoracic duct in the horse. In 1622 Aselli, Professor of Anatomy at Milan, discovered the lacteal vessels in a dog which had been killed immediately after 
partaking of food; having pricked one of these by mistake, he saw a white fluid issue from it. Repeating the experiment, he became certain that the white threads were ressels which drew the chyle from the intestines. Ite observed the valres with which they aresupplied, and supposed these vessels all met in the pancreas and continued on into the liver. In 1647 Peequet, while still a sturlent at Montpellier, discovered the lymph-reservoir, or receptenculum chyli, and the canal which leads from it (the thoraceic duct), which he followed to its termination in the left subclitrian rein. Having ligated the duct, he saw it swell below and become empty above the ligature. IIe studied the courses of the lacteals, and convinced himself that they all entered into the common reservoir. This discorery gave the last blow to the ancient theory which attributed to the liver the function of blood-making, and confirmed the doctrine of Harvey. Strangely enough, the latter mited with liolan in opposing the discovery of Pecquet and denying its significance. From this time the lymphatie ressels and glands became objects of common interest and were inrestigated by many anatomists,-lyy Bartholin, Ruysch, the Hunters, Hewson, and, above all, by Maseagni, who was the first to give a graphic deseription of the whole lymphatic apparatus.

The ancients confounded, under the name "neuron," nerres, tendons, ligaments, and membranes; even Aristotle regarded the brain as an incrt mass devoid of sensation, and supposed the nerres to originate in the heart. Rufus, of Ephesus, remarked that Herophilus distinguished three sorts of nerres, - the first serving for sensation and motion and proceeding from the brain and spinal marrow, the second and third serving to unite bones and muscles. Galen also shared in this error, but, nevertheless, described the brain-membranes and the difference between white and gray matter; he supposed the cerebrum to be the seat of the soul and origin of sensory nerves, and that the cere- 
bellum gare rise to nerves of motion; the pulsation of the cerebrum cxposed was held to be a sort of brain respiration. Galen came rery near recognizing the distinction between nerves and tendons, but nevertheless confused them. 'The anatomists of the sixteenth century described certain portions of the nerrous system with more exactness than did Galen, but not with such positiveness as to prevent ('esalpinus from renewing the Aristotelian theory that the heart was the origin of sensation and the seat of the soul. Nearly two centuries later Bagliri adranced a theory which referred vital morement to the heart and the dura mater.

The progress which accrued to comparative anatomy and phrsiology, and the experiments which were made on animals, during this period, shed a great deal of light upon the nervous system. The researches of Vieussens, Haller, Meckel, Vicq d'Azrr, Scarpa, Soemmering, and others had already rendered it manifest that the brain was the organ of sensation and voluntary motion, and Biehat had proposed to divide the nerrous system into cerebrospinal and sympathetic branches.

Now, too, liepler discovered that the erystalline lens was not the seat of rision, as had been supposed, but that its function, like that of other lenses, is the refraction of light. He observed that the image of objects is depicted upon the retina, and (with Scheiner) demonstrated that the expansion of the optic nerve in the retina is the essential part in the organ of sight. Obviously, also, interest in the anatomy of the eye, which these observations every. where stimulated, was, in a great measure, aided by the rescarrhes of Newton on lightit and color.

About this time, too, Cinserius and others studied the anditory appraratus and described the ossicles, the small muscles of the internal ear, and the semicircular camals; they cren followed the acoustic nerre. By the researches of a number of French and Italian anatomists it was like- 
wise established that the true seat of hearing lies within the internal ear, the extemal parts being merely of assistance in conducting somnd.

'Thomas Willis was one of the first to consider the brain as an assemblage of organs and to assign special functions to certain of its divisions; he thus becane at pioneer in cerebral localization, although most of his conjectures were inaccurate or finciful. The worlsings of the brain were also studied by Pincl and others, who observed that in certain conditions of mania or partial insanity some of the mental faculties-such as memory, judgment, imagination, or will-were abolished or suspended, while other fuculties were preserved; hence it was inferred that each faculty must have its own seat. The views thus enunciated were carried to an absurd degree by Gall, and later by Spurzheim, who made an entirely new classification, believing the craninm to be molded in a reasonably exact mamer upon the brain, and that, by inspection of the exterior, the character of a given individual could be read. 'They thus founded the psendoscience denominated phrenology, which we now know has practically nothing to justify itself.

About the middle of the seventeenth century Glisson (a professor in the University of Oxford) recognized a property pertaining to all living tissue, which he termed irritability, and which he regarded as sufficient cause for all the phenomena of life; he enmoliated certain riews that, in times past, have had an important bearing upon the pathology of disease, but which were forgotten for sixty years or more until revamped by the Dutch anatomist, Goerter It was the latter, with the great IIaller, who, by a series of very ingenions experiments, elevated the suppositions of Glisson to the dignity of demonstrated facts. In $17+\tau$ the results of Haller's researches were published under the modest title of First Lines in Plyysiolog!y; the author was, in fact, the great exponent of the doctrine of irrita- 
bility in neurophysiology, and for this deserres to be remembered wherever the history of our art is spolien of. This theory of irritability was applied to pathology by labre, of Paris, who refited the mechanical theory of Bocrhatre on inflammation, proving that the latter proceeds not from obstruction of the capillaries, but from exaltation of their irritabiity. It was also applied in many ways by Bichat, who enjoged a brief, though memorable, career. The theory of irritability, along with the truths established by John Hunter in his researches on the blood. made a very distinct adrance in the physiological knowledge of the serenteenth century, and the researches of those who contributed so much to its adrance are well worthy of study even at the present day. In this line of investigation should, perhaps, also be mentioned the names of Winslow, Albinus, the two Monroes, besides Vieq d'Azyr, and others already named.

I have so far discussed the development of theories and researches of individuals. During the earlier portion of the serenteenth century there happened something which gave to materia medica a remedy so raluable, and which attracted such wide-spread attention, that it deserves special mention. I refer to the discovery of that great febrifuge, l'eruvian bark. Malarial ferers had been known as early as the time of Hippocrates, and were unirersally treated largely with purgatives, sometimes with renesections. 'There had been no notable improvement in the management of prrexias of this class down to 1638 , when the Countess of Cinchon, wife of the Viceroy of Peru, became a prey to a ferer which nothing could remove. It is said a Spaniard learned from the natives the secret of the bark, and adrised its empiorment, whereby the countess recorcred her health. This is the generally received account, althongh it has been widely discreditcd, and Humboldt expresses decided doubts as to the source whence the first knowledge of the bark was derived. Be this as it may, 
however, it is certain that, in 1639, the comtess and her physician, de Vega, imported into Spain a quantity of ground Peruvian bark, and distributed it to various persons, though it was not made an article of general commerce until ten years later, when it was exploited by the Jesuits, who had received a large supply; in spain it was known as the "comntess's powder," and in Italy as "Jesuit" or "cardinal "powder. Being very highl-priced, it was soon so sophisticated as to be quite mmeliable. C'ondamine, the botanist, having been sent to America for other purposes, determined the botanical position of the tree and deseribed several speeies of cinchona, one of which is known by his name. 'To him is dne the generic title bestowed in acknowledgment of the services rendered by the comntess, who introduced the bark into kinrope. Many vain attempts were made to determine the chemical composition of the powder, and it remained for two French chemists to isolate and separate its most important alkaloid. The first who wrote upon the therapy of cinchona was Barba, a Spanish physician, whose work was printed in Seville in 1642. After its introduction into England Perurian bark fell into disrepute, owing to improper administration, whereby death was caused in certain instances; and it was this latter fact that instigated Sydenham to investigate it still more accurately. There has never been introdneed into medicine any one drug which has proved itself so generally valuable and so widely effective as cinchona and its products.

As little progress had been made in obstetrics as in other branches of applied medicine or surgery. 'The custom of employing midwires was general, and these, for the most part, were ignorant and filthy old women, slaves of rontine procedures that had obtained from time immemorial. Educated accoucheurs were called only in extraordinary cases; but with progress the prejudice which excluded educated physicians from the practice of midwifery gradu- 
ally gave way, and there was opened for obstetries a new era. In the begimning of the seventeenth century the initiative wats talien hy lonise Hourgeois, the sage femme of Marie de Medicis. who in 1626 published a collection of observations concerning sterility, abortion, fecmndity, acconchement, and diseases of women and children generally; it embodied several distinctly new ideas. A little later (in $1668)$. Mamricean, of l'aris, chief accoucheur to the HôtelDien. published his treatise on diseases of preguancy and childbirth, which was translated into all the languages of Europe and became a powerful agent for good, not alone that it represented an adrance in knowledge, but it stimulated such rivals and successors as Deventer, Pen, Paul Portal, and Delamotte to further research. About this time the Chamberlains, an English family devoted to the practice of midwifery, invented an instrument to facilitate the extraction of the foctal head when arrested, and one of them went to Paris, and, failing of success there, went on to Holland, where he sold his secret to two Duteh practitioners, who kept it only too faithfully. In 1721, Palfyn, a surgeon of Ghent, while seeking to fathom the device of the Chambertains, conceiver a tire-tête (literally a headdrawer) composed of two steel spoons, and hastened to publish an accomt thereof, - a praiseworthy act, whereby he merits distinction as the inventor of the forceps. As modified by Smellie in England and Lerret in France, the obstetrical forceps ranks among the most useful discoveries of modern surgery, and, although not in common use until abont a century ago, it may be said that the invention has been the means of saving the lives of countless women and children.

Medical jurisprudence also seems to have had its begiming during this century. It had long been the prictice to summon pliysicians to court in order to enlighten the judiciary in questions demanding particular knowledge in plysics and medicine; indeed, the practice 
began under the first Christian emperors, and owes its origin to ecelesiastical anthority. Charlemagne contirmed in this regard what Justinian was perhaps the first to ordain. 'The tribunal of Châtelet, according to lienonard, appears to have been the first which comprehended the great utility of consultation with expert physicians; an edict of Philip le Bel, in 1311, qualified Master John Potard with the title "Sworn Surgeon of Chatelet"; and the constitution promulgated by Charles $\mathrm{V}$, in 1552 , gare great importance to medical jurisprudence, as it treated in detail of infinticicle, womnds, poisons, abortion, and other such crimes. Farly in the seventeenth century Fidelis collated all that had been written on this subject, and thus published the first special treatise on legal medicine.

Some writers claim to have discorered traces of clinical teaching in the history of Arabian miversities, bnt, as Renouard says, the presence of a few pupils during visitations and consultations no more constituted real clinical teaching than the practice adopted by some practitioners of ancient Rome of being ever surrounded by a group of spectators whom they dignified with the title of disciples. The first attempt at real clinical teaching appears to have been in the hospital of St. Francis, in P'adna, in 1558, by Botoni and Oddi. About the begimning of the seventeenth century Otto de Henrne, of the University of Lerden, introduced bedside instrnction, which was continned by le Böe, sometimes called Sylvius, with the result of drawing large crowds of students to leyden from 1658 to 1672 . Notwithstanding the success attained, the practice was neglected by the successors of Sylvius until renewed by Boerhaare, who, invested with several functions at the University of Leyden, also occupied the chair of medicine. So great was the renown of Boerlaave that, despite the porerty of the resources of the Leyden hospital, people came to consult him from the most distant countries, and he was a correspondent of several crowned heads, even of the Pope, 
although himself a Protestant. During his life and long afterward he exerted an immense influence in medicine, and while, perhaps, inferior in genius to some of his contemporaries, he had a wider reputation, and his doctrines prevailed longer. 'The great success of his clinics decided in faror of this method of teaching, and in 1715 the Pope established in liome a similar institution, under the direction of the celebrated Lancisi. Soon Edinburgh, Vienna, P'irvil, and other miversities followed suit, the first clinical fhair in Paris being held by Corvisart, and the first in Viema by Van Swieten. After the demise of Boerhave, the school of Leyden rapidly cleclined, while those of Edinburgh and Vienna became rivals for the first place. It is thus seen that after an intermption of more than two thousand vears clinical teaching was revired and became more brilliant than ever before.

I now propose to recount the methods and deeds of some of those concerned in the derelopment of systems, so called, and make mention of the most prominent medical men in mational and historical order. 'This will not prevent groing back to philosophieal conchusions or reflections upon the philosopliy of the history of medicine, when it may seem wise so to digress.

First, of the system of J. B. Van Helmont, which in its day was most highly regarded, and which seems to lave been, in some measure, a rearangement of the riews of Paracelsus into a mystic and pietistic system based upon mechanical principles. Van Helmont was born in Brussels in 15\%8, and was so precocious that he entered the Unirersity of Jourain at an age which would have enabled him, had lie so desired, to obtain the degree of Magister when only seventeen years old. IIe deemed the degree frivolous. IIe had studied mathematics, astronomy, philosophy, and astrology. Going now to the Jesuits, who at that time, even, taught music, he soon became dissatisfied, and turned to the study of stoical philosophy. Believing 
that the Capuchins (who were mere lascivious gluthons, and considered even washing unchristian) were the true: stoics, he sought to join this order, but are lomgatandomed them and resumed his studies in law, botany, and medicine. For the latter Vian II elmont had at first little respeet, since his studies in this line did not enable him to rid himself of the itch. He soon again linpsed to the monastios, and came to the conclusion that wistom, like the grace of God, was obtainable only by fasting, supplication, and poverty; accordingly he practiced medicine among the poor as a labor of love (having reeenved his degree of Doctor in 1599). During his travels he became fimilian with the writings of l'aracelsus, which he studied zealonsly. Finally he settled down in Vilrorde, where he practiced medicine and chemistry until his death (in 16+4).

Like most "systems," that of Vin Hclmont is valued only as an expression of the spirit of the age, since it (mbodied largely the pantheism of l'aracelsus, merely cloaked with a more religions or monkish dress. He held that the general canse of disease was the fall of man; though there also figured a sulssidiary eause, which he denominated Archens, - a faculty of appetite seated in the spleen or in the stomach; thus dropsy was a hindrance of renal excretion by the enraged Archens. Demons, witches, and ghosts were included in V'an Helmont's ș̣stem as canses of disease. Indeed, the man seems to have been a second Paracelsus, lacking only in the dishonesty and bombast of the latter. Ife had no followers of any prominence, and the "system" soon lapsed into obscurity.

'The Chemical, or Iatrochemical, System was originated by le Böe, commonly known as Sylvius (but who must not be confounded with the great anatomist of the same name). Le Böe was born in IJanan in 1614; studied in Paris, Leyden, and Basel; received his doctorate from the latter university at the age of twenty. and practiced in Switzerland with great success until 1660, when he 
accepted a professorship in leyden; here he was distingruished for his cloquence, wealth, and sociability, as well as for the graat number of pupils that were attracted by his clinical method of tcaching. His system embraced a peculial phantasy, being based upon the elements of chemintry, the new knowledge of the circulation, the latest phisiologinal toachings. and the old floctrine of the spiritnois or innate heat of the heart, which he claimed to have felt with his finger. He asserted his theories were founded upon expericuce, but the truth is, they were inaccurate deductions from experimental observations, many of which were wholly irrelevant. The majority of diseases, he taught, were prodnced by excess of acidity or alkalinity. For him, the three great fluids of the body were the saliva, the pancreatic fluid, and the bile, while health consisted in the undisturbed performance in the body of the process of fermentation; and the saliva was supposed to give rise to hertic fevers, because such manifest exacerbation after eating. Stereotyped theory and equally stercotyped therapenties ganed for him. for a short time, a large following, but latel raised mmerous opponents, who alleged that his system cost as many human lives as the whole thirty years' war. He died in 1672 .

'To the same jatrochemical school is generally assigned Thomas Millis. bom in Oxford in 1622 (died in 1675), who rendered grat serviec to anatomy, especially to anatomy of the nerrous system, although his teaching was disfigured by cortain unsupported theories. Like Van Helmont, he lual been destined for theology, but turned his attention to medicine. Ultimately he became Professor of Philosophy in the University of Oxford. IJe first described the socilled circle of Willis, whence its name; also ascribed diseases. especially those of the blood, to fermentation, in which the vital spirits played the chief part. He accounted for hysteria, for instance. by the mion of the spiritus with imperfectly purified blood. 


\section{CIIAP'TER VII.}

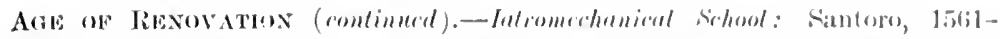

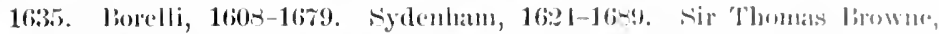

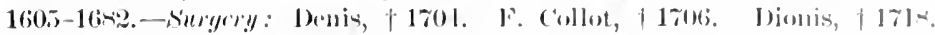

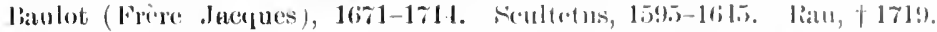

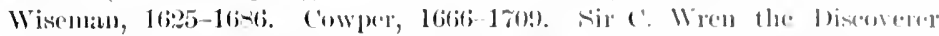

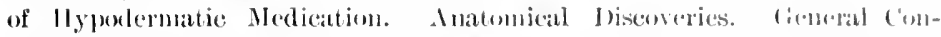

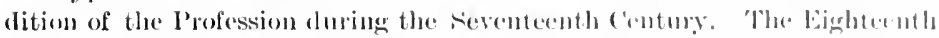

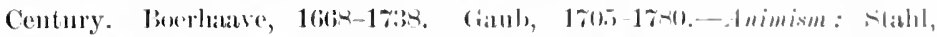

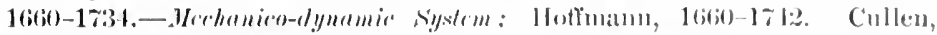

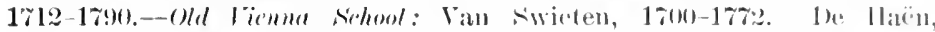
170.1-17\%6.-litulism: Borden, 1792-1796. Erasmus 1)arwin, 1731-1-0\%.

'Tue physiology of the Iatromathematical, or Iatromechanical, or Iatrophysical Sichool devoted chicf consideration to the solid parts of the economy, whose form and function it strove to discover and demonstrate by the aid of exact methods, - that is. ly calculation and physical apparatus. Thus, it explained digestion as mechanical trituration; secretions were referred to variation in resistance of parts in the vascular system; warmth was supposed to be due to friction of the blood-corpuseles; health consisted in the undisturbed performance of the physical and mechanical processes of the body. Diseases were explanined inversely: the blood, under diseased conditions, was held to contain pointed and angular crystals, which irritated as they passed through the pores, or disturbed because they could not so pass.

The first to ennuciate these views was Santoro, or Sanctorins, who flourished from 1561 to 1635 , and was for a while professor at Padui. He tanght how to investigate the pulse by an instrument of his own contrivance, and how to study the temperature by means of a species of thermometer, which was probably his own invention. ('This instrument, ly the way, was invented about this time; Drebbel [1572-1634] is regarded as the inventor of the air-thermometer, Galileo [15it-164\%] of 
the spirit-thermometer, and lioemer [16t4-1710] of the mereurial thermometer.) Santoro studied the phenomenon of transpiration, and constructed apparatus for bathing bed-ridden individuals; he found that in twenty-four hours the insensible transpiration through the slin amounted to l. kilogrammes, - which result, compared with the results of the present day, deternined by the most complete observations, is only twenty per cent. too high, and proves how accurately he investigated. The important rôle of the perspination, which he pointed out, was made use of by the iatrochemists to vindicate their terrific sweat-cures.

Borelli (1608-1679), of Naples, is usually regarded, however, as the founder of the iatromechanical school. Of a quarrelsome disposition, he conld not stay long in any one place, though he ultimately settled in Rome, where he joined the circle of suvants who gathered round Christina, the daughter of Gustarus Adolphus, who had become a convert to Catholicism. Finally Borelli entered a monastery. His services related mainly to physiology, where, like Descartes, he followed purely mathematical principles; he explained the action of the nuscles by the laws of the lever, calculated the mechanical work done by the heart, and correctly ascribed inspiration to muscular action. He was the opponent of iatrochemistry, and claimed there was no such thing as corruption of the blood. His pupils and followers-like Bellini (16 $43-1$ i04), of Florence, who became professor in Pisa at the early age of nineteen, and Baglivi (1668-1707), a pupil of Malpighi, and a man of universal education-carried out and elaborated the first expressions of this anthor. Borelli was the author of the oft-quoted maxim: "He who diagnoses well cures well."

The iatromathematical system held ground for some time in Italy, and also found followers elsewhere. For instance. I)odart (1664-1707). of Paris, explained the voice on the mechanical principles enunciated by Borelli 
and by Quesuay (1694-1774), the first permancut secretary of the Academy of Surgery in l'aris. In lingland this explanation was atopted by a number of followers, none of whom, however, was eminent enongh to justify spercial mention here. In Germany it obtained a certain amonnt of firvor, but seems not to have attracted any very emincent disciples.

The iatromechanical school wan a comse not mupofitable to science, yet was unfuitlul of real advance in the

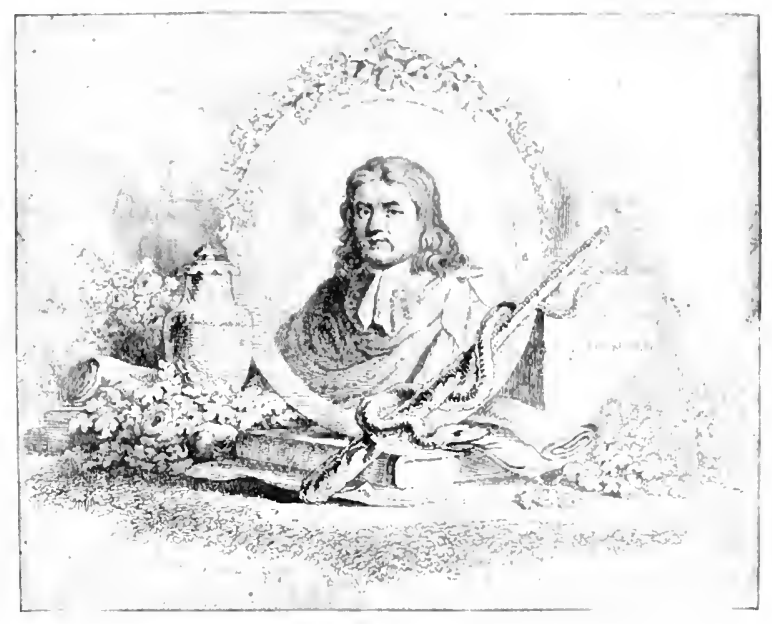

Fig. 23.-THOMAS SYDExHAM.

(From a steel engraving of a prainting by II. F. Rose.)

domain of practical medicine. The man of this particular age, who, more than any other, exerted an influence destined to be prolonged even to the present time, and probably much longer, who had a cool, clear, and mprejudiced spirit, and who sought the true value of medicine, and recompense for the same in the benefits which it brings to the sick, withont scoming or neglecting its scientific side, was Thomas Sydenham, bom at Winford Eagle in 1624, a student at Oxford in 1642, and recipient of a bachelor's degree of medicine in 1648 . 
The next fifteen years of his life we know practically nothing of, sare that he spent some time in Montpellier pursuing his medieal studies. In 1663 he became a member of the lioyal College of Physicians, but did not take his degree of Doctor until 1676 , - thirteen years before his death. His chief work-Medical Observations-is said to have been originally written in English, and translated into latin; it first appeared in 1666,- the year when fire and plagne devastated London. He died of gout in 1689, and was buried in Westminster Abbey. Inring the earliest years of the plague in London he fled, as was the general custom of that day.

Ifis model was Hippocrates. In pathology he was a humoralist without being a theorist. He knew only one standard,-observation and experience. Sharing the opinions of his disy, he laid but little weight upon anatomy and physiology; yet he recognized their value when employed in the production of hypotheses. He conceived of disease as active, operative, - a natural effort of the body to remove morbid material from the blood; if this eftort is riolent and speedy, we have to do, he says, with an acute disease, but if slow and difficult, the condition is chronic. Fever was supposed to result mostly from cold or from epidemie influences. As causes of disease, he considered unknown influences and changes of the atmosphere very important. In his special pathology "inflammation of the blood" played the chief rôle, and upon it were made to depend nearly all acute and some chronic diseases. He arrived at what he called the "healing power of Nature," for which he made great chaims in his description and observation of epidemics: but he believed there always remained a good deal for the phrsician to do, and in treating syphilis he even gave mercury until two kilogrammes of saliva were discharged daily. As compared with the therapentics of that day his were manifestly simple,- and yet he employed, for 
example, eighteen different herbs in one prescription, and that merely an ointment. 'The unreliability of the action of drugs induced him to rely upon specifies, ats did Paracelsus, but he acknowledged only one such,- the then new discovery, cinchona,- not even allowing mercury such a position in the treatment of syphilis. Such drugs as he chose were mainly from the regetable lingdom.

'The great importance of Sydenham, and all his statements, so far as we are concerned, centres about lits strugghle for the elucidation of the healing power of Nature, and for simple observation and simpler trealment, as opposed to the overgrown luxuriance of previous systems and theories. He became the standard-bearer of his age in his retum to Mippocrates's method and art of healing, which are founded on the nature of things and on the limits of human ability.

Sydenham was vehemently opposed by Richard Morton (1625-1648), of London, whio, like Fernel, considered all diseases to be a poisoning of the vital spirits. Syclenluam was also antagonized by Gideon Hanrey, who ridiculed his medical contemporaries without stint, becanse most of them, for febrile disease, gare catharties from the second day, and began treatment with emetics. With delightful satire Harrey divided the physicians of the day into six elasses: the Ferrea, Asinaria, Jesuitica. Aquaria, Lamiaria, and Stercoraria, according as their favorite systems of treatment were the administration of iron, asses' milk, cinchona, mineral water. venesection, or purgatives.

Sir Thomas Browne (1605-1682). who still cujoys a great reputation, was the author of the works entitled Religio Medici and Inquiries into Tulgar and Common Errors. The latter appeared in 1646 , but does not seem to have protected its author from the worst error of his age,-viz., superstition,- -since. in 1664, he swore that two condemned old women were actual witches. 
Ilaring considered the progress of medicine during the seventernth century, it may be well to glance likewise at surgical progress. Among the Italians Sinntoro, already spoken of ats the inventor of various instruments, should be mentioned; also Valsalva, who obtained a sound reputation as an operator, employed the ligature, and recommended a starration plan for treating aneurism; Magati ( $1579-1647$ ), who contended against the abuses of treating womuls by filling them with plasters. balsam, poultices, tents, etc., and of changing the dressing sereral times a day,-once in foul days was better, he said; Severino (1580-1656), first a lawer, then a professor at Naples, and latel an cminent surgeon, a good anatomist, and a particular friend of the actual cantery; Marchetti (15891673), a bold. versatile operator of Padua; and Borri, of Mulan (1625-1695), skilled as an operator and an oculist but better linown because of his sad fate, since he died in the prison of the Inquisition, after a prison-life of twenty-five years, on acconnt of too liberal religious views. There were also numerous other Italian surgeons who made a name, especially in plastic surgery, and particularly in that branch of it named rhinoplasty, by whose efforts one method of manufacturing a new nose came to be known as the "Italian method."

Fince, we must remember, was the lome, during this century, of Richelieu, Mazuriu, Louis XIV, Comeille, Rarine, Molière, Fénelon, la Fontaine, Boilean, Bossnet, and many other men eminent in literature and science. During this century the French laid the foundation for that leadership in surgery which they maintained for nearly two centuries. I et us mention, among their surgeons, Morel, who invented the tomrniquet at the siege of Besancon, in the year 1674. There was also Jean Baptiste Denis (who died in 1704), physicinn to Lonis XIV, who performed the first transfusion of blood in man.

('Transfusion of the blood of the young into the reins of the old, for the purposes of 
rejuvenation, was recommended by hibavius, in 1715 , and Colle, of Padua, gave it new support by describing a method for its performance. In 1729) Boyle practiced transfusion on dogrs. 'I'he London finculty sought the value of the operation after excessive himorrhage, and Edmund King, physician to Charles II, in 1665 practiced transfusion from vein to vein. But Denis was the first to carry out the operation with lamb's blood upon a patient sinking under excessive venesection, -an operation which was very much abused at this time.) It was in this century that the French family of lithotomists-the Collotsdistinguished themselves in their special line. The last member of the family, François, died in 1706. Their specialty must have found, at that time, considerable more material than comes to the front to-day.

Among the general surgeons of France were de Marque (1618), who distingnished himself as a bandager; Bienaise, who invented the bistoury caché (1601-1631); de Lamay (1649), monk and lithotomist; Goursaud, who survived his century, and who was the first to describe stercoral incarceration; Duverney, who demonstrated the growth and nutrition of the bones by periosteum; Lambert, who practiced injections in hydrocele; Andry, of Lyons, who wrote of orthopadic surgery and originated the name ortlopedics; Pierre Dionis (who died in 1718), surgeon to the Empress Maria Theresa, famons in his art, and who first emphasized the effects of rickets upon the pelvis; and Boulot, better known as Beaulicu (1671-1714), who actvanced himself from being a soldier and a day-laborer to become a physician, a fumous lithotomist, and surgeon. He finally joined the Franciscan order, where he obtained the name of Frère Jacques, under which title he passed for the inventor of lateral lithotomy. Then there were Saviard (1656-1702), surgeon-in-chief in the Hôtel-Dieu, who, among other things, determined the seat of hernial strangulation to be often in the neck of the sac; and 
Georges Marreschal (1658-1736), surgeon to Louis XIV, one of the founders of the Academy of Surgery, who has a record of eight lithotomies performed in half an hour, and who becime fimous for his services in improving the schools of surgery in France.

In this (the seventecnth) century, also, ophthalmology was much cultivated in France, although it was assigned to the despised surgeons. Those who won most renown in this line were Maitre Jean and Brisseau, who divide the honor of first recognizing the seat of true cataract. During this period, also, Duverney, Professor of Anatomy at Paris, was the first to systematically describe diseases of the ear in accorlance with their anatomical seat.

In Spain scholarship sank more rapidly during this century than among any other people in history, due mainly to the loss of their political supremacy and their commerce to the Dutch and English, and to the utter failure, at home, of their efforts to introduce true unity of faith. In these efforts the industrious Moors were excluded, under Philip III. In art they maintained their standing,-attaining, in fact, in Murillo, the acme of their fame; but in other branches of industry they rapidly degenerated. Students of history will readily understand how little leisure the Spaniards had at this time to derote to the cultivation of science, including medicine and surgery. Of the two men who are mentioned during this century as Spanish surgeons, namely, Almeida and Ayala, we know practically nothing.

The Germans gained no such store of knowledge from their experience during the Thirty Years' War as did the French during their campaigns. The barber-surgeons, for the most part, still reigned supreme, and their guild contained some men of ability and independence of thought. 'The most notable man of the times was Fabricius Hildanus $(1560-1634)$. Of him, howerer, I have already spoken as belonging rather to the previous century. He was the first 


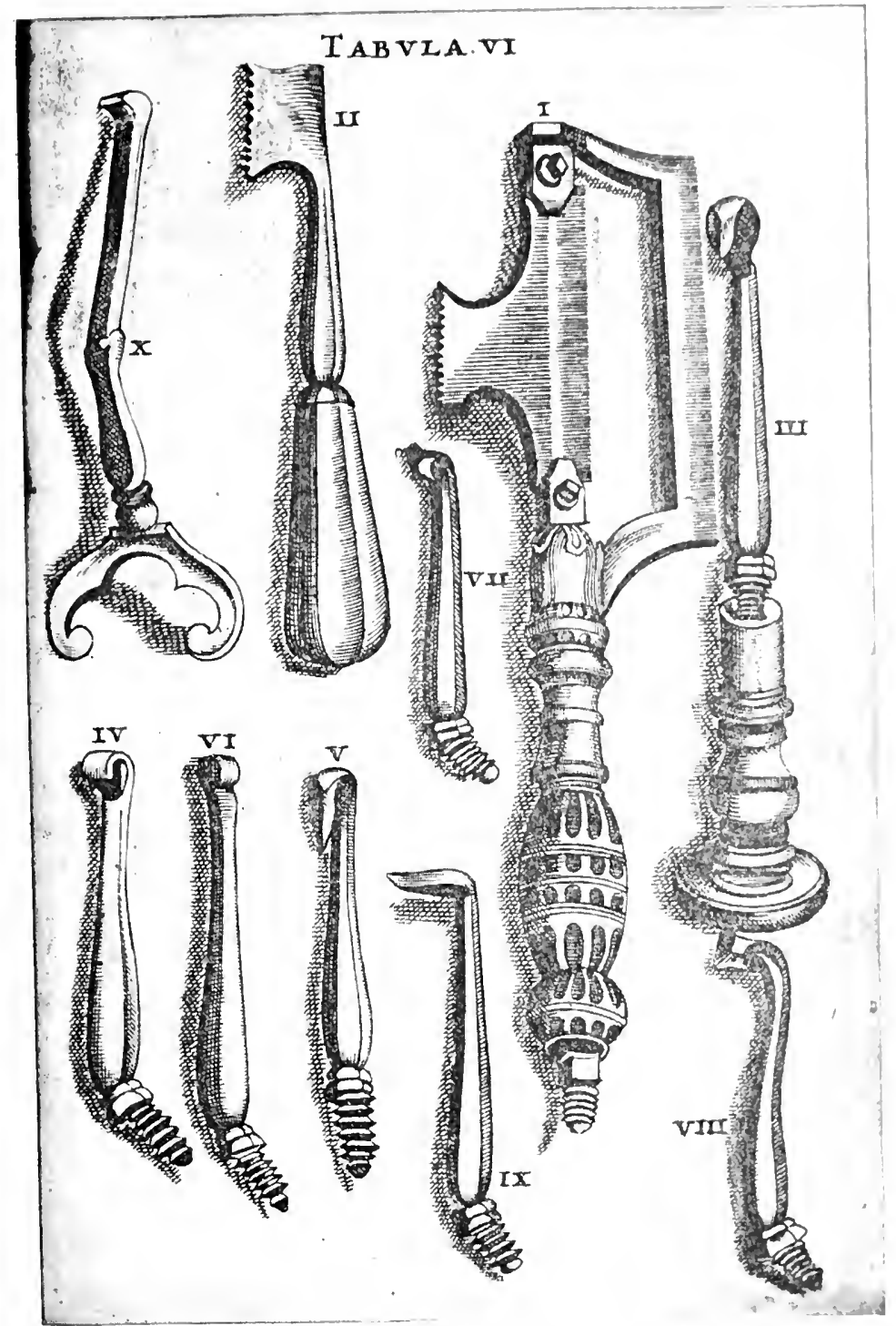

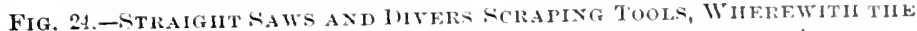
SKULL, BEING ROTTEN OR HAVIXG A FISSLIE, IS FCRAPED IWAY.

$I$ and $I I$. straight saws. $I I I$ to $X$, varions forms of seraping tools.

(From The Chyrurgeon's Sture-hentse, by Juhannes sentetus, a famnus physician and surgeon of

Ulme in Suevia. English translation published in Londn in $16 i_{1}$.) 
learned German surgeon recognized and esteemed as such by his contemporaries. ILe was distinguished, also, as an oculist and amrist, and remored a particle of iron from the cormea by means of a magnet. A man of great operative genius, and a born surgeon, was Purmann (1648-1721), who greatly lamented the low condition of surgery in Germanr, and regarled a knowledge of anatomy as the prime requisite for the surgeon; he employed the speculum in the diannosis of syphilis, although it has been Ricord's boast that this was his own iclea. Scultetus (1595-1645), of Tlm. was a famous surgical writer of this period, and a bundige of his derising is still in frequent use, and bears lis name. Muralt, of Zürich, was also a capable surgeon $(165 \%-17335)$.

The butch had but few men during this century who enjoyed any reputation as surgeons. The best among them was Rau (1658-1 719), who, from being a poor boy, became a barber, traveled extensively, and was finally made Professor of Anatomy and Surgery in Leyden, where he introduced the innovition of teaching practical surgery upon the cadaver. He was especially famous as a lithotomist alter the method of Frère Jacques, although he did not give instruction on this subject in his lectures.

13y the way. it is an interesting fact that the clinical listories of many operations for stone during the seventeenth century were related in verse, and illustrated with plates. Harvey's riviscctions were also related in verse.

Now, for the first time, do we begin to hear of English surgeons and English surgery. The most prominent, as well as almost the earliest, was Richard Wiseunin (159j-1686), ordinary surgeon of James I, called somotimes the "Pride of England" and sometimes the "l'aré of England,"-a bold, judicious operator, who took hold of every novelty and who accepted the ligature of Paré (always liaving the actual cautery at hand, in case the ligature slould firil); he also amputated through sound 


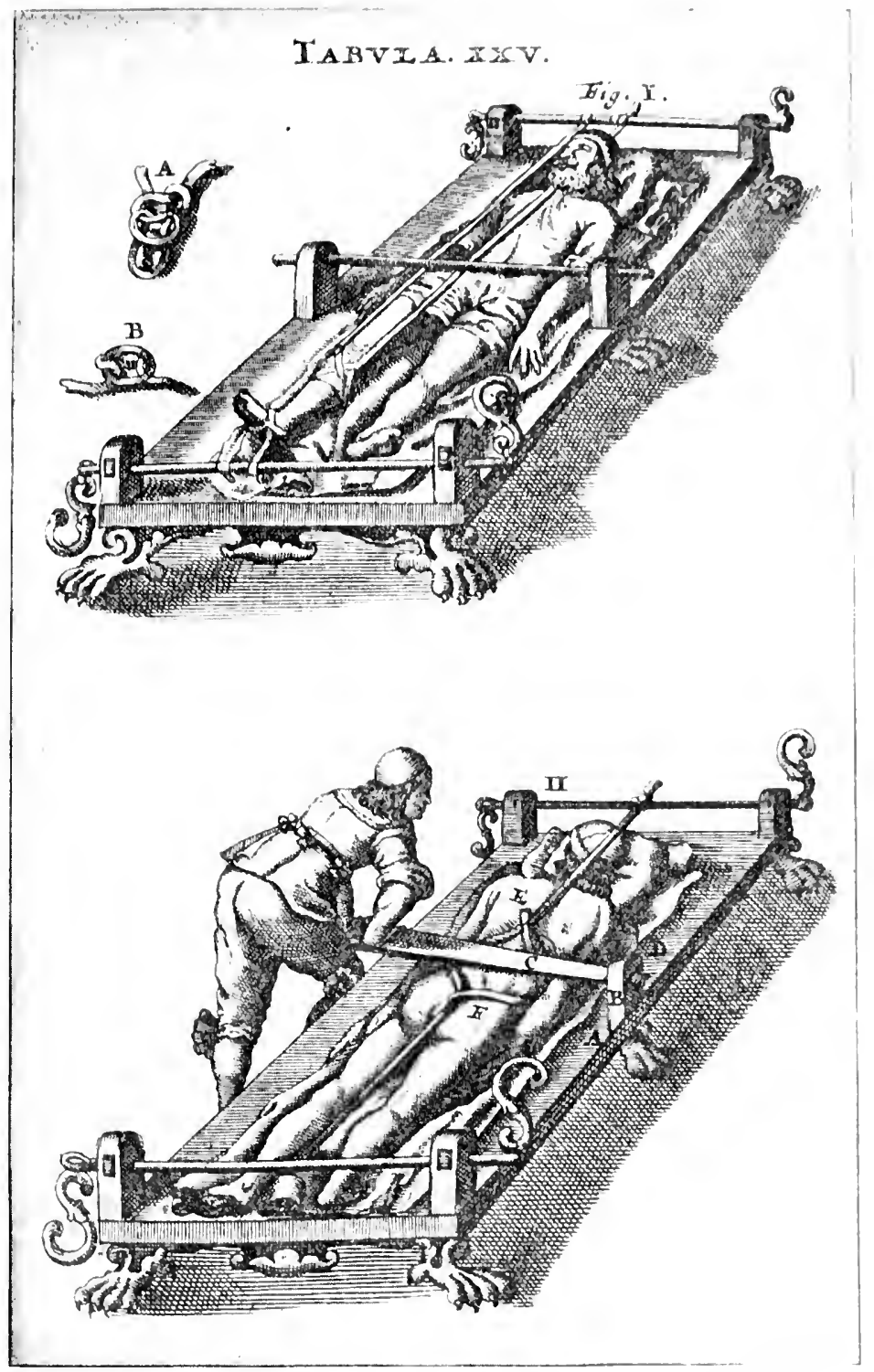

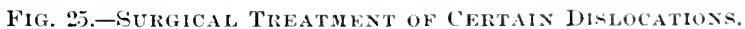

$I$ shows the reduction of the ankle-bone. $I I$ shows the extension and im. pulsion of the spina dorsi disloeated externally.

(From The Chyrurgeon's Store-house, by Johannes Scultetus, 1674.) 
parts, farored operating for strangulated hernia, and employed the trephine zallously. The first recorded operation for external urethrotomy for the relief of stricture is mentioned in Wiseman's witings.

'There were also William Cowper (1666-1709), a famous anatomist and surgeon ; and Woolhouse, a famous, but ignorant, itinerant oculist. Sir Christopher Wren, arelnitect of St. Paul's, was the first who devoted attention to injecting medicine into the reins, - a subject studied agrin much later and recently once more taken up. His example (in 1667) was followed by others, whose experiments demonstrated, as we know to-day, that the effects which follow the intravenous administration of drugs are the same as follow administration by the mouth.

Midwifery during the serenteenth century adranced even more rapidly than its mother-science surgery. The accouchement of women was intrusted in many cases to the care of educated men, who contributed not a little to the art. Anatomy and physiology contributed also their quota to a clearer knowledge of these diseases. The obstetric forceps were for so long a time liept secret that they were of small benefit at first to the obstetric art. Among the French who were especially prominent as promoters of midwifery must be mentioned Marguerite de la Marche, chief midwife of the Hotel-Dieu; François Mauriceau, President of the Collegre of St. Côme; Jules Clement Delamotte, who was also a skilliul surgeon; and Portal, who first proposed version by one foot. Among the Germans a few midwives distinguished themselves as independent observers, most of all Justine Siegemundin, daughter of a minister, who deroted herself to midwifery with such success that she became court midwife; she recommended puncture of the membranes for the production of artificial delivery, and especially adrocated bimannal version.

But, perhaps, the most significant advances were made in the direction of studies in anatomy, physiology, and 
pathology. The history of the circulation we have alrealy taken up. After Harvey's time, and largely because of his researches, physiologists were divided into two parties with regard to the origin of life. These parties were known ats animists and animalculists. It wats largely by the later researches of Highmore (1613-1685) upon the anatomy of the testis and the epididymis, supplemented by those of Aubrey in Florence concerning the ovaries (which had been previonsly considered as female testicles), and the researches of Stenon concening the muscular nature of the uterus, that a better knowledge of reprodnction was established. De Graaf (16+1-1673), a plyysician of I) lit, IIolland, pointed out the ovarian follicles, known to-day under his name, while Swammerdam (1637-1686) studied the comparative anatomy of the ovaries, -and was, by the way, the first to prove that the queen bee is a female. Needham, the London anatomist and physician, and Hoboken, of Utrecht, described more accurately the phacentil and the coverings of the orum.

Anatomical discoveries crowded along about this time. For instance, Wharton (1610-1673) discorered the submaxillary duct, named after lim; Glisson (1647-1671) studied the liver and recogrnized its capsule, that still bears his name; Nuck injected the lymphatics with quieksilver, and studied the glands especially; Stenson diseovered the excretory duct of the parotid, and Rivinius (his name being translated in German, Bachmann) found the sublingnal duet; Peyer, Schafhausen, and Brmmer, the latter a professor in Heidelberg, discovered the intestinal glands which bear their names; Wirsung, of Bavaria (who was assassinated in 1643 by another physician), discorered in the dissecting-room of Vesalius, at Padua, the excretory duct of the pancreas; Pacchioni found the bodies named after him in the dura mater; Havers, of London, discovered the synovial glands and the so-called IIaversian canals; Cowper, already mentioned, discovered the small glands named 
after him, located in firont of the prostate, and Bartholin yet other glands, in the labia, which bear his name; Meibom, professor in Helmstidt, discovered the small glands in the eyclids which are named after lim. Besides these, many other discoveries might be recorded here, did time permit. One other, however, deserves to be mentioned, with which the name of Schmeider (1614-1680) must always be honorably connected. He described the mucous membrane of the nose and demonstrated anatomically and clinically that not the brain, but this membrane, secretes the mucons discharge during fluxes from the nose. This overthrew at once and forever the ancient doctrine, which included so many and various "catarrhal" diseases. I might add also that the best and most complete description

Description of Fiy. $2 \%$ - Of the corruption of the bones of the arn and shin, eren as far as the marow; oi the shin-bone broken with a wound and the bones sticking out aml bouml with swathe-bands brought circularly about; and of the cutting off of the enl of the hand or foot. I represents the corruption of the bone and of the marrow of the shin-bone. II represents the shin-bone wholly corrupted and rotten. III represents the place where the corrupt bone was situated and was now pulled forth with the pincers. Fis that shin-bone corrupted, which the patient laid up for a memorial. $\quad V I$ is the bone of the right arm corrupted. FII represents the bone of the arm totally corrupted and sharp, which was pulled away with the pullers, but by pieces, without any noise or pain. VIII shows the place where the corrupt bone of the arm lay, which was now pulled forth, which Nature filled up with a callous, so that the patient could perform country business without any imperliment. The patient was a comtryman of Pappatavia, whose arm a souldier broke in four places, without any wound, anno 1636 . $I X$ is a fracture of the shin-bue with a womd, and laying the bone nakel. $X$ is the bone of the shin with a womd, broken, with hones stieking forth, and bound with bands not crosswise, but circularly brought about ancl haid within the capsula as it ought to be. $X I$ is a hamd atlected with a secret cauker which is cut ofl in the somul part, namely at the cml of the ralius and cubit bone. XII is a hand that is sphacelated, which, being laik upon the block $(D)$, is amputated in the sound ends of the radius and arm-bone with a chizel $(E)$, contrary to Hildanus, with good suceess. XIII is a basin filed with oxyerat, in whieh swims a bladder, which, being wet, must be applied to the mutilatel part. XIV are two swathe-bands wrapt together ( $F$ and $G$ ), wherenf each hath two culs, to bind the arm, whereof the hand at the end is cut off. XV represents a font that is sphacelated, which is taken off in the mortifiel part, near the souml part with a pair of pincers. The mortified part being removel, the rest of the putrefaction is consumed with red-hot irons until the patient feels the force of the lire. After this two plagets are anointed with Hildanus, his unguent Egyptiac, which are applied to the escar; lastly, long plaisters $(I)$ lieing laid unn st, the foot mutilatel is bound with a wet banil $(K)$ as far as the knee, as the hand is unto thr mlidle of the arm. XVI are divers sorts of iron instruments and nate reil hot, both to ennsume the remainder of the putrefied part and are also fit to stop the flux of blood." 


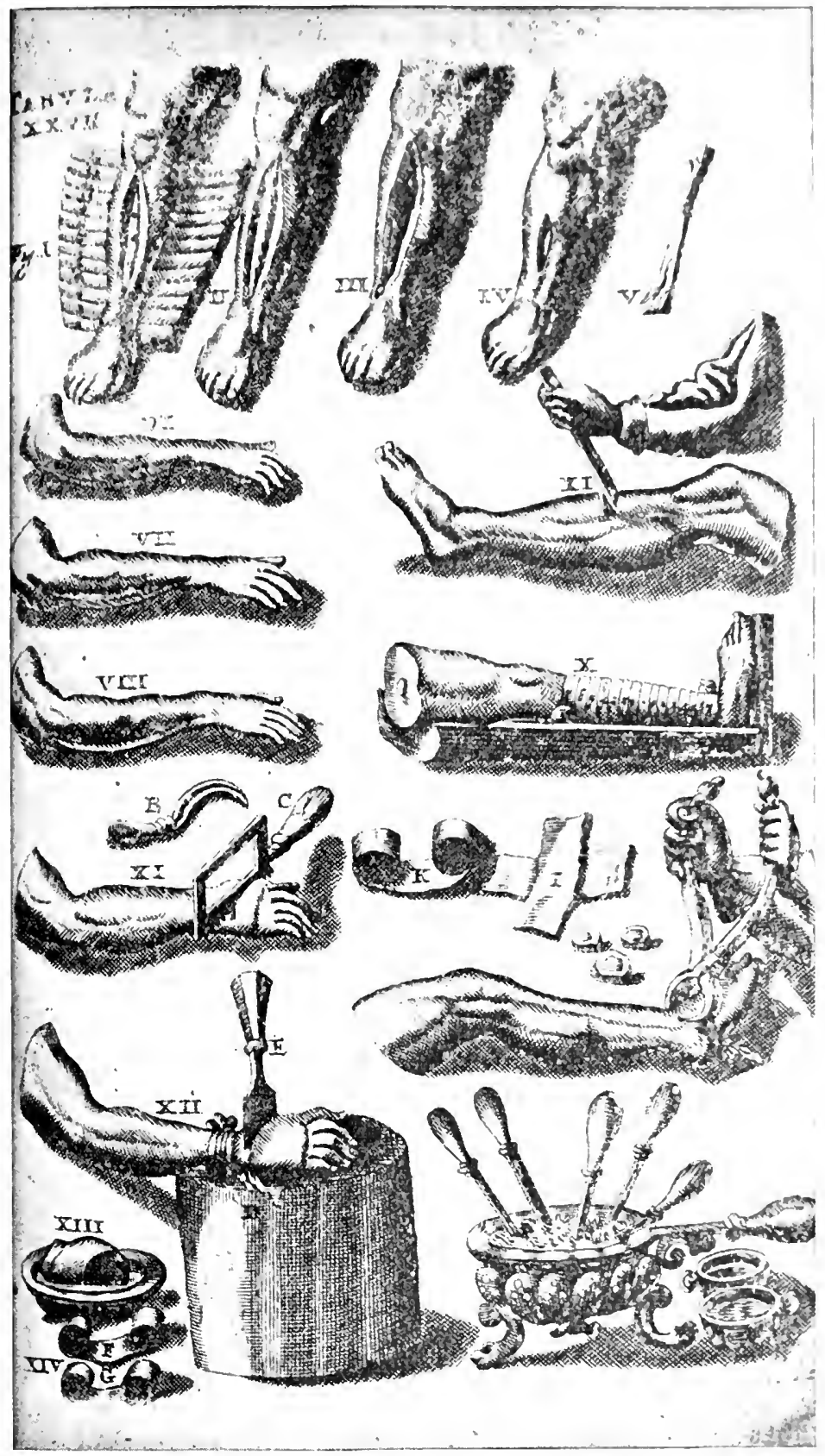

Fig. 26.-VARIOUS OPERATIONS ON THE ARIS AND LOWER LIMHA.

(From The Chyrurgeon's Store-house. by Johannes Scultetus, litit.) 
of the entire central nervous srstem which had been given up to this time was furnished by Vieussens.

By the middle and latter portions of the seventeenth ccutury most of the better physicians and surgeons had either assumed offices and positions in which they were supported by the State. or were settled in permanent residences, which was not the case with the mass of physicians in the sixtcenth century. As a result the reputation of the entire profession began to improve, while the unlimited license and absolute freedom of practice prevailing during the Middle Agres were almost entirely done away with. By this time the clerical element had disappeared almost entirely from medical circles, or only dabbled in certain specialties. The 'Thirty Years' War was fatal to the supremacy of the clergy in matters of public health. Moreover, the increase of international intercourse favored the communication of medical knowledge.

The phrsicians of this period were more occupied with ehemistry and physics than had ever been the case before. Nevertheless, this was also the special age of alchemists and of impecuniosity. According to one of the classifications of the time, the regular profession was supposed to include physicians, surgeons, barbers, regimental surgeons, lithotomists, bath-keepers, midwires, nurses, apothecaries, druggists, and even confectioners and grocers. Another list of impostors and quacks, equally official, was male to include old women, village priests, hermits, quacks,

Jescrimk of Fig. 2r.- I represcnts the breast affeeted with an ulcerated canker, the basis whereof is thrust through with two needles drawing after them a twintell flaxen threal. II shews bow the elyyrurgeon takes hold witl his left hand, of the colds of the threads that were thrust throngh, and with his right hand he takes the knif. and with that he cutteth the anker out by the roots. III shews a canker cut from the breast weighing six physlcal pounds. IF shews how the ehyrureseon, after the cutting ofl of a breast ulcerated, doth lightly cauterize the place wilh a rell-hot iron at least to corrohorate the parts. $V$ is the instrument of Hierom Fithitius alo Aquapentonte wherewith a fistula of the thorax is perforated. $V I$ is sostratus, his banl. which is most convenient where the breast is affected with any disease that requires hinding. FII shews how Celsus cured the sticking forth of the navil hy manual operation. VIII is a truss for the navil made of a double cotton linne'u cloth." 
uroscopists, Paracelsists, Jews, calf-doctors, executionrers, crystallomancers (a class of people-chiefly Italian-who sought after crystals), mountebanks, vagrants, magicians,

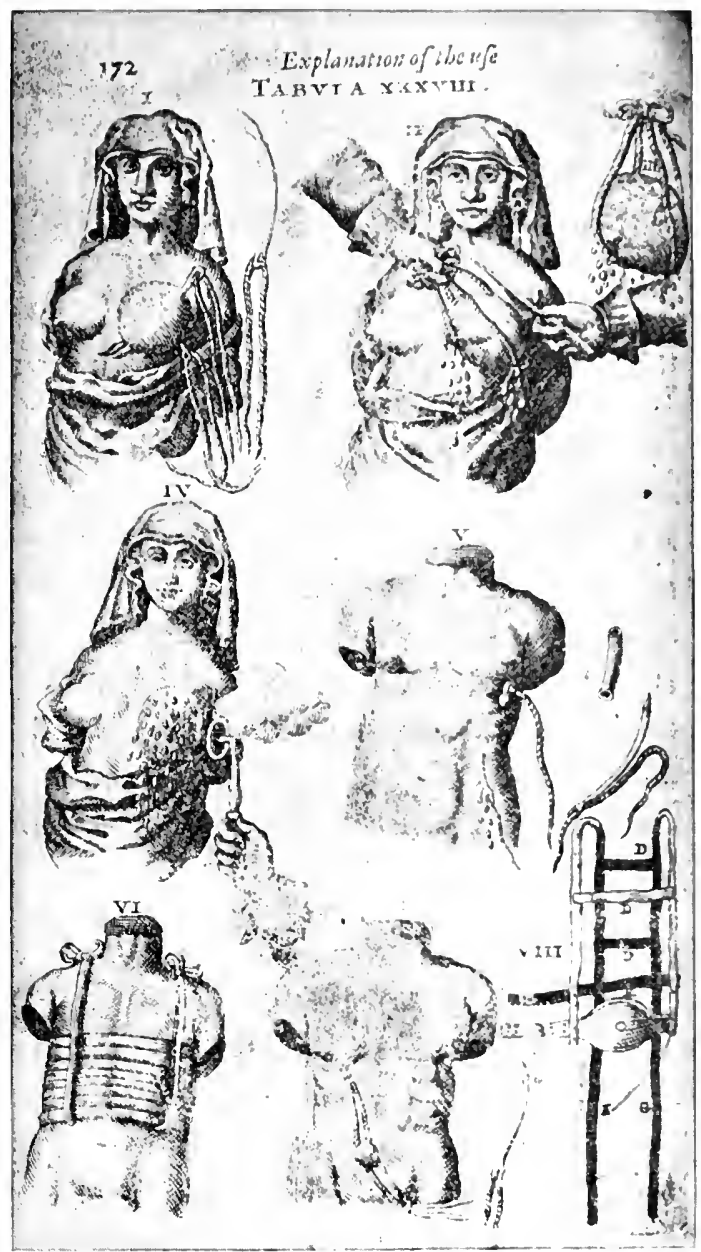

FIg. 27.-SURGICAL OPERATIONS ON TIFE HEEASt, ETC.

(From The Chyrurgeon's store-house, by Johannes scultetus, 1674.)

exorcists, monsters, rat-catchers, juggglers, and grpsies Veterinary physicians were also at that time included in this class. 
Anatomy was now studied more from human bodies, and was anthorized by statute. 'This was especially the case in non-German institutions, to which for this reason students Hocked in great numbers. In Dresden, so early as 1617 , there was a dissecting-room in which stuffed birds, at that time a great rarity, and similar curiosities were preserved. 'The study of anatomy was at a low ebb in Germany; so that when Rolfink, in 1629, arranged at Jona, which was then the most popular German university, for two public dissections upon executed malefactors, it was considered such an event that the very highest anthorities were present. But the peasantry took such fright at this oceurence that for a long time afterward they watched their cemeteries by night lest the corpses should be dug up and, as they said, "Rolfinked." Vienna did not possess a skeleton until 1658. Strassburg obtained one of a male in 1671 , and several years later one of a female. In Edinburch an anatomical theatre was first erected in 1697 in Surgeons' Hall. It is worthy of remark that anatomical plates, designed to be lifted off in layers, existed even at this period. About the middle of this centmry there arose a dispute at the bedside of the Margrave of Baden, between two learned professors and the regular court physician, whether a plaster to be applied over the patient's heart should be placed in the middle of the chest, according to Galen, or upon the left side. The dispute was settled by opening, before the eyes of the noble patient, a hog, by means of which it was demonstrated that, as a matter of fict, the heart of the hog lay on the left side. So convinced was his excellency that he dismissed the ordinary physician, who had held a contrary opinion as to the position of a nobleman's heart.

'The general barbarity and immorality of this century were conspicuous, especially among the upper classes, and by its close had spread from France, became naturalized in both Germany and Italy, and extended even to the 
universities, their professors, and their students. 'The life of the latter during this period was more vulgar and rude than ever before, and almost more so than ever since. l'ennilism-that is to say, barbarity towarel jumiol students-became umbonnded, so that ontbreaks occurred even during lectures. At last the State anthorities were compellerl to interfere. Student outrages were very frequent and often fatal, and their outbursts were disgraceful in the extreme.

Only in France was instruction in surgery well regulated, for this was the only country which possesied a proper surgical college. Practical instruction was imparterl to midwives-in Paris throngh a special institntion, in Germany through the Midwives' Guild; the barbers, too, continued to receive instruction from their gruilds; while instruction in pharmacy was given by the master-apothecaries, too often dogmatically and even farcically, serving as objects for the keen satire of Moliere. The expeuses of graduation were very great, and the ceremonies sometimes lasted two days.

In another way this same seventrenth century might be characterized as one of aggrandizement for physicians, -that is, as one during which their position was improved in the eyes of the public and better supported by the State. The physicians proper-the "medici pur $i$ "-were still persons of the profoundest gravity, with fur-trained robes, perukes, canes, and swords, when matters were prosperous, who for their lives would do nothing more than write prescriptions in formal style, everything else being considered beneath their dignity,-even as they affect in England to-day. They demanded to be called in every case, however, even though they knew nothing about it, claiming that only by means of their presence could things certainly go right. Nevertheless, in dangerous cases-for example, during the plagne-they left the surgeons alone, while they looked upon the sick through the windows. In spite of this, however, they were generally esteemed and 
often sought for, as well in public as in private. Some of them were supplied with large libraries by their patrons or through their positions under the government, and most of them enjoged moderate prosperity. Their pay was, for the most part, recrulated in accordance with a definite tariff, while the State gradually cut down the doctor's honorarium to the pay of a day-laborer. 1)uring that century a certin plysician to a comntess in Munich recerred $\$ 25$ as his ammual stipend. For being present at a post-mortem and rendering an opinion thereon, each physician receired \$1.75. Surgeons who were zealous and eagrer were always highly esteemed; they were often better elucated, in many respects, because of their extensive trarels; but the social emancipation of the surgeons was not completed until the eighteenth century. About this time amputation of the arm was supposed to be worth 31 marlis (\$7.75); of the leg, 41 marks; or, if a patient died, half this price. Lithotomy cost 51 marks, or half of that if the patient died. For cataract operation on one eye the surgeon received 17 marks; for a like operation on both eyes, 25 marlis.

We find in medicine, as in other branches of knowledge, that each succeeding century presents its added quota of imperishable facts, making it still more important than its predecessor. We may say that the fifteenth century had prepared the way for a reforming idealism which was the principal characteristic of the sixteenth; and that in the seventeenth contury the realistic reaction against this same idealism showed itself in the church and the State by struggles against constituted authority, and in medieal science by the domination of inductive philosophy. 'The idealism of the eighteenth century was not reformative and humanistic. but revolutionary and humanitarian. The unsettled claracter of the century's events may be charged, in some degree, to the American and French revolutions, with their interpretation (and their attempted attainment) 
of the so-called "rights of man." 'The matsses were now supposed to be released, and philosophers created new doctrines, which had a greater influcnce upon the limes than ever had philosophical doctrines before. Ronsscan, for instance, aroused a revolution in politics and education, while skepties and materialists alike strove for general enlightenment, which was sadly needed. Among the higher classes extravagance and immorality prevailed extensively, among the lower classes poverty and ignorance. In Germany the rulers even sold their snljects, as when Hesse-Cassel sold to the Euglish seventeen hundred mejeenary soldiers, and other States sold smaller numbers. A criminal code, published in 1769 , contained soventen copper-plate engravings, illustrating various mothods of torture. A physician was always present when torture was inflicted, to see that the victim's sufferings were not greater than he conld bear. This inhuman mode of eliciting testimony was last practiced in Europe in 1569, in the Swiss Canton of '/ug. Popular education was a myth, and the ehildren of bondmen were not permitted to learn. No wonder the French revolution was hailed with joy allong the Rhine, where it swept away at once and forever the petty rulers, abbots, and bishops, who were the "bloodsuckers" of the people. The numerous wars of the century had no great influence upon the derelopment of medicine, except in the direction of surgery.

The eighteenth century was revolutionary also in the introduction of freedom of religious thomght, so that cherical physicians disappeared entirely from the ranks, save a few who officiated as lithotomists, like Frère Côme, or as oculists, like Wrabetz, the latter of whom was even a professor in Pragne.

This was the century, too, of I,eibnitz and Kant. of Linnæus and Lavoisier, as well as of Bach, Haydn, Becthoven, and Goethe. During it the most conspicuous services in nearly all branches of learning were rendered by the 
Germans. instead of by the Italians and English, as during the preceding century. In fict, Germany was then at the zenith of her glory, and supplied an impulse for all other nations.

The influener of philosophy and the natural sciences became also more and more marked. At the head of its philosopher's must be placed leibnitz (1646-1716), who, by his own writings and those of his pupils, created a philosophical school, whose influence is still every where felt. II is doctrine was dualistic: Matter is created once for all, and has no further need of the Creator. As concems the spiritual world, he assumed minnte, indivisible, intelligent beings, called monads, - constituents of all bodies and all beings. In close relation with him stood Kant, while in England Locke and Hume became leaders of the opposed and materialistic school, declaring the brain to be an organ for the secretion of thought.

Among the miversities founded during the eighteenth century were those of Breslau, 1702; Bomn, 1771 ; Stuttgart, 1781; Pesth, 1794; Göttingen, 1737; and Erlangen, 1743. Medicine was also cultivated in learned societies, which increased constantly in numbers. In 1744 Frederick the Great united two other societies in to his Royal Academy. In Switzerland, in 1751, was founded an association of physicians and naturalists, while in France royal scientific societies were founded at Bordeaux, Montpellier, Lyons, and Dijon, and the Royal Medical Society of Paris lived from 1717 mitil 17S8. In spite of all these opportunities for enlightenment, everything was not yet enlightened. Then de Hä̈n defended the existence of demons, and Maerz, a well-known theological teacher, in 1760 devoted a book to witches and magic. That witches were burned publicly is a matter of history, eren in America. So late as 1821 there was a statute regarding witches in Ireland, and they were burned in Mexico as recently as 1877. But these are flying pictures of the eighteenth century, which are 
meant only for the moment to illustrate the mose serions topic, to which we must now address omeselres.

First of all, the medical systems and, theoritis of the century. Many hundred gears previoushy (ialen land originated a method, which descrves, perhapes, the tithe of pure eclecticism. 'The first purely eclectic syolom sinilin to his originated with Bocrhalve (1688-1738), jerlapes the most fimous physician of his or any other century. He was the

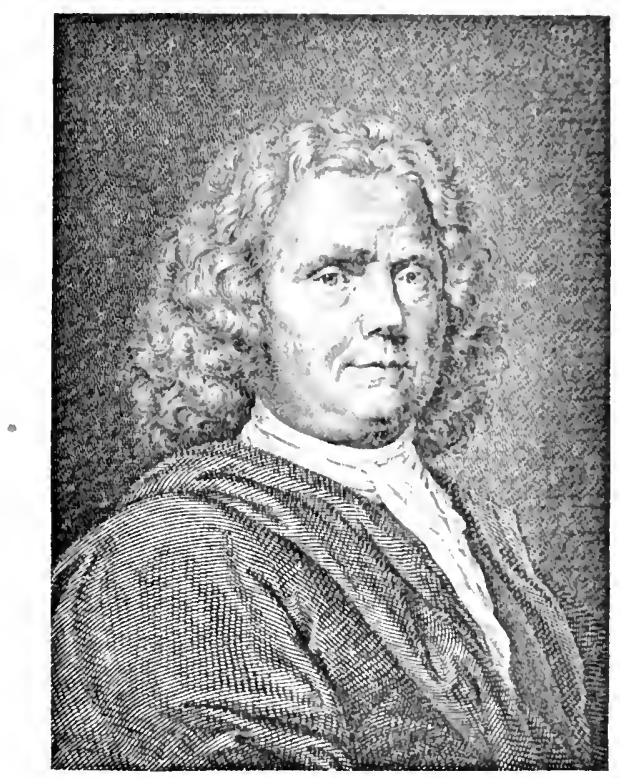

Fir, as-RotritaAve.

(From a steel engraving by Faustino Anderloui of a painting by G. Gararaplia.)

son of a clergyman near Leyden, Holland, and was one of thirteen children. Originally intended for the cherical profession, he had studied philosoplyy, history, logic, metaphysics, philology, mathematics, as well as theology, with great diligence. His elucation was, later, directed to the study of medicine, because of the statement that the purity of certain theological doctrines was endangered by lim. So he studied chemistry and botany, and then anatomy and 
medicine, graduating in 1693. He practiced in Leyden with great success, and was offered a court position. In $17(09$ he was tendered the chair of Medieine and Botany, and in 1714 that of the l'ractice of Medicine; in 1718 he was also made Professor of Chemistry. In all of these positions he displayed the greatest capacity. He was a clinical teacher "of rare talent, and soon acquired such reputation as to attract to Leyden students from all parts of the world in such numbers that no lecture-room in the university could contain them. He was the first to give separate lectures on the subject of ophthalmology, and employed the magnifying-glass in examining the eye. As a practitioner he was no less popular, and he left an estate valued at two million dollars. He was so famous that, when a Chinese official adkressed a letter "To the Most Famous Physician in Europe." it reached him safely. He made no distinction in his patients, and compelled Peter the Great to wait a whole night for his turn to consult him. His most eminent pupils were: Haller, Van Swieten, de Haën, Gaub, and Cullen.

Boerhare's influence and dignity, which were astonishing, even in a phrsician, were based no less upon his encrclopadic attainments than mon the benevolence and purity of his character. He was free from disputatiousness and ranity, although everywhere regarded as an oracle. His miversal maxim was: "Simplieity is the seal of truth," although he never manifested this in his therapentics. He employed the thermometer in the axilla in examining his cases, as did the iatrophysicists of the previous century.

His doctrines did not form a new system, but rather a composite of earlier systems. He stands also in the anomalous position of one who had the whole world at his feet, and yet contributed little or nothing which has been of essential importance. In fact, his peculiar views have been so universally given up that they are of only meagre historic interest. He looked upon disease as a condition in 
which bodily action or natural activities, being distmibed or unsettled, could take place only with difficulty; the reverse of this, of course, coustituted grood health. Fever he regarded as an effort of Niture to ward off death. 1)icrestion was explained, like the circulation, 11)on mealanical principles. In his therapentics, besides his cfforts fo sweetcin the acid, to purify the stomach, to get rid of acridities, lie made Hippocrates and Sydenham his models. IIs hionraphers say that his medicines were less offective than his personal appearance. He left many adherents, but no school of followers. It must be salid, however, to his credit, that, while not the first to give clinical instruction, he permanently established a clinical methor in teaching.

Gaub (1705-1780), prof'essor in Leyden from 1731 , was but little inferior to his master, Boerlanve, in fame as a teacher. He wrote the first complete work on the exclusive subject of general pathologr. In general thorapeutics he considered the healing power of Nature amply sufficient to remove sickness, but attributed this power sometimes to the soul and sometimes to the body.

There arose, naturally, stremuous opposition to the views and teachings of Boerhaave, and his principal opponent was Stahl (1660-1734), who was one of the most important systematists of any age, a profound thinker, and a pioneer chemist. He began lecturing in Jena at once upon his graduation, at the age of twenty-fire, and mored through two or three different university positions until he came to Berlin at the age of fifty-six. He was a great pietist, of uncouth mamners, faitluful to his laboriously arquired convictions, and bitter and relentless argainst those who could not aceept them. Indeed, he resarded his convictions as revelations from God. IIe looked upon the success of another as a personal injury to himself, and from being first a croaker he became finally a confirmed misanthrope, until he fell into actual melancholia. Pecuniary profit he had never sought, and its pursuit he 
sconsed. His riews were dynamico-organic, pietistic, and antagonistic. He regarded the sonl as the supreme principle, life-riving and life-preserving, not to be confounded with the spirit; when hindered or obstructed in its operation, disease was present. 'The soul gorerned the organism chiefly by way of the circulation; consequently, plethora played an important rôle. 'lo gret rid of this plethora the soul employed either ferer or convulsive movements; for eximple, in children plethora produces a pressure of blood to the head, and, by way of compensation, the soul provides a liemorrhage from the nose. For reasons easily appreciated, he regarded bleeding piles as safety-valves of the utmost importance. Fever was a salutary effort of the soul to prescrve the body; this was true even of intermittents, and, accordingly, he never gave cinchona. He scomed anatomy and physiology, saying, in one place, that medicine laad profited as much by the knowledgre of the bones in the ear as by a lnowledge of snow which had fallen ten years previously. But Stahl was one of the most eminent chemists of the age, and did a great deal to liberate chemistry from the glamour of alchemy and the domination of pharmacy, and to transform it into an independent science.

Stahl's doctrine has been called animism, and was a reaction against the chemical and mechanical theories of the seventeenth century. He gained a considerable number of followers, the most notable of them among the French being Sanrages (17(06-1767), the forerumner of lincl and an opponent of prre mecluanics, who animated the mechanical system of the body with Stahl's "soul." This was, par excellence, the age of artificial systems, and so Silurages in his classification supplied a system which had ten classes of liseases, each of which had several orders, and some as many as two hundred and ninety-five genera, and two thousand four hundred species of disease!! Even Limneus had three hundred and twenty-five genera 
of disease, while Cullen had only four chasses with m1n hundred and lorty-nine genera.

'The mechanico-dyuamic sistem was a solt of (o)mpromise or mixed system, which was held in high homolo by the most eminent plyssicians and bettre minds of llw. last century, and has even been prized by siprenged ats the best of all. It was originated by Friedrich lloflmam (1660-1742). Hoffmamm's father was a plysician, and he wats himsell bom in llalle, whose unirersity he attended. He acquired lasting reputation as an oculist, and was made Professor of Anatomy, Surgery, Modicine, Physics, and Chemistry at his alma muter. Our commonplace "IIoffmam's anodyne" is named after him. Ho was one of the most erudite professors of his day, more easily understood than Stahl, widely known for his fhucht diction and amiable temper, and, accordingly, won great renown for his university. His good fortune as a practitioner was so great that even Boerhave declared him his own equal. As a writer he was roluminous, one edition of his worlis comprising twenty-seven laige volumes.

According to Hoffmann's views, life was simply mechanical movement, especially of the heart; death, the cessation of heart-action, putrefaction tlicreupon resulting. Health meant regularity of movements; disease, a disturbance of the same. He used the word "touns" extensirely. Ether he regarded as an important factor, producing and maintaining morements of the body, itself extremely volatile, corresponding larocely to the "pnemma" of the ancients; it was, in fact, a motor principle and, at the same time, the perceptive sonl. Ether was stored in the medulla, and circulated in a donble way in the body; spasm was the consequence of too strong, atony of too feeble, influx of ether. Fever was a general spasm of the arteries and reins, having its cause in the spinal cord. Hoffmann's therapentics were simple, and poor in drugs. These latter were intended to reaken, alter, or evacuate, 
and he was especially partial to the use of vinous remedies. 'The strong and toxic dimes he used but little.

William ('ullen (1 $112-1790)$, a Sicotchman, rose from the drepest poverty to the wreatest celebrity. First a barber, he afterwari became an apothecary. then a shipsurgeon, then a village practitioner, finally entering into partuershlp with William IIunter as a general practitioner. Both of these cminent men being in equally poor cireumstances, they agreed to live in the same place and that, while one was studying. the other should take care of the practice. In this way C'ullen was enabled to graduate in 17t0. Six years later he tanght chemistry in Glasgrow, and $m$ ten years more came to Edinburgh as Professor of Medicine. He continued rery active and famous up to the time of his death, but died as he had been born,-in porerty. Among his numerous other charitable deeds, he was most kind to the fimily of Robert Bums and published the latter's poems.

Cinlen was the father of modern Solidism,-a system based upon the solid parts of the body, the nerves being the chief agents. 'The life-gring element was, in his view, an molefined, dymamic something (different from IIoffimann's ether or Stahl's soul), which he called nerveforce. or nerve-principle; animal force ; and brain-energ!, and in it he included the spinal cord. His nerve-principle was supposed to produce spasms and atony, either actively or passively. The causes of disease, while of a debilitating character, were supposed to awalien reaction of the healing powers of Natme; fever was a reparative effort of Nature, even in its cold stage, the blood playing no part in it. Ire constructed a very arbitrary classification of fevers, as, in fact, he did of all discases, his system of nosology being the secret of his reputation. His explanation of gont was famous. That disorder, he said, depended upon an atony in the digestive organs against which was periodically set up a reparative effort in form 
of a joint inflammation. In serofula lie hat to assmure, in contradiction to his nervous pathologg, a peculiar arrility, and in putrid fever a putridity of the humors of the bods. His therapentics were simple and salutary beranse of his renunciation of venesection, which was murch almosed in his day.

'The most celebrated pupils and surecessor's of Iloftimann were Gregory, of Edinburgh, Gardincr, and, in (iemann, the famous 'Thaer (1752-1828), who finally abandoned the practice of medicine becanse it promised more than it could perform, and who became a "fither of husbandry."

A composite of the doetrine of Hippocrates, Sydenlam, and Boerhave was represented in the so-called Old Viemal School, whose comnection with the lives of Mantia 'l'heresa and $J_{o s e p h}$ II deserves, at least, mention. Its founder was Baron Vam Swieten (1700-1772), of leyden, a descendant of a noble Jansenist family of the Netherlands, who graduated under Boerhaave after having studied at Louvain. After the death of his patron he was called to the assistance of the Archduchess Marria Amna, of Austria, who was suffering from an abortion, and gave such satisfaction that she recommended him to her sister, Maria 'Theresa, who ир to this time had remained sterile. 'T'o her and to her husband he gave advice which resulted in sixteen suecessive pregnancies, and then, as the result of his success, came to Viemna in 1745 as President of the General Medical 1)epartment of Austria. He was also made censor, in which position he incurred the enmity especially of the Jesuits and of Voltaire, whom he robbed of their influence. He was made baron, and became, next to Kanuitz, the most influential comnselor of the empress. His chief care was dedicated to the elevation of medial aftairs in Austria. and especially to the improrement of the medical faculty. He had just seen snecess crown his efforts when he died of senile gangrenc, with the reputation of boing a great physician and benefactor of the poor. One of the greatest of 
liti services was improving the treatment of syphilis, in which he, after the example of laracelsus, recommended the intermal use of corrosive sublimate.

More cmincent as a physician than for personal character was de Hä̈n (170t-i776), of The Hagne,-a pupil of Buerlatie. At the sleggestion of Van Swieten, he was called, in 17jt. to Viemna as president of the clinic of the (ity hospital, which at that time afforded accommodation for only twelve patients. He was the real fomder of the so-called Ohl Viema School, whose merit, in contrast to the so-alled new sehool, is to be sought in practical and diagnostic serrices. As de Hä̈n quarreled with every one, he also dicl with stoerek (1749-1803). the snecessor of Van swieten in the direction of the Anstrian Medical Department, and with Stoll (1742-1787),-a clinical teacher who was especially famous as an epidemiologist.

Stoll lectured with great popmlarity until 1784, upon the completion of the Allgemenes Krankenhans, when he fell into the backigromed and was bally treated. He was the subject of mumerous intrignes by his enemies, and hatd a wife who embittered his life, and who even had him buried in the dress of a Jesuit in order to injure his reputation after his death. 'To his eredit be it sad that, changing his views of the constituents of discase later in life and his original therapentics becoming no longer of 11se to him. he abiudoned them entircly. Nevertheless his therapentir system flomrished for a long time after him.

'There were in rogne during this period numerous other doctrines, some of which were too puerile or insubstantial to gain any foothold at all; others exerted a certain amount of influence during the life-time of their originators or for a grencration alferwad. With many of these I do not care in any way to deal. A few others, I think, onght to be at least mentioned in such a history as I am endeavoring to present.

'There was another Hoffmamn-Christopher Ludwig 
Hoffmam (1721-1807), of "Westphalia, who drised a socalled humoral theory in which the "acridities" of Bocerhat ve were mingled with the "putridities" of the puscumatists and the "irritability" of Gilisson. I Iis tratment and remedies for diseases were supposed to be antineptie, as was very proper when dealing with putridities.

The theory known as the "Doctrine of Infaretus" had its origin with Kample, who died in 1753. Ry infaretus Kampf understood impacted fieces, which he flomght originated in the humors of the body, portal ressels, and intestines; he recognized two kinds, - the hatek bilions and the mucous. From this theory a wide-spread clyster fishlion developed, and lords and ladies ried with cach other in belaboring their infarcti and in administering encmas. As Batas says: "NVe cannot deny to the author of this doctrine at least an extensive knowledge of human nature. Ile supplied a miversal remedial procedure, and gratified the apothecaries with the bulkiness of the herbs required for its practice."

Quite antagonistic to the riews of the Viemna School were those of the Sichool of Montpellier, inaugurated by Bordeu (1732-1796), and gencrally kuown als ritulism. Borden died in the enjoymont of great reputation, but at variance with all his colleagnes. He maintaned the existence of a general life of the body, - a composite life, resulting from the hatmonious working of the individual lives and powers of all the organs, which were supposed to be associated with each other, but each for its own definite function; the most important oreans-the stomach, heart, and brain-being called "the triporl of life." In patholory he laid great weight upon crises, which were supposed to proceed from the glands.

The most important representative of vitalism was Barthez (1734-1806), of Montpellier.- - il man of great gifts and cager for knowledge. IIe recognized a vital principle as the cause of the phenomena of life, but acknowledged 
that its natme was monown, although he endowed it with motion and sensibility different from a thinking mind. Plants were suppored to possess it likewise. 1)isease, he believed. was the result of an affection of this vital prineiple. Every discase was divisible into certain disease-elements, riewed as parts of the whole, and these were again divisible into secondary elements. Lie explanined putrid ferers as sperific vital diseases, -in which riew, of course, he embodied hmmoral ideas.

In Germany, at abont this time, a similar doctrine obtained, - a doctrine of vital forces, - which the versatile Reil (1759-1S13) claborated into a system.

Meantime, in Fingland, a doctrine was elaborated by Grasmus Darwin (1731-1802) which partook, in a certain degree, of the doctrines of Stalıl, Hoffmann, Haller, Brown, and Borden. Erasmus Darwin distinguished himself, not only as a physician, but as a poet, philosopher, and physiologist. He was a friend of James Watt. Of his life it is said that by his practice and very fortunate marriages he became wealthy, ate much, and drank nothing but water. I is chief work-entitled Zoönomia, or the Laus of $\mathrm{Or}$ ganic Life-was published in 1784 , and is well worthy of perusal to-day. Ile recognized two fundamental substanees -spirit and matter. But it is not so much for his doctrine as for his rescarches into animal and plant plỵsiologr, and, reflexly, because of his more celebrated descendant of the same name, that we owe him most gratitude. 


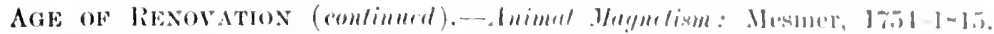

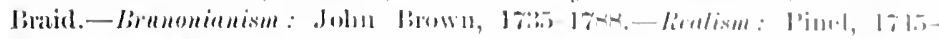

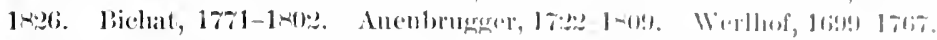

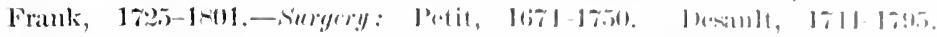

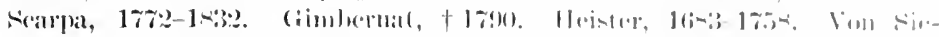

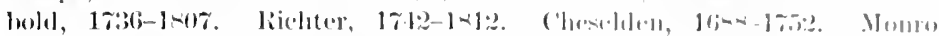

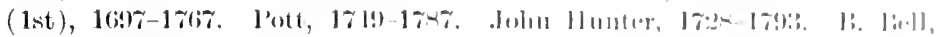

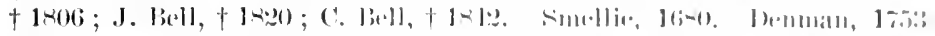

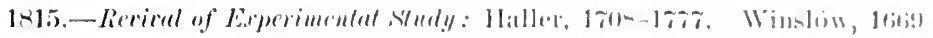

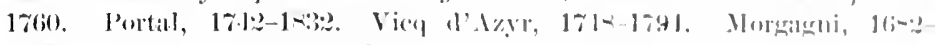

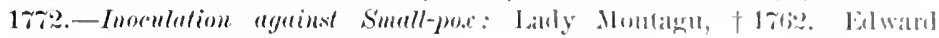
Jemer, 17.19-1 823 .

Duning the eightecnth century also arose the illusory doctrine of Animal Magnetism, which obtained among all classes a following that can be accounted for only by the attractiveness of the marvelons and unexplained. Fank Mesmer, born near Lake Constance, in 1754, was early a victim of romantic yearnings, and his graduating thesis, delivered in Vienna, dealt with the influence of the planets upon man and the use of the magnet. After traveling extensively he erected a private institution, where lie treated blind girls, fidgety old maids, and simpletons. until his deceptive methods were unmasked by a commission appointed by the Empress Maria 'Theresa. and he was compelled to leave Vienua in twenty-four hours. This martyrdom recommended him in Paris, where the so-ealled Mesmerism speedily became fashionable. He finally undertook instructions in magnetizing, at the rate of 100 lonis a head, and founded the "Order of Harmony." His so-called baquets were tubs with magnetic ducts. partially filled with soft water and all kinds of ingredients, and armed with iron conductors, with which his pupils, joining hands, placed themselves in contact. At these séunces Mesmer appeared in lilac-colored clothes and professed to reinforce the action of the tubs by looks, gestures. plaring upon the harmonica, and touching the subjects with wand or fingers. "If" any" 
one, particulary a lady, had a crisis at this time, she was bolne to the 'crisis-chamber' by Mesmer himself, where he treated her alone, as only when alone, he claimed, could lie attain suecess." He speedily became wealthy; man-

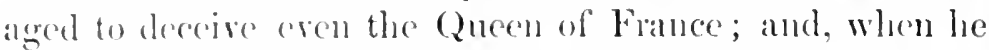
threatencel to deprive the combtry of his presence, 20,000 frances wore offered him to instruct others in his art. This offer, howerer, the wily charlatan declined. In 1785 some fool penued an artiche extolling him as a worker of miracles; this stimulated the anthorities to organize a rommittee of investigation, the adrerse decision of which, along with some contributory cridence, made l'aris too warm for him. After the revolution he returned, but his day had passed, and he figures no more in medical history. lle has had many imitators, and the mesmeric craze, at times, lats infested different portions of the civilized globe; eren some who were eminent in science have fillen into the suares of so-called Mesmerism,-notably Olbers, the discoverer of a mumber of asteroids. Mystic medical doctrines, fommed mpon Mesmer's views, still continue in rertain circles, though the majority lave long since succumbed to the adrances of scientific psychology. In this connection it is proper to speak of the revired interest in "animal magnetism" due to the researches of Dr. James Braid, of Manchester, England. This gentleman, in 1842, published a work which pretty thoroughly exposed the fallacies of the doctrine of Mesmer, and expounded many of the truths that were entangled therein. Ife was among the first, perhaps, to employ the phrase "animal magnetism," and was the author of the term "hypuotism," though in his day the popular title was Broidism.

1)uring the middle of the eighteenth century arose a doctrine that, in its norelty, ease of practical application, and apparent consistency (through the ingenious employment of certain vital phenomena), secured such a hold that its influence continued even into the present century. 'This 
was the "Brumonian doctrine," promulgatert and upheld by the great foe and rival of Cullen,-boctor John limwn. In youth very precocious, though of most humble hirfl. Doctor Brown had mastered the Iatin langruage at the: early age of seven years, and three years later essityed to learn a trade. At the age of twenty he left his mative village of Dunse for Echinburgh, secking employment as a tutor and intending to study theology. l'overty soon com-

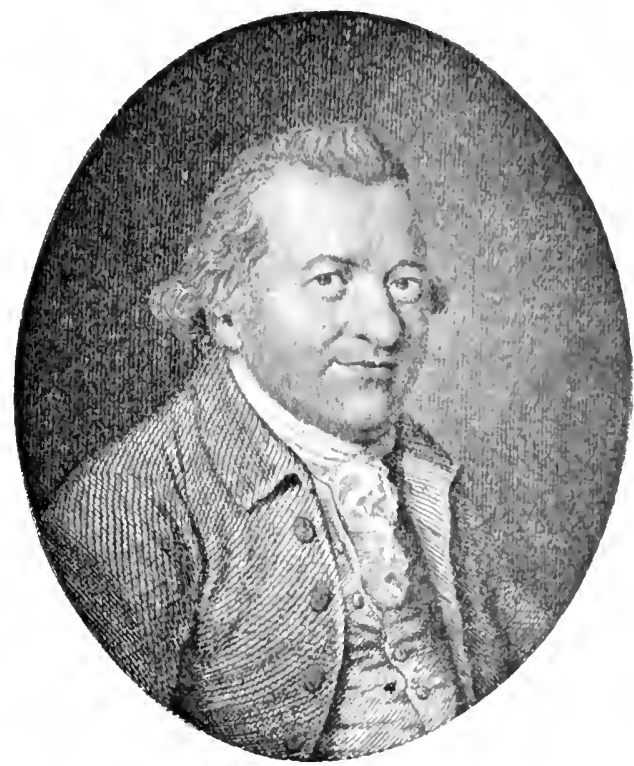

Fic. 29,-JohN Brown, M.D.

(From a steel engraving by J, Caldwell of a miniature printed by Donaldson.)

pelled him, however, to take a rural school, but he retuned a few years later (in 1759) to the Scottish Athens and began the study of medicine, supporting himself mantime by rendering theses into Latin and by teaching, translating, and quizzing. Finally, he attracted the attention of Cullen, to whom he became useful through his knowledge of the classics; but, ultimately, a foolish quarrel made bitter enemies of the former friends. In $17 \% 0$, in private lect- 
ures, Brown began to advance the theory to which he had been led by one of his own attacks of grout that disappeared under the use of stimulants, the disease having previously always been aggrarated by the treatment prescribed and that was held to be orthodox,-viz., antiphloristic. He had now become somewhat dissolute, and the students he gathered about him were of very much the same character; but they formed the nidus of a great following opposed to Cullen, and quarreled on all occasions with the adherents of the latter. Finally, Doctor Brown removed to London, where fortune seemed to smile upon him, as he gained rapidly in reputation and practice; indeed, he barely missed a call to Berlin and another to Padua as a teacher, the scale being turned against him by his dissolute habits. Though possessed of the highest mental gifts, Brown was unfortunate in lack of mental stamina. He taught that life is not a natural condition, but an artificial and necessary result of constant irritations; all living beings, therefore, tend toward death. Health is an intermediate grade of excitement; diseases, which are either sthenic or asthenic, represent either too high or too low a grade of excitement. It has been said that Brown's teachings slaughtered more human beings than the French Revolution and the wars of Napoleon combined. In England this system found no important followers, but in America Benjamin Rush, of Philadelphia (1745-1815), distinguished himself as an adherent. In Spain and France it found little place; but in Italy, and later in Germany, it secured a numerous and important following, which numbered, among others, Scarpa, Massini, and Girtamner.

Another system which attained influential development, extending even into the present century, was the so-called Realism, originated by Pinel (1745-1836). Born in porerty, and designed for the Roman Catholic Church, Pinel did not turn lis attention to medicine until his thirtieth 
year, but on completing his stulies he mplidly mose to positions of importance. Iad to the insentigation af mental discases by the fate of one of his partienlar friend. who had become insanc, escaped into the forrest, and wath there devoured by wolves, Pinel sperelily doveloped at grout interest in this elass of suflerers. 'l'he lot of the insine at this time was most pitialble: they were imprisoned, chained, and treated worse than wild beasts. In his efforts to jun-

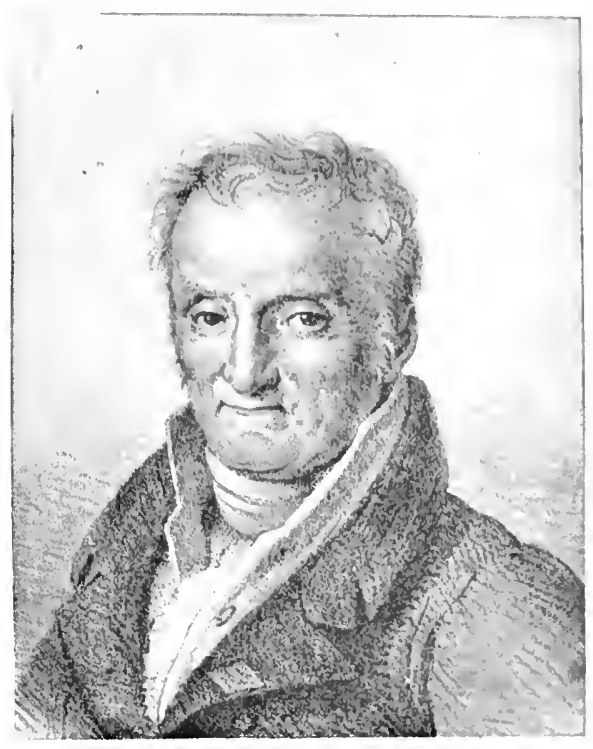

Fig. 30.-PIr. PINEL.

(From an old hithograph of the tighteenth century.)

prove their lot, Pinel acquired the title of conservative and aristocrat, either of which was almost equivalent to al deathsentence. Unterrified, however, he appeared before the Paris Council and urged the adoption of reformatory measures, replying to the challenges of skeptical and selfregardful opponents by liberating a number of insane patients who were in his charge. The comrage thus exhibited receives appreciation in our time, if never before. Not the 
least of Pinel's services was the substitution of analytical for syuthetical methods; he also sought to determine disease by a diagnosis arefully constructed from symptoms, hut infortunately lie made pathology and anatomy subordinate tautors. He was a pupil of Barthez, but he placed his preceptor's ritalism fir in the background.

François Hichat, born in 17\%1, earned high rank both as a clinician and an anatomist. His education was begun in Nantes. but he studied surgery and anatomy in Lyons and Montpellier, subsequently going to Paris, where he became a nember of Desault's family. After the death of his patron lie lectured on surgery, and from 1797 on anatomy. Possessed of a feverish scientific activity, he became a member of the Société d'Emulation. Death orertook him in 1802 as the sequel of consumption and an injury received through a fall. He was the most capable physician of France in his time, and, brief as was his span of life, he was author of nine important volumes, the chief of which were a Treatise on Membranes and works on gencral and patlological anatomy. From the latter a new tendency in study took origin. He it was who gave utterance to the aphorism: "Take away some fevers and nerrous troubles, and all else falls to the kingdom of pathologrical anatomy." As an evidence of his energy, it is related that he in one winter examined seven hundred bodies. He taught how to discriminate between disease processes, and notably subdivided peripneumonia into pleurisy, pnemmonia, and bronchitis, these having been previously confounded. He once remarked: "You may observe disease of the heart, lungs, abdominal viscera, etc., night and morning by the sick-bed for twenty years, yet the whole furnishes merely a jumble of phenomena which unite in nothing complete; but if you open a few bodies, you will see the obscmity speedily give way, - a result never accomplished by observation if we do not know the seat of the disease." 'To Bichat is also due our modern recognition 
of cellular, osseous, fibrous, and other tissues, as such, wherever they appear throughout the hody. Ile differentiated, without the aid of the microscope, twenty-one different tissues as simple and similare elements of the body, enumerating them as one does the chemical clements; lix. described the stomach as composed of mucous, scrons, and muscular layers; orerthrew the speculative tendeney of medicine, and placed facts in the front rank; and so

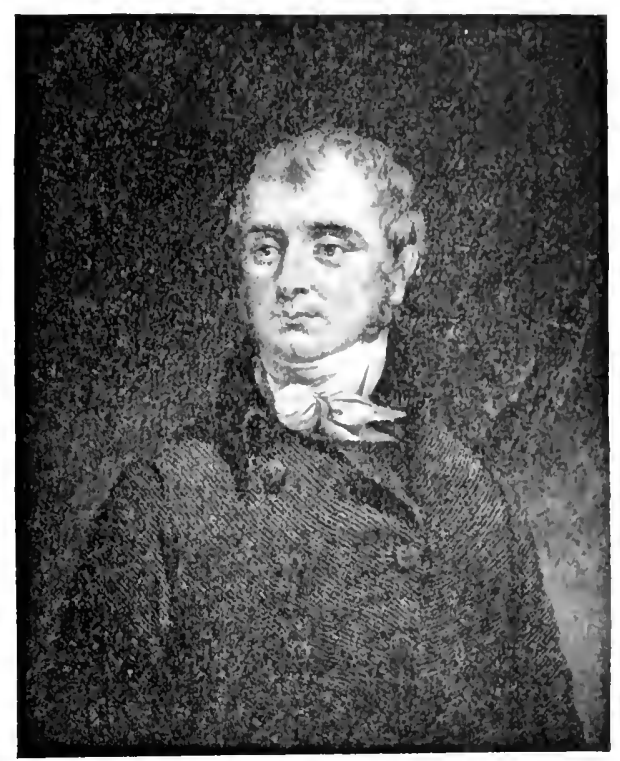

Fra. 31.-Marie Francois Xavier Jichat, M.D.

(From a steel engraving by 11. Cooke of a painting by Vigneron.)

conspicuous were his services that he has been termed the "Napoleon of Medicine." He supplemented the influence of Pinel upon the side of pathological anatomy; called sensibility and contractility vital propertics, whose alterations constitute disease, claiming, however, that the vital properties of individual tissues differed among themselves. His life and works are rerelations to young men, and show what can be accomplished at a very early 
age by sufficiently active and harmoniously dereloped brains.

In reviewing the theories and lives of those mentioned as medical luminaries of the eighteenth century, one experiences a feeling of mingled respect and disappointment -respect for the deroted way in which they worked and sought for the truth, and disappointment at so much waste of intellectual power and labor. The lesson is also taught, and should be impressed, that in all so-ealled new systems old principles for the most part reappear, and that the labors of the past are rarely so deliberately consulted as to guard against repetition and revamping of theories that had long before been proved futile.

Let me now mention a few other of the physicians of the last century who have left more or less of an impress upon their successors and upon our science. One man. in particular, historians are wont to remember with the honor that was denied him by his colleagues and contemporaries. I refer to leopold Anenbrugger, who was born in Graz in 1722 , and who, after pursuing his philosophical and professional studies in his native city, obtained, at the age of twenty-nine, charge of a Spanish military hospital; while thus employed he invented the art of percussion as applied to diagnosis. 'This he gave the test of experience during seven long years before making it linown to the profession, and even then it was not appreciated, but remained practically umnoticed until after lis death, which occurred in 1s09. He did receive a patent of nobility from the Emperor Joseph II, but this hardly compensated him for the contumely heaped upon him by his colleagues. Paulus Erineta employed somds and specula; Santoro used the balance, comnted the pulse, and resorted to the use of the thermometer; Boerhaare employed the thermometer and the simple lens; Floyer, and after him Haller, utilized the watch in marking seconds; a Salernian practitioner utilized auscultation and percussion in tympanites and ascites; but 


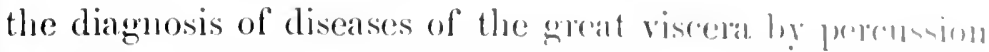
was never known before Anembrugarel. Ilis busklet of twenty-two pages, musalable in his time, is to-rlay ludil

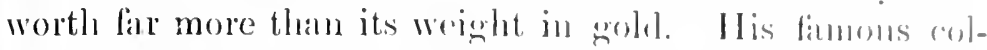
leagne, de Ilä̈n, wrote fifteren volmunes withont a word on

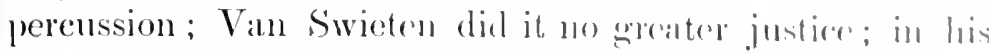
great treative on the Mistory of Medirime. Siprengen bandy alludes to it; yet the contents of Anembromerers boukled were of more practical value than all that thene of her mon ever wrote, or all the results of the rast and blombly ranpaigns during which it slept. In lsos this volumo was rescued from oblivion by Corvisat, who translated it into French and prockimed its undying value.

I) ring the earlier part of this centmy lived Wrilhof, of Helmstädt (1699-1767), a farr-fimed obscrver, anthor, and practitioner, who deched a professorship, and ('specially distinguished himself as a writer of German poetry. 'J'hough possessed of an exceptional knowledge of modrun tongues, he wrote only in Iatin,--the scientific language of the day. In 1734 he was appointed physician to King George Il, in which position he attained world-wide timm, while indelatigable in his efforts to elevate science. He first described the disease known by his namc. - monlus maculosus Werlhofii,-and struggrled hard to establish in Germany the use of cinchona.

From 1740 to 1802 flourished Wichman, of Hanover, highly esteemed as a writer and practitioner. He is especially known for his pleas in firor of more scientific diagnoses, and his demonstration of how to malie them. The rôle of the itch-mite in the transmission of scabies lie demonstrated upon himself; to be sure, Bonomo, a humdred years before, had called attention thereto. but with little avail.

Another eminent Hanoverian was the fickle. stmbborn, and misanthropic Zimmerman. born in 1728, in Berne, upon whom misfortune and disease played many shabby 
tricks. He was, however, a man of ingrenious endowments, and merits especial regard, because he sought to free medical science from the charge of being a secret art.

Another of the prodigies of medical history was J. P. Frank, born (17:5) in the Bavarian Palatinate, of pauper parents. and, while an infant, abandoned by a cruel father. Ilis early life was passed in a religions school; at twentyfive he became a colat and garrison physician, and later a professon in Gütingen; funlly he went to Vienma, where he died in 1 801 . He was greatly beloved by his pupils, and Walther, the famons surgeon, said of him: "No one ever made so elevating and permanent an impression on me." He published an extensive work on forensic medicine and sanitation,-wherein he took up the hygiene of the individual, of the family, and of the school,-which constituted an effort far aliead of anrthing of the kind previously known. He is also memorable for efforts toward increasing the population, for the 'Thirty Year's' War had depopmlated extensive districts-to such a degree, indeed, that in 1750 bigamy was legalized in Nuremberg and many other towns. Frank was distinguished for a keen and even canstic humor, whose subject was not infrequently himsclf.

From 170 to 1782 there lired in England one Sir Joln Pringle, chief of the Army Medical Department, known to this day as an anthor upon military hygiene. John IIuxham (1794-1868) advanced our linowledge of putrid dissolution of the blood. John Howard (1766-1790) rendered eminent service in prison reform. ILeberden (1710-1801) was the first to describe varicella, and also angina pectoris-which was long known as Heberden's asthma. John Fothergil (1712-1780), a Quaker, acquired fame by his observations on chronic angina, nemalgia, and hydrocephalus; was likewise a benefictor of the poor, regarding them as "bridges to the pockets of the rich"; indeed, a large part of what he gained from the latter 
class he bestowed in charity, and at, his drattl loft

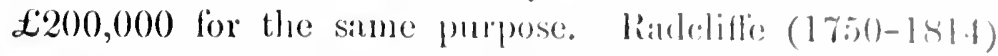
was an eminent, witty, sucerssful puatitionrol of lomden, who was wont to declale that, as a youmer manditioner. he possessed twenty remedies for every discase, hut at the. close of his career had fonnd twenty diseases for whirebs he had not one remedy. Richand Mearl (16i3-17ij) was a prolific writer, and the anthor of the first qualantine regulations adopted in Fongland. Contemporary with Mead was lettsom,-the busiest, most philantluropic, and most successful physician of his day,-whose practice, although a large part of it was mratuitous, hought him sixty thousand dollars a year, and who gave away immonse sums for charitable purposes; also. Thomas J)orer, who invented the sedative known by his name and who diod in 1741. Akenside, physician and poet (17:21-177(0), wrote on dysentery. Baillie, of Edinhurgh, was the first to accurately describe the morbic anatomy of gastric ulcer.

Among the French surgeons must be mentioned la Peyronie, of Montpellier, born in 1668, who ultimately became director of the Academy of Surgery and surecon to the ling. His wealth was employed for the elevation of the craft, and he founded no less than ten diffrent surgical professorships at his own expense. In 1743 he effected the separation of the surgeons from the barbers. He died in $17+7$, dedicating his estate to the purpose for which he had lived. 'The most fomous of the earlier surgeons of this century was J. 1. Petit (167t175() ), inventor of the serew tommiquet. and who was called to treat Augustus the Strong, of l'oland; indered, several other crowned heads became his patients. Garenreot (1688-1759), a professor in the College of st. Côme, published a work on operative surgery. Morand (1697-1773) and le 1)ran were distinguished surecons of Paris, the former especially noted for the number 
of times he performed paracentesis. Famous lithotomists were le (ant and fròe (ôme, -whose real name was baseilhac, and who operated by means of the lithotome caché. Astruc (1685-1766) was a syphilocrapher of extensive attaimments ; (2uesmay (169t-17it), an eminent and mulanuted surgeon of I omis $\mathrm{XV}^{r}$, who wrote on the history and progress of surgery in France; Brastor (1721$177(i)$ was hest known for his method of distal ligation in ancurism; Sabatior (1732-1811) wote a famous treatise on operations, in which he recommended resection of the head of the humerus.

One of the most celeluated surgeons was P. J. Desault $(1 \tau+t-1795)$, the son of a poor farmer, orignally designed for the priesthood. but who, after obtaining a thorough mathematical education, beran the study of surgery with an ignolant master of his native town. Subsequently he went to l'aris, and here supported himself by teaching, gradually rising, step by step, until, without collegiate education, he became profossor and chief-surgeon at the Hotcl-1)ien, where he established the first surgical clinic. ILe opposed violently the prevalent abuse of the trepline, and was also a champion of healing by first intention. A trunted firiend of I)esault was (hopart, well known because of the amputation of the foot that bears his name. Another well-known surgeon, likewise a friend of Desault, was Doublet; and it is somewhat remarkable that Desault, (luopart, and Donblet suffered persecution and perhaps martyolom in commection with the supposed death of the Ianphin of France,-properly lonis XVII,-in 1795. There is evidence that the child who died in the temple was not the damphin, but a substitute, and these three surecons, who examined the corpse, had the hardihood to express their doubts. The same day that I)esanlt reported upon the evidence he was invited to dimmer by some members of the Convention, was taken ill at the table, and died almost immediately after his return home. A few 
days later Chopart and J)oublet died, also muler nusterious circumstances.

Daviel (1796-1862) is remombered amoler formelt surgeons chicfly for extraction of the lans as an independent method of treating cataract; 'l'onom (1724-1816), for his writings on the anatomy and discases of the crop and Anel for originating the operation for ancmrism mistakenly attributed to Hunter. 'There were also many others, of lesser note, who distinguished thrmsclures through special services to surerery or some of its branches.

Among the Italians of this century may le mentioned Scarpa (1772-1832), of Motta. professor suceessively in Modena and Pavia, and who advaned on knowlerlege of hernia, diseases of the eyes, anemrism, and gencral anatomy.

'The most fimous Spanish surgeon was Gimbermat. of Madrid (1742-1790), for a time professor in Baldeelona, who also becane distinguished through anatominal researches.

German surgeons did not rank high dming the calier half of the last century, owing to the contempt engendered by the church for this branch of the medical art. 'I'he fashion of imitating the French, however, led to some surgical development. 'The first German surgeon of scientific education was Heister (1683-1758). of linukfort-on-theMain, who, mable to obtain lionorable employment in the military service of his own comutry. entered that of Holland, where he remained until the experience of his own nation had brought about a healtly reaction. In 1720 he came to Helmstadt, where he developed great activity in anatomy, surgery, and botany; also distinguished himself as a dentist and oculist, and discussed the whole range of surgical topies from the least to the greatest.

Bilguer (1720-1796). of ('hur, became surgeon-gencral in Berlin, and performed the first resection of the wrist in 
1762 ; he was an opponent of amputation, which at that time was altogether too frequently practiced.

Von Siebold (1736-1807) was the founder of an institution for surerical instrurtion, where, for the first time in Germany, surgery was tanght elinically. He became one of the most famous teachers, and was first in his native land to perform the operation of symphysiotomy, so recently revived

The greatest German surgeon of the eighteenth century, however,-one eminent both as writer and operator, - was Angust Gottlieb Richter (1742-1812), of Zorbig, a descendant of a ministerial family, who wrote a famous work on hernia, and greatly improved all branches of surgery; he it was that enunciated the principle of dressing wounds "quickly, easily, and rarely."

Among English surgeons of the century must be mentioned, first of all, Cheselden (1688-1752), whose name is inseparably comnected with anatomy and pathology as well as surgery At first a warm advocate of the high operation for stone, his dexterity in lithotomy excited the wonder of his contemporaries. He pullished a treatise on anatomy, and one on the suprapubic section.

Alexander Momro, Sr. (1697-1767), of Edinburgh, was also eminent in both anatomy and surgery, and contributed more than any other one man to the success and reputation of the Scottish medical school. His sons, Alexander and Donald, and his grandson, Alexander (3d), were equally celebrated in anatomy.

Charles White, of Manchester, is generally credited with haring performed, in $1 \% 68$, the first subperiosteal resection of the head of the humerus, although, as a matter of fact, this was not done until 17rt, and then by Bent, of Neweastle. IIe also performed resection of the hip-joint upon the cadarer-another of the same name, Anthony White, having done the operation on the living subject in 1721. He invented the method of reducing dislocation of 
the humerus with the foot in the axilla, - it prosedure flat is ordinarily ascribed to Sir Astley Cooper; also operations for false joint by the removal of the involved surfices of the bone.

It will be seen that the excision of the joints was peculiarly an English method, the elbow-joint having been first excised in 1758, by Wainman, and the kner-joint by

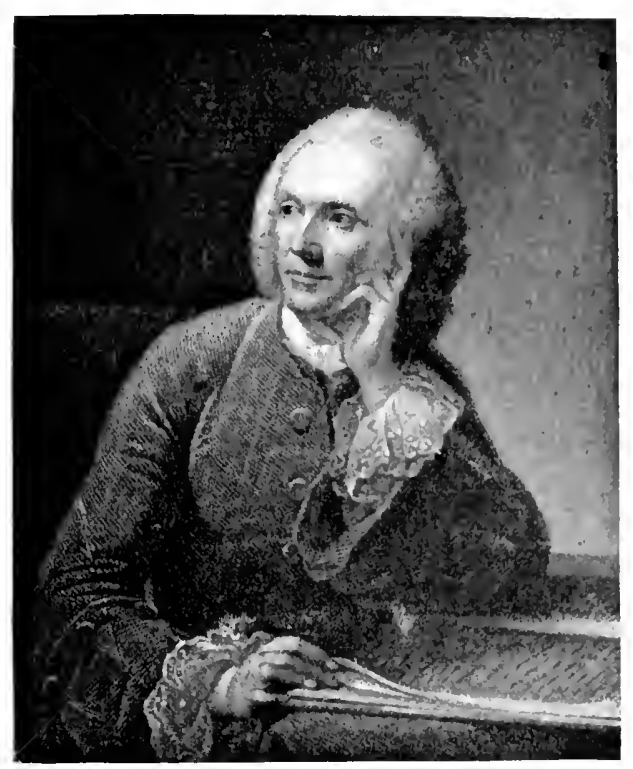

Fig. 32.-WILLIAג IIUNTER, M.D., F.R.S.

(From a steel engraving by $\mathbf{J}$. Thomson, nate from a painting hy $\mathbf{P}_{\mathrm{y}}$ ne.)

Filkin, of Northwich. The man who permanently attracted the attention of surgeons to these new operations was Henry Park, a bold surgeon, who wrote in 1782. The merits of these methods were then soon forgotten, however, and were revived in the present century by liston and Syme.

One of the best-known London surgeons was Percival Pott (1749-1787), who became especially eminent through 
his studies upon hernia, spinal disease, and diseases of the bones and joints; his complete chirurgical works appeared in Iondon in $17 T$

William Inunter (1718-1753), of Scotch parentage, originally a theological student, and a pupil of Cullen, went to i.ondon in $17+1$, began to lecture on anatomy and surery in $17+6$, and soon acquired a great reputation as a surecon, obstetrician, and anatomist. He achicred enormous suceess in practice, and spent $\$ 100,000$ upon his house, library, and private collections. 'The latter now form the Hunterian Musenm in the University of Glasgow. His magnificent plates illustrating the gravid uterus required the labors of twenty years and appeared in $17 \tau 4$.

John Inuter (1728-1793), younger brother of William, enjoyed even greater reputation than the latter. He was a pupil not only of his brother, but also of Cheselden and Pott. Beginning the practice of surgery in 1763, he became surgeon to St. George's Hospital in 1768, and Surgeon-gencral of the English forces in 1790. So memorable were the labors and services of this man that at the Royal C'ollege of Surgeons, of Jondon, there is given annually an "Hunterian Oration," intended in some way to commemorate his labors or to draw some lesson from his life and work. 'To do justice to John Hunter wonld require a volume, heuce we must at present dismiss the subject with this brief reference.

Almost equally famous as a surgeon. though by no means such an ommirorous student as Hunter, was Benjamin Bell, of Edinburgh, who died in 1806. He employed tubes of lead and silver for the purpose of drainage. Sir Charles and John Bell, also of Edinburgh, are eminent names pertaining to the latter part of the eighteenth and first part of the nineteenth century. The latter was Professor of Anatomy, Surgery, and Obstetrics, a busy practitioner, a fertile writer, and not only one of the most successful operators of his day, but an excellent classical 
scholar; his Principles of Surgery appeared from lin()l to 1807. Sir Charles, who died in 184", belongs more to the present century, but was cqually distinguished as an operator, surgeon, and writer, and best known, furhaps, for his Bridgenvater Treatise one the Ilemel.

Among the 1)utch an eminent surgeon was Peter ('imper (1722-1789), who, in order to acruire manual dexterity, learned to use various mechanical tools. Ho was at

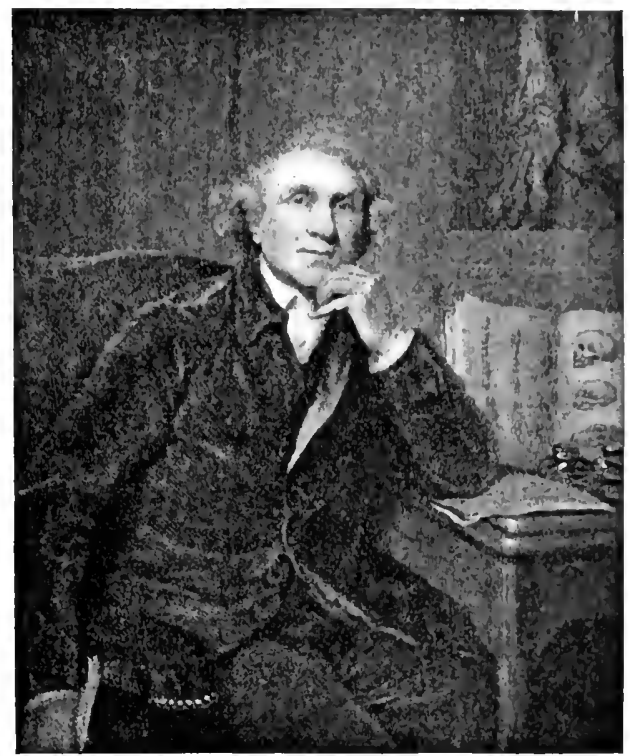

FIG. 33.-JOIIN IITNTFR.

(From a steel engraving hy G. II. Adcrek of a painting hy sir dishua Reynolids.)

fruitful anthor, and did not consider it beneatl his dignity to write a treatise about the best form of shoes. published in Vienna in 1782, but recently translated and republished in England as something new. Sindifort, of leyden, discussed ruptures, dislocations, etc., and reported the first observation of downward dislocation of the femm.

As already noted, the surgeons of the eighteenth century were often obstetricians, - Milliam Hunter conspicu- 
ously. The most important obstetrician of his time was William smellie (1680-1763), of Isondon, who invented numerons instruments, wrote a large treatise on the theory and practice of midwifery, and greatly advanced our knowledge of deformed pelves. He was the first to distinguish one diameter from the other, and to point out the importance of cephalic version and version of the breech. larenthetically, it may be remarked that William Hunter, great as lie was, was the uncompromising foe of instrumental midwifery, and was in the habit of showing his forceps, covered with rust, as evidence that he never resorted to such aids. A rival of Smellie and Hunter was 'Thomas Demman (1753-1815), best known, perhaps, because of his demonstration of the portability of puerperal infection.

The researches of anatomists during the eigliteenth century were, for the most part, directed toward the minute, more difficult, and less striking parts, and to increased thoroughness and accuracy of description. Microscopical anatomy suffered a relative quiescence. Pathological and general anatomy, which were destined to control the medicine of the succeeding century, were newly created and not yet regarded as sciences by themselves, but merely as special branches. The most important feature was the reviral and more accurate study of experimental physiology, which had been scarcely resorted to since the time of Galen, except for Harrey's discoveries. This revival, which really seemed an epoch in the history of medicine; was effected by the great Haller (1708-177\%), of Berne, - a man who really deserved the title of "Great," as he was a universal and indefatigable savant, possessed of thorough conscientionsuess, marvelous capacity for work, great ingenuity, natmal endowments, and an inextinguishable love for art and science; he was certainly one of the inost versatile scholars and thinkers of any time, distinguished not only in his chosen field of medicine, but as a 
poet, botanist, and statesman. Like all Swiss prets, lre never passed beyond the didactic and the homely in his versification. From his tenth year he wrote proms in Latin and German, and even when eight yours old hanl made most extensive compilations from liayle's dictionary. At fifteen he went to the University of 'T'iilingen, where, in the second year of his sojomm, he disputed with one of his teachers. In 1725 he went to Leyden, where Bo(c)have and Albinus foumd in him a most indelatigalbe follower. At nineteen he received the degree of doctor. In the excess of his zeal for anatomy he purchased for a considerable sum, from Albinus, hall of a corjuse, the other half of which his teacher had dissected; and, while in Paris, he even engaged in gratre-robling, and, bring betrayed by his own carelessness, was compelled to salve himself by flight. In many other States, and in more than one country, he studied with the best of teachers, lecturing at times himself. At the age of twenty-six he became professor and hospital dircetor at Berne, and in 1752 pul)lished his famous researches on intitability. Three years later he accepted a call to Göttingen as Professor of Anatomy, Surgery, Chemistry, and Botany. He wats the founder of a botanical garden; for many years was so busy that he slept and lived in his library; and, in spite of his enormous and mique correspondence with the suvents of the world, he never left a letter manswered. Strange to say, his permanent influence upon the practice of medicine was only indirect; and, although he was professor of surgery, and performed many vivisections, he was never able to persuade himself to perform a single surgieal operation upon the living human being. He it was that introduced into Germany the use of the watch in comnting the pulse. Like Hunter, Haller demands a special historian. and it is possible here to outline only a few of the services he rendered to medicine. He enriched the anatomy of the heart, of the brain and dura, and pointed out the venous natme 
of the simuses; taught that the uterus should be regarded as a muscle: advanced the linowledge of the lymphatic system, and believed in and tanght a developmental theory that every individual is descended or derived from a preceding one. In the mechanism of the heart his doctrine of imitability especially mantaned itself. I Ie administered the death-blow to the doctrine of vital spirits, and was, in fact, the father of modern nerve-physiology. His doctrine of initability moved the minds of his century in a way that has no parallel, muless we compare it with the doctrine of Darwin. Glisson had established the general principles of irritability, and Inaller followed, teaching it by the inductive method, and proving its existence by experiments, - proving, moreover, that it is a peculiarity of the muscular substance and not governed by ordinary sensation. His researches deserve the more credit because he lacked modern aids to physiological study. 'The' first physiological institute was fomded in Breslau by Purlinje, some fifty years ago. Haller luad no such opportunity; even his successor, the great Müller, possessed no such adrantages. 'The profound impression made by Haller's teachings may be measured by the number of his supporters and opponents; he was a great man, second only in wide-spread influence to Boerharve, and one who left a more lasting impress upon the world than eren the latter.

'The two best known of Haller's opponents were: Wolf (1733-1794), of St. Petershurg, who regarded each generation as an actual new creation, and was the first to teach the doctrine of the blastodermic membranes; and J3lumenbach (1752-1840), of Gotha, who did great service by investigations in general anthropology, of which he was, in fact, the founder, and whose researches in comparative anatomy and the history of development have rendered him famous.

Of the famous anatomists of the century may be mentioned Sömmerring (1755-1830), of Frankfort,- - the first 
to distinguish the facial and anditory nerves firm and other, and whose published works are well known, lwanur of the beantifil illustations fimished him hy the well. known artist, Iocek.

'The ablest French anatomist of the rentury was Winslöw (1669-1760), -a man of l)anish bith, bit wh

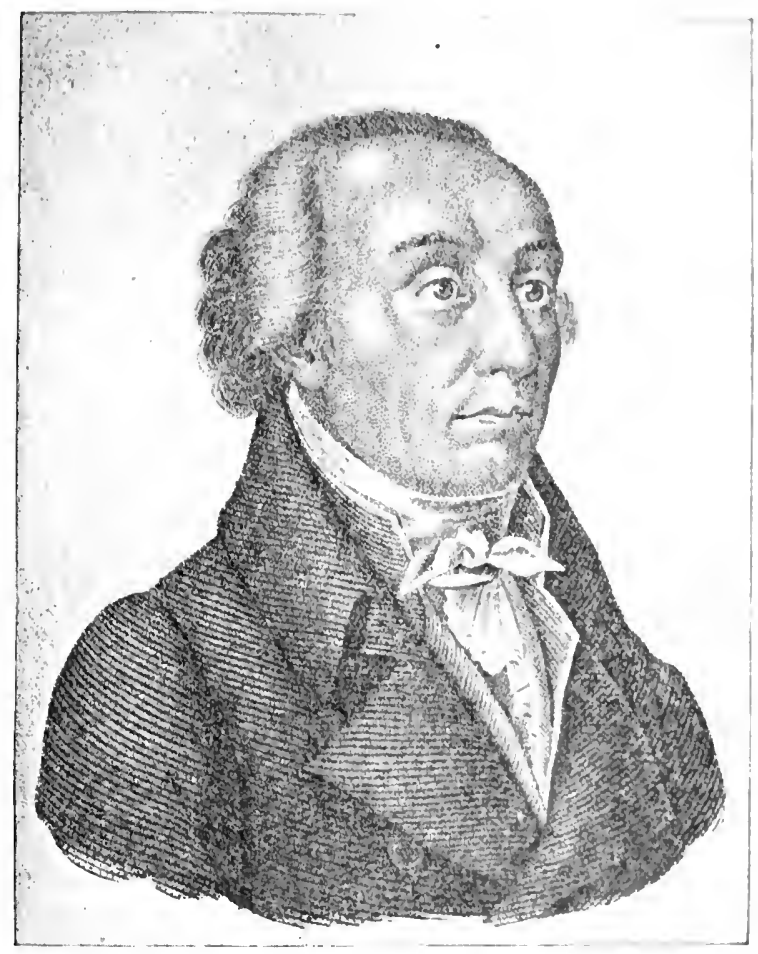

Fig. 34,T. F. Bhumexich.

From :un old steel engraving.)

became a professor in Paris, and is best known by the foramen named for him. There were, also, l'ortal (1742-1832), physician to Lonis XVIIl. who wrote a famous history of anatomy and surgery; and Vieq d'Azỵ (1748-1794), known equally well for his labors in the department of anatomy, especially of the brain, nerrous 
srstem, and the vocal organs. Bichat (already mentioned) would deserve to be placed at the head of French anatomists were it not for his superior rank in clinical medicine.

The founder of pathological anatomy as a science was Morganni, bom in 168:. in Forli, Italy, -a pupil of Valsalval, and. at the age of nineteen, the assistant of the latter. It was not until his seventy-ninth year, after he had published sereral works. that he allowed his famous work on pathological anatomy to appear. This is the historical classic, De Sedibus et Cuusis Mortorum, published in Venice in 1761. Its famous author did not cease work, even when he became blind, and to him we owe the maxim that observations should be "weighed, not counted." He was verr versatile, and well informed in all branches of science and literature, and possessed a remarkable memory; likewise was the first to derote attention extensirely and thoroughly to the anatomical products of common diseases, since, before his time, little had been regarded but rare discoveries in the body. He also called attention to the important bearing which the history of the disease has toward its products, and found his discoveries of advantage, even when they were mable to promote the cure of disease, becanse of the light which they threw upon physiology and normal anatomy, and because they prevented incurable patients from being continually tormented with drugs intended to cure them; also because pathological investigations alone could settle disputes in diagnosis and matters of honor among physicians. He died in 1772.

Morgagni's legitimate successors in Great Britain were Baillie (1761-1823), a son of John Hunter's sister, and Sir Everard Home,-Hunter's brother-in-law, - who became profewsor in the Royal College of Surgeons, and was intrusted by Hunter with the work of describing his collection. Ilome, however, in a most discreditable way, bumed several volumes of Hunter's own descriptions, in order to appropriate to himself the sole credit of the work. He 
has gone down to fame especially because of his book on the prostate.

One of the most notable events in the history of modi. cine was the introduction of the systrmatio praction of preventive inoculation against smull-pox. It is so grencelally tanght that this is entirely due to the offorts of Jenuer -or, rather, we are so often allowed to think it, withont being tanght otherwise-that the moasure deserves an historical sketch. 'The commmnication of the natural discase to the healthy, in order to afford protection, - or, in other words, the communication of small-pox fo prevent the same,-reaches back into antiquity. It is mentioned in the Sanscrit Tedas as performed by Bralmmins, who employed pus procured from small-pox vesicles a year before. They rubbed the place selected for operation until the slin was red, then scratehed with a sharp instrument, and laid upon it cotton soalied in the variolous pus, moistened with water from the sacred Ganges. Along with this measure they insisted upon careful hyerienic regulatious, to which, in large measure, their good results were due. Among the Chinese was practiced what was known as "pock-sowing," and ten centuries belore Christ the Celestials introduced into the nasal cavities of young children pledgets of cotton saturated with variolous pus. 'The Arabians inoculated with needles, and so did the Circassians, while in North Africa incisions were made between the fingers, and among some of the negroes inoculation was performed in or upon the nose. In Constantinople, under the Greeks, the custom had long been naturalized, and was practiced by old women, instructed in the art, who regarded it as a revelation of Saint Mary. The first accomnts of this practice were given to the Royal Socicty by 'Timoni, a physician of Constantinople, in 1714. The actual introduction of the practice into the West, howerer, was due to Iady Mary Wortley Montagn, who died in 1762, and who was wife of the English Ambassador to the l'orte in 1717. She 
had her son inoculated in ('onstantinople, by Maitland, and on her retum to London, in 172l, her daughter also was inoculated. Duringr the same years experiments were undertaken by Maitland upon criminals, and, as these turned out fatrorably, the Prince of Wales and his sisters were inoculated by Mead. 'The practice was then more or less speedily adopted on this side of the Atlantic, but suffered occisional severe blows, becanse of unfortunate cases here and there, such as never can be aroided. The clergy, especially, using the Scripture, as designing men can always do, becime warm opponents of the practice, and stigmatized it as an atrocions invasion of the divine prerogative. Nerertheless, in $17+6$ the Bishop of Worcester recommended it from the pulpit, established louses for inoculation, and thus mate it again popular. In Germany it was generally favored, and a little later came into vogne in France and Italy. In 1757 Robert Sutton, near London, professed to have made fifteen thousand inoculations without a single fatal case; he kept his patients on a strict diet for nine days, then inoculated with the smallest possible quantity of virus. The operation was not prolibited in England until the year 1840 , although it involved much greater dangers than raccination with cow-pox.

The first inoculation with cow-pox seems to have been performed in $17 i t$ by a farmer of Gloucester, named Jesty, thongh the pioneer in the extensive and general introduction of this method was Edward Jemner (1749-1823), of Berkeley, in Gloncestershire. who, therefore, is generally known as the "Father of Taccination." The son of a clergyman, he began early the study of medicine and surgery, and during his apprenticeship received from a milkmatid information of the protective power of cow-pox against variola, as established by popular observation. (Sutton and others had proved that inoculation of sheep-pox was not efficient.) This communication so struck Jenner as a means of affording protection to the whole human 
race that the subject never afterward loft his miml. In 1770 he became a pupil of John JImtes, atur whom lus communicated to him this idea the rreat smregon satid: "Do not think; investigate!" Aceordingly lue went to Berkeley and performed the little operation whirh has made him famous; and from 1778 mitil 1788 he communieated to Sir Everard Ilome such observations as he hat made. But the first vaccination was performed in 1796 ,

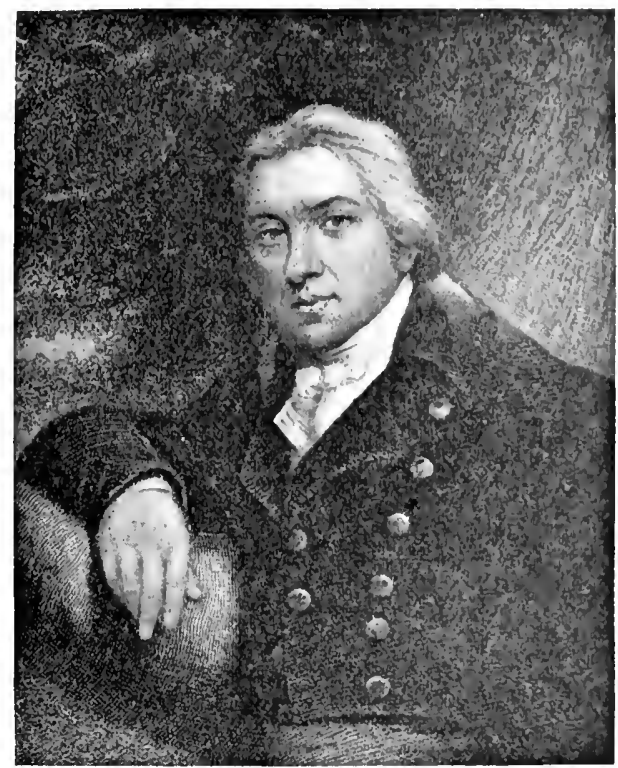

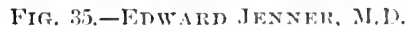

(From a steel engraving by E. Suriven made from a luinting ly J. R smith.)

upon a boy, with matter from the hand of a maid who had contracted cow-pox in milking. Tn 1798 he published his memorable work, and afterward remored to 1 condon. 1le died full of fame and honor, in his native place, having received rewards from the government anominting to one hundred and fifty thousand dollars. besides being made an honorary citizen of the city of London. The subsequent wide-spread practice of the methocl, and the formation of 
socicties for the promotion of vaccination are matters of recent history.

'The first raccinations in the United States were performed by 1)octor Waterhouse, Mrofessor of Medicine in Harvard College, in 1800 , upon four of his own children. 'The transmission of humanized virus through the system of the cow, and its subsequent employment in raccination of hmman beings, was first practiced by 'Troja (17t7-1827), of Naples, shortly after the introduction of human vaccination; but in 1810 this was prohibited in Italy. Compulsory raccination was first extensively introduced in Germany in $180 \%$; in England it was first legalized in 1827. The occasional temporary character of the protection thus afforded was first tunght by Elsässer in 1814. Schoenlein was the first to call attention to the distinction between variola and rarioloid.

Another matter in which the eighteenth century witnessed great reform was the treatment of the insane, which continued in very bad condition mutil toward the close of the century, when a movement for improvement began. From and after this lunaties were liberated from their fetters and from the hands of brutal heepers, and regarded as actually ill, while so-called schools of psychiatry were founded. While the first impulse in this direction was given by Lorry, the true reformer was Pinel, already mentioned, who did away with corporeal punishment and abuse, separated the insane from convicts, limited the employment of drugs and especially venesection, placed the unfortunates in special institntions under the charge of physicians, and elassified patients according to their symptoms. Iet, in spite of his humane teachings, lunatics were found incarcerated in cages in some of the French cities as late as 1834. Pinel was followed by Esquirol (1772-1840), who in 1818 established the first clinie for mental diseases.

It is well known what a conspicuous part public baths played in the social life of the ancient Greeks and Romans, 
but the first public resort for sea-bathing was ostablinhor in Germany in 1794. 'lhe cold-water epoch of this rentury, however, began with the researches of Halnu (l6igli1773), a Silesian, who introduced a systematic and almont exclusive hydrotherapentic method. 'The morlem mefhod of using cold water as an antipyetic agront wats first cmployed in England, in 1797, by (Mmre, who oricrinally wats an American merchant. In France the method fonmel little sympathy, but it made its way even to spain lator, where it was adopted hy the famous Simgrado, who is well known to readers of Gil Blus. 


\section{('IIAP'TER IX.}

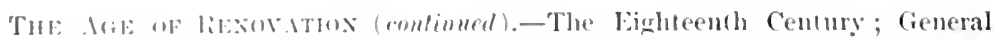

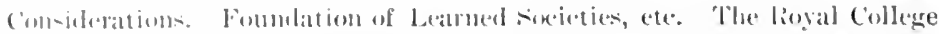

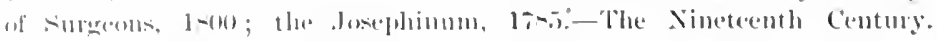

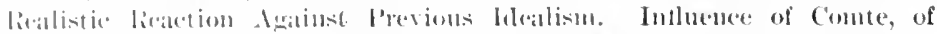

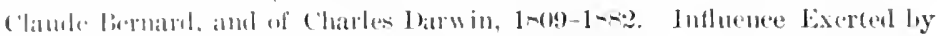

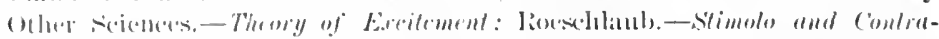

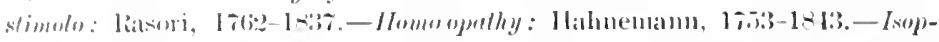

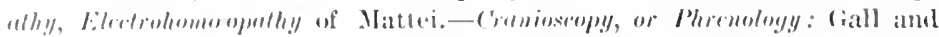

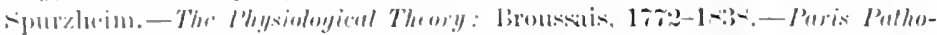

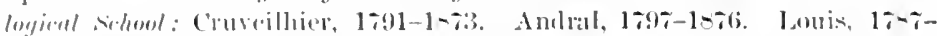

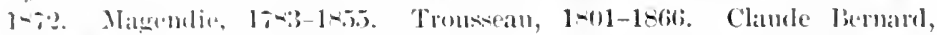

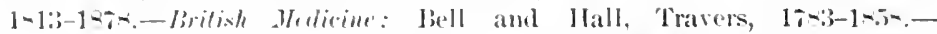

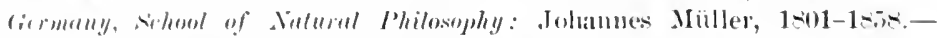

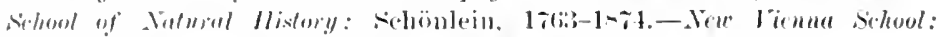

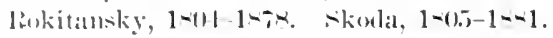

'Inat the eighteenth century, up to its close, was the grolden age of medicine, is due to the prevalence during that period of a strong idealistic undertone, as a result of which any learned occupation caused the scholar to be held in higher entecm than is the case even to-day. Medicine was then regarded as a conscientious rocution and not as a mere business or trade; indeed. general scientific knowledge more widely prevailed among the better class of the profession, and there was much less of that one-sided, narrow education that obtains to-day. The profession, moreover, was not overcrowded; physicians were neither too few nor too numerous, consequently their social position was higher. Again, the relations between doctor and patient were more intimate, most practitioners being of the type described as "fimily phrsicians," and those possessed of the doctorate degree ranked among the gentry rather than as artisans. 'They were, for the most part, finly devoted to their calling; moreorer, the State took greater care to protect the people, so that it became dangerous for strolling vagabonds and imposters to attempt to trifle with human life and excite the rulgar to the prejudice of scientific knowledge. $(2: 30)$ 


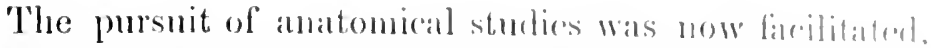
despite the fact that students were frequently compundhol to take long journeys in order to ohtain the "material" therr. for. In the early part of the century so greal was fhe bark of dissecting material that the great llaller while in l'arie

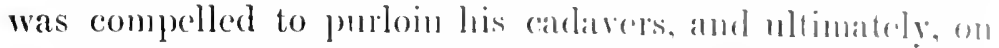
discovery of this fact, to fly for his life; Hoffmann was only able to make twenty dissections during fwenty-lour youla; even in the middle of the century there was only onc dissection anmully in Halle: "1] to 1712 there had ixen only three dissections in a seore of yours-thomgh now sulpjects can be had there in abmudauce at a ridiculously low figme; cadavers were extremely scauce in Viemuas late as litoi); and for a long time the only places in l,omdon where the study of anatomy could be legally pursued were the Colloge of Pliysicians and the College of Surgeons, and the tromble that hampered John Hunter in this direction is historical. The crime of "Burking" became known in Huntor's day. Murder was committed, and the victim sold for purposes of dissection-for at this time, as "body-snatching" was a necessity, those that purchased cadavers asked few questions, and the fees paid were, of comse, high.

The first clinical institution in Austria was organized in Viema, in 1754, by Tan Swieten, thongh there was an "ambulatory clinic" (ont-patient department) in l'ragrue nine years before. During the contury, however, hospitals were everywhere in bad condition. In the Ilotel-I)ien, at Paris, several patients-even as many as six-were sometimes put in the same bed; the convalesecut and the dying found themselves thus associated; in Viemna the Allgemeines Krankenhaus was composed of seventeen liospitals that subsequently were amalgamated into one. In I ondon numerous hospitals were founded, and as the medical staft of each became eminent they attracted numerous pupils; but later it became necessary to relieve the hospital wards, and private institutions for instruction were established by 
popular teachers. the most celebrated being the " Windmill Strect School of Anatomy," founded by William Hunter about 1770, and the private school of Sir William Blizzard, which, established in 1780, developed, five years later, into the I ondon Hospital Medical School.

While few, if any, of the lectures were compulsory, particularly in the natural sciences, even more attention than now was bestowed upon the accessory branches; botany, chemistry, and natural history were the recreation of many students and physicians. Pupils enjoyed the privilege of studying what they pleased-as they do practically to-day in the Portuguese University of Coimbra,-and professors exercised to the utmost their individuality in teaching. In Spain natmal sciences fomnd 110 admission, and eren so late as 1770 no instruction in these branches was given, as they were regareled as dangerous to the purity of the faith; mineralogr for mining purposes was an exception, for eren the most faithiul ('atholic needs money.

At the universities medical students were not permitted to go out without their scholastic cloalis, - a regulation that still obtains in Spain. That the number of students has enormonsly multiplied may be seen from the fact that the little University of Giessen, with scarcely any medical school at all, has always more students than had I Falle in the days of the famous Hoffmann. In the midelle of the last century Würzburg had at one time but three medical students, while to-day it has in the neighborhood of five hundred. Even then it was complained that, on account of the number of students, there was an educated proletariat arising, and in 1791 it was proposed, in Austria, that the rush for study should be repressed.

Among the Continental students the revels and bad behavior of past centuries were not to any great extent corrected; fights and debanchery were rery common, and all sorts of orgies and bacchanals prevailed. The professors were. in large measure, independent of the State, and 
a single individual often represented a number of hanches now tanght by special chairs. When indisposed to leeture, they simply posted upon the blackboard: "Ilorlie mon legitur," and this was the end of the matter. In 17 it Viemla had one hundred and forty-seven medical teachers, and in Germany there were two to every thirty-nine students. That in the last century one man often accomplished more than a great number of average teachers to to-day is amply demonstrated ly the lives of Boerhative, Haller, and others. Then, too, the latin tongrue was generally employed for purposes of instruction, though surgeons, for the most part, lectured in the vernacular; Cullen, in 1770, was the first in Great Britain to deliver purcly medical lectures in English; and as the clergy gradually retired from the ranks of the profession, latin more and more fell into disuse. Strange to say, as the clerical influence waned, the Jews began to enter medicine, the movement beginning about 1791, in France, under the promulgation of "civil equality" ideas; previously the Hebrews had been an almost miversally suppressed people, and in Berlin were permitted to enter and leave the city by only one gate, and were forbidden to leam or write pure German, in consequence whereof their dialect was an Hebraic-Tentonic jargon, that even to-daiy prevails in some portions of western Europe. Educated Jews were few in number, since attendance upon universities was ordinarily denied them, atthongh long belore they hat been admitted at Salamanca, Toledo. Salermum, and Montpellier. In Austria the prohibition was not removed until 1789 , and even then, so bitter was the prejudice against the somitic race, the elergy vigorously protested. It was the same clerical body that, in $166 \%$, protested with the erreatest vehemence against allowing IIebrew plissicians to pass through the gates of Würtemburg without paring toll, declaring that it was "better to die with Christ than be cured by Jews, who were aided by the deril." 
Professors were often attached to the courts of their valions sorerejgres, and at one time the French court possessed a liaculty of forty-eight physicians, surgeous, and apothearies, the first two physicians being required to attend erery morning when the king arose; hence originated the titles. still known in Germany, of "Jlofrath" and "Gohcimmith."

Malical fees, as a rule, were rery small, thougl, there were exceptional instances in which enormous sums were hestowed: Joseph II, of Austria, wave Guériu, who was smmmoned from Paris in consultation, an honorarium of 171,000 marks and made him a baronet. 'Taking all things into consideration. the income of the average practitioner in the eighteenth century would be in the neighborhood of $\$ 1000$, which, howerer, was equivalent to thee times that amount to-day. Fothergill, whose highest income in a single year was $\$ 25,000$, bequeathed to the poor of London $\$ 1,000,000$; Sir Astley Cooper had a yearly income of from $\$ 5.000$ to $\$ 100,000$, but it may be remembered that his practice during the first year netted him just $\$ 26$, and that it was four years later before his income reached the sum of $\$ 500$.

'The physician of the last century was, at least, on occisions of moment, very different from other men, and to be recognized by his dress. A (ap) was placed upon his head when he graduated, in recognition of the fact that physicians at an carlier period belonged to the learned or clerical profession; and in later life he wore a purplish or searlet cloak (to distinguish him from lawyers, whose professional color was yellow, and from theologians, who then, as now, sported the sombre black). The regulation fulldress costume of the English physician of the last century demanded a well-powdered wig, silk coat, knee breechos with stockings, buckled shoes, lace ruffles, cap, and goldhearled cane, to which, in cold weather, was added a muff - to preserve his delicacy of touch. 
Surgeons were still strictly separated from physicialm, even in education; nor were they esteremerl as explal in rank, until the French Revolution brought about the dortrine of civil equality ; perhaps this is once reason why this

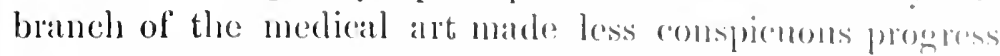
until recent times. 'The rhange was hought albont, in Fiance, by the abolition of eighteen muiversities and fiftern colleges of medicine, the Royal Societ y of Merlicinn (fommolod in 1776), and the Academy of Simgery (fommed in 1731); but by this abolition rhathatanism acepured surele speredy control that the arrangement was soon abandoned. 'l'hus it came about that surgical instruction was giron in sperial institutions or in the universities, and the conditions of instruction finally improved. When the collowe of st. Côme was abolished in 1753 the Société de Chirurerie, foumded in 1731, became the Academie de Chimmorir: and, when the French Academy was formed in 1795, the Académie was merged into its medical department. 'l'he Ecole Pratique, where Desault and ('hopart tanght, was established in 1750 for the practical education of surecons. In England the Royal College of Surgeons was net incorporated until 1800). In Austria, in 1785, the Josephinum was opened by Joseph II, who also erected permancut military lospitals in Prague, Brimu, Milan, Mantua, l'estl, Olmïtz, etc.; he also created the "Joseph's Aliademic" in order to educate military surgeons aud thus orercome the defects of army surgery; the Josephinum unquestionably exerted great influence in elevating the social and military position of army surgeons and attained historical importance after Brambilla compelled the recosnition of surgeous as social equals of other members of the medical profession. As the result of these improrements, the rarious armies of Emope were soon furnished with better medical officers. Prior to this, too, the field hospitals had been as bally mismanaged as their ciril prototypes, and the substitution, in 1793 , of morable hospitals, as sug- 
grested at the close of the sixtecuth century ly Henry IV, of Fince, was scancely an improvement. J'he whole system suffered from perpetuation of the dual and distinct functions of the plusician and the surgeon. to destroy which was a part of the design of the Josephinum. How muleasant was the position of the army surgeon up to this date may be infered from the finct that in 1758 one was subjerted to corporeal punishment at the command of his coloncl, and that a general upon his death-bed could leave orders that fifty blows be given each of his medical staff in case the post-mortem disproved the diagnosis.

In Austria, at the beginning of the Seven Years' Mar, all military surgeons of the P'rotestant faith were compelled to become Catholics or leave the service. The condition of the wounded soldiers was as deplorable as can well be imagined; but upou this subject I cannot dwell.

The tendency of the nineteenth century seems to be a contimuation, and, perhaps, in some respects, an exaggeration, of the condition obtaining in France during the previous century; in other words, the world has become practically an enormous school of pathological anatomy and diagnosis, - a school inaugurated by Bichat, as representing so-called scientific or exact medicine. Philosophically this has been a century of reaction against the idealism of the preceding age; it places the individual, rather than the idea, in the foreground. The mutual influence of medicine, philosophy, and the natmal sciences is less conspicnous now than formerly. Recent philosophers who have exereised the greatest influence are: Schelling, who held to the equality of the real and the ideal; Ilegel, whose supreme principle was absolute reason, of which religion was regarded as a representation; Hartmann, whose philosophy of the "unconscious" depends largely upon the results of natural sciences, embraces Darwinism, and is, in many respects, an extension and completion of 
Sehopenhaner's pessimism and doctrine of the sonl. lint one who has exercised still more influence upon onr profession is Comte, whose positivism contrasted strongly with the idealism and atheism of Schelling, and who repuired only this of philosophy,-namely, that it slrould worli ont the general ideas and results of other sciences; his most important follower was Claude brernard, and upon threse two the whole exact school of liance is based. lint the most influential philosophic doctrines of this or any other century have been those emanating from (harles Darwin, Herbert Spencer, Ernst Hacekel, Alfied Wallace, and their contemporaries and followers. Jirwin (1809-1852) was the grandson of Erasmus Darwin, already mentioned, and his Trariation of Animals and Plants Under J)omestication, Origin of Species, and Descent of Men have found a place in all modern langnages. 'The system known by his name is the pure seience of nature, is founded upon scientific investigation, and by its merits alone has found almost universal acceptance; it has been added to and further elucidated by the efforts of Haeckel and Spencer.

When it is declared that medicine of the present is influenced by no system, it is speedily found, on critical analysis, that this is an error. It necessarily follows the realistic and materialistic as readily as it did the teachings and doctrines of natural philosophy; and, in consequence, "medical thought," so called, is just as one-sided to-day as at any time in the history of the art. The watchword of to-day, "natural specific tendency," veils, but does not take away, its philosophic principles, and so our ridicule of earlier nedical systems is quite unjustifiable. A modern historian aptly remarks that the medicine of the present "embraces nothing but a theorem of investigation by the senses."

Discoveries in botany, the result of better knowledge of natural listory and more accurate habits of study, have 
influenced modern progress not a little; have led to better classification and broaler knowledge. 'The natural system of de C'andolle (175-18+1), of Genera, and of Endlicher, of Vienna, called into existence the so-called natural historical school of medicine; the researches into plant-cells by schleiden and Baumgintner, and the almost contemporaneous discovery of amimal cells by Schwann became, in comse of time, the origin of recent cellular pathology; then eame microscopic botany, and the influence of the lower fungi in the production of fermentation and putrefaction.

similarly, too, the laws of physics liave been shown to have an inseparable connection with anatomy and physiologr, and their study luas become a most important aid in the experimental researches of to-day; through Helmholz they brought in the ophthalmoscope; thermal electricity, for the discovery of which medicine is indebted to Seebeck; a better linowledge of opties, thanks to Framhofer, who was equally expert in electrieity; spectrum analysis, invented by Kirchloff; and the raried efforts of Faraday, Graham Bell. 'Thomas Alva Edison, and Daguere, the latter better known for his invention of photography. Finally, medicine is immeasurably indebted to 'Tyndall and Huxley for their teaching of the correlation and conservation of energr.

Chemistry also has performed its share, and, as applied to physiology, is a discovery almost wholly within the present century. The new nomenclature serres a practical purpose in that it is now possible to portray chemical combinations and isomerism in a graphic, and, at least, semicomprehensive way. Among the chemists may be specially mentioned Bertholet, whose laws are as well known as they are succinet; Humboldt; Berzelius; Dumas; Chevreuil, who recently died at the age of almost one hundred years; Magrendie; Orfila, the toxicologist; Gmelin, eminent in physiological chemistry ; Rose, perfecter of organic anal- 
ysis; Wölıler, who first made organic allallends; limusen; Sir Humphry Dary; Marsh; lataday; (iraham, Voumg, who first showed the industrial value of coal ; and cialyLussac.

Upon medicine, zoölogy also, with comparative anatomy and physiology, has had a wonderfin influenes here may be noted the names of C'uvier, Oken. Billatr, Birehur, Wagner, Leuckart, Richard Owen, William Carpenter, and last, but by no means least, 'I'homas Iluxley.

But perhaps the most significant frature of the age hals been the wonderful development of scientifis: ansoriations and the publication of medical and scientific literature. Whether these have yet reached their climax is perhaps an open question, but the consequent widening circle of readers, as well as of writers, seems to imply that them will be for a long time to come no lack of antivity in this direction. In the United States more than in any other comutry medical societies and associations innumerable have sprung up, and to such a degree that (in the castem States at least) there are few comntics that camot boast of a medical organization.

During the present century foreign universities hatse decreased in number, partly owing to consolidations and partly by surrender of charters; for instance, the old Lniversity of Ingolstadt was mited with that of I andshut, and in 1827 was removed to Munich; in 1816 the University of WÜrtemburg was united with that of Ilalle; the Lniversity of Bomn was abolished in $179 \%$, but revived in 1818 . A few new miversities, like that of Zärich. have been founded. In the quaint old town of Prasue the old German university was, in 1883, divided. and there now exist in that city two universities side by side, in one of which German is spoken, in the other Bohemian.

It will thus be seen that the ninetenth century is essentially an era of modern science, with whose dawn was sounded the death-knell of the "demon of discase" and his 
twin brother "risitation." In 1801 the first experiment in steam-1narigation took place upon the 'Thames. In 1807 the slave-trate in England was abolished by Parliament. The theological part has entively faded out of medicine; and the era of alcrurate scientific experimentation which long since dawned, is now, so far as we can see, at its hojght, since it is clifficult to conceive of much inuprovement upon its methods under existing conditions, or of greater enthusiasm than has been already manifested.

Now. regarding some of the systems and theories of this age. The systems of the past have been more or less longlived,-as, for instance, those of Dogmatism and of Gialen, -while as we come closer to the present they become more ephemeral. Those of the carly part of the present century took root in the soil of the eighteenth, - for instance, the so-called theory of excitement of Roeschlanb (1768-1835), which endeavored to mold into one the Brumonian errors and the funcies of Selielling. According to it, life depends upon irritability, but is inherent in the organism as an independent feature; so it recognizes both irritability and solidism, while 13rown considered the former alone, adding, as an after-thought, a chemical or qualitative potency (oxygen), in order to account for alterations of quality. Roeschlaub inclined first toward natural philosophy, then, owing to an inherent theological and polemical bias (he was originally intended for the church), to mysticism and theosophy; finally, with a courage almost mexampled, he upset all his former teachings by admitting he was mistaken. To him was opposed Hufeland, who wrote on the Lergthening of Life, was noted for a warm and benevolent heart, and possessed no small penetration, as is evidenced by his aphorism, "Snccessful treatment requires one-third science and two-thirds 'savoir faire." "

Stimolo and contrastimolo were titles applied to a theory advanced by Rasori (1762-1837), of Milan, that combined Methodism with Brunonism; by Baas it is char- 
acterized as a "gremuine blot mpon thr humatn hrant herond any other of the various systems." lane enturien of $r . x-$ perience and the comelusions of great and renemalu minds may go for langht, as Rasori abundantly dromonstralod. 'The theories of Brown were then tanght as his own to his classes in Pavia, showing he was not above placrialiems f his stimolo corresponded to the sthenice diathesis devisod hy Brown, while his system consisted of an endeator to malie? a diagnosis by watching the effects of drongs. IBlerding wis held to be the best measure; if it did the patient good, the sthenic diathesis was assmed; if it made him worse, the asthenic was certain. He gave enormous doses of powrerful drugs-sixty grains of gamboge, and fiom two to three ounces of saltpeter in a single day. Is it strange that homocopathy or any other heterodox system sulrang up in the midst of such measures? It is an old saving that there is no folly which will not secure a following; and, strange to say, Rasori had a mmerous and an eminent one.

As just intimated, Homocopathy was the natural reac'tion against such heroic measures; in the rebound the ofher extreme was reached, even to practical therapentic nihilism. Now, instead of venesection and drastic medication, came the theories expounded by IIahemann (1753-1843), which denied discase, admitting only symptoms. 'This apostle of homocopathy was the son of a porcelain-painter in Meissen; he studied in Leipzig and in Viemna, and later practiced in various cities, including Dresden and Iceiprig. "Simitiu simitibus curantur" was not original with him, as it long before had been formulated by Hippocrates, and later by Paracelsus. Of the life and labors of Halunemam, nuch might be told; but this is not the time or place to gro into the subject.

An offshoot of homcopathy, which demands only the harshest criticism, is Isopathy,-perhaps the filthiest theol'y ever invented, - according to which like is to be cured by 
like, and to such an extent that small-pox is to be treated by variolous pus, tape-worm by the ingestion of the proglotticles, etc.

Another of the rankest of fraudulent outgrowths is the so-called Electrohomøopathic system of Count Mattei, who prates of "red," "blue," and "green" electricity,-a theory that, in spite of its utter idiocy, has attracted a con-

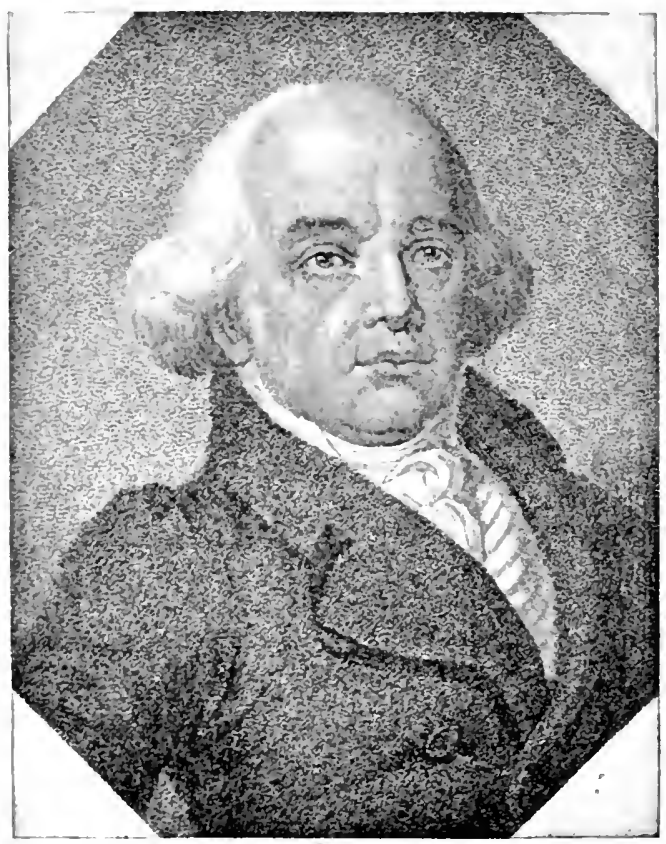

FIC. 36.-FAMUEI, HAHNEMAXX.

(From a steel engraving.)

silerable following and earned a fortune for its chief promoter.

Another of the vagaries of the earlier portion of the present century, and that still survires, in a weak way, is C'ranioscopy, or Phrenologry. Gall expounded his doctrines at Tienna as early as 1796 , but, being expelled, went to Germany, where he was joined by Spurzheim, who, though 
much more of a student and scientist, aceepted the doretrine of the former with enthusiasm; and it was chicfly dure fo the efforts of Spmzheim that phrenologry was introducent into England, and later (1832) into Amerien. (iall assumed to locate twenty-seven different organs alonemide of each other in the brain, and held that extrmal mankings on the skull were gruides to the development of the various parts. Every neophyte in anatomy linows low little foundation there is for such a doctrine, but for at time it attracted great attention, and there are torlaty certain men and women who make their living ont of this imposition.

'The Physiological Theory of Medicine was originaterl by Broussais (17\%2-1838), and combined the viows of Pinel and Bichat with the "sympathetic" view of 11 offmann, the "concealed inflammation" of Stoll, and thr" theory of inflammation held by Mareus. Broussais had been a pupil of Bichat. In 1814 he began hospital teaching, and in 1831 was made professor. l'ersonally very vain, quick-tempered, even belligerent, as a therapentist he was a man of routine. He was, perhaps, bent known shortly before his death, when delivering lectures on phrenology. According to him, life depends mpon external irritation, produced by heat, which excites new chemical processes, while these in turn stimulate reconeration, assimilation, as well as contractility, and sensibility. When the functions supported by heat cease, death cusues. Health depends upoin moderate action of external irritants; disease, upon either their weakness or their extraordinary strength. He saw nothing ontological abont disease. In therapentics he admitted the healing powel of Nature, but regarded the physician not as a minister. but as a lord of Nature. Febrile and inflammatory diseases were all treated by the withdrawal of nomrishment. carried to the extreme. His most powerful antiphlogristic treatment consisted in the application of leeches to the 
abdomen, and to robust individuals he applied from thirty to fifty at once It is not, then, to be wondered at that, in consequence of his so-called "hirudinomania," leeches became very scarce In the year 1833 forty-one million five hundred thousand lecehes were imported into France, while in 1524 one-twenticth of this number sufficed to supply the demand. Even in cases of worms, the abdominal integnment had to pay its blood-tribute, particularly if enteritis prevailed. He only allowed a spare diet of mucilaginous and acid drinks. In mercurial France and Italy he gained numerons followers, but they were few and far between in practical, hard-headed Germany and Eugland. His best follower was Bonilland (1797-1851), who adopted the symptomatic nature of ferer and the sangunary therapentics of his master, but used the lancet more than the leech. As the homoopaths regard Hahnemann, so Bonillaud looked $u$, to Broussais as the Messiah of medicine and science. which, as Baas saỵs, were "already greatly overstocked with Messiahs."

Contemporaneous with the school of Broussais, and its antagonist in all respects, was the Paris School of Pathological Anatomy and Diagnosis, which has given tone to all medical art. It made it the duty of the physician to search for clanges in the luman body, to investigate the local products of disease, and assigned to medicine the duty of removing these products. The tendency of its teaching was to treat the patient rather as a living cadaver than as a sentient being endowed with rital forces, and the charge which Asclepiades once falscly made against Hippocrates was revired upon new grounds. Kratzmann wrote some years ago: "In France cvery one experiments on the sick, less to attain the best method of cure than to enrich science with an interesting discovery and to advance the accuracy of diagnosis by some new phrisical sign." The seductiveness of this system promoted still more onesidedness, which finally almost attained the belief that the 
science of medicine really originater in the Anatominal School of Paris.

The forermmers of this school were litehat and l'imel, and its proper foumders were (Corvisal, l)mpurtren, and lä̈mnec. 'There was also biayle, who wats first to illyly the ear to the thorax in discase of the lunat, and thes

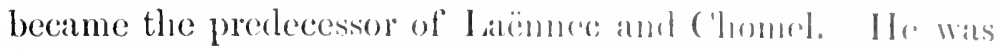
the godfather of typhoirl ferer, and frem lwing a limons clinician became later a great pathologrint. 'l'he most celebrated adherent of the methesl, howerer, was ('mropilhier (1791-1873), prolessor first in Montuellier and then in Paris, who revived the Anatomical Soredy lommed by Bichat, and wrote his first essays as the result of I )upmrtren's advice; finally, there came from his pent the linmons treatise on P'uthological Amotomy, with its mannifirent plates, - a work begun in 18.30 and not fully completerl until 186t. Like Morgagni, he associated general amel pathological anatomy with bedsicle observations; alho established a class of inflammations to which belong gangrene and atony, and a certain class of nemroses and ferers, and endearored to investigate the different steps in the development of lesions, not simply their final produrets. Ilis teachings concerning promia and phlehitis, which hat been first studied by John IIunter, excited preat altention, and he even came to the one-siden comelusion that "phlebitis rules the whole of pathologr." He was the first to observe that its suppurative form does not occur primarily, but is secondary to coagulation of the blood.

'The ablest representative of this school. and one who, perhaps, more than any other man, male l'aris a Mrecal to which foreigners made their pilerimages. was Andral (1797-1876),-the son of a physician and the most noted and indefatigable investigator and thinker of his time. Between 1823 and 1840 were published the fire rolumes of his Merlical Climic, which made him fumous. He taught, in opposition to Broussais, the existruce of primary 
diseases of the blood. the so-ailled dyscrasice; made physiology subservient to pathologry was the creator of the chemistry of the bloud; and in therapentics was weelded to emetics and cathartics, ascribing little inportance to abstraction of blood.

'The first man to apply the Numerical Method to pathologrg and who bromght about the downlall of Broussalis, was I but came to Paris while still a young man. He expressed his principle in the following words: "As olten as I have formed an " mimi idea and had alterward opportmity to prove the facts, I have invariably found that my idea was false. In pathology as well as in therapentics numerical analysis is a useful practice. By mumbers only cau be obtained the frequency of conditions or this or that symptom; by a definite enumeration alone is it possible to ntilize the special relations of age, sex, constitution of our patients, to settle that this ol that srmptom ocenrs so olten in one hundred or one thousand calses." 'This system he applied to etiology, symptomatology, prognosis, therapentics, and pathological anatomy. Ile discarded blisters and condemued large bleedings, but fell into other errors, carying his numerical method to an mujustifiable extreme.

Next to Andral and louis should be mentioned Magendie (1783-1855), Prolessor of General Pathology in the College de France, and physsician to the Hotel-Dien, who was a representative of the new French medicine, and introduced experiments into both pathology and phrsiology; he was the pioneer in experimental pharmacodynamics, which occupies itself largely with alkalies, a large number of which he introduced into practice. He was a solid humoralist in pathology, a most accurate diagnostician, but (it is charged) "was too simple in therapeutics"! As a result of his intravenous injections of putrefactive material, he had the terms "pyiemia," "ichorrhæmia," and "metastasis" introduced into pathology. 


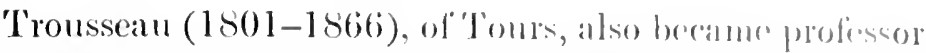
in the Paris Faculty, and rendered enperial sorvice in his studies of cromp and the cmployment therefor of tratheotomy, though his chief fame rests 11 pon lis morit als it clinical teacher and the publication of clinical lerefures which are still models in crery way of accurate, forrible teaching.

Claude Bemard (1813-1878) horame the surecessod of Magendie, and even mole limmons as an experimentre in pathology, physiology, and anatomy. Origrinally a prot, he

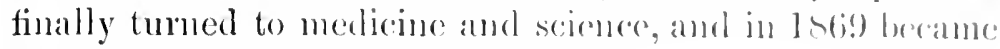
a member of the French Academy.

Oue of the results of the Fiench fombuess for gattionlogical anatomy was an ontergowth, mulortumate in some respects, of specialism, which male its appeatrance cally

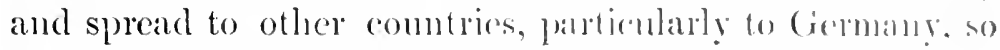
that to-day there is sorrecly an orean in the body which has not only its special student, but jts special repuesentative in medicine. It would be of interest to aro orel some of the various organs and romut those who have become most renowned in the study of their discases, but that is beyoud the scope of this volume.

As Baas says, England, alter her cxcessive partiojplion in the iatrochemistry and iatromselandes of the serenteenth century, with a derotion that extonded far into the eighteenth, seemed then to lose all confidence in sytoms and schools of medicine, inasmuch as since that time no) system or so-called school has gained in Giseat bitalin any large or permanent band of followers; cren Prmonianism did not suceed in this respect. This form of conservation is a characteristic of the Jritish race. But while shools have not risen, individuals lave formulated hypothenes or doctrines that at loast attracted attention, if not followers. For instance, Joln Mason Goode (1764-182i) formulated an intricate nosological amangement in his long-popular text-book entitled The Stul!! of Wrdicine, 
and also arranged a classification of discases now almost forgottern.

In 1516 sil Charles Bell (177t-1842) made the memorable discovery that the posterior roots of the spinal nerres preside orer sensation, and the anterior over motion; and this attracted anew the attention of English physicians to the nerrous sritem, and was rewarded by the later discovery of reflex action or reflex phenomena. communicated to the Royal Society in 1863 ly Marshall Iall. Both discoveries were important, and both were duly rewarded by get others.

Benjamin Travers (1 $75.3-1858$ ) seems to have been areatly influenced by the first of these discoreries, and led thereby to pay special attention to what he termed "constitutional irritation"; his studies on this subject are often quoted to-day, and are well worthy of perusal; he understood by this term a process (in strong contrast with inflammation) which subsides without hyperamia and without plastic exudate, but which, on the other hand, may occasion liquid products and result in neoplasms.

Contemporaries of 'Travers were: Abram Colles; John Cheyne (1777-1830), of Dublin, who wrote on Diserses of Childien and described "Cheyne-Stokes respiration"; William Stokes (180t-1578), also of Dublin, who distingnished himself in 1857 by a great work, entitled $A$ Tireatise on the Diugnosis and Treatment of Diseases of the Chest; Robert Graves (1797-1853), Professor of Medicine in the King's and Queen's College, Dublin, who mublished clinical lectures of his own, besides many clinical reports in connection with Stokes. Graves was one of the first to oppose the "absolute diet" of the earlier physicians in the management of febrile maladies, and requested that his epitiph should have but one line-" He fed fevers!"

"The School of Natural Philosophy" was the title applied to a system which, in Germany, ran parallel with that of Broussais, being the legitimate outcome of the 
medical philosoplyy of the cighteroth exulury which hat originated there, and also a revival of opposition thereto on the side of realism. It led into speculative extremes. which finally sobered down, becamse of the momingless sebolature phrases often introduced, and thus bolie a path for the subsequent enthusiasm in behalf of french positivism in medieine. 'Those who comstiluted this school wore, for the most part, men of importance, but were followed by a number of imbecile representatires. Lo was made of the abstract doetrine of the philosephly of identity and the imponderables, such as electricity, mechanical foreres, and magnetism, contrasted with which were the dimensions of matter and certain qualities, like sensilsility, initability, ete. Perhaps the greatest influence of this tealching was in the department of embryology and physiology, where Johames Miiller displayed his remarkable activity. Among the most distinguished representatives of the natural-philosophy school was Oken (1779-1851), of Baviria, who subsequently taught in Munich, Jena, and /iürich, and published a large work on natural history, which did much for the popularization of this science; he explained that the sliull is made up from a series of rertebre; also discovered the Wolffian bodies, and was such a power in his way that Agassiz characterized him not only as "a master in the ant of teaching," but as "a comrageons and ruling spirit." Others of this school were: von Walther (1782-1849), eminent as a surgeon; Dollinger (1770-1841), of Bamberg, the distinguished leader of the Old Catholics; Reil and Prochaska, anatomists; Troxler and Schelling, philosophers and anatomists; 'Treviramus, the microscopist; Malfatti, Kilian, Spindler; Schmidt, of Vicuna; and others too numerous to mention.

As a successor to the School of Natural Philosophy came the School of Natural History (1831-1850), which made important concessions to realism; its most prominent members were from South Germany. This school was 
based partially upon the pliilosophy of Nature, and expired almost suddeuly. One of its most eminent exponents was Krukenberg, whose therapentic creed was that "Physicians should be filled with pious reverence toward Nature; the organism is a whole, and must be contemplated in this sense; medical art is, undoubtedly, capable of decisive action, but let us not mistake that in many cases its activity is quite superfluous, in very many null and inadequate, and in many injurious." 'This school was the expression of the tum medicine was compelled to take in order to escape the after-effects of the one-sided, ideal, systematizing tendency of the eighteenth century (whose final outcome was natural philosophy), and to square itself with the realism and positivism of the nineteenth.

Schönlein (1763-1S 7 ), of Bamberg, outlined a system that taught pathological and anatomical revelations as concrete expressions of the independent entity disease, whose relation to the organism is as that of a parasite sojourning temporarily in it; he also constructed a classification of discases, something after the manner of the botanical classification of de Candolle. One of his best-known pupils was Canstadt (1807-1850), whose Juhresbericht has preserved his name. Siebert, of Jena, famous as a diagnostician, and Hacser, the medical historian, belonged to this school.

An offshoot of the French school of pathological anatomy and diannosis was the so-called New Viemna School, which aided the French system in obtaining high recognition in German medicine, and gained its first influence firom the labors of Wunderlich (1815-1857); next to whom should be mentioned Baron von Rolitansky (1804-1878), - a Bolıemian,- - one of the most famous men in modern times, and who exercised a profound influence, even in foreign countries,-particularly in Italy and Russia. Ton Rokitansky worked for a long time in miserable quarters in Vienna, but finally a magnificent building 
was specially crected for him. He was loakded with hourors, and took his seat in the Austrian Homse of' bepultes. 'I'wo sons are well known in mediegne fo-elily, and fwo mone have achicved reputation as singers, - a rimomstanee which the father embodied in the bon mol that "two of his sons howled and two of them lealeel." Ile transplanted into Viema the tendency of the earliost pathologicomonntomical school, which captivated all hy its novolty and interest, and in the post-mortem room and the cliniral-lecture room ho converted merlicine in Germany to the realism of the nineteenth century. Ile was, indeed, the Van Swiofon of his time in his influence mon educational affairs. Ilis works

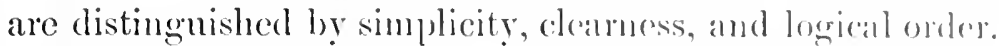
He performed more than thirty thousand antopesios; for fourtecn years he studied the deferts of the septum of the heart and the companative anatomy of the uterns and genito-urinary organs, yet paid little attention to the microscope or to applied medicine. He was a pathologist, pure and simple.

A friend and co-laborer,-Skoda (18()3-1881),-also a Bohemian, was little, if any, less famous. In 1839) he gave to the workd his famous work on Aluscultution uml Percussion; in 1847 became professor at l'ragne, and wis the first man to lectme in German. In spite of his bachelor peculiarities, his tacitmmity, and his heerllessness, he was very popular, and left a fortume,-quite in contrast to Rokitansky, who died poor. I I is seientific merit was hatsed upon the fact that he overthrow the specitic and pathoguomonic amangement of somds, as tanght by the French, and substituted therefor a category, hased npon the plysical constitution aud shape of organs and tissues. He endearored to develop a strictly scientific sristem of physies out of the empirical French doctrine of physical signs, and in his work on Physical Diugnosis he displayed an independent spirit, though as one who had received his impulse firom France. He was the first in Germany to insist upon the 
merits of Arenbrugger, and was the leading diagnostician of his time of the new Viema sehool. Shoda was the first for whom was created, in Viemna, a specialty after the French molel, - that is, a special division for patients suffering from thoracic discases. Great as he was, we must yet lay it up anginst him that throngh his influence,-first in Viemna and afterward thronghont Germany,-practical medicine degenerated into simple diagnosis, and that, by his observations on the natumal course of disease, undisturbed by therapentics, he became the founder and exponent of expectant or nihilistic therapenties, - the harbinger of a very checrless period in the history of medicine. 


\section{('HAPTER X.}

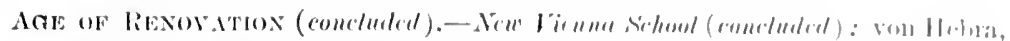

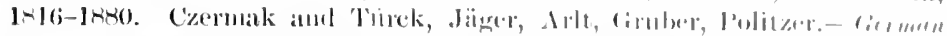

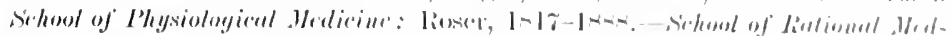

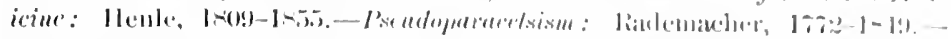

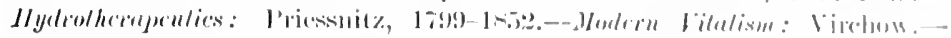

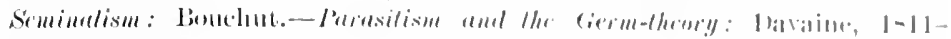

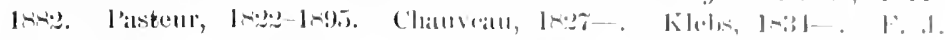

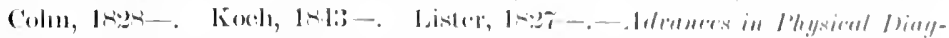

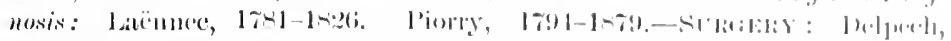

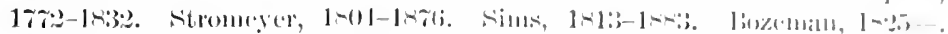

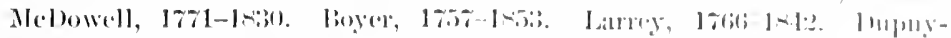

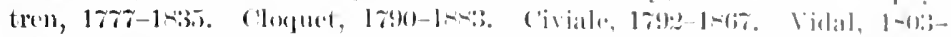

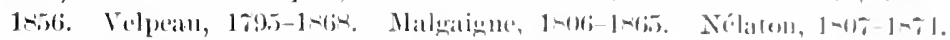

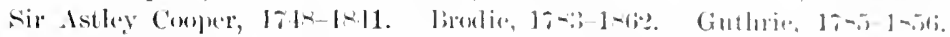

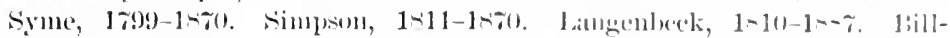
roth, $1819-1-91$.

A rew of Skoda's more aminent colleagnes descrve brief mention: Oppolzor (1808-1871) was singularly wifted in diagnosis, popular, a taacher of wide influcnec, and manifested in superlative degree the characteristies that constitute a great physician; he wrote little, but was for a long time Professor of Medicine at l'agne. Ton IJchra, the elder (1816-18\$0), worked a complete revolution in dermatology, and developed a classification based upon the pathological anatomy of the skin. He instituted a new and independent line of therapentics as applied to this branch of our art, for which the medical norld will ever hold him in grateful remembrance. Sigmund and \%oiss during the same period did much to char up the problems of syphilis. To Czermak (1S2S-1873) and 'lürck (1S071868) we are indebted (practically) lor the making a specialty of diseases of the nose and laryx; of like service to ophthalmology were Jäger, Giatefe, Arlt, Ntellwag, Donders, Hasner, Manthner, Fuchs, and ron liens, while Gruber and Politzer did as much for discases of the ear.

An indirect offsloot of the new Vienna school is the so-called "Physiological Medicine," founded by Roser 
(1817-1s8s), of Stuttgart (late Professor of Surgery in Marburgr), seconded by Griesinger and IVunderlich. 'Their views were directed anainst the symptomatologists and idcalists, and particularly against the School of Natural History, the claim being that physiologry must juclude vital phenomena, while firom the morbid portions of these phenomena the special seience should be formed as an artiticial, get practical, division of knowledge. Wunderlich's book of therapentices was for a long time the best gruide in this direction, inasmuch as it left to individual thought and julgment-the IIippocratic method of investigation-the determination of value and demand. Another offshoot, that differs but little from this save in definition, is the "School of Rational Medicine," originated by Pfenfer (1806-1869) and llenle (1809-1855), and which, since 1stl, has been represented by a special journal. While Winderlich claimed pathology to be the physiology of the sick, Henle considered this questionable and made no distinction at all between the physiology of the healthy and that of the ill. 'The language of the followers of this school contrasted strongly with that emanating from other schools, and for a time was confident and ingeniously trimmphant; nevertheless, it did not forget philosophical speculation, and Hegel may now be regarded as indirectly the godfather of rational medicine.

'The vagaries of Paracelsus led indireetly, though positively, to the fomdation of Ilomocopathy, and likewise originated the doctrine that bears the name of Rademacher (1772-1849). It is curious that this psendoparacelsic system should spring up alongside of the Vienna school, its teachings being the classification of diseases by their therapy. Rademacher's followers possessed three universal remedies,-“cubic niter (nitrate of sodium), copper, and iron,"-ind also three primary diseases that must take their titles from the three universal medicaments. In spite of the admission that these diseases were unknown, it was 
boldly asserted they were with eortainty to ho ended hy the three chief remedies. The three primary discases, "soclice nitrate, copper, and iron diseases," do not neressalpily remain as such, as they may throw seme organ "into a condition of sympathy, and thus it results that iron discance may express itself in the form of eomsmmptions, dolirimm tremens, etc., while a copper discase may appera as worms,

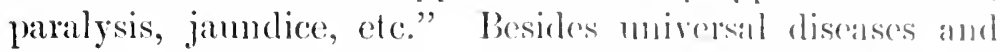
universal remedies there were diseases of oremans, to be diagnosed by the officacy of organ remedies; thus, abdominal diseases must be relieved by corresponding "abdominal remedies," head discases with "houd remedices," chent diseases with "chest remedies," ete. Also for "ach particular viseus there must be a special remody. That is the most surprising about this absurd doctrine is that it found followers, some even quite capable in their way.

Now, too, reappeared the Ilychotherapontic Srstemthe great apostle of which was Priessuitz (1799-1852)based upon gross views of humoral pathology, according to which a disease entity was to he expelled in the form of sweat, eruption, etc. Poultices, cold packs, and cold haths were the principal therapentic measures. Wintenity has made hydrotherapy popmlar and, in a measure, effective in the management of certain maladies.

Rudolph Virchow in 1858 instituted the doctrine or theory known as "Modern Vitalism." which, in fact, was borrowed from natmal scientific medicine, and distinguished from the ritalism of the previous century in that it breaks up the old rital foree, which was supposed to be either distributed throughout the entire body or located in a few organs, into an indefinite number of associate vital forces working harmoniously, and assigns to them all the final elementary principles withont microscopic seat. "Every animal principle has a sum of rital mnities. each of which bears all the chameteristics of life. 'The rharacteristics and mity of life camot be found in any deter- 
minate point of a higher organism,-e.g., in the brain,but only in the dofinite, ever-recurring amangement of each element present; hronce it results that the composition of a lare body amounts to a hind of social arrangement, in which ach one of the movements of individual existence is dependent mon the others, but in such a way that each element has a special activity of its own, and that each, although it receives the impulse to its own activity from other parts, still itself performs its own fiunctions." 'This is nothing but another way of expressing the cell-doctrine, to which many medical men ale now rommitted, which means that all bodies are built up of cells and that cach cell has a unity and a pmpose of its own.

In 1675 Sir Robert Hooke dincovered plant-cells; later Sehwam discovered animal cells and Robert Brown cellmuclei; but it remained for Virchow to supply the gap which hatd risen between anatomical knowledge and medical theory; that is, to supply a "cellular pathology," since which time the cell has assumed the role which the filme occupied in the theories of the seventeenth and eighteenth centuries. Time alone an decide as to the ultimate validity of this theory, which has in certain circles been most enthusiastically received. One of its weakest aspects is. perhaps, that the so-called intercellular substance plays an uncertain and mosatisfactory part. An important feature in which the cellular pathology differs from other systems, and particulary from the old humoral pathology, is in the doctrine that the blood itself is not the proper and original cause of dyserasiae, and probably not the cause of continuous alteration of the tissues; that these dyscrasia arise because the blood is not an independent structure, but dependent npon the condition of the patient in consequence of its continuous converance of the noxions material from all parts of the body,-the blood is, therefore, merely the medium for the production of the dyscrasia. This theory has made sereral peculiar, new, and symptomatic or mor- 
phological forms of discase, such as lenkiernia, lenrourytonic,

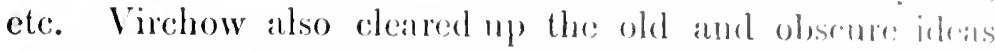
regarding pyamia, and proved that an absorphtion of pus into the blood, which the name implies, is quitr impossible; likewise, that pyemia is inseparable fiom thombletir processes.

Virchow was born in Pomerania in 1821 , and in 184!

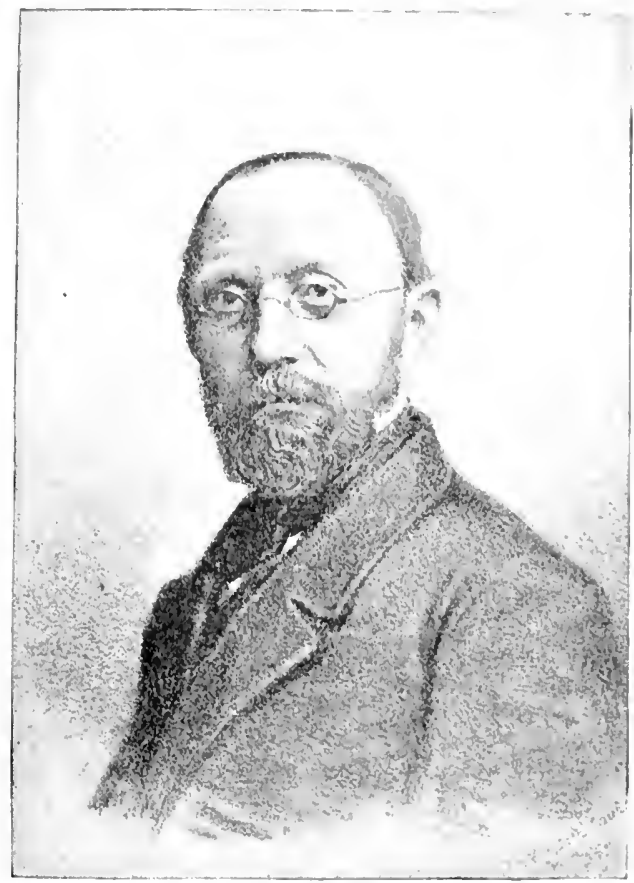

Fig, 3i.-RUnolph Vileitow.

distinguished himself by attaining the highest grate in the career of the leamed, - a professorship, which he first held in Würzburg. Inring earlier years his residener and labors were largely the result of necessities arising firom political views, for on account of these he was long denicd a residence in Berlin. A personal friend, now old, once an interne in the great Julius Spital, in Mrurzburg, at the 
time when Virchow tanght there, tells me a light was burning every night in Virchow's room until 3 A.M., and yet the professor was always out at work by $\%$. It was by such intense application that he arrived at his present position at the rery top of the professional ladder; but very few men have the physique and constitution to stand such arduous study. In 1566 he assumed the chair of Pathological Anatomy in Berlin, and introduced microscopical anatomy, to which Rokitansky had not given sufficient attention. Virchow was a former pupil of Johames Mïller, famous as a physiologist and pathologrist, and his views to-day are often tinged by the dloctrines aequired from this great teacher. He is also a great admirer of Inarey, whose picture, at least for a long time, was the only one permitted to hang in his study. His first edition of Cellulur. Pretholog!l appeared in 1858; the colossal work on Thmors in 1866, in which he carried ont the division of morbid growths originally adopted by Johammes Miiller in 183s, classifying them according to their microscopical elements. He is also scarcely more celebrated for his teachings and labors than for the number of famous pupils brought up under his influence, among whom may be mentioned Leyden, Recklinghausen, Cohmheim, IValdeyer, Kiuhne, and Rindfleisch. As a result of his labors has arisen in Germany what has been called the "Medical School of Natural Sciences," that seeks, by means of pathological anatomy and microscopy, experimental physiology and pathologry, and the other applied methods, to make of medicine an exact science; and to it belong such men as Ziemssen, Gerhardt, Nothnagel, Liebermeister, Senator, Erb, Vogel, and others. An offshoot from this is the so-called "Munich Clinical School," to which belong von Buhl. Pettenkofer, Seitz, and Oertel.

The splitting up of medicine into specialties, and the increase of its subordinate branches into schools, - so called, -resulted in great danger to the unity of medical science. 
A return to the methods which combine science and practice-the so-called clinical-practical method-is again songht by men who have established the well-known Zeitschrift für Klinische Merlicin, under the manadernent of Frerichs and Leyden,-a journal which has allearly done a great deal of good.

'The versatile Bouchut, of Paris. has recently puhlished a theory, - the so-called "Scminalism,"-for" which the claim is made that he grants nothing to hypothesis, and everything to observation; its chancteristic is that this new theory is also vitalistic,-in fact, the French have scarcely ever brought forth any other than vitalistic theories. Borden and Bartliez, during the previous century, created the first French theory, which was followed ont by Bichat, and later by Bonchut, who, as a matter of fact, owes much to Bichat. Bouchut teaches that beasts have an intelligence of instinct, and men one of abstraction; no beast orersteps the limits of animal thought, which is separated by an abyss from the productive thonght of men; there is a proper kingdom of man, in accordance with his special nature ; also, that the vital forces of men and of beasts are entirely different from each other, and that the principle of physical identity remains in the bodies of each, since the constantly renewed mass is formed in exact acrordance with the original plans; in all the changes of his elements man is identical with man ; all intermal and exterual causes of disease modify, more or less, the vital force and its impressibility in the fluids or at some point in the economy, either increasing it or diminishing it. 'This theory, pulblished in 1873, claimed "in the abstraction of its promise and completeness of its conclusions to yield to none of its preclecessors." Yet, even in France, the task of transforming medicine into a natural and exact science is fur from being a fait accompli.

The most recent theories of discase are the result of microscopical study of grerms, - the germ-theory, in fact,- 
and stand in the closest possible relation with the doctrine of spontaneons generation, fermentation, miasm, and contanion. In 18:3 Ehrenberg regarded infusoria as animals, but Dujarlin in 1841 expresecel clombts, and Perty in 1852 aflirmed that mo-t forms classified as infusoria should be assigned to the regretable kinglom, where, a little later, Naceroli relenated them. The correctness of this conchusion was proved by Colns. who also perlected a classification. 'This particular form of investigation began in the twenties of the present century and assumed its present direction in the thirties and forties. Gaspard. in 1823 , renewed the experiments of Haller, and injected into the veins of animals, not alone putrescent material, but the blood of other cratures suffering fiom the effect of such injections. Bassi. in 1835, discovered the cause of silk-worm disease, thereby giving special impulse to the theory of parasitism, and this was quickly followed by evidence of the existence of both regetable and animal exciters of disease. Schoenlein, in 1839, demonstrated the fungus of fivus; Togel discovered the Oidtium albicans in 1840); Goodsir, the Sarcina rentriculi, in 18+1; but the greatest influence upon the development of the parasitic, or germ-theory was the sequel to the discovery of the anthrax bacillus, by Daraine in 1850. In 1837 Latour and Schwann demonstrated that the cells, which were known even to leenwenhoeck, were actually vegetable forms, and Schulze had already pointed ont that fermentation of fluids could only oceur in the presence of extremely minute regetable organisms; Cherreul next showed that animal solids remained free from decomposition when protected from the access of germs; and in 1557 Pasteur demonstrated that fermentation and putrefaction were cansed, not by ehemical forms, as Liebig had taught, but simply by the agency of lower organisms, which he divided into aërobes and anaërobes; while in 1868 Chanrean queried as to whether morbific elcments resided in the formed elements of germs or in their 
fluid constituents. 'Thus the theory of ementegimm cirmm, for which Itenle contended as early als 1821 , was not formontern. In Germany likebs and Ilueter berame the prominent champions of this theory; lallier had designated his whcalled "Nicrosporon septicum," and introduced a methest of" fractional cultures. 'The views of Klebs were oppened hy Billroth, who contended for his "phlogistie Permunt" and

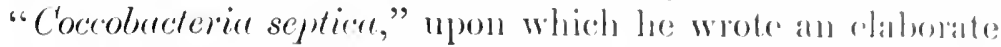
and extensively illustrated treatise; he also at that time opposed the specific character of the lowre organioms as disease agents. Mallier's microsporem was relinted by Cohn, who studied and classified the varions fouggi, and dintingruished between the pathogenic and the septiconenic.that is, those which produced disease and those which produced ordinary putrefaction. Then came the experimental evidence of Davaine and Koch, who demonstrated the development of bacteria from spores. It is hardly necessary to discuss this theory further, but I may mention the labors of Panum and of Brieger, who deeply investigated the poisons produced by bacteria, to which are given the general titles of ptomaines and toxins.

It would be unjust, however, did I not mention the name of Lister in conneetion with the inestimable benefit that has accrued to surgery from the practical application of the theory of infection to wounds, - a measure that brought about an entire revolution in surgery and surgical techmique, and an entire reversal of the statisties of operations; where thousands formerly died, thousands now live, their lives being indirectly due to the labors of this one man and his following.

I will add that it is necessary to realize the difference between life and death to appreciate the changes that have been brought about during the last score of years. Mnch that in former years was unjustifiable has become both justifiable and feasible; to-day patients, as a matter of course, live after operations which, so recently as when I 
was a student, werc considered impossible, or if performed exposed the operator to the charge of manslaughter.

I have spoken of the impulse which came from Avenbruserer's invention of percussion, which was greatly extended thromgh the translation of his work by Corvisart (1755-1821); the latter also excelled as a clinical teacher and pathological anatomist, and had much to do with the education of others of his confrères whose names are lustrons in history. Among the most celebrated was laënnec (1781-1826), who, though brought up among most trying surroundiugs, carly manifested a zeal for medicine. He became a field-surgeon in the French army soon after the Reinn of 'Terror, and pushed his classical and medical studies with restless zeal. In 1815 his first experiments were made with the stethoscope, the invention of which was due to accident: in order to hear the sounds of the heart more clearly, he one day applied a cylindrical roll of paper, and then immediately constructed the whole form of the stethoscope npon the principle now everywhere resorted to. In 1819 he published his work on Medirte Auscultution, - a treatise on prognosis in disease of the lungs and heart, based principally upon this new aid to investigation. The treatise was speedily translated into all the languages of Europe. After enjoying a large practice lä̈muec succumbed to ill health at the early age of forty-five. IIe scems to have had but slight appreciation of his own services to medicine, and to have prided himself rather on his skill in riding lorscback. Honor and fame, however, followed closely upon the publication of his wellknown work, and the mannals of physical diagnosis which now find fiequent mention in book catalognes, and come from rarious and wide sources are the legitimate ontcome of Avenbrugerer's and of Laënnec's pioneer treatises.

A rersatile French writer who devoted especial attention to medical nomenclature was Piory (1794-1879), to whom 
we are indebted for the pleximeter. 'The doulble stethoscope, a legitimate extension of läënnec's simple instrument, was invented by Cammann, of New York, and cam justly be claimed for American medicine. Other metlods of physical examination-like spirometry, chest measurement, and study of expired ail-have been introduced since 1846. The ophthalunoscope, which has been of such sterling service, and is based upon the simplest of principles, was the invention of the fimous Ilelmlıoltz, but just deceased. 'The principle of endoscopy,-the illumination and visual examination of the various carities of the human body, - the various specula, the spectroscope, the sphygmograph, the more accurate record of physical sounds, the application of electricity, and the employment of thermometry represent a few of the strides in the medical science of the present century, thereby aiding and perfecting the art of diagnosis, which, in turn, must ever necessarily form the basis for all rational treatment. Let no one complain that we are still so far from certainty in every case; the wonder is that so much has been discovered in so short a space of time.

Wonderful as have been these advances, the greatest achievements have accrued to the department of surgery, which Chamisso terms "the seeing portion of the healing art." The sixteentli century opened the way for checking of hæmorrhages; the serenteenth accomplished great simplifications and improrement in the way of dressing wounds; the eighteentl gave a refining and elerating tendency to the study of applied practice, and raised surgery to a level with other branches of science; and now the nineteenth century has, toward its close, made surgery as nearly, perhaps, as it ever can be, an exact science, to which every other branch of science has been made contributory. The chain-saw, invented in 1806 by Jeffery, alone gave an impetus to resection, which was cultivated especially in Germany ; to resection was added osteotomy by 
Heine and Mayer; this, in turn, was succeeded by the socalled subcutancous osteotomy of Langenbeck in 1854; Stromeyer introduced subeutineous tenotomy in 1831, which was a very pronounced adrance on all that had grone before; then came the introduction of ansesthesia, by which were made possible operations that had been beyond human enduance; by the introduction of the rubber bandige by Esmarch in 1873 bloodless methods were made possible. Pain and hemorrage, the two greatest enemies of the conscientious surgeon, being thus almost annihilated, there was left but an apparently theoretical limit to what the surgeon might accomplish. Orthopaedic surgery, introduced by Delpech, was unknown prior to 1816 ; it was first practiced systematically by Stromeyer and popularized in France by Guérin. Operations on nerves were studied as special methods by Schuh, Wernher, and Nussbaum. Jobert and Simon abroad, and Sims and Emmet in the United States, by their studies of fistulac peculiar to the genito-urinary tract in females, have conferred inestimable benefits upon suffering womanhood. So late as 1839 Vidal declared there did not exist in the history of surgery a single well-authenticated case of complete cure of resicovaginal tear.

It is not my intention to more than barely refer to the living sureceous of to-day, or those who have but very recently passed away from us; but it would be an injustice to overlook Bernhard ron Langenbeck and Theodor Billroth. 'The former, born in 1810 and deceased in 1887, was for a time a teacher of physiology, but subsequently became successor of Dieffenbach in the University of Berlin. The influence he exerted upon surgery in Germany and (since the decline of French precedence) upon surgery all over the world, has perhaps been greater than that of any one man since Dupuytren's time. He it was that introduced into surgical technique and surgical pathology the experimental method of which Johannes Müller was the 
great exponent; indeed, the relatively high infurtance. which pathology is given to-day in every surreical currionlum is due more to his labors than to those of any oflure one man. Genial, loamed, indefatigable, he was the bleal accomplished teacher. It would be impossible in any short résumé of his life and labors to do justice to so distinguished a man, to whom the profession owes so murh. Perhaps the highest testimonial that could be given womld

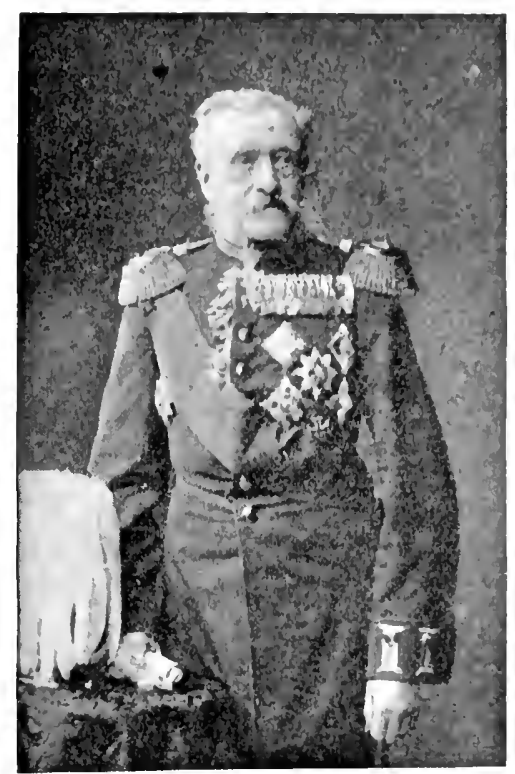

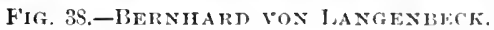

(From a photograph.)

be the enumeration of the men who were ever and ahays his enthusiastic admirers. I angenbeck was the founder of the German Congress of Surgeons, and for many years its president, and the permanent home this association has built for itself in Berlin bears his name; the surgical journal he founded has now passed its fiftieth rolume, and is today the first periodical of its class in any comntry or language. 
'Theodor Jillroth, who only within a few years joined the great silent majority, was for many years the surgical sun of Austro-Hungary, around whom revolved all the other lights of the prolession in the empire. He was as expert with the microscope as with the linife, and equally great with both. Although his great and elaborate work on Coccolucteric Septire is now obsolete, it nevertheless marked an era in surgical pathology, as does also his text-

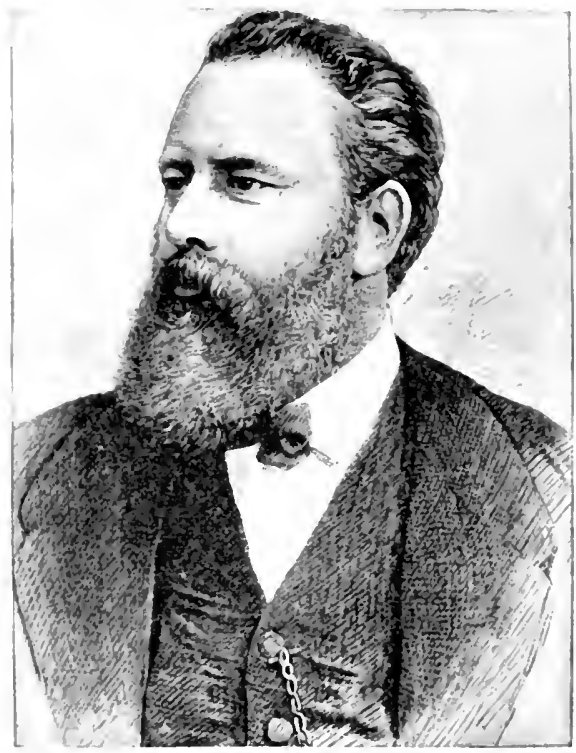

FIG. 39.-TIIEONOR BILLROTH.

(From an engraving of a recent Ihotograph.)

book on the same subject, which reached fifteen editions and has been widely translated. He it was who made the first resection of the larynx and of the stomach, and to him we are indebted for many other daring operations. It was the fume of this teacher that in recent years led young Americans to Viemna, and he set the example in every way for a constantly growing number of students whose names are, or ere long will be, famous. Billroth was born, in 


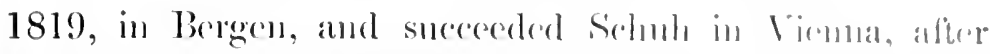
having tanght most aceeptahly at \%ourich. What he was to his teacher, Iangenhork, such alre the yommere Girman surgeons, like Crorny, (iussenbaner, Mikulic'z, and others, to him. The Russian, l'irogoff, also deserves a place here.

Here may be realled the pride with which Imoricans greet the name of McIowell, who preformed the first ovariotomy, and prepared the way for a branch of abdominal surgery the results of which have fairly astonished the worlel.

There is much to be said also for cortain measures, surh as the introduetion into surerery of plaster of l'aris, by Larrey; of starehed bandages, by Scutiu; of alisorbable material for ligatures and sutures, the latter from animal somrces. Finally, antiseptic-or, better, aseptic-mothods of operating and caring for injuries and wounds have worked a revolution in methods and results that is, perhaps, the most important known to medical history.

At the begiming of the present century the French appeared to lead in matters surgical, and were distinguished by dexterity in operating, fertility of invention, aceuracy of observation, and cleamess of elinical teaching. 'The foundation of this reputation was laid by Desault, and upon it his suceessors contimued to build. From his school descended the barber-surgeon Boyer (1757-1833), who became the first surgeon and trusted adviser of Nilpoleon, and was by him created a baron. He was the anthor of a work, in eleven volumes, which has survired many editions and translations, and therein he laid especial stress upon after-treatment. Richerand (1779-1840), like Boyer, was made a baron, and was a professor in Paris; but his character suffered from his overweening ambition and ranity; he was wont to exhibit most mpleasant personal traits; nevertheless his surgical ability entitles him to front rank among his contemporaries. The third surgeon honored with the rank of baron was larrey (1766-1842), surgeon- 
in-chief to the Grand Army, and whom Napoleon I called the most virtuous of men. In 1792 he joined the Army of the Rhine, and was the physician of the so-called "Hying ambulance" for twenty-two years. He was present in sixty great battles (including that of Waterloo) and four hundred engagements, and was three times wounded. His memoirs and monographs on subjects comnected with military surgery cause him to be often quoted even at the present day. It is recorded that he performed two hundred amputations in a single day; during the march through Russia he had at one time in Snolensk ten thousand men to care for in one hospital. A wonderful organizer, he was idolized by the soldiers, and seems to have been held in nearly the sime esteem as his great prototype, Ambroise Paré.

The most famous French surgeon of this century,equally celebrated as a diagnostician, as an operator, and as a teacher, -was Baron Dupuytren (1777-1835). As a child ho had been stolen, on account of his eminent beanty. His early life was one of poverty and want. He zealously deroted himself to anatomy and pliysiology as foundations for successful work in surgery, and ultimately secured a private practice that embraced all France, and, when visiting other countries, was received like a prince. For years he devoted three hours daily to didactic lectures. He died, learing a fortune of several millions of francs; he even offered to the exiled Charles of England a million francs as a trifling recompense for his misfortume. He was known as "The Napoleon of Surgery," - a title well earned, yet one which drew upon him the enmity of many of his contemporaries, particularly as he seemed inclined to persecute all who dared to tread in his path. His death resulted from empyema, for which he declined operation, preferring, as he said, "to die at the hands of God, rather than man."

The first truly scientific practitioner of orthopadic surgery in France was Delpech (1777-1832), of Toulouse, 
who was likewise the pioneer in suberutanenens tronotomy of the tendo Aehillis and in antoplastic operations. It his own expense he ereeted a large orthopardic: institute in Montpellier, and his death ocemred while on his way to pay a visit to this institution, both he and his roachiman being shot by an insane pationt upon whom he had operated.

Dupuytren's successor in the Hoter-I)icu was limx (1780-1854), who earned specific reputation als a dextrens and rapid operator; his labors in construetive and plastic surgery were extraordinary. 'The first to apply physical investigation to surgery was lisfranc $(1790-18+7)$. - best remembered, perhaps, in connection with amputation of the foot. Narjolin (1760-1850) was a teacher of (minence, as were also Sanson (1790-1841) and ('loquet (179)-1 $85: 3)$, though the latter is better remembered for his works on anatomy than for his exploits in surgery. Ciriale (1792-1867) is cliefly famous for revamping the operation of lithotrity, for, though a lithotrite had been invented by d'Etoilles, Civiale was the first actual operator, for which he was fiercely opposed by Iarrey, Sanson, Velpean, and others; he lived to see his rivals confounded and lithotrity accepted as a legitimate surgieal procedure. Amussat (1796-1856) reinvented torsion of arteries for the repression of hremorrhage, for, although this measure had been sugrested by the ancients, it was held to be suitable only for very small vessels; he never held a professorship, yet at his residence were hold his so-ealled "conferences" that were attended by the most eminent medical men of the time; he is specially known in connection with the operation for opening the colon in the lumbar region. Plavaz was a surgeon of Lyons, whose mame has been perpetuated by the small syringe-the original hypotermatic-which he devised. Vidal de Cassis (1803-1856) male a reputation by his work on Surgery, in five rolumes. which was extensively translated and reprinted thronghout Europe. Jobert 
de Lamballe (1799-1867) rose from abject porerty to a professorship and a seat in the Academie; he is particularly remembered for his achierements in plastic operations. Velpean (1795-1868) in 1834 became the successor of Boyer; poprular as a teacher, and an author of great fertility, he devoted attention alike to surgery and midwifery; his Operutice Surgery, in three volumes, and a treatise on Disenses of the Ifummony Glund are still classics. Gerdy (1797-1856), like Velpeau, was the son of poverty-stricken parents; in 1833 he became a professor, and wrote extensively on bandages, dressings, and on operation for the radical cure of hernia. Bonnet (1802-1858) rendered great service to surgery by his researches upon diseases of the joints. Malgaigne (1806-1865), made Professor of Operative Surgery in Paris in 1865 , devoted great attention to surgical anatomy, operative and experimental surgery, and especially to fractures and dislocations, - his work on fractures is met with on many book-shelves to-day. Nélaton (1807-187t) was surgeon to Emperor Napoleou III, and, thougl he wrote little, became peculiarly eminent as a practitioner; his ingenious probe, tipped with porcelain. by means of which he located a bullet in the foot of Garibaldi, is well known. He deroted special attention to tuberculosis of bones and joints, being, perhaps, further instigated thereto by the case of the Prince Imperial; his treatise on this subject forms most acceptable reading to-day, and he tanght the existence of osseous tuberculosis long before such was recognized in either Great Britain, Germany, or the United States.

Were I to refer to living contemporaries of many of the celebrities just mentioned, I should speak with special reverence and esteem of Péan and Vernenil, recently dead, and Ollier, who are or were the greatest surgeons in France; but with their lives and labors any one may easily acquaint himself from sources which are at the command of all.

I pass now to the Italians, who, since Scarpa's time 
have never made any very decided impression upon surerery, although there aue many most excellent practitioners of the art in Italy; the best known are l'orta (1S0)-1875), Vanzettal (born in 1809), and Rizzoli (who died in 1880); Riberi, Tizzoni, loreta, Durante, and others are, perhaps, equally entitled to mention.

Since the time of Gimbernat there have been no surgerons in Spain whose services have been sufficiontly important to rouse special attention away from their native peninsula. 'The Spaniards are well elucated, and well expipred for practice, but do not appear as great originators nor experimenters; doubtless because their merlical schools and universities long since lost prestige, owing to clerical and Inquisitorial interference; nerertheless, Spanish medical literature has kept well abreast with that of other comblries.

In Great Britain the example of John Innter, during the eighteenth century, produced results of the grratest importance; advances were made simultanconsly in physiology and pathology which the Anglo-Saxon races have been quick to utilize. While, perhaps, more conservative and less inventive than the French, the surgeons of Fugland have ever been in the front rank, and quite early they gave great attention to careful local dictetic and hygienic measures, of which Continental surgeons were, and are. too often neglectfiul. English surgeons, too, while they have been specialists, have never been quite so narrow in their respective fields as the Continental surgeons, and it has always been rare to find one who was not also a good general practitioner; the immense advantages which this added knowledge confers must be apparent. 'The most celebrated representative of British surery of this century was the son of a clergyman,-Sir Astley Cooper, born in Norfolk in 1748, but subsequently a resident of London. During youth he resolutely compressed the bleeding limb of a playmate who was the victim of an accident, so that time was gained for the arrival of a surgeon, who then tied 
the vessel; this decided his future calling, and he pursued his studies in london, Edinburgh, and on the Continent. In 1791 he settled down to private practice, which soon yielded him an income in excess of $£ 20,000(\$ 100,000)$, for his day the equiralent of thrice that amount at present. At the age of serenty-three he succumbed to a longstanding asthma. He was a somewhat voluminous witer, and his worlis on fractures, dislocations, and diseases of the

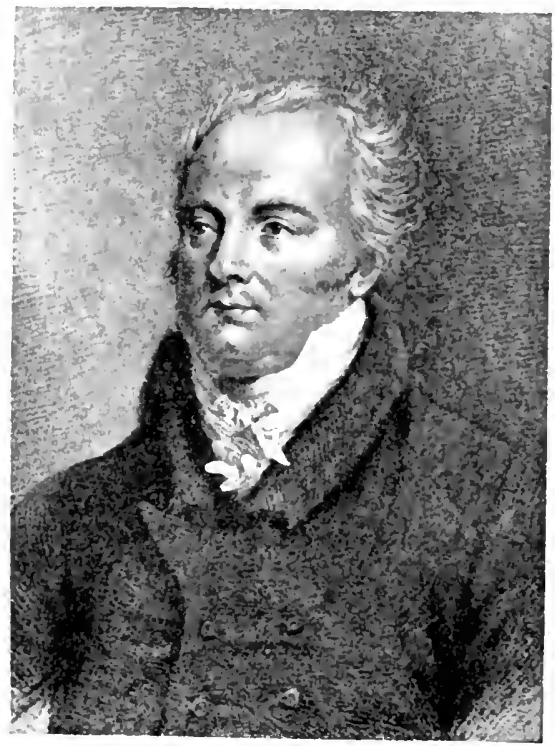

Fig, 40.-Sir ASTIEY COOPER, Bart.

(From a steel encraving of an original drawing by J. W. Rubidge.)

breast are by no means obsolete. His motto was: "First observe, and then think." Exceptionally endowed with all the graces of person, he became one of the most popular and influential men of his day; withal, he was always zealous for his profession, never unoccupied, and charitable to a high degree. Of his boldness we have evidence in the fact that in 1817 he tied the abdominal aorta, being. the first to undertake this surgical feat. 
A colleagne of Cooper's at st. 'T'lommas's ] forpital was Travers, already spoken of in connection with irritation. 'Tyrrel, a nephew of ('ooper, was a well-known surenon, particularly in diseases of the eye. (Otheres of the same natme were: Samuel Cooper (1781-1848), who wrote a whluminous treatise on practical surgery; branshy cooper (1792-1853), Sir Astley's nephew and aldopted son, who

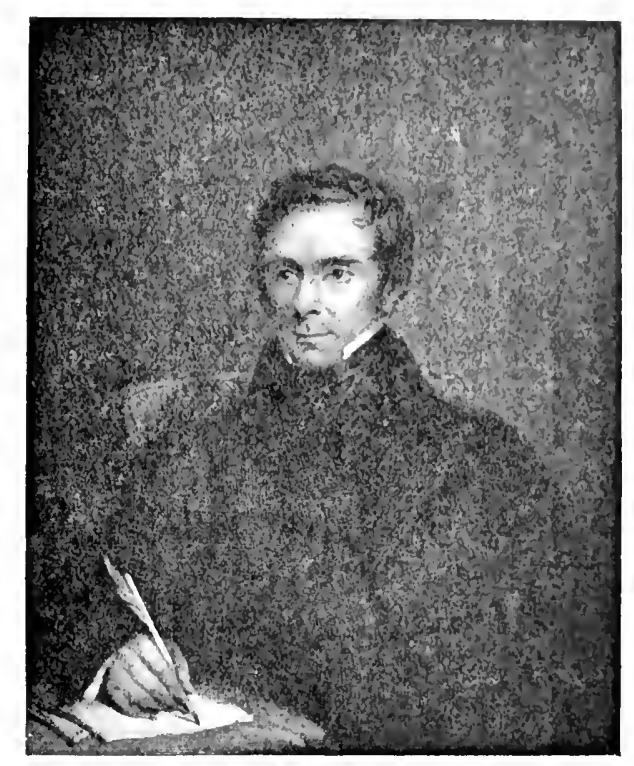

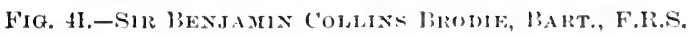

(From a steel engraving by J. Brain of a painting by 11, R.,um.)

was well known, and who achieved an eminence that is only dimmed by that of his uncle.

Sir Benjamin Brodie (1783-1862) was distinguisherl as a special investigator and a soft-tissne operator, of whom it is said that, basing his actions upon his statisties. the older he became, the less frequently he operated. Ilis bestlinown writings concern diseases of the joints. Guthrie (1785-1856), a man of noble chanacteristies, was the friend 
and companion of 1 (ellington, whom he accompanied in all his campaigns. Although well known as a lithotomist, his fame rests chictly upon studies and writings in the domain of military surgery. A colleagne of his in the Westminster Hospital, Sir William Lawrence (1 $783-1867$ ), was surgeon to the queen, highly esteemed as a dextrous operator, and an anthority on ruptures and on operative surgery. John Lizars (1783-1861) was a pupil of John Bell, and distinguished himself as a bold operator and fertile writer ; early in the century he treated chronic hydrocephahus by operation. Robert liston (179t-1847) was another remarkable surgeon and a wondertiul operator. Sir Charles Bell (177t-1842) lias already been mentioncd for his researches on the nerves, and he also wrote on operative surgery, and is somewhat famed for his opposition to renesection.

In Edinburgh James Syme (1799-1870) secured great reputation both by his dexterity as an operator-which is spoken of by his own pupils as marrelous-and by his introduction of resection into general practice. Sir James $\mathbf{Y}$. Simpson (1811-1870) aided to make the Edimburgh school famous by his researches into the domain of both surgery and obstetrics. Though the inventor of acupressure, his name will forever be associated with the introduction of chloroform. Professor Dunn says that, "after seeing the terrible agony of a poor Highland woman under amputation of the breast, Simpson left the class-room and went straight to Parliament llouse to seek work as a solicitor's clerk. But on second thought he returned to the study of medicine, asking: 'Can anything be done to make operations less painful?' The ultimate result was the discovery of chloroform, and so the suffering of one became the occasion of the deliverance of many." Upon his advocacy of chloroform in obstetrics he had to defend himself against most rehement attacks of both Scotch and English clergymen, who affected to regard such procedure as a crime that transgressed the will of the Deity; but he successfully con- 
founded these assailants with their own weapons, proving himself their more than equal in knowledge of theripture lore.

Many other British surgeons, living and dead, descrve most honorable mention, hut time and space will not permit. I camot, however, pass by withont mentioning Curling, Amnandale, ('hicne, ('heryse, Marewen, Oyston, Jonathan ILutehinson, Sir James l'aget, Christopher I leath, Thomas Langmore, Savory, Ifolden, IIolmos, Adams, Sir Joseph Lister, and Sir P'rescott Ilewitt, of the value of whose labors I have already tried to speak; Sir William Ferguson, of whom it is said that he had the eagle's eye, a lion's heart, and a lady's hand; John Bowman, best known for his work in ophthalmic surgery ; Sir IIenry 'Thompson, the eminent lithotomist and lithotritist; and Sir Spencer Wells, Keith, Lawson 'Tait, and Bantock, whose names are inseparable from the history of abdominal surgery. And what can be said of the young men who are being trained in the methods and practice of their predecessors-trained not only in the direction of mamual dexterity, but in experimental science, to which they malie the former subservient? All honor to these scions of (ireat Britain's surgical art, who have astonished the work with their consummate ability! I would that time permitted recapitulation of the work accomplished in late years by the present generation of men in london. Edinburgh, and other medical centres; but the scope of these chapters does not cover this ground. 


\section{CIAP'T'ER XI.}

HISTORY OF MEDICINE IN AMERICA.

The Colonial ['hrsiejins. Merlieal stuly under Preceptors. Inoenlation against small-pox. Military surery Juring the levolutionary War. Earliest

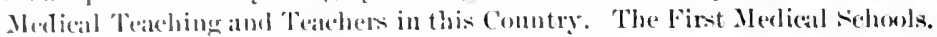
linujanin lim, 17.15-1-13. The First Medieal Jommals. Brief List of

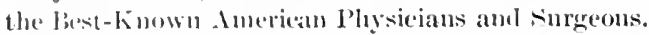

'Tue history of medicine in America commences with the early strungles of the physicians in the American colonies. One Dr. Wootton came to Virginia in 1607 as Surgeon-General of the London Company. The following year 1)r. Russell was with Cilptain Smith in his exploration of Chesapeake Bay. Neither of these men stayed long in the country, since, in 1609, Captain Smith, after being wounded, was compelled to return to England for treatment, for lack of medical aid.

When, in 1626, Peter Ninuit purchased the istand of Manhatten for the sum of twenty-four dollars, there was probably no physician there at the time. Undoubtedly the first physician, in what is now New York, was Lamontagne, -a Hugnenot, who arrived in 1637, and who seems to have been a man of great capability for his time. It would appear that men of no little eminence left the Old World for the New during the early days of the American colonies, and that the medical services which the early colonists received were on a par with those received by those whom they left behind in their old homes. During the seventeenth century a number of reputable physicians emigrated to this country, among them Dr. John Clark, of Boston, in 1638, whose son and grandson followed him in his profession and became prominent in their chosen calling. In $16+t$ came 1)r. Child, a graduate of Padua, who seems to have been a man of great learning.

A number of younger Americans also went abroad $(2 \tau 6)$ 
to study, - Ieyden, Paris, l'adna, and the Tiritish miversities being those most agerly somght. In Virginias, so early as 1619 , the Colonial Assembly discussed thre crection of a miversity or college. Tn 16337 a pmblic collenge was established in Cambridge, and in 1638 the lier. John Harvard left to it his library and half his fortume, after which it was called Harvard Collegre. William alnd Maly Collecre was chartered in Virginia in 1693. Probably the first lecet ures in anatomy given in this comntry were those of (iiles Firman, which were giren previons to l6it7 at llanvard College.

It was in this early day that arose the rustom, (ontinned until very recently, of sturlying medicine with a preceptor. 'This was necessary at that time, and mutil comparatively recently, because of the scarcity of institutions of learning and the expense comected with an elucation. The form of apprenticeship was often gone through with for a term of years varying from three to sevon, during which time the young student performed the most menial duties, had very meagre opportunity for anatomical study, and acquired his linowledge rather by contact with and absorption from his preceptor than in any other way. In this method of teaching the personal element was so pronounced that everything, in firct, depended upon the preceptor, save what natural talent and industry might accomplish. With such meagre opportunities the means for doing were equally scant. Nevertheless, emergency made many of these early Anerican practitioners self-reliant and competent to treat, according to the linowledge of that day, the various accidents then so common. In $16: 36$ the Assembly of Virginia passed a fee-bill for surgeons and apothecaries, fees, however, being often paid in tobacco, powder, lead, wampum, etc. Not a fow combined ministry of the body and the soul, and a number of eminent physicians were also preachers of more or less renown,-among them John Rogers, John Fisli, and others. 
Probably the only medical work published in America during the serenteenth century was a Brief Rule to Guide the Common People of Seu England how to Treat Themselves and Others in the Small-pocks or Meusels. 'This was printed and sold in 167\% hy John Foster, of Boston. It was printed upon one side of a single sheet in double columus, and described both of these diseases as due to the blood endearoring to recorer a new form and state.

The old English distinction between physician and surgeon was for many years quite generally preserved, but conld not persist, becanse of the different conditions under which men practiced. During this century, also, a number of midwires made excellent practitioners,-among them the wife of I)r. Fuller, one of the May Flouer pilgrims. Those colonial days, however, seem to have been free from the ravages of itinerant specialists and charlatans, who so abundantly infested Europe at the time. It is also to the everlasting credit of the American profession that it took no part in the horrible delusions and scandalous transactions comnected with the Salem witcheraft.

By the beginning of the eighteenth century the population of the United States was about three hundred thousand whites; by the end of the century it had increased to a total of about four millions. During this century a larerer proportion of educated medical men came from abroad and settled in various parts of the comntry, while the Colonial and the Revolntionary Wars offered ample opportunity for the development and study of military medicine and surgery. Commerce between the two continents increased; rommunication became more free, and the people of the Old World and the New were constantly brought into rloser relation. The most lively medical controversy of the century was, probably, that excited over the introduction of vaccination against small-pox. In previous slietches I have had to intimate that the greatest enemy of the medical profession in time past has been the clergy. In 
this particular instance, however, it was to the Rev. Cotton Mather, of Boston, that the profession is latrely indebted for the favor with which the new method was received in this country. In 1721 he called the attention of vatrous American pliysicians to the mothorl, then in vorne in Turkey, of inoculation with virus from the active discatse. Dr. Boylston, of Brookline, Mass., who sottled in Boston, corresponded with members of the British lioyal Socicty and finally determined to put the method to actual proof. In 1721 he inoculated his own son with the virns of matuml small-pox, and within the next year had inocnlited two hundred and forty-seven persons, of whom about two per cent. died of the discase; while, of nearly six thousind persons attacked by the disease in the natural way, more than fourteen per cent. died. In spite of this, the man and the method were violently attacked by the people and the profession, and found their warmest defenders among the ranks of the clergy. Benjamin Franklin, then ouly sixteen years of age, joined with the rabble in opposing the inoculation method. Boylston was threatened with hanging, and had even to hide himself for a time. He died in 1766.

After the great discovery of Edward Jenner societies were formed for the promotion of vaccination all orer the world. The earliest vaccination in the United States was performed by Dr. Waterhouse (born 1754, died 1846), who operated upon four of his own children in 1800.

It was during the eighteenth century that a number of our best-known educational institutions were founded in the different colonies,-among them, Iale College, in 1701; Princeton (College of New Jersey), in 1746; University of Pennsylvania, in 1749; Colnmbia (Jing's College), in 1754; and others only a little less known. In most of these latter were established medical departments, but the method of apprenticing students to physicians was still in general observance, no preliminary education whatever, as a rule, being demanded. In 1766, 
however, the New Jersey Medical Society ordained that no student be taken as an apprentice by any member of the society unless he had competent knowledge of Iatin and some initiation in the Greek. Abont the middle of the century I)rs. Bard and Middleton, in New York, and Dr. Cadwallader, in Philadelphia, began giving lectures in anatomy, while at Newport. Rhode Island, Dr. William llunter, between $175+$ and $1756,-$ a near relative of the

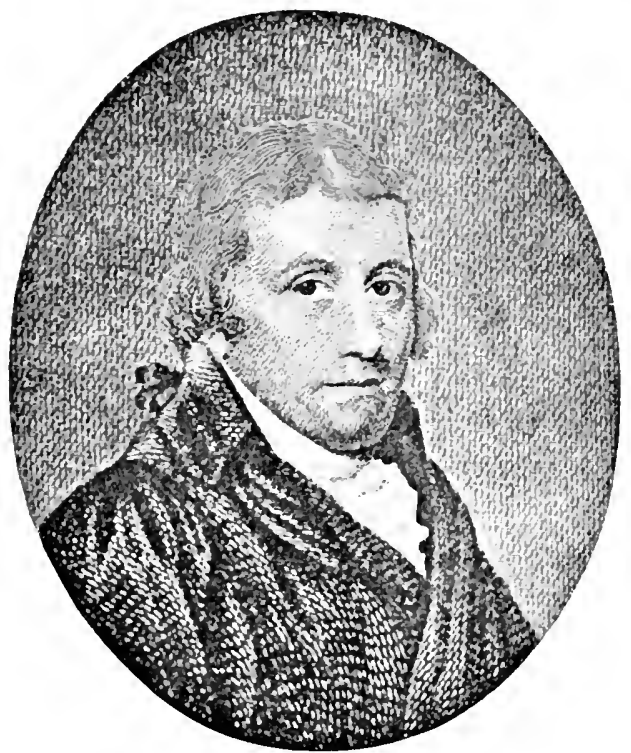

Fig. 42.-B. Waterholse, M.D.

famous Hunters of London, and a pupil of the elder Monro,-gave a course of lectures on human and comparative anatomy. Dr. William Shippen, Jr. (1736-1808), -a student of John Hunter's,-returned in 1762 to America, and gave his first course of lectures on anatomy and midwifery during the years immediately following. His lectures led to the formation of a Medical Department of the College of Philadelphia, in 1765, in which lectures were continued regularly until the winter of 1775 , when 
the War of the Revolution inforfined. In July of 1776

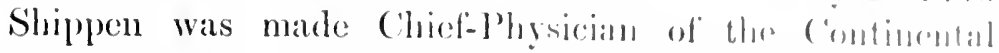
Army, and in the following year was ofereded loy the Provincial Congress Director-in-(iencral of anmy hespital. During the latter years of thro war le roturnol to hlibladelphia each winter, and delisered a comse of lertures,

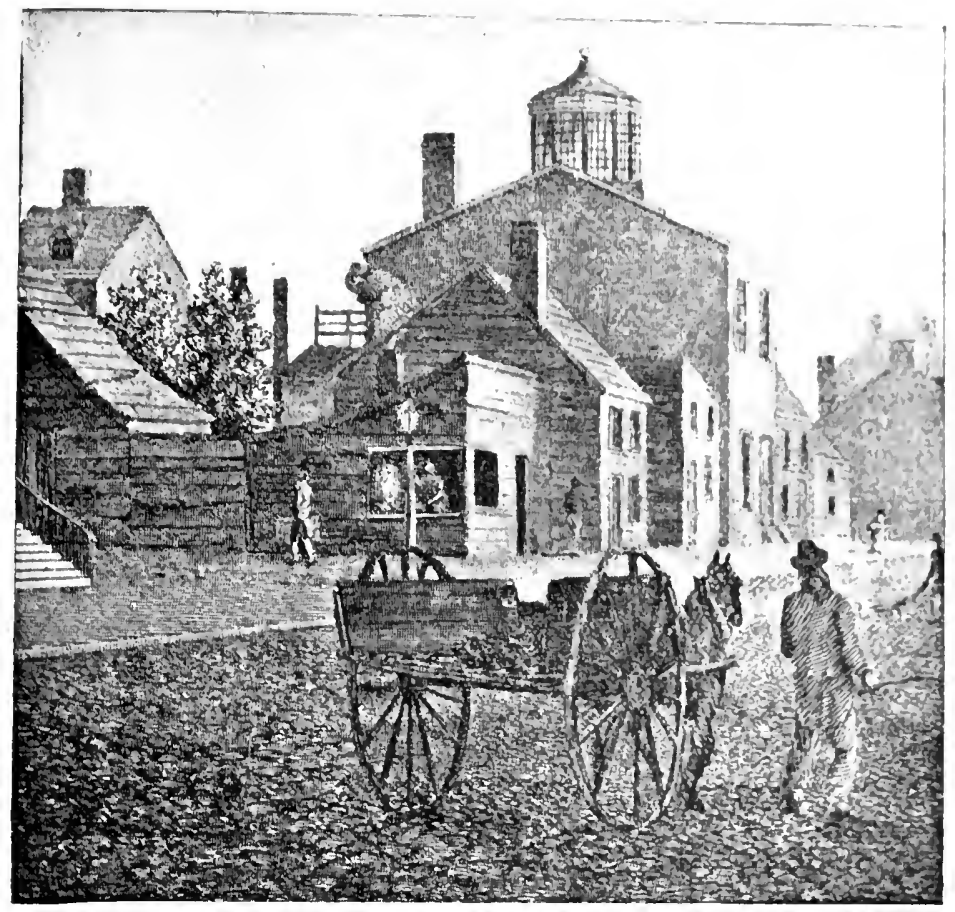

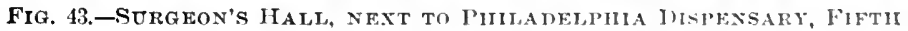
STREET IJELOW LIBRARY STRFET.

Foundation of the Medieal lepartment of the Lniversity of Pemnslrania. First medical sehool in Amerien, 176i-1 siot.

shortened by the necessities of the case. 'Thus lie was the first public teacher of midwifery in this comtry. II was ably seconded in his work by 1)r. John Morgan (1735-1789),-also a pupil of IIunter and Monro, who received a prominent army appointment in 1755, but who, two years later, was unfortunately dismissed on 
charges subsequently proved false. Shippen and Morgan were for some time the only professors in the Medical Department of the C'ollegre of Philadelphia. In 1768 Kunlu-il pupil of Limens-was made Professor of Materia Medica and Botany; and Benjamin Rush, a year later, was griven the Chair of Chemistry. The commencement of this institution occurred in 1768 , when the degree of M.13. was griven to seventeen graduates. In 1779 political reasons led to the abolition of the College of Philadelphia, the University of Pennsylvania taking its place. 'Ten years later the former institution was restored, and in 1791 the two institutions were united. The present Medical Department of the University of Pennsylrania is, therefore, the legitimate continuation of the first medical school in America.

'The Medical Department of King's College, New York, now Columbia College, was organized in 1767, by Clossey, an Irishman; Middleton, a Ścotchman; James Smith, a graduate of Leyden; Tenant, an alummus of Princeton College; and Bard, who was by far the most eminent of the group, a Plibladelphian by birth, who had studied under the best masters in England.

'The Medical Department of Harvard University was organized in 1753. Most prominent in connection with it was I)r. John Wirren, the first teacher of anatomy and surgery, and the founder of a family of eminent medical men, whose descendant, Dr. J. Collins Waren, is to-day an occupant of the chail of surgery in the same school. The Medical Department of Dartmoutl College was organized in 1798 by 1): Nathan Smith, - a man of great energy and musual versatility.

While these medical colleges were developing their strength the medical profession were not idle, and institutions and libraries sprang up in various places. The Penusylvania Hospital, for instance, founded in 1762, is to be credited with the oldest medical library in this country, 
many of its volumes having been selected especially for it by Louis, of Paris, and the limnous I dettsom, of landent. It now contains nearly fifteen thomsand volumes. 'I'he library of the New York llospital, not quite so larere, was founded in 1776 ; that of the Colleger of Physictans, in Philadelphia, in 1788. 'The profension of New Jersey organized the State Medical Soconty in 1765. In 1781 was founded the Massachusets Medical Socionty. In 1 T57 arose the College of Physicians of l'hilatelphia.

In 1789 the profession of Malyland olminimed the socalled Medical and Chirurgical Faculty of Maryland, constituting thereby the same organization as the societies of other States. Belore the close of the century, J)elaware, New Hampshire, and Sonth Carolina had also organized societies. In the larger cities extensive hospitals were also founded,- the Penusylvania Hospital, in Philadelphia, in 1751, inside of which the first clinical instruction in this country was given by 10r. Thomas Bond. The New York Hospital began in 1769, simultaneonsly with the organization of the Medical Department of King's College. 'The first insane-asylum in America was built at Williamsburgh, Va., in 1773, although the charter of the Pennsylvania Hospital, dated 1751, provided for the care of lunatics, though not at that time in a separate institution.

The most conspicuous medical character of the century in American history was undoubtedly Benjamin Rush (1745-1813). He was one of Shippen's earliest students in anatomy, studied widely abroad, was a member of the Continental Congress, and one of the signers of the 1)eclaration of Independence. After him is named Rush Medical College of Chicago. He was an extensive writer on a varicty of subjects, not only professional, but political, philosophical, etc. He recognized but two kinds of remedies, -stimulants and depressants, - and loold it to be the principal duty of the physician to decide as to which were most advisable in a given case. He called calomel the "Sim- 
son" of the materia medica, and his opponents contended that he was right, since it had nudoubtedly slain its thonsands. As an accurate observer of disease, he was correct and exact, and his descriptions are to-diy both classic and reliable.

'The study of practical anatomy has always been carried on in this comntry under great disadrantages. At first only the bodies of executed criminals were sparingly furnished.

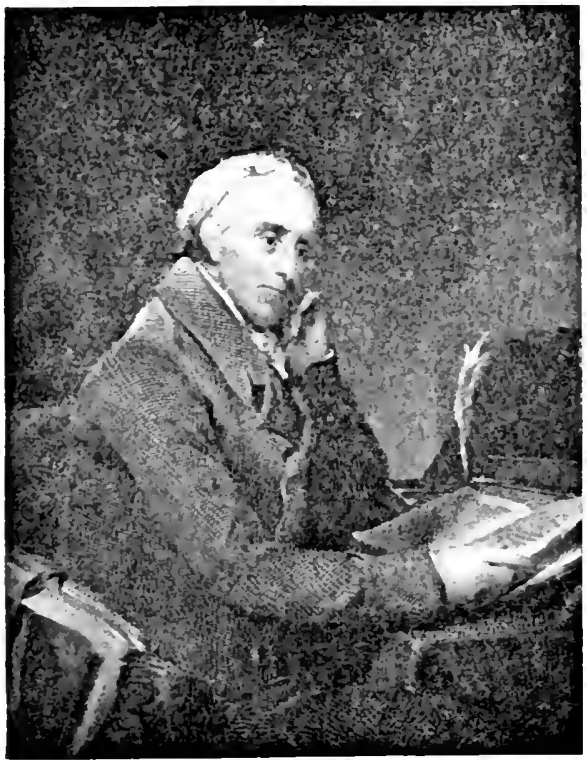

Fif. 44,-lienjanin Resir, M.D.

(From a steel engraving by R. W. Dodson of a painting by T. Sully.)

In 1788, in New York, occurred the celebrated "doctor's mob," which attested the vehemence of public objection to dissection, and which for two days defied the control of all the anthorities. Secret dissections had been practiced in Harvard Collegre so early as 1771 , but the practice was against the law even for sixty years later in Massachusctts. Physiology: as such, was not taught in any medical school in this country during the century, and ex- 
perimental physiology was practically monkown. Surgery was eagerly sturlied, especially during war times, and l)r. John Jones (1729-1791), of the King's College Sidhool, was, perhaps, the most eminent of the surgeons of his day. Others who vied with him were Willian Shippen, Jl., thes first teacher of surgery in the College of l'hilamelphiat John Warren, of Boston; Richard Jayley, of Connecticut; Baynham, of Virginia; and MeKninght, of Now York.

The position of midwifery during the earlier years of the country may be, perhaps, understood by the following extract from the New York Weelily I'ost-Bo!y, of July, 1745 :

"Last night died, in the prime of life, to the almost universal regret and sorrow of this eity, Mr. John du l'uy, M.D., man-midwife," etc.

The first practitioner of obstetries in New England was Dr. Lloyd (1723-1810), a pupil of Hunter and smelley; while Dr. Shippen, in Philadelphia, endeavored to organize a school for the instruction of midwives, in which, however, he met with insuperable difficulties.

The first attempt to regulate practice in colonial times was an act passed by the General Assembly of 1760, providing for at least a form of examination in physic and surgery, registration, etc. The first medical journal to appear in the United States appeared about 1790. It was entitled A Journal of the Practice of Herlicine and Surgery and Pharmaey in the Militury Mospitals of France, consisting merely of translations from the French jommals of military medicine. The first real American medical journal was the Medicul Repository, begm in 1797 and discontinned in 1824.

The present century, now drawing to its close, saw in its earlier half the rise of a large number of American plin sicians and surgeons who have made their names illustrious for all time by their teachings, their writings, and their invention and originality. While it is, of course, invidions 
to select names, the following certainly deserve honorable mention in this list, withont the slightest disrespect or intentional slight to many others whose names must be omitted for want of space.

John R. Cox (1773-1S64), an early student of Benjamin Rush, filled the chair of Materia Medica and Pharmacy in the University of Pennsylrania, and published the Americun Dispensutory in 1806. Caspar Wistar (1761-

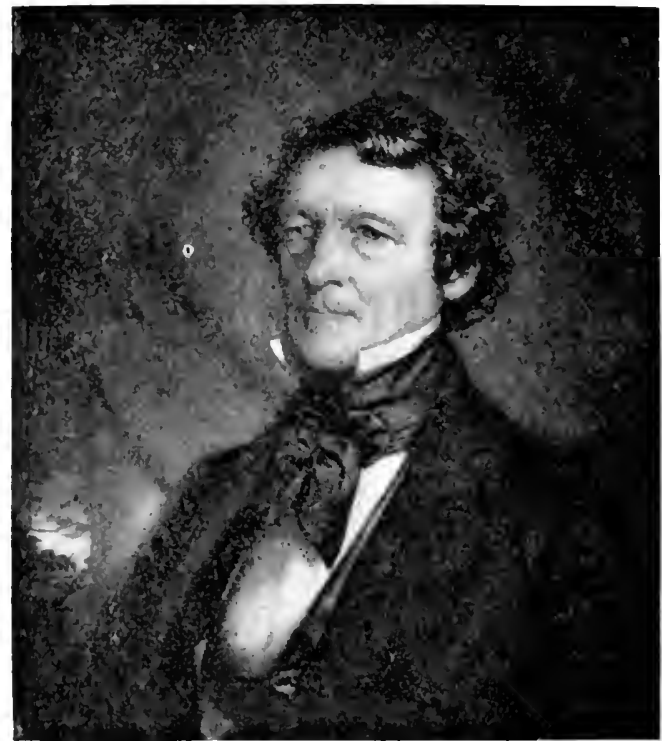

FIG. 45.-TEOHGE B. WOOD, MI.D.

(Frow an engraving by T. B. Welch, of Philatelphia, male from a daguerreotyle by McClees and Germon, of Plitadelphia.)

1818) was the author of a System of Anatomy,-held in great favor in his day as a text-book. Nathaniel Chapman (1780-1S53) wals Professor of Theory and Practice in the University of Pennsylrania until 1850. John Eberle held the similar chair of the Jefferson School from 1825-1831. The former wrote on Materia Medica and Therapentics, the latter on the Practice of Medicine, both works being exceedingly popular. John W. Francis (1789-1861) 
taught obstetrics in the College of l'hysicians and singerens from 1826-1830. Franklin Jakke (1792-1s61) wati one of the authors of the Dispensatory of the Unitred Stortes of America, publisher in ronjunction with (ionere li. IImal. who was Prolessor of Materia Medica in the Lniversity of" Penusylvania, and who wrote also extensively on his chenen subject in monographs and latge works. Robley lonnerliom (1789-1869) taught for a number of years in the Unirresity

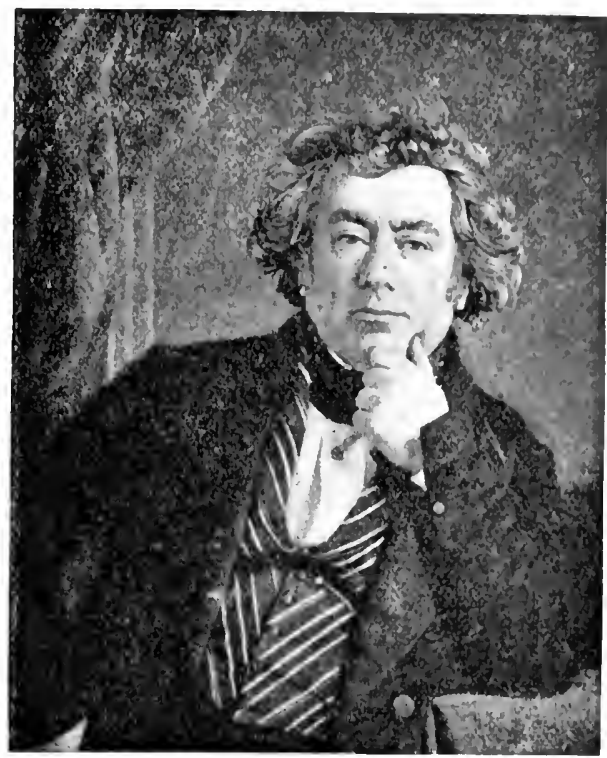

Fig. 46.-ROBLEY DUMGLISON, M.D.

(From an engraving by A. It. Ritehie of a daguerrentype by M. P. Simoue.)

of Virginia, but removed later to the Jefferson Sehool in Philadelphia. He was a man of great industry and versatility, and wrote on a variety of subjects, his best-known work being his Medical Dictionury. W. E. Horner (1793 -1853) taught anatomy and histology in the Unirersity of Pennsylvania, and will long be remembered for his researches in these branches. John $\mathrm{W}^{\top}$. Oraper (1811-1852) made himself eminent as well by his researches in photog- 
raphy and in general science, as by the publication of his treatise on Human Physiolog!, which first appeared in 1853. Better known ats physiologist was Joln C. Dalton (18251859), whose text-book is to-day studied in many colleges and who first introduced the method of vivisectional classroom demonstrations in our own school here in Buffalo.

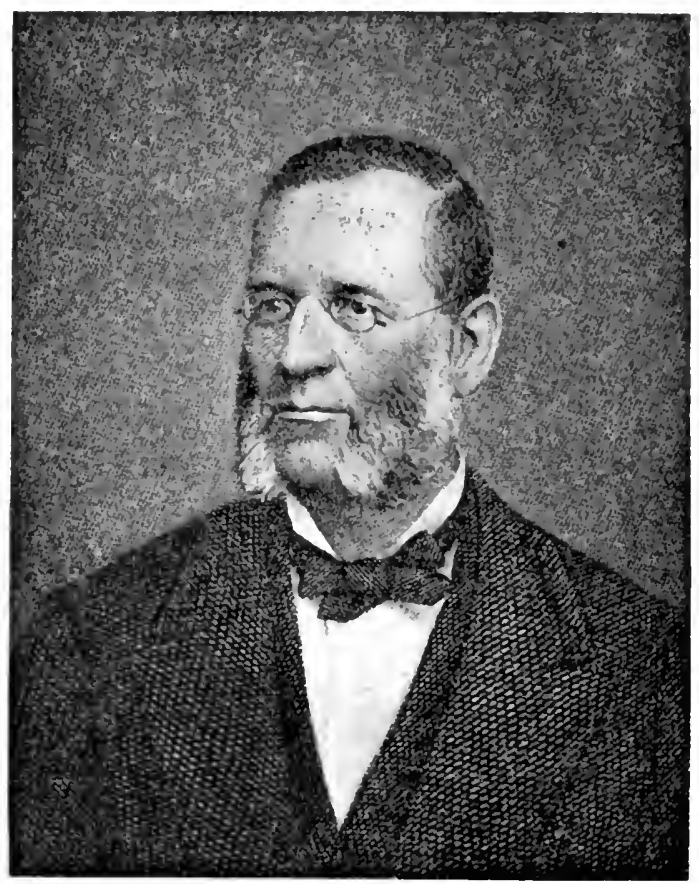

Fig. 47.-ATEstix Flist, M.D.

(From a steel engraving by 11. B. Hall.)

Alonzo Clark (180T-185i) was one of the most eminent teachers of medicine that this country has produced. Austin Flint (1812-1856) was also a famous teacher of medicine in New York, who made lis first reputation in the then small school in Buffalo. His text-book on Practice is the most popmlar American work on the subject that has ever appeared, and is still in general use. William P. Dewees. 
(1768-1841) was the author of a treatise upon J)isenses of Children, which reached a tenth edition and which rivaled the similar treatise of John Forsyth Meigs. 'T'lir? best-known teacher of dermatology and venereal diseases was Freeman J. Bumstead (1826-1879), author of the most popular work mpon the latter subject that has becu issued from the medical press. He was professor of these diseases at the College of P'hysicians in New York. Mis

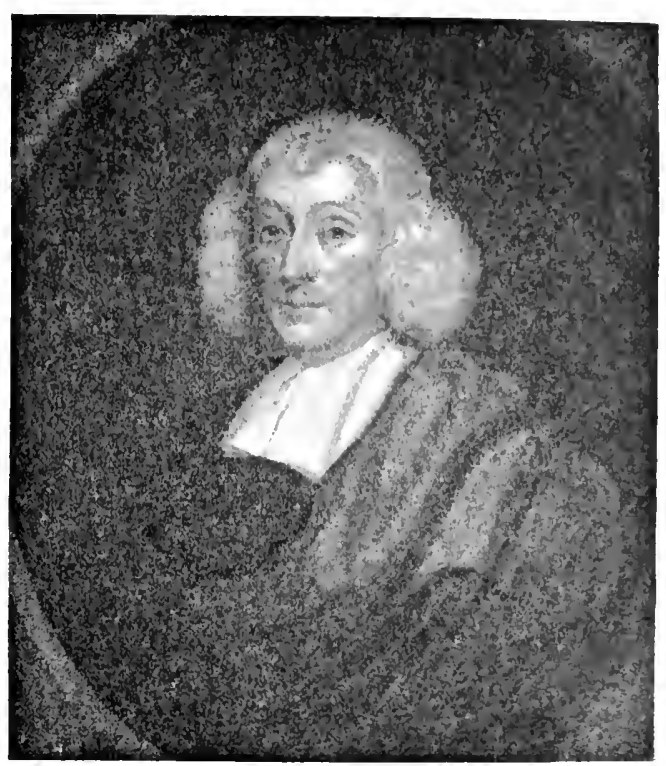

FIG. 48.-JoIIN RAY, M.D.

(From a steel engraving by II. Meyer of an original painting in the British Museum.)

text-book vied with that produced by William H. Tin Buren (1819-1883), who, in connection with Dr. Keyes (still living), wrote a treatise upon the Surgical Diserses of the Genito-Urinary Organs, including syphilis, which has been, since its appearance, exceedingly popular with the medical profession.

Among the best-known neurologists and alienists of the century since Benjamin Rush wrote his Inquiries and 
Observations upon Diseases of the Mind (1812) was Dr. Isaac liay, who, in 1838, published a work upon the medical jurisprudence of insanity. Dr. Brigham (17981849) was superintendent of the Utica Insane-asylum for some years before his death; and Dr. Kirkbride, who died in 1883, had been superintendent of the Philadelphia Asylum for over forty years. Dr. John P. Gray followed Brigham as superintendent of the Utica Asylum, where he remained for thirty-two years, and founded the Journal of Insunity.

'The first independent writer upon diseases of the ere was 1)r. Frick (1793-18\%0), of Maryland. As illustrating how little our present specialties were then separated, it is worth while to remark that Dr. Edward Delafield (1 i941575), who, in 1826, was Professor of Obstetrics and Diseases of Women and Children in the College of Physicians and Surgeons, New York, delivered at the same time a special course of lectures upon diseases of the eye. The first man in the United States to make these diseases his exclusive specialty was $\mathrm{D}_{1}$. Williams (1822-1888), of Cincimati.

It would be very wrong, in this comnection, to omit the mention of the name of Olirer Wendell Holmes, the genial "Autocrat of the Breakfast Table," but recently dead at a ripe old age, who used to say that he was "seventy years young," who was for a long time Professor of Anatomy at Harvard Medical College, but who was much more widely known and endeared to the English-speaking public by his bcautiful poems and most attractive prose writings, - who, as author of the Chambered Nutitus, for instance, will be remembered so long as the English language has a literature and is read. He rendered a great service to the medical profession by first calling attention to the contagiousness of puerperal fever. Of his prose writings, his medical essays-entitled Currents and Counter-currents-make perhaps the most delightful reading. 
Not a few Americans deserve special montion ats smegeons and surgical teachers of emincher during the pant hundred years. Without being invidinss, them must. nevertheless, be mentioned John (Bollins Wanten (17is1856), first Professor of Anatomy and surene in the Ha1vard School, under whose anspices rether wals first alministered for the purpose of surgical anasthesia, and who was the founder, in 18:28, of the Bostom stediral and singricul

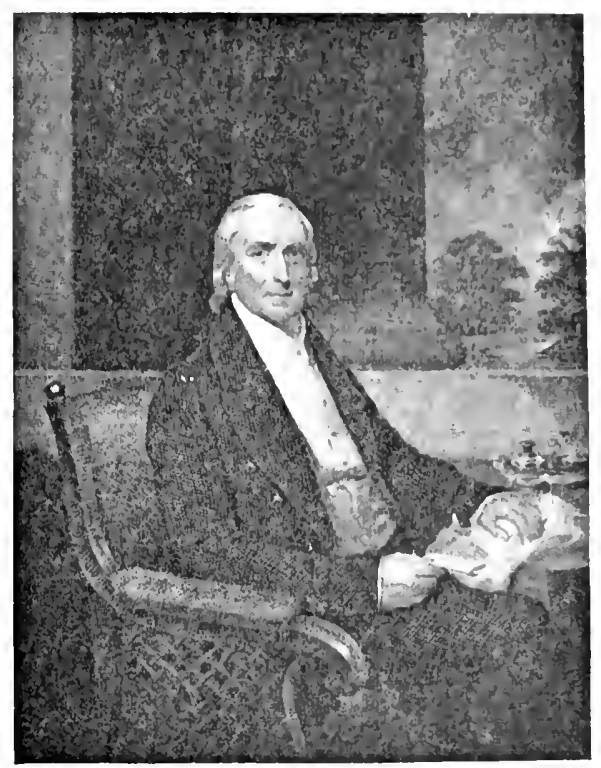

Fig. 49.-PIHIIP SYNe PIIYSICK, M.D.

(From a steel engraving by R. W. Dulson of a paintugg ly 11. Inman.)

Journal. He wrote an extensive treatise upon tumors, and, it is stated, first successfully tapped the pericardium. Philip S. Physick (1768-1837), a pupil of Hunter, has been spoken of as the "father of American surgery," which he taught in the University of Pennsylrania. He was a tremendous worker, but wrote very little. He cmployed animal ligatures made of buckskin. John Srng lorsey (1783-1818) was a nephew of Physick; taught anatomy 
in the Unirersity of Pemsylrania; wrote a treatise on surgery, which was the second surgical text-book published in this conntry, and was the first in the United States to tie the external iliac artery. He died at the age of thirty-five, at a time when he was giving promise of exceeding eminence. Nathan Smith taught in Dartmouth, Yale, and Bowdoin Colleges, and was considered the best man of his day in New England.

Ephraim McDowell (1752-1830) lived in Danville, Ký

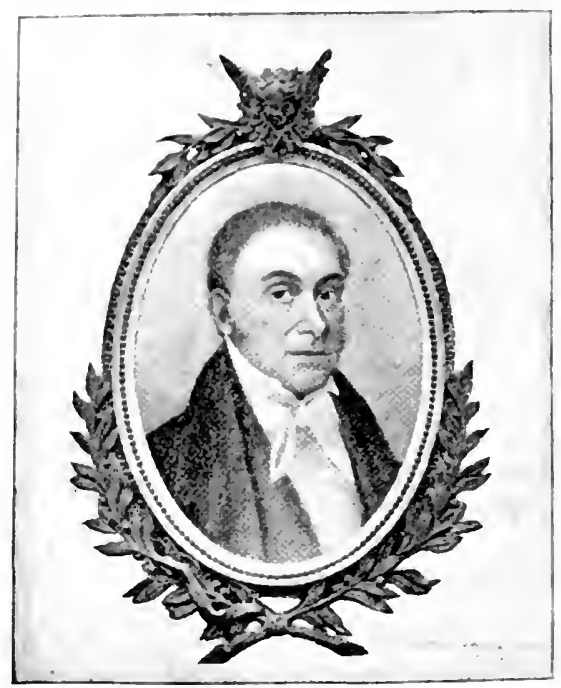

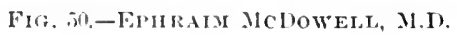

To him is justly due the great honor of having performed the first rational and deliberate oucriotomy, which he did in 1809 , his patient living for thirty-two years. The operation was performed withont an anæsthetic, and considering the circumstances under which it was carried out has shed a lustre upon his name and brain which nothing can ever dim. By this performance he became practically the father of modern abdominal surgery, and to him Americans 
and Europeans alike are delighted to render all the lonor that is his due.

Perluaps the most eminent surgeon of the comutry was Valentine Mott (1785-1865), a pupil of Cooper and Pull, who taught in the College of P'hysicians and Surgeons, New York, until 1840, and in the University Medical School until 1860. He was a man of exceedingr boldness and brilliancy, whose operations were performed at a time when anæesthesia was unknown, or was in its infancy, and who probably did more work in the surgery of the vasenlal system than any other surgeon who has erer lived. He was the first to tie the arteria immominata, - in 1818. As Gross wrote of him, he had a record of one hundred and thirty-eight ligations of various large arteries, - a record probably never equaled. He was also the first to do a successful extirpation of the clavicle for tumor,-an operation which at that time was considered very formidable. 'Though not a great writer himself, he is best known among students as the translator and editor of Velpean's large work upon operative surgery.

Dr. George MeClellan (1796-1847) was the founder of the Jefferson Medical School, and its first Professor of Surgery. He was followed later by 1)r. 'Thomas 1. Mutter, who left his surgical museum to the College of Physicians of Philadelphia and endowed a lectureship there. J. K. Rodger, of New York; John Rhea Barton, of Philadelphia; William Gibson, of Philadelplia ; Gurdon Buck, of New York; Willard Parker, of New York; Frank H. Hamilton, of New York, who made his reputation while teaching in our Buffalo school, anthor of a most popular and valuable treatise upon fiactures and dislocations; and Henry B. Sands, of New York, were men of greatest prominence during the middle and latter portion of the present century, each of whom has contributed in his way either to the science or to the literature of surgery. 'The most prominent figure in American surgery of the past 
forty years was Sammel D. Gross, of Philadelphia, professor in the Jefferson school, to which he moved from Kentucly, where he laid the foundation for his attainments and reputation. He was an carly writer upon surgical pathology and anatomy, but is best known for his elaborate

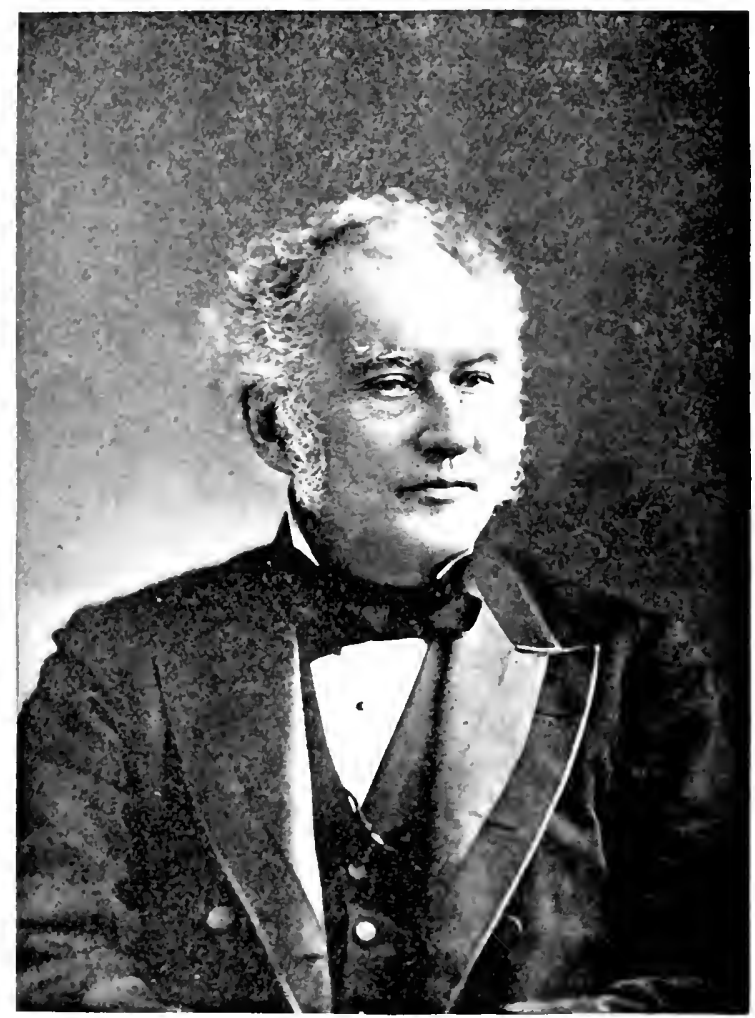

Fig. 51.-S. D. Gross, M.D., LL.D.

(From a photograph.)

System of Surgery, in two large volumes, which has surrived several editions and is still most highly esteemed. Among others who ought to be mentioned are Nathan R. Smith, of Baltimore, the inventor of the anterior splint; Paul F. Ere, of Nashrille; John T. Hodgen, of St. Louis; 
Daniel Brainard, of Chicago, and his sncerssole, Moses Gumn; Alden Mareh, of Albany'; Ienry J. Rigelow, of Boston, who performed the first excision of the hip in this country, in 1852, and who invented the method of crushing and removing stone from the bladker at it single operation, known as litholapaxy; and D. Hates Agnew, of Philadelphia, who finished, hefore his death, a large and elaborate treatise on surgery, in three thick volumes.

Of obstetricians and gynecologists America has laad no lack, and, in fact, the United States may almost be said to be the first home of gynecology. Dr. Jiard was the first Professor of Midwifery in King's ('ollege, now C'olumbia, New York, and the anthor of the first work upon the subject published in this country. In Philadelphia, I)r. Thomas C. James (1756-1835) was the first distinct teacher of obstetrics, his chair falling later to J)ewees, already mentioned, who wrote extensively on midwifery and the diseases of children and of women. The same chair in the University of Pemsylvania was filled later by Hugh L. Hodge (1796-1873), a man of great originality and independence, who published a most elaborate and beautiful work upon his branch, which will always remain a classic. Charles I). Meigs, professor in the Jefferson School, Philadelphia, was the first to direct attention to thrombosis as a cause of sudden death in childbirth. He wrote both on gynecology and milwifery. Bedford, of Baltimore, was another popular teacher and writer, with whom deserves to be mentioned William H. Byford, of Chicago, who wrote on both obstetrics and gynæcology.

Gynæcology owes much to the efforts of American schools and practitioners. The first successful attempt of McDowell's, already alluded to, was imitated by Nathan Smith in 1821; and during the next forty rear's thirty-six ovariotomies had been performed by eighteen different 
surgcons, with a record of twenty-one recoveries. Probably the most prominent passed figure in American gynæcology is J. Marion Sims (1813-1883), born in the South, where he invented his well-known speculum in 1852, whose introduction marked an epoch in the treatment of the pelvic diseases of women. It was also in South Carolina, among poor negro patients, that he perfected his method of plastic operations in the vagina for the relief of

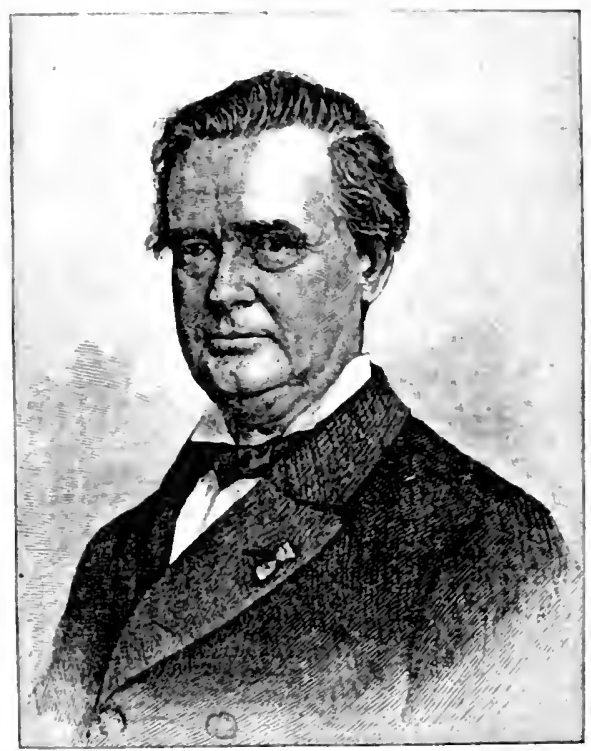

FIG, 52.-J MARION SIMS, M.D.

vesical fistulæ, which he later demonstrated in Paris to the astonishment of incredulous Parisian surgeons, who had almost uniformly failed in their attempts, and which he later successfully and brilliantly performed in all the capitals of Europe, where, as in this country, he enjoyed the greatest reputation. He was the founder of the great Woman's Hospital in New York, in 1855, an institution from which has proceeded more good gynæcological teaching than from any similar institution in the world Other 
ovariotomists and gymecologists of ereat merit were Johnt L. Atlee, and his brother Washington $\Lambda$ there of l'omms]-

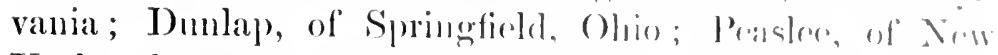
York, who wrote the first American lreatise on oratran

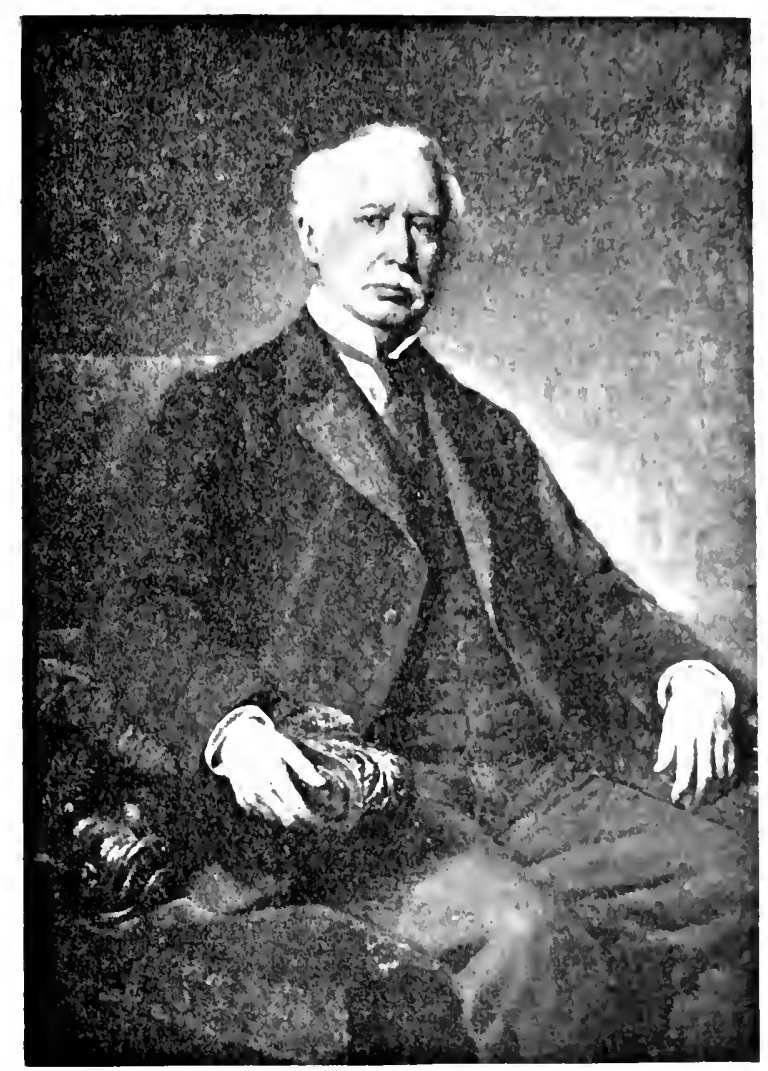

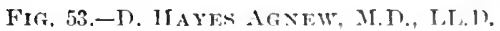

(From an oil potinting of lwy in the college of Physteitns, phitadelphia.)

tumors; Kimball, of lowell, Massachusetts: and 1). II. Agnew, of Philadelphia, who is, perhaps, yet better known as a general surgeon because of lis magmum opus.-his Treatise on Surgery, in three large volumes, alrealdy mentioned. 
After this brief résumé of the names and achievements of the best-known Ameriean physicians and surgeons no longer living, it remains only to say a few words with resard to the gencral character of their work and attainments. It rertainly was the case, during the earlier and midelle portions of this century, that men had much to gin, beside addition to their rernacular, by study in foreign countrics. Edinburgh and London were, at first, the centres to which men flocked; during the middle of the century they gathered in laris, attracted by such men as Broussais, Velpeau, and others; after which the tide of travel turned toward Germany, where the government does more for the education of medical men and the furnishing of distinct opportunities than is done in any other part of the world. But, thanks to the influence of the foreign schools and the receptivity and natural quickness of the American mind, we have reached a point in this comntry when it is no longrer necessary for American students to visit the foreign centres for this purpose, adrantageous as these may be in many respects. The only feature in which we are yet lacking is the matter of government aid and the government control of medical institutions, by which better opportunities may be afforded for pathological study. Aside from this, and the centralization of cases which government control permits, it may be said that the Americans are in all respects as good prictitioners as-and in most respects better than-their foreign colleagues. They evince more of humanity, more of real interest and care in their patients, and more consideration for their comfort and welfare; while, in all that pertains to fertility of invention, to originality of performance, and accuracy of work, they, as a rule, excel. Divested of glamour, American surgery, both general and special, is ahead of most of that which one can see abroad, and the therapeutics of the American profession certainly surpass those of any other nationality. No one need feel, then, that it is necessary to go abroad for 
any purpose, unless it may be that polish and wide range? of general information that necessatrily come fiom tratel and observation among other nations and peoples. In practical melicine, then, as in practical living, Amrricat leads the world. 


\section{CHAPTER XII.}

\section{TIIE HISTORY OF AN ESTHESIA.}

Anresthesia and Analgesia. Drugs l'ossessing Narcotic P'roperties in use since l'rehistoric Times. Mandragrora; Thenp; Hasheesh. Sulphuric Ether and the Ien Concerned in its Introkluction as an Anesthetic-Long, Jackson, Wells, and IIorton. Morton's First Public Demonstration of the Value of Ether. Morton Entitled to the Credit of its Introkluction. Chloroform and sir James Simpson. Cocaine and Karl Foller.

IT is not, perhaps, generally understood that we owe the term ancesthesic and the adjective ancesthetic to the genius of Dr. Oliver Wendell Holmes, who suggested their use to Dr. Morton. The term ancesthesia is applied to the artificial loss or deprivation of all sensation, which may be either local or general. It should be distinguished from analgesia, which means simply freedom from pain, conscionsness being retained. In this respect local anresthesia is really local analgesia, although the terms are confused in this regard.

Anæsthesia, in its present sense, is truly a modern discovery, which is to be credited to the United States. In its less restricted sense, however, it is a condition brought about by numerous drugs,-intoxicants, narcotics, etc.,some of which have been more or less in use for centuries. Anæsthesia is also a condition which may be produced in the hypnotic sleep,-a fact well recognized by the ancients, although the attention of scientific men was scarcely drawn to the fact until the days of the notorious Mesmer. The substances which ma produce loss of consciousness may be taken intentionally or unintentionally, and may be taken into the stomach, beneath the skin, or, when gaseous, through the lungs, in which absorption of the same into the blood is very speedy. It is not at all mlikely that the curious effects ascribed to some of the ancient oracles were $(30())$ 
due to the inhalation of gases arising from natural springs or produced from other somrees.

'The most common somee of nareotic druges has always been the vegetable kingdom; and the peomlian effects of the juices or other ingredients of the poppy, henbane, deadly-nightshade, Indian hemp), mandracora, ete., have been sung in poetry, rehearsed in prose, and known from almost prehistoric time. Ulysses and his companions were stupefied by nepenthe; a draught of vinegar and myrth, or gall, was offered to Christ upon the cross, as it often was to malefictors; and IJerodotus spealis of a peculiar habit of the Scythians, who produced some stupefying vapor,-probably from the seed of the hemp. From J3iblical times, at least, the most common narcotic seems to have been alcohol in some of its numerous combinations. Furthermore, the effect of hemlock has been celebrated since the days of Socrates, who was permitted to drink it in order to soothe himself during his last homr.

Mandragora seems to have had a great reputation in times past, - so much so that it is probable that more than one substance was included under this term. Apulcius, who lived about a century later than Pliny, wrote: "If any one is to have a member mutilated, burned, or sawed, let him drink half an ounce of mandragora with wine, and let him sleep till the member is cut away, withont any pain or sensation." Among the Chinese and the Indians similar drugs seem to have been in frequent use, especially the bhang, ordinarily known as hasheesh. In many parts of the East something of this kind was administered to condemned criminals, as well as those compelled to undergo rude operations. It is said, also, that mild intoxication was produced among the fanatics of the East for the purpose of firing them to the point of heroic deeds, as it is also said that among the Druids the practice prevailed of partially stupefying the novitiates betore initiating them into the most sacred and secret rites of their cult. 
Guy de Chanliac was almost the only surgical writer of previous centuries who has referred to agents for the relief of pain, althongh during and before his time it was customary to give something to those about to undergo torture, by which to deaden their sensibility ; and, though in the fables of all lands and all times something has always figured to which was ascribed the power of making people oblirious to pain or to the peculiarities of their situation, it is very difficult to learn just what, if any, particular composition was referred to or deserved such mention. 'There is allusion to something of the kind in Romeo and Juliet; agrain, in Cymbeline; and in one of Middleton's tragedies, published in 156\%, entitled Women Beucre Homen, occurs this passage:-

\section{"I'll imitate the pities of old surgeons \\ To this lost limb, who, ere they show their art, Cast one asleep, then cut the diseased part."}

Larey, in his military campaigns, noticed the effect of cold in diminishing sensitiveness, and suggested that cold might be made a useful local anæsthetic. Many surgeons used to operate upon patients under the influence of alcoholic narcotization. It was in 1776 that Mesmer arrived in Paris and became the exponent of so-called "animal magnetism,"-later termed "mesmerism," now known as hypnotism,-under the influence of which he reduced to the state of unconscionsness of pain (i.e., analgesia, as well as the more complete condition, anæsthesia) a number of patients, who were operated upon without feeling the slightest suffering.

But, in spite of the carnest attempts of humane surgeons in various parts of the world, no agent had been discovered which was proven safe and generally effectual, up to the time, for instance, of Velpeau, who in 1839 wrote: "To escape pain in surgical operations is a chimera which we are not permitted to look for in our time."

The substance known as sulphuric ether has been 
known since the thirteenth century, when, als it appears, Raymond Lulli made certain-perhaps ambignousreferences to it. In 1540 it was known its the swect wil of vitriol. It was not called an ether mutil 1 1330, "lu(n Godfrey spoke of it as such. It was freclucently refermed to during the last century by varions writers, and the first reference to its inlatation serms to have been published in 1795 by Pearson. In a work by lieddoes, on fiurtitims Airs, published at Bristol, in 179)(i, is a statement that "Ether in pectoral catarrh gives almost immediate relief, both to the oppression and pain in the chest." Beddoes also states that after inhaling two spoonfints he soon fell asleep. Later it was in somewhat gencrall use internally for mitigating the pains of colic. Iyy 1812 it wats often inhaled for experiment or diversion, its peculiar exhilarating effects being generally known. So it is, perhaps, not strange that so soon ats it was definitely recommeneded for purposes of surgical aniesthesia, a number of clammints for the honor of its discovery shonld quickly arise.

It was the same with nitrons-oxide gas, which had been known for a number of years, and which was repeatedly used for the purpose of aniesthesia before the introduction of ether for the same purpose.

Chloroform was discovered in the year 1831 by Guthrie, of Sackett's Harbor, New York, and about the same time by Sonbeiran, in France, and liebig, in Germany. But, although before the profession for sixteen years, it was not recommended for the same purpose as sulphuric ether until 1847 , and then by Doctor-later, Sir-James Simpson.

For all practical purposes we may limit further consideration of the history of anesthesia to these thrce substances, and mainly to the consideration of the introduction and adoption of ether, which displaced nitrous oxide, preceded chloroform, and has held its own to the present day as the anwsthetic in most general use, although 
in many respects inferior to chloroform. But the glamour of history pertains mostly to ether, because of the peculiar diffieulties and incidents attending its production.

For the honor of its discovery there are four claimants: -Crawford W. Longr, of' Danielsville, Ga.; Charles 'T. Jackison, of l'ymouth, Mass.,-both physicians; Horace Wells, of Hartford, Yt., and William T. G. Morton, of Charlexton, Mass.,-both dentists. It is only fair to each of these four men to consider briefly the merits of the claims made for each, while at the same time attributing the final success of the new agent to the happy accidents which permitted Morton to make a public demonstration of its power in the Massachusetts General Hospital, before such eminent nen as Warren, Bigelow, and others, by whose influence and reputation the agent was at once received upon its merits. This was on the sixteenth of October, $18+6,-\mathbf{a}$ year which deserves to be memorable in the history of medicine.

Crawford Long graduated, in 1839, from the medical department of the University of Pennsylrania, and settled in Jefferson, Georgia, where it seems to have been a common thing to have what was known as "ether frolics," during which the exhilarating effects of the inhalation of the drug were matters of common sport and amusement at rarious small gatherings. Long himself frequently inhaled the drug and often felt its benumbing effects. It is stated that it finally occurred to him to give it a trial in a surgical operation. and that, in March of 1842 , he removed a small tumor from the neck of a patient thus anæsthetized and without any pain. Owing to the sparseness of the population and the lack of dissemination of medical knowledge in those days, no public report was made of these operations, which produced nothing more than local town-talk. A young student of Long's, named WVilhite, kept a negro boy under the influence of ether for some time, to Long's surprise. Long lived one humdred and 
thirty miles from any railroad, and the first published account of his operations appeared in 1849, which was sugrgested by an account of Morton's work, which he hat read in the editorials of the Hediral Errominer for I lecernber, 1846. Iong died in 1878, the mufortunate controversy in which the four claimants alrealy mentioned participated being not yet eoncluded. Nevertheless, there is every reason to think that he is entitled to the crolit of having first anesthetized a patient with sulphuric ether for the purpose of producing insensibility to pain.

Horace Wells began the study of dentistry in 1834, in Boston, and later opened an office in IIartford, Connecticut. He seems to have been a young man of great ingenuity, continually making new instruments and derising new experiments. 'To him is to be eredited the first operation ever performed without pain by the use of nitrousoxide gas. In 1844 a Dr. Colton delivered a lecture in Hartford upon the subject of this gas. A young man who inhaled it, and became excited, ran against some furniture, badly bruising himself, but made no complaint of pain. Wells, noticing this, said to a by-stander that he belicred that one, by inhaling a sufficient quantity, could have a tooth extracted or a leg amputated without pain. The following day he inhaled the gas himself and had a tooth extracted by a Dr. Riggs. Wells remained unconscious for a little while, and, on recovering conscionsmess, cried out: "A new era in tooth-pulling! It did not hurt me as much as the prick of a pin! It is the greatest discovery ever made!"

He at once began the manufacture and use of the gas, which became quite general in that locality. His attention was also called to the action of the rapor of ether, which Dr. Marcy, a physician of Hartford, suggested to him to try as a substitute for gas; but Wells, finding it more difficult to administer, discontinned it and confined himself to the use of nitrous oxide. A month later Dr. Marcy 
gave ether to a sailor for a small operation, the man feeling no pain. 'These experiences of Wells and Marcy occurred two years after Long's work with ether, each being in total ignorance of the experiments of the other.

In 1845 Wells visited Boston for the purpose of introducing nitrous oxide as an anesthetic, and called upon his fellow-dentist and old partner, Morton, among others. He was discomaged, with his lack of success, returned to Hartford, and continued the frequent use of gas for a comple of ycars longer, but met with no encouragement in introdncing it for general surgical purposes, on account of prejudice and fear upon the part of physicians and surgeons. Wells died in January, 18t8, a few days before the Medical Society of Paris passed a resolution that to him is due all the honor of having first discovered and successfully applied the use of vapors or gases whereby surgical operations conld be performed without pain. There stands to-day in Hartford the monument erected by the city and the State, with the following inscription:-

"Horace Wells, who discovered anesthesia, November, 1814."

William 'T. G. Morton was born in 1819, and, after failing in business in Boston, in 1840 went to Baltimore and studied dentistry. In $18+1$ he entered the office of Horace Wells, above alluded to, as assistant, and in 1842 became his partner, after having introduced a new kind of solder for fixation of artificial teeth to gold plates. In 1843 this partnership was dissolved, Wells moving to Hartford, while Morton, in 1844, entered the office of 1)r. C. P. Jackison as a medical student, matriculating in the IIarvard School, but never graduating. After Wells's visit to Boston, during which he tried to introduce " laughing gas," Morton and he had numerous interviews, especially with regard to this gas. Morton was not well versed in chemistry, and sought the advice of his medical preceptor, Jackson, with regard to its manufacture. Asking 
why Morton wished to malie it and beiner told the reacon. Jackson suggested the use of sulphuric ether, just as Marry had suggested its use to IT clls, sagying that it wath taly to procure, safe in employmont, and equally puroluretise of results. He also stated that the stuclents at (ambridge? College often inhaled ether for amusement. ()n the rvening of the same day, September 30, 18t6, Morton atdmin-

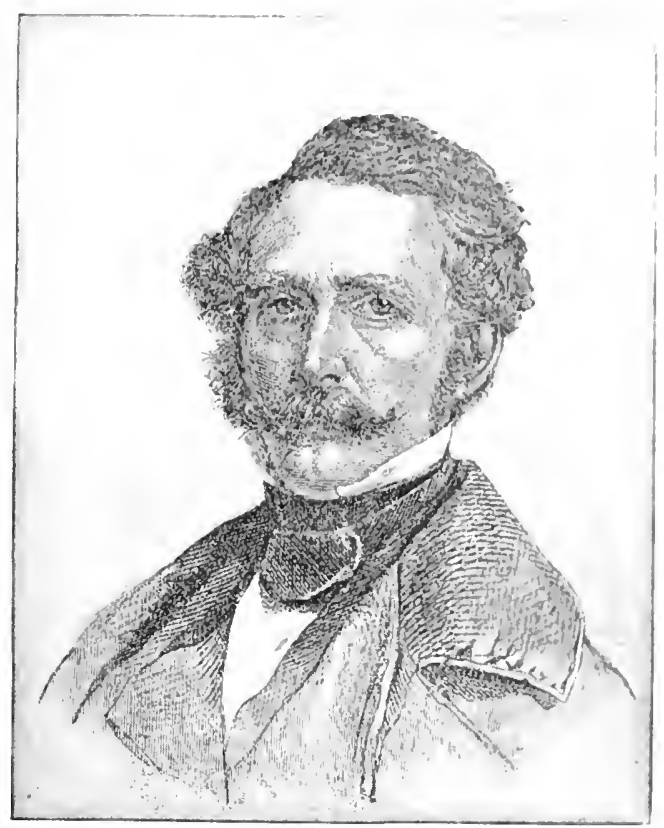

HIG. 54,-IVIlliaM T. G. MORTON, M.D,

istered ether for the extraction of a tooth, the paticnt stating that he had felt no pain. On the following daly he visited the office of a well-kinown patent lawyer for the purpose of securing letters patent upon his supposed discorery. 'Ihis lawyer, learning of Jackson's conncetion with the subject, took time to consider the matter, consulted witl Jackson, and came to the conclusion that the patent must be a joint affair, neither one having exclusive right to claim it. But 
Jackson, fearing the censure of the Massachusetts Medical Society should his name be connected with the patent, and Morton-ils a dentist-haring no such fine scruples, it was agreed that the patent should be made out in the names of botll, but that Jackson was to at once assign his interest to Yorton; in return for which he was to receive a ten per cent. commission. Meantime Morton called upon Warren, one of the surgeons in the Massachusetts General Hospital, who promised his co-operation and sent him an inritation to test his invention in the hospital on October 16, 1846. The elinic-room was filled when Morton placed the paticnt under the influence of his letheon, as he had named it; after which Warren removed a tumor from the neck of a young man, and, as it appeared, withont pain. Upon the following day another operation was performed upon a young woman, with the same happy result, while on November th an amputation was made, entirely painlessly. At this time Morton endearored to disgnise the odor of the substance he was nsing by aromatic oils. It was not until the staff of the Massachusetts General Hospital declined to use an agent whose composition was kept secret that Morton revealed publicly the fact that this was nothing but sulphuric ether disgnised by aromatics. From a report of the Commissioner of Patents, published a little later, the following paragraph is taken, the report being in the nature of a commentiry upon the discovery:-

"It has been known for many years that the vapor of sulphuric ether, when freely inhaled, would intoxicate to the same extent as alcohol when taken into the stomach. The fact has stood, further, upon the pages of science for many years that the inhalation of sulphuric ether was productive of temporary narcotic stimulant effects."

After the issnance of letters patent Morton began selling office-rights, such being the custom then, as now, among the dental profession, who are much more commer- 


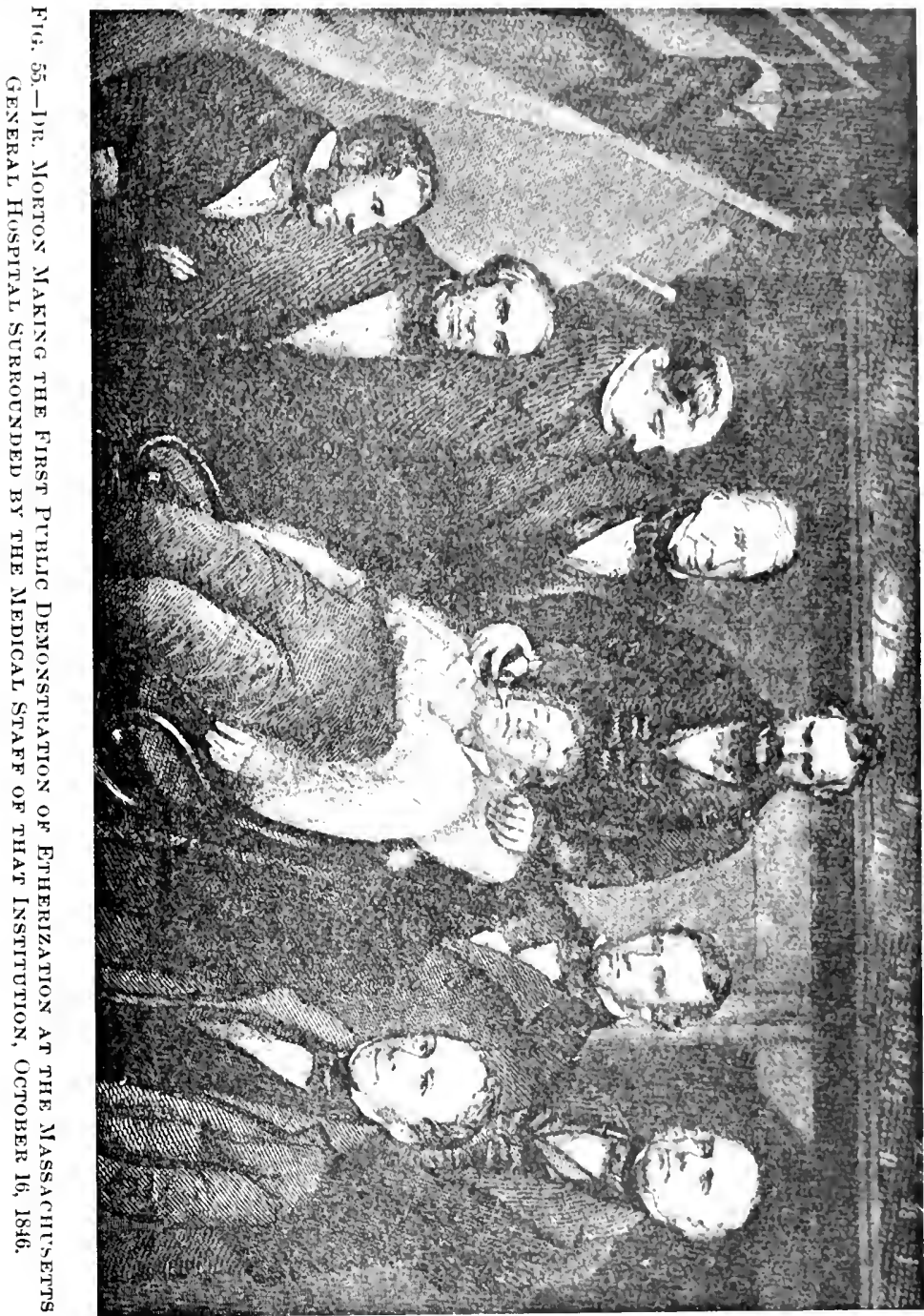


cial in their proclivities than their brethren of the medical profession. The result was an almost endless litigation, with the development of the greatest personal animosity and rivalry between Jackson and Morton, as well as the friends and descendants of the other claimants. Morton wrecked his fortune and ruined his health in his efforts to get substantial recognition and remuneration from the United States Gorerument; and the history of his repeated attempts to interest Congress and the various officials of the government, from the president down, is instructive, but fir from pleasing, reading. In these attempts he practically failed, and died from an illness contracted through exposure, after maddening disappointment, although he had been the recipient of mumerous honors and some small pecmiary recognition from societies and individnals. Morton died in 1868. In reviewing the history of his life and labors there is much to justify the inscription upon the monument erected to his memory at Mount Aubum Cemetery, Boston :-

"Inventor and revealer of ancsthetic inhalation, before whom in all time surgery was agony, and by whom pain in surgery was averted and annulled ; since whom science has controlled pain."

Charles T. Jackson graduated at Harvard Medical Collegre in 1829, after having led an already eventful career as geologist and mineralogist. He spent several years abroad, meeting many of the most distinguished men upon the Continent and displaying, in many ways, a great deal of scientific talent and mechanical ingenuity. In 1835 he opened, in Boston, the first laboratory for teaching analytical ehemistry in the United States. A year later he was made State Geologist of Maine, and spent. three years in this eapacity. He also did a great deal of work upon the State geological surveys of Rhode Island, New Iampshire, and New York, while he was the first to call attention to the mineral resources of the southern shore of Lake Superior, where, in 1845, he opened up. 
copper and iron mines. In 1846 and 1847 he lname decply interested in the subject and discosery of anderthesia, and after the suceessfin introduction of ether in Morton, in the Massichnsetts General Mospital, set up the claim that it was he who had streñested it (o) Morton. h a pamphlet, published a little latro, he states: "In the year $18: 37$ I discovered that ether-vapor was superion to alcohol as a remedy for the stramgliner and toxic reflects of chlorine-gas after inhalations for that purpose in my labloratory." He then relates how he arministored the vinum to himself for the relief of the irritation produced hy inhaling chlorine, and describes his sensations upon going to sleep and awakening. 'This claim in its entirety was a great sumprise to both Morton and Wells, and led to at most unseemly diseussion, which derenerated into a downright professional fight. After the death of IT alls, Jackison and Morton both claimed that nitrons-oxicle gras was not an anasthetic, and that insensibility to pain could not he produced by it, in consequence of which the use of the gas was quite discontinued. It became, then, simply a question of priority as to the administration of ether for relief of pain during surgical operations. Wrells being dead, this bronght Long into the conflict. Jackson risited Europe again, and presented lis claim before numerous societies in such a way as to be recognized abroad as the discoverer of ancesthesia. The relative merits of the whole controversy appear to have been pretty well summod up in a memorial sent to the Seliate and House of Representatives by several hundred members of the Massidehusetts Medical Society, which contains the following paragraph :"The undersigned hereby testify to your honorable bodies that, in their opinion, William 'T. G. Morton first proved to the world that ether would noduce insensibility to the pain of surgical operations, and that it could be used with safety. In their opinion, his fellow-men owe a debt to him for this linowledge." 
In the Public Garden in Boston there has been erected a monument to the memory of the discoverer of ether, the donor being, at the time, nnable to mention the individual to whom it should be dedicated. Upon one face is this inscription :-

"To commenomate the discovery that the inhaling of ether causes insensibility to grin, lirst prosen to th. world at the Mastachusetts General Hospital, in linston, Getoher, 1046."

Upon another face are these words:-

"In gratitule for the relicf of human suffering ly the inhaling of ether a citizen of Poston has ereeted this monument, A.D. 186\%. The nift of Thomas Lee."

Morton's untimely death, largely due to disappointment and, as he thought, to persecution, has been already mentioned. In 1873 Jaclison's mind became deranged, and he died in an asrlum in 1880.

Sir James laget has summed up the relative claims of our four contestants in an article entitled "Escape from Pain," published in the Nineteenth Century for December, 1879. He says: "While Long waited and Welis turned back and Jackson was thinking, and those to whom they had talked were neither acting nor thinking, Morton, the practical man, went to work and worked resolutely. $\mathrm{He}$ gave ether successfully in serere surgical operations, he loudly proclaimed his deeds, and he compelled mankind to hear him." As Dr. Morton's son, Dr. Wr. J. Morton, of New York, says, when witing of his father's claim: " Men used steam to propel boats before Fulton, electricity to convey messages before Morse, vaccine-virus to avert small-pox before Jenner, and ether to annul pain before Morton."

So much for ether. I have already stated that chloroform was discovered by Guthrie in 1831. But, though discovered in this comntry, it was first introduced as an anæsthetic agent in Scotland, by Simpson, who, in 1847, at the age of thirty-six, began to direct his attention to the 
discovery of some means of alleviating patin during rhildbirth, having a very large obstetric pratetice. Simposon was not satisfied with sulphuric ether, because of its stromer and disagrecable odor, and incuired of his friend Maldie, Master of Apothecaries' Hall, of liverpool, if he kuew of nothing likely to be a satisficetory substitute. Millide, acquainted with the rhemical composition of chloric ether, suggested that chloroform be prepared from it and med. Simpson experimented with this in 1847, and astablishod its anasthetic properties, which he male known through a paper read on November 10th of the same yeall. It wats arranged that upon the 13th of the month a public test should be made at the Royal Infirmary; hut Simpsom, who was to administer the chloroform, was mavoidalbly detained. Accordingly the operation was performed as of yore, without an ancesthetic, and dming its performance the patient died upon the table. IIad this deatlı taken place during the employment of chloroform, it would lave been the death-blow of that substance as an anastlictic. The first public trial took place two days later, the test proving a great success. Simpson goes down in history, then, not as the discoverer of anasthesia, but as the one who introduced chloroform for anasthetic purposes. He died in 1870, and upon his bust in Vestminster Abbey is this inscription :-

"To whose genins and benerolence the rorld owes the blessings derived from the use of chloroform for the relief of suffering."

It is a bit of most interesting medical history that after Simpson's announcement of his discovery he was riolently and vehemently opposed by the Scottish clergy, who reviled him for endeavoring to relieve the pains of childbirth, basing their opposition upon the primeval curse: "In sorrow shalt thou bring forth children." And the bearttiful ease with which Simpson refuted this childish sophistry must ever be memorable; for with one short argument he silenced his opponents and turned upon them 
the ridicule of the entire profession. For he reminded them that the first operation recorded in history was performed under ancesthesia, since, when God created Eve from one of Adam's ribs, he "caused a deep sleep to fall upon Aclitn."

Cocaine is now such a miversally recognized local anxsthetic that there is the best of reason for referring to it here-the more so because it aftords another opportunity to do honor to a discorerer who has rendered a most important service not only to om profession, but to the world in general.

The principal active constituent of coca-leaves was discovered about 1860 by Niemamn, and called by lim cocaine. It is an allaloid which combines with various acids in the formation of salts. It has the quality of benumbing raw and mucous surfaces, for which purpose it was applied first in 1862 by Schroff and in 1868 by Noreno. In 1880 Van Aurap hinted that this property might some day be utilized. Karl Koller logically conchuded from what was known about it that this ansesthetic property could be taken advantage of for work about the eye, and made a series of experiments upon the lower animals, by which lie established its efficiency and made a brilliant discovery. He reported his experiments to the Congress of German Oculists, at Heidelberg, in 1884. News of this was transmitted with great rapidity, and within a few weeks the substance was used all over the world. Its use spread rapidly to other branches of surgery, and cocaine local anæsthesia became quickly an accomplished fact. Nore time was required to point out its disagrecable possibilities, its toxic properties, and the like, but it now lias an assured and most important place among aniesthetic agents, and has been of the greatest use to probably ten per cent. of the civilized world. To Koller is entirely due the credit of establishing its remarkable properties. 
Syuthetic chemistry lats alvaned so far that artificial substitutes for cocaine are now matre, thourdh by somewhat complicated processes. 'Thus encuine and holowime are now found for sale in the drug-marlicts of both this ronntry and Europe. These substances possess propertien quitr. similar to those of cocaine, while being, as a mole, less foxir, even if a little slower in their aletivilies. In resperet to the former this is much to be desired. (enaine always deserves to rank with the "drues that enslave," and much harm and misery have come from its indiserect or indiseriminate popular use. It should always be repuresented and dispersed as a dangerons, even poisonoms. drug, though, like opium, possessed of wonderlul properties. 


\section{CHAP'TER XIII}

\section{THE HISTORY OF ANTISEPSIS.}

Sepsis, Asepsis, and Antisepsis. The Germ-theory of Inisease. Gay-Lussac's Rescarches. Schwann. Tymall. I'astenr. Javaine. Lord Lister and his Epoch-naking lievolution in Surerical Methots. Molifientions of his bitrlier Technique withont Change in Enderlying J'rinciples, which Still Remain Inshaken. Chamges Elfected in Consequence. Comparison of Old and Monlern statisties.

Monfrn surgery, and, in no small degree, modern treatment of all disease, have been so completely modified from previous methods by the introduction of the so-called antiseptic system that it seems to be only right to devote some time in such a work as this to a résumé of the history of the doctrines and experiments which have led to the perfection, as it would seem, of modern methods.

The arljective "septic" comes from the Greek word "sepsis," which is often transferred to the English, and which means "putrefaction," or that which is putrid, or undergoing decomposition. From this word are formed two others,-namely, "aseptic" and "antiseptic,"-the one implying the exclusion of all causes of putrefaction and complete freedom from it, the other referring to methods employed to antidote the effect or counteract the influence of the agrencies which produce sepsis or destroy them while still within the living body. By general usage the term "antiseptic" has been construed as the more comprehensive; lience, the modem method is usually spoken of as "antiscptic surgery." and hence the title above: "The History of Antisepsis."

The principle underlying the resort to antiseptic methods is summed up in the expression, now so generally received, -the "germ-theory" of disease. It refers, in general, to the so-called zymotic, or infectious, diseases, whose manifestations are protean, which are all communicable by one (316) 


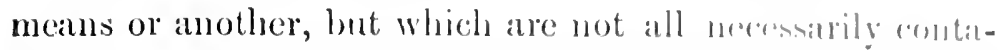

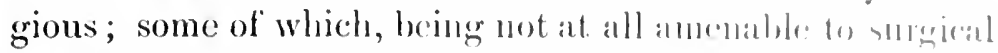
treatment, are regarded as "modioal" discatses, while uthols, which occur mostly in commection with sulgrical rasto, of

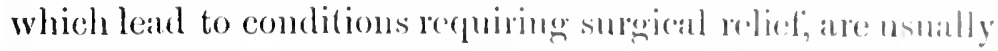
spoken of as "sulgrical" dinrasses. As ravellent and only" too common examples of these zymotice discases mily he: mentioned tetanus, erysipelas, purporal ferer, t! phond fever, and those varied conditions which are genelurally" grouped muder the term "blood poisoning." 'I'hose which most concern the surecon, and those in which most remitriable relief has been ohtained are clyipelas and the ramous forms of blood poisoning. 'These, in their valucol maniliestations, have, until recently, been literally the temen of surgeons, and in military hospitals, for instance. labre hecm the cause of more deaths than have ever lesulterl from wounds directly upon the battle-ficld. In civil hospitals, as well as in general and private practice, the molality from these diseases was, mutil fwenty-five years ago, simply frightful ; while frequently, and over wide areas of truitory, endemies and epidemics of puelperal freremould wesult in the death of almost every lying-in woman. In comsegucnee of this terrible death-rate surocons were afraid to oproute, and certain classes of operations, especially those on the abdomen and joints, were never performad, cxecpt under most exacting ciremmstances. Jut few of the present goneration can actually realize the completencss of the chaneres brought about by the adoption of the germ-theory, and the plactical effect of its use as a working basis for combating disease.

While no intelligent student at mesent denies that the infectious diseases-of which the above namod are but a very few-are the result of the introduction into the body, from without, of minnte living ormanisms, for the most part vegetable, - thus constituting them in reality, as they are often called, parasitic diseases,_but few are so familiar 
with the history of modem discovery as to appreciate the basis upon which it has been demonstrated. 'T'he proof of the germ origin of disease is the legitimate onteome of the discovery of the actual causes of fermentation and putrefaction.

Aside from the crude and often wild notions which have appeared here and there in literature of previous centuries, about the first accurate investigations bearing upon this subject were with reference to the ause of alcoholic fermentation. About the begimning of this century Appert published a monograph upon the Art of Pieserving Animal and Tegetable Sulstances, which consisted in placing them in closely corked or stoppered bottles, and exposing these to the temperature of boiling water. Gay-Iussac, the celebrated chemist, noticed that so soon as these vessels were opened, particularly if much exposed to air, their contents began to at once ferment or putrefy. This led to investigations into the production of alcohol, and the antiseptic effect of pure oxygen-gas; from which he conchuded that oxygen is necessary at the commencement of the process, but not throughout its continuance. Some thirty years later, Schwam, by the use of the microscope, then reasonably dereloped, discovered in fermenting. substances numerous very minute globular bodies, which had the power of reproduction, and which were present in juices or fluids undergoing alcoholic fermentation, but not in others, and which he concluded to be the exciting cause. Schwamn also discovered that if, in ressels sealed by Appert's method, he allowed air which had been previously heated to come in contact with the fluids, no change resulted; from which it was evident that it was something other than the gaseous elements of the air which provolied fermentation. Scluwam's investigations were corroborated, in $18+3$, by Helmlıoltz.

Schwamn's results were contested by Liebig, one of the most eminent chemists of his time, who proposed a very 
different theory, ascribing putrefaction to the absronce of oxygen and to the upsetting of moleconlal ardaneroments. He believed that non-nitrogenons substanees did not spontaneously undergo putrefaction when pure, but they must be bronglit into contact with some substance alomaly modergoing change, which latter was called a fermenl. and which converted the oxygen of the are into (athonie arid. According to him, the ferment was some material molergoing decomposition.

The next researches on this subject wore those of Schroeder and Dusele, in 185t, who studind the quention whether filtration of air would prevent the formentation of boiled fluids to which such filtered air might have access. The material used for filtration was cotton-wond: and they showed that air filtered through it was deprived of the agencies which produce formentation. 'I'hon came lasteur, who repeated the experiments of his prodecessors and elaborated and ronfirmed them. Ile also found that it was not necessiry to filter the air of its contained particles, but that if it were simply left undisturbed until these had settled by gravity, it might then be brought in contact with putrescible substances without cansing any putrefaction.

In 1870, in a lecture upon haze and dust, 'Tyndiall demonstrated beantifully and in public the presence of comntless particles in the air, as well as that these were the agencies operating to produce modesirable changes in organic substances. Both Pastrur and 'Iyndall, as woll as others, showed, as did also lister, that heat as well as filtration was sufficient to render these particles imocuons. As the result of these and numerous other experiments, by various observers, which there is no time here to recount, it was gradually and irrefitably established that the gases of the air, per se, are powerless to cause fermentation or putrefaction in boiled fluids or tissues, or in material germ-free when exposed. It was sufficient, in order to so 
purify the air, to either previously heat it or filter it through cotton-wool or through fluids inimical to germlife. while the boiling of organic material or its subjection to the boiling lieat of water was suffieient to destroy all germ-activity in it at the time, or, as we say now, to sterilize it.

In this way, and even before any minute and systematic study of bacteria,-i.e., before the inauguration of bacteriology as a separate department of scientific study,-it was practically established that the agencies which produce putrefactive changes or fermentation were minute particles which were ever present in almost cvery substance, and that by heat or something corresponding to filtration it was possible to remove them or destroy their activity.

So much had been established withont reference to the etiology of disease. In order now to study the germ-theory of discase as applied to man we must go back a little, neglecting the vagaries or the pure conjectures of the ancients, to the era of pure philosophic speculation,-perhaps to the days f Needham and Buffon,-to the middle of the previous century, when seientists and naturalists began to discuss the so-called spontaneous gencration of ife; for it is well known that fluids, like milk and others, abound with life after a few days of exposure; and it was supposed that the living organisms it contained had a spontaneous origin. This question of the spontancous beginning of minute living forms was agitated for a century, or practically until Tyndall and Pastem gave it its death-blow by their aceurate and convincing demonstrations. There was no lack of experimentation, but there was lack of exact knowledge and of aceurate deduction from facts observed. 'The bacteria-which at that time rere usually spoken of as "monads" and "vibriones," because of their spontaneous motion-were found under rarying circumstances, which, not being scientifically inquired into, led thinking men into a most perplexing con- 
dition of mind. The two most aldent recent androntes of spontancons generation were bastian, of kngland, whos wrote an elaborate trealtise upon the subject, and Jeflites Wyman, of Cambridge, Mass., who gatve it the hendit of' all his influenee. But, under the influenee of blows dralt from the side of the physical baboratory by 'lymall, and from that of the biologists by l'asterre, the theory was weakened and effectually killed, so that to-dity no one thinks of such a thing. On the contring, life secms to be inevitably the gift of a preceding orghuism; and whilo the real origin of life is as unkuown to-day as ever, there is not a single firct in the possession of scientists now justifying the view that life can have a spontancous origin. Moreover, the researches of l'asteur and others into alcologlic fermentation and the rôle played by the mimute yeast-plant, and the early researches of Pastemr, Inarine, and Foch into the role of micro-organisms in producing disease in animals, and the scientific and elaborate study of bacteria and vegetable molds, inamgunated by Colm and continued by many others, have as their legitinate outcome the creation of bacteriology as a science, and the establishment of the fact that the real condition in the so-called infertious diseases is one of fermentative or putrefactive alterations in the fluids and tissues of the living body, corresponding in minutiæ to the changes produced in saccharine fluids by the yeast-plant, or in decomposing aninal or vegetable matter by the many known bacteria which are capable of producing such changes. To put it in another way, disease is simply an expression of the fact that these mimute organisms, which are visible only under high powers of the microscope and which reproduce their kind with astonishing rapidity, gaining access to the surface or interior of the body, begin there to thrive and multiply, taking up from the living animal material for their own nourishment, thus robbing their host of that upon which his tissues must live, while at the same time, as the result of their activity, they 
produce various substances which, so far as they are concerned, are excretory in nature, and many of which are extremely poisonous to the animal organism which harbors them. Such a disease as puerperal fever, for instance, is simply an expression of the fact that within the living human body there is going on active putrefactive change, by which the internal cells are being destroyed, this destruction being progressive and often far-reaching; and that, as the result of their presence in the still living body, the noxious or toxic excretory materials of which they gret rid are absorbed, in consequence of which such rarying symptoms as nausea, fever, purging, vomiting, delirium, and many other symptoms are produced, the objective evidence of their local activity being the actual destruction of tissues, as is seen in cases of abscess, phlegmonous erysipelas, etc. The condition known everywhere as gangrene, when moist and offensive, is nothing but the putrefaction of tissues en masse. which are not yet detached or separated from the living body of which they but recently formed a liring part.

Experiments with organic material ontside the body have amply demonstrated that such putrefactive processes can be checked by certain precantions,-such as filtration of air, heat, etc. It remained for the genius of Iister to show how similar processes of putrefaction and exclusion of grems could be made serviceable for the prevention of disease in the human race. To Lister, then, is due the credit of having originated the antiseptic system and brought about a condition long yearned for by surgcons throughout the world, but never previously attained. What a revolution he wrought by his masterly researches can be appreciated only when one compares the impunity with which surgeons now perform operations which, in the preantiseptic era were regarded as absolutely unjustifiable,a conclusion amply warranted by the statistics of that era. Great as is the credit due to Lister, it is equally desirable to state that his work was, for the most part, based upon 
the researches of 'Tyudall, P'astoll, and Korh. Whirl, hanl established the germo nature of the terrible infertions dineases and the germiciclal effect of tiltration, ol luat, and of certain other substances and mothosts which furmitted of the development of his own system.

'lhe antiseptic methorl, as it hats since lown known, wats

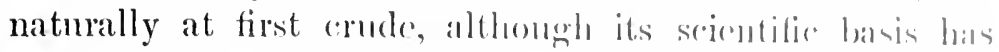
never been shaken; and that it has boen since, in burere

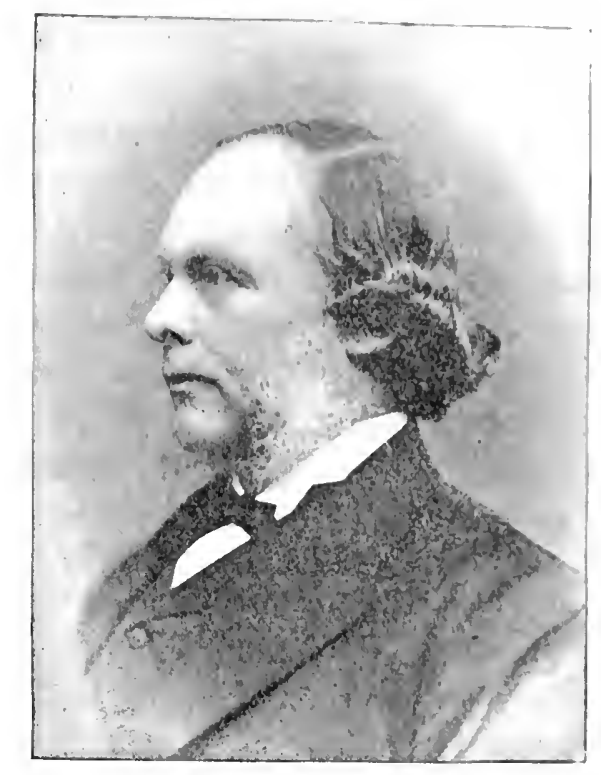

FIG. 56.-LORD Lister, M.I., J.T'I, H.L.I., I'.R.S.

(From a photuserah, )

measure, modified, and that sureons now resort to little, if any, of the paraphernalia which first made it such a formal proceeding, in no regard slatie the scientifie nature of its foundation, but rather have tended ever to corrobolite it and establish it more and more firmly. I,ister bean with the supposition that the air contains the germs which are most active and pernicious in producinger disease. It las been since learned that air-contand is. perluaps. least of all 
to be dreaded. We, howerer, recognize the germs as always the efficient agents, thongh we have since learned that other sources of contamination are much more to be dreaded than air. It had been the custom, "p to Lister's time, to observe usually the ordinary forms of cleanliness, but, not appreciating the multitude of germs which lurk in and about the skin, it had not been customary to scour and prepare it as we have learned to do since lister's day. The ligatures and instruments which were used and the dressings which were applied, as well as the sponges used during the operation, usually went through the ordinary forms of cleansing; and yet Lister's investigations showed the utter inadequacy of such preparation. His most important olject-lesson, however, was that everything that came in contact with fresh or blceding tissues might cary infectious material (i.e., germs), unless it had itself been thoroughly fieed from their presence. Accordingly, the system taught the accurate preparation of everything,from the skin of the patient, which was to be carefully cleansed and shaven, to the hands of the operator, which were to be scrupulously scrubbed, as well as those of every assistant who might handle or touch any of the instruments or dressing materials. It inchuded, also, the careful preparation of sponges, sutures, and ligature materials, all of which were kept protected from air-contact and in antiseptic solutions until the moment of their use. 'The dressing materials were impregnated with substances like carbolic acid, which had been proven to be germicidal; and impermeable material, like oiled silk, was used to cover the surgical dressing, in order that fluids which might leak through should not come in contact with the air, which might permit of their putrefaction, while, at the same. time, air from without could have no access to the deeper parts thus protected.

The original method of Lister was very elaborate, and included also the dissemination throughout the air of the 
operating-room of a vapor of carbolic acid, which was disagreeable, sometimes almost fatal, to operators and bystanders alike,-its use being based upon the notion that the air was the substance most to be dreaded. 'I'he instruments were placed in strong antiseptic solutions, usually carbolic, which were pungent and irritating to the hands of all that came in contact with them. So thoroughly and ubiquitonsly were antiseptic materials employed that it was soon learned that they were of themselves rather injurious to the best interests of the patients upon whom they were employed. Their use, of course, was contingent upon the notion, then everywhere prevalent, that powerful substances must be used in order to counteract the activity of the much-dreaded germs.

In the course of time, however, it was learned that the air was not so much to be dreaded as had been supposed, and that even if it came in contact with raw tissues infection did not certannly follow. It was found also that the antiseptic solutions which had been so freely uscd for irrigating or drenching the parts during an operation were by no means essential, and that tissues often healed better which had not been subjected to so much irritation. It was learned further that it was not necessary to impregnate dressings with these same solutions, providing, in the first place, they were carefully sterilized by the application of heat, which in time came to be used for the purpose of sterilizing everything not injuriously affected by it. In consequence, then, all dressing material, silk ligatures, instruments, nail-brushes, etc., were subjected to live steam or to boiling water for twenty minutes or more, which was demonstrated to be completely effective in the destruction of all organic or bacterial life. This, of itself, was a very great simplification of the antiseptic method. It was also demonstrated that the vital fluids of the animal body had of themselves great germicidal power, and that the strong antiseptic fluids previously used tended rather to 
impair this power than to enlance it. Accordingly, fluids for irrigation came to be used only when there was some noxious material to be washed away. It was found that fresh wounds healed most kindly when least irritated by applications of any kind, providing only that nothing came in contact with them which could infect them. And, in this way, as well as by resort to simpler rather than complicated procedures, there was gradually substituted for the so-called antiseptic method that which is now everywhere recognized, and always practiced, when possible,-i.e., the aseptic method. This simply means that it is very much better to exchude germs than to pernit of their access and then try to kill them after they have lodged. The aseptic method is, therefore, now in rogne, and among the best operators always the so-called dry method of operating, which means that, so far as possible, nothing not absolutely needed at the moment should come in contact with the field of operation. 'This has been, in many respects, a great adrance over the older antiseptic method, though based upon absolutely the same recognition of causes, being only an improvement in technique.

'The benefits of lister's studies, and of that which has grown out of them, are simply incalculable. The surgical infections which, thirty years ago, were the dread of all operating surgeons, have practically disappeared from civil and military hospitals. I esteem myself fortunate in this,that I lave been a living witness of the benefit of change from the old to the new, since when I began my work, in 1876 (over twenty years ago). as a hospital interne, in one of the largest hospitals in this country, it happened that during my first winter's experience,-with but one or two exceptions.-every patient operated upon in that hospital, and that by men who were esteemed the peers of any one in their day died of blood poisoning, while I myself nearly perished from the same disease. This was in an absolutely new building, where expenditure had been lavish; one 
whose walls were not recking with gorms, as is the ase yet in many of the old and well-established institutions. With the introduction of the antiseptic mothod, duringe the two years following, this firghtful mortality was reduced to the average of the day, and in the same institution to-day is done as good work as that seen anywhere. 'The same was true without exception in the great hospitals of the Old World ; and in Paris, where, thinty years ago, famons surgeons would go from one end of the building to the other, landling one patient after another withont ever washing their hands, and where crysipelas and contagion of varions kinds were thoronglyly distributed, as it were, impartially, now the successors of these very same men, enploying modem methods, get results which challenge comparison.

The world has seen few extensive wars since the introduction of the antiseptic system; but, in such as have occurred, its incalculable value in military hospitals has been amply demonstrated. 'The modem soldior is now tanght how to make a prompt occhsive and antiseptic dressing of the wound which he may receive upon the battle-ficld, which, from the moment of its attention, contimues to be treated according to the same enlightened method after he reaches the field-hospital, or when sont to the rear; so that men now receive extensive injuries to joints and to viscera, which previonsly were either promptly fatal, or fatal within a few days from erysipelas and hospital gangrene, from which they recover with useful-often with nearly perfect-limb or function of part restored.

The military hospital of to-day is, therofore, robbed of the terrors which used to make it almost a charnel-house; hospital gangrene, the special dread of active army-surgeons in time past, has almost disappeared from the category of known diseases, and one of the greatest dangers menacing the modern soldier has been removed from modern civilized life. The method has met with universal adoption among 
all civilized races and peoples, and all this through the energy and talent of the originator, now Sir Joseph Lister.

With the recognition of the germ nature of so many acute diseases has come also srstematic study of the use of antiseptics internally; and, while no such exceeding satisfaction has resulted from labors in this direction, we have, nevertheless, learned that most of the infections diseases of the alimentary canal-for example, cholera, typhoid, etc.are well attacked by means of antisepties administered internally; that many of the conditions that depress and annoy are due to the presence of germs in the alimentary canal and the urinary sistem, and are best combated by means which shall remove these agencies, if not destroy them. It has been learned, also, that many forms of skin disease are parasitie, and that these are only successfully treated by the employment of antiseptics externally.

And so the recognition of the germ nature of infectious diseases and the germicidal properties of certain substances, now spoken of as antiseptics, have kept pace, the one with the other; and in consequence the world has reached a period in its medical history never even dreamed of by our forefathers, when the infections diseases have been shown to be practically preventable and, to a large extent, curable by the employment of drugs directed especially against their exciting cause. What the years to come may have in the way of further discovery in this direction, we may not foresee. So far as one can at present see ahead, the next advances must be in the direction either of means which shall fortify the human organism against the inroads of bacteria, or disease-germs, or else in the discovery of substances, snch as we do not yet know, which shall be at the same time poisonous to the germs and innocuons to the patient, to whom they may be administered in doses sufficient for their purpose. Any material possessing these properties would be an ideal antiseptic for internal purposes. At present we only approach our ideal, but are 
very far from its active realization. In no way would mankind be more greatly benefited than by the prosecution of studies which may lead to satisfactory results in either of these directions.

The writer makes no apology liere for having intro. duced two distinct chapters, - one rpon the history of antiseptic smrery, the other upon the history of anasthesia. First of all, they are the two grandest medical discoveries of all time; and, secondly, they are of Anglo-Saxon origin, -the one British, the other American. To the introduction of anastheties and antiseptics is due a complete revolntion of earlier methods, complete reversal of mortuary statistics, and the complete relief of pain during surgical operations; in other words, to these two discoveries the human race owes more of the prolongation of life and relief of suffering than can ever be estimated or formulated in words. What an everlasting disgrace it is that, while to the great murderers of mankind, men like Napoleon in modern times and his counterparts in all times, the world ever does honor, erects imposing monuments and writes volumes of encomiums and flattering histories, the men to whom the world is so vastly more indebted for all that pertains to life and comfort are scarcely ever mentioned save in medical history, while the world at large is even ignorant of their names. For this reason, if for none other, these chapters find an appropriate place in a work of this character. 


\section{CHAP'TER XIV.}

\section{AN EPITOME OF TIL HISTURY OF DENTISTRY.}

Rude Dentistry of l'relistoric Times. Early lnstruments for Extraction Male of Lear. Dentistry on the Sinte Low l'lane as Jedicine luring the Fist Ilalf of the Cluristian kar. Dentistry Taught at the selool of Salemum. Progress of the Art on the Comtinent. l'rosthesis and sulstitutes for Homan Teeth. Introluetion of Loreelain for Artificial Teeth; of Metal and of Vuleanizer liubler for Ilates; of I'laster for Inpressions. From being a Tmule, Dentistry is now a I'rofession, in which Americans lead the World. Statisties.

'TuE following is a synopsis of an uddress delivered at the opening of the session of the Dental Department of the University of Buffalo, in October, 1895. It is appended here because it is certainly apropos of the topics herein considered, the colloquial form being retained.

Called upon at short notice to welcome you here, and to offer remarks of general professional interest, it occurs to me to be retrospective for awhile and to consider the steps by which that which was once an exceedingly cme art has been developed until now it is an exact science. In other words, I would invite your attention, for a time, to the history of dentistry. At a time even before our combined art and science had a definite history we find that gold was used among the Egyptians for the purpose both of filling teeth and of supporting and directing them. In the bodies of many Eryptian nummies, especially of the higher class, there have been found teeth filled with gold or with wood which was covered with gold. It is known, also, that the Hindoos and Egyptians inserted artificial teeth and that some of these were made of wood, often covered with gold, and held in place by gold or silver bancls and wires. Herodotus, who traveled so extensively in Egrpt and wote most entertainingly of his travels, has noted the division of medicine among the Egyptians into special branches and the existence of physicians, each of $(330)$ 
whom applied himself to one disease and not to more. "Some," said he, "are for the eyes, others for the head. other's for the teeth, and others for internal disorders."

It is known, also, that about 300 B.c. Elasistratus doposited in the temple of the Delphian Apollo an orlontogogue, or tooth-foreeps, made of leat, intimating therehy that only those teeth should be drawn which were loose enough to be extracted with such an instrument.

Celsus, who was a contemporaly of C'lurist and of Cesar, was the first to recommend the use of a file within the mouth for the purpose of removing irritating erlges and points of teeth. He also recommended bursting hollow teeth by putting into them pepper-coms, which should absorb moistme, swell, and thus break the teetl in pieces. He also recommended to take particular pains to try to slake or manipulate tecth loose before extracting them.

Galen, about 150 A.D., taught that tectl were true bones and that the canine teeth should be called "eye" teeth, because they were supplied by a branch of the optic nerve. Aëtius, 300 A.D., apparently discovered the formina at the roots of the teeth through which the nerves enter.

In Rome false teeth and sets of teeth constructed of ivory and fastened with gold wire existed as early as the Iaws of the XII Tables, and before the days of Roman civilization it is known that the Etruscans were skilled in manipulation of gold within the montl, while your dean has described and has, I believe, in his possession beautiful examples of Etruscan work of this kind.

Among the Arabs, after the Alabian domination of the then civilized world, attention was paid to the tceth, although this was considered a very inferior part of the physician's work. Among these Arabians much later, and in spite of their study of Greek writers and their translations from the Greek, there may still be met such passages 
as this from Garriopontus, 1045 A.D.: "On the island of Delphi a painful molar tooth, which was extraeted by an inexperienced physician, oceasioned the death of a philosopher, for the marrow of the tooth, which originates from the brain, ran down into the lungs and killed that philosopher." For all that I know, this is the first record of a death after extraction of a tooth. Albucassis, 1100 A.D., gave directions for replacing lost teeth by natural or ivory substitutes. For centuries extraction of teeth had becn and was considered a critical and dangerous operation, although itinerant quacks drew them without hesitation.

The Roman poets and satirists made many allusions, in their day, to the teeth and to operations performed upon thens.

During the Middle Ages the most celebrated medical school that the world ever saw was foumded at Salermum, and was for several centuries the headquarters to which resorted men who desired to study medicine and patients from all parts of the world who desired to be cured of various diseases. It was a farorite stopping-place for crusaders on their way to and from the Orient, and history relates many interesting episodes pertaining to such visits. Under the influence of this school dentistry was more or less cultivated by those who practiced surgery. Brmo, of Langoburo (about 1250), mentions various operations upon the teeth and the antrum, although that was nearly four humdred years before Highmore caretully deseribed this cavity. Johames Arculanus (Giovamni d'Areoli), in the fifteenth century, filled teeth with gold. I must digress for a moment to speak of another suggestion of Arculanus's. Yon know that quite recently the use of the magnet has once more come into rogue among oculists for the remoral of foreign particles of iron or steel from the anterior chamber or the globe of the eye. It was Arculanus who, some five hundred years ago, suggested extraction of iron splinters from the cye by means of the 
attraction of amber electrified by friction. (For School of Salermum see page 72.)

During the sixteenth and seventeenth centuries the French surgeons, especially T)ionis and Verduc, made many practical contributions to dentistry. In 1728 Fanchard wrote in Paris the first complete work on dentistry, -Le Chirurgien Dentiste, on Tiraté ales Dents. Anzolui, of lyons, wrote another. Ise Cluse first mentioned the English turnkey for extraction. Jourdain introduced a number of new and appropriate instruments and new forms of artificial teeth. Bourlet, dentist to the kind, made artificial palates. Porcelain teeth were first introduced in France in 1774.

Among the Germans cosmetic dentistry, thomgl still the farorite field of charlatans, was greatly cultivated. Serré wrote a treatise on Toothache in the Fair Sex During Pregnancy, but the first public dental clinic in Germany was not established until 1855, by Professor Albrecht, and in Vienna. It has been in Tienna, among the Germans, that dentistry has been in time past most honored, and was taught when it was scarcely recognized in the other German universities. Private dental institutions were also first established in Viemma.

Of all the tooth-extracting instruments, the dental forceps in crude form is the earliest, the first on record, perhaps, being that deposited by Erasistratus in the Delphian temple, as already mentioned. For hundreds of years these instruments scarcely changed in shape. It was Garengeot who invented the liey, early during the last centmy. Before that, and for awhile, dentists who had abandoned the foreeps used an instrument known as the pelican,- said to much resemble the skid used by lumbermen.

Before artificial (porcelain) teeth came into use the following substitutes were employed, their estimated value being in accordance with the order in which I name them: 
IHuman teeth, animal teeth, hippopotamus- tusk and teeth, elephant-ivory, and bone.

Humen Teeth.-C'Transplantation of teeth was at one time very common. After being inserted, they were held in place by pirots and ligatures, springs, and upon bases. 'The pirot method also included the use of screws. Liggatures for fastening teeth were made of silli-worm gut,which, now so common in surgery, was ased for this purpose, perhaps, two hundred years ago, - of gold wire, etc. The method by ligatures is the earliest of all. Human teeth have always been more or less expensive if fresh, few people being willing to part with somd teeth except for a money consideration. In 1784 a Philadelphia dentist offered, in an advertisement, two guineas each for sound front teeth.

Animal Teeth.-These were largely used, being held in place the same way as abore, the principal objection being that it was difficult, often impossible, to match human with animal teeth. It was found, also, that the latter decayed very much more easily.

Hippopotamus-izory.-This was at one time rery extensively used. It was carred into the shape of the missing teeth, and was held upon a base; or it was carred into shape as a base upon which to rest human teeth. Most often it was used as a base for piroting. Not infrequently a block was carred out which represented gum, teeth, and all, and partial dentures of this complex type were often so deftly fashioned as to be very realistic, the part representing the grum being colored. Unfortmately no dye nor color in the moutl could be made permanent.

Elephant-ivory.-This was used for the cheaper grades of work, being less durable.

Bone.-Bone was still more objectionable, and was used for only the cheapest work.

Artificial porcelain teeth were first introduced in France in $177 t$ and in America in 1817. Those which were first 
made were so large, awkward, rough, and ill-fashioned, without attempt to represent the gum, as to bear no comparison to the artistic products of to-rlay. 'I'hery were intended for the most part for attachment to ivory bases. The artificial dentures made for George Vishington were of this general eharacter, and, althomgle they called forth his encominms in a letter to his dentist expressing his gratitude, they would pass for very shabby produrtions today. Onc of the greatest advances in dentistry was the introduction of gold bases as a substitute for the baseplates previously made of irory or bouc. 'This is distinctly an American invention, and is to be credited to ciarlette, of Philadelphia, who produced the first bases of this kind in 1787. Since then other metals have been used only becanse cheaper, none having the valuable properties of gold.

Gutta-percha was introduced for this and various dental purposes in Fugland, in 1851, by 'lrucman. In 1851, too, came Goodycar's process of vulcanizing, which the dental profession were at first slow to avil themselves of, but which led, as its value was recognized later, to expensive and almost endless litigation.

Another most valuable American invention was that of taking impressions by the use of plaster. 'This was introduced about $1844-45$. This method permitted the making of socket-plates, which, of itself, was a long step in advance.

So much for a very brief epitome of some of the most interesting facts in the history of dentistry. Did time permit, the matter would warrant treatment at much greater length. But what now is to be said of the condition of dentistry to-day? First of all, that it is no longer relegated to charlatans and itinerants, but is studied, practiced, and honored by men of the ablest minds and of the highest type. There is to-day scarcely any branch of applied science which calls for greater qualifications or for greater 
combination of mental endowment and manual dexterity than does dentistry. We, in New York, find ourselves now in position where the State has assumed not only to regulate the practice of dentistry, but eren to pass upon the qualifications of those who propose to study it. In the assumption of this task by the State there is paid, perhaps, the greatest possible compliment to its dignity and to its importance.

The great field of medicine is now altogether too vast, and the various branches which pertain to it are too complex, to permit a mastery of all its details by any one mind. The man does not live who to-day can be considered facile princeps in more than a few departments of medicine. Life is too short to permit of it, and the study is altogether too extensive. 'There is also a growing public demand for specialization of work, and there is probably more excuse for the perpetnation of dentistry as a specialty than for almost any other branch. Nevertheless, it is necessary constantly to repress a tendency toward a failure to comprehend the general principles underlying all medical specialties, and it lias been hard, at least until recently, to impress upon the men of the dental profession that they were really only practicing a branch of medicine, and that, in disregarding a general and comprehensive knowledge of the findamental branches, they were but poorly preparing themselves for the practice of a dignified specialty. Certainly dentistry makes as many demands for mechanical training, digital dexterity, familiarity with the properties of materials, etc., as does surgery, and in some respects even more. Of course, to a certain extent in these respects it is like a mechanical trade. The great trouble with the dental profession, until very recent times, is that they have regarded their work too much as a trade and not enough as a profession. By taking the latter view of it the work is emobled and their interest for it cultivated. By taling the trade riew of it they have lost those finer features 
which lift mechanical work out of the mere level of a trade. Moreover, men in time past have been guilty of altogether too much trades-mion tacties, which are vehemently opposed to professional ethics, and this has been another feature to degrade rather than elevate dentistry.

This has been indeed a great misfortune, for men have been misled by the need for cultivation of their hands, or their manual powers, and have been persuaded away from a finer study of fundamental principles npon which the whole practice of clentistry should be based. And so it has happened that men have been so ambitions to become perfect operators that they have neglected anatomy, physiology, chemistry, and pathology, have even neglected odontology, sacrificing everything else to their work as mere artificers.

If one scrutinizes the subject properly, there is no reason why there should not grow up a class of men fitted to attend to any lesion of the mouth or of the parts adjoining. In other words, there is no reason why there is not more excuse for true oral surgcons than there is for any other class of specialists, save possibly those who treat the eye. Aural surgery, nasal surgery, pelvic surgery, rectal surgery, etc., are simply voluntary limitations and applications of general surgery to special parts; but he who attends to the teeth has to do so much work of a character which the surgeon is not called upon to perform in any other area, that I have always claimed the oral surgeon deserved a place, as he had a field, by himself. Nevertheless, the knowledge which shall fit a man for such work is not to be obtained in the ordinary dental course, nor in three years of study, even under the best of auspices. The man who would be an ideal oral surgeon must be not only generally familiar with anatomy and physiology, but must thoroughly know the embryology of the face and teeth, the physiology not alone of the organs of the mouth, but of all the secreting glands and the chemistry of all their 
secretions; not only the anatomy of the cranium, but general anatomy as well, and even comparative anatomy. He must be well informed in the explanations of all the congenital defects met about the fiace and mouth; he must be familiar not only with the ordinary principles of pathology and bacteriology, but he will find in the fluids about the mouth such a fertile opportunity for bacteriological study that, be he ever so expert or erudite, he has still much left to investigate in this direction. There is no disease-germ with which he can afford to be unfamiliar, and, as any form of tumor may be found in or about the mouth, he should be familiar with the entire subject of tumors and their surgical treatment.

'Then, again, he must be familiar not only with the physical properties of metals and the various materials used in plastic dentistry, nor expert alone in the operations about the teeth, but, inasmuch as lic las to cope with rarious wounds, injuries, and operations about the soft parts, he must be thoroughly familiar with the principles of wound-healing; with the causes of sepsis and the agents which produce it, and the means of aroiding it; in other words, he must have a general training in operative surgery, and, according to my ideal, which may be high, he should be a man able to do almost any operation in surgery before he limits himself to surgery of the mouth. Unless he have this ability, he will not do such operation as well as a general surgeon can, because the underlying principles are the same, and the latter will have the greater command over them.

When, then, this perhaps ideal man has become thoroughly familiar with the principles of surgical anatomy, operative surgery, surgical pathology, and bacteriology, in addition to the things already mentioned, then, and not until then, may he and should he assume to operate for harelip, cleft palate, cancer of the tongue, and various other lesions in the parts about the mouth. 
I wish I could say and demonstrate more to impress upon you the important bearing of modern sulgeical pathology to dentistry. Perhaps I can give you no better illustrations than you can see in the studies and writing of Prof. W. I). Miller, of Berlin, of whom I am promel to sily that he is an American, and that he is the only American occupying a professorship in a German morrersity. In his studies on the causes of dental caries and mpon the bacteria of the month lie has identified and named nearly a hmudred species of the bacteria, many of which he has shown to be the active causes of dental decay. Ile las done, then, for dental pathology in this dircetion what other eminent observers have done for the processes of suppuration and ulceration in other textmes and tissues, and has helped to show that they are all evidences of pernicious germ activity. By his rescarches, also, upon inflammation in elephant-tusks, and the results of injury, mainly by bullet wounds, he has shown us that the phenomena attending these changes in dental tissnes are practically identical with those in bone. His researches have done very much to explain the pathology of that common discase, pyorrhwa alveolaris, which is linown to be but one expression of local infection, while the possibility of migration of infectious organisms and of metastatic lesions in other parts of the body, having their origin in infections discase in or near the teeth, has been brilliantly demonstrated by his interpretation of well-known clinical facts.

That American dentists are most highly regarded abroad is more than a matter of every-day knowledge. It has got to be so now that a foreigner will purchase instruments of American makc, and then advertise himself as an American dentist for the purpose of getting business, -a purpose in which, as a rule, he is quite successful. But let me stop here to do honor to another American dentist who is more highly honored abroad than one ever can be at home, and of whom it might be said, perhaps, 
that he has had more friends among the rovalty and nobility of Europe than any other man of his time. This is Dr. Evans, who has lived for years in Paris, who was the personal friend of Nipoleon III and the trusted gruide and companion of the Empress Eugenie when she fled from Paris. While it may be said of him that the qualities that made him so unirersally popular were personal qualities, rather than professional knowledge, it must be said in reply that it was his eminent professional attainment which first brought him such influential friends.

But time presses, and I want, before closing, to say a little about dentistry in America. It was about 1835 that Dr. Hauris, then residing in Baltimore, though born near Syracuse, conceived the modern idea of the scope and practice of dentistry. He was ambitious to put the dentists of his time upon a higher professional level, and to make of dentistry a specialty in medicine. He applied to various medical schools to found dental chairs, and to teach oral pathology along with dental mechanics, as one of the branches of medicine, the graduating degree to be M.D., as with other medical specialties. But the men of his time were so short-sighted and of such constricted mental calibre, and the dentists were so meducated, that the Baltimore schools declined. He therefore established a separate school, being forced to take this step. This school was the Baltimore College of Dental Surgery, established in 1839 , - the first in any comntry. The dentistry of that day was crude, and its teaching was comparatively inefficient. It was not until six years later that the next, the Cincimnati College of Dental Surgery was organized,-in 1845. 'Then, in time, followed Philadelphia. But all these colleges were separate institutions, teaching only those branches which it was held necessary that a dentist should know and having very little of medicine in their curriculum. They conferred the degree of D.ID.S.

In 1868 Harvard University did what she ought to 
have done at the ontset. She opened a dental department and began the teaching of dentistry as a branch of medicine, establishing therefor a separate degree,-D.M.I).,-Denturia Medicina Doctor. In 1874 the University of Michigan established a dental department, and a little later the University of Pennsylvania did the same. 'I'hese university schools gave an immensely widened scope to the study, which was made broader with each succeeding year.

There are now forty-five dental colleges in the United States. Forty of these are members of the National Association of Dental Faculties, organized for the purpose of securing uniformity in teaching and in graduating men. Membership in this association is a certificate of high standing and of comprehensire advantages.

Last year (1894) the number of students in dental colleges was 4979, while the number of graduates was 1208 . At present nearly all the States have legislation governing the practice of dentistry, and often more strict than that regulating the practice of medicine. In New York the law places dentistry on precisely the same plane as medicine,-prescribes the same qualifications for matriculation, the same length of study, exactions for graduation, examination, etc. In other words, the law is quite as strict regarding admission to dental colleges as to medical. After 1897 at least a full high-school course will be demanded for matriculation, and from now on we may look forward to having a really educated dental profession. 


\section{C'IIAPTER XY.}

\section{IATROTHEL'RGIC SIIIBOLISM.}

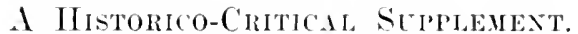

AtTExtios is invited in this supplementary chapter to a subject which has alwars been of the greatest interest to the writer, yet 11 on which it has been diflicult, without great labor and numerons books, to get much information. II I were to attempt to formulate this topic under a distinctive name I combl. perhapes call it Medico-Christian siymlolism. It is well known to scholars that practically all of the smbols and smbolism of Christimity lave come from pagan sources, haring been carricel over, as one might say, across the line of the Christian era. from one to the other. in the ninst natural and mavoidable way, though mont of these srmbols and caricatures have more or less lost their original signification and have been griven another of purely Christian import.

'To acknowledge that this is so is to cast no slur upon Christianity; it is simply recording a historical fact. It would take me too far from my purpose were I to go into the events which have brought about this change: I simply want to disavow all intention of making light of serious things, or of reflecting in any way upon the nobility of the Cluristian Church, its meanings, or its present practices. But, accepting the historical fact that C'hristian symbols were originally pagan caricatures, we must study the original signification of these pagan symbols, especially since it can be shown that almost all of these emblems had originally an esentially medical significance, referring in some way or other either to prestions of health and disease, or: see to the deeper question of the origin of mankind and the great generative powers of nature, at which physicians wonder to-day as mull as they dirl two thonsand years ano. Considering, then, the medical significance of such sturly, I have been tempted to ineur the charge of being pedantie and have coined for it the term Iatrotheurgic Symbolism. 
As Inman says, Moderns who have not bero initiated in the sacered mysteries and only know the amblems comsiderent salcerl, hate nerel of hoth anatomieal knowledge and physiological lore cre they cand sere the meaning of many signs. 'The emblems or symbols, llow, fo whichl

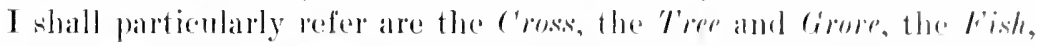
the Dove, and the serpenl. And tirst of all the choss, alsont whichl very erroneons notions preval. It is seren everywhere cithor ats a matter of personal or church adormment, or as an arehitectmal feature, and everywhere the impresion prevals that it is exchusely a charistian symbol. 'This, howerer, is the grossent of errors, for the worled aloumds in cruciform symbols and monuments which existed long before Christianity was fombled. It is otherwise, howerer, with the Crucilix, which is, of eourse, an absolutely ('hristian symbol. 'The image of a dead man stretched ont upon the coros is a purely ('hristian ardition to a purely pagan emblem, though some of the old llinden crosses remind one of it very powerlully. Xo matter npon which continent we look, we see everywhere the same cruciform sim among peoples and races most distinct. There, perhaps, has never been so miversal a symbol, with the exception of the serpent. Moreover, the cross is a sort of international feature, and is spoken of in its modifications as St. Andrew's, St. Geolge's, the Maltere, the Greck, the Latin, ete. Probably beeause of its extreme simplicity, the ages have brought but little change in its shape, and the hauble of the jeweler of to-day is practically the same sign that the aneient bigyptian painted upon the mummy-cloth of his sacred dead. Thus it will appear that the shadow of the cross was cast far hace into the niglit of ages. The Druids eonsecrated their sacred oak by cutting it into the shipe of a cross, and when the natural shape of the tree was not sullicient it was pieced out as the case required. When the Spaniads invaded this continent they were overeome with surprise at finding the sign of the cross everywhere in common use. It was ly the community of this emblem between the two peoples that the spaniarts enjoyed a less warlike reception than would otherwise have been accorded to them.

That the cross was originally a phallic emblem is proved among other things by the origin of the so-called Maltese cross, which origimally was carved out of solid granite, and represented hy fom huge phalli springing from a common center. which were afterward changed by the Knights of St. John of Malta into four triangles meeting at a central globe; thus we see combined the simbol of eternal and the cmblem of eonstantly-renorating life. The reason why the Maltese 
cross had so distinctly a phallic origin, and why the Knights of St. John saw tit to make smething more lecent of it, is not clear, but a study of Assyian antiquities of the days of Nineveh and Babrlon shows that it referred to the four areat gouls of the Assyian Pantheon, and that with a dhe setting it signifies the sun ruling both the earth and the hearens. Schlieman discosered many examples of it on the valses which he exhmont from the ruins of Troy.

lint problibly the most remarkable of all croses is that which is exceerlingly common upun Egytian momments and is known as the C'ruir-anseta.- that is. the hambled cross--which consisted of the orlinary (ireek Tau, or cross, with a ring on the top. When the Egyptian was asked what he meant hy this sign he simply replied that it was a divine mystery, and such it has larecely remained ever since. It was constantly seen in the hands of Isis and Osiris. In nearly the same shape the spaniarls formd it when they first came to this continent. The natives said that it meant "Life to come."

In the British Mnsem one may see in the Asprian galleries effigies in stone of certain kings. from whose necks are slispended senlptured Maltese eroses. such as the catholics call the ".pectoral C'ross." In Egypt. long before C'hrist, the sacred llsis was represented with human hands and feet. holding the statf of $I$ sis in one hand and the cross in the other. The ancient Eerptian and astronomical signs of planets contained numerous croses. Satum wa represented by a cross surmounting a ram: horn. Jupiter by a cros beneatle a horn. Temus by a cross beneath a circle (practically the (rux-ansata). the earth by a cross within the circle. and llars by a circle leneath the cross; many of these signs are in use to-day. Between the buthlust crosses of lndia and those of the Roman chureh are remarkalble resemblances: the former were frequently placed upon a calvary, as is the Catholic custom to-day. The cross is found among the hieroglyphies of China and upon Chinese pagodas, and upon the lamps with which they illuminated their temples. Cpon the ancient Plocenician medals were inscribed the cross. the rosary, and the lamb. In England there has been for a long time the enstom of eating the so-called Ilot-Cross Buns upon Good Friday: this is no more than a reproduction of a cake marked with a cross. which used to be duly offered to the scrpent and the bull in heathen temples. as to living idols. It was made of flour and milk, or oil, and was often eaten with much ceremony by priest: and people.

Perhaps the most ancient of all forms of the cross is the cruci- 
cross, for all portions of this structure constituted the most universally acceptid symbol of sex in the world."

As perfectly consistent with the ancient doctrine that deity is both make and female, take this thought from Proclus, who quotes the following among other Orphic rerses: "Jupiter is a man: Jupiter is also an immortal maid": while in the smme commentary we read that "all things were entained in the womb of Jupiter."

In this connection it was quite customary to depict Jupiter as a female, sometimes with three heads: often the figure was drawn with a serpent and was renerated under the symbol of fire. It was then alled Mythra and was worshipped in secret caverns. The rites of this worship were puite well known to the Romans.

'The hermaphrodite element of religion is sex worship: gods are styled, he, she. Synesius gives an inscription on an Egyptian deity: "Thou art the father and thou art the mother; thou art the male and thou art the female." Baal was of uncertain sex, and his votaries usually invoked him thus: "Hear us, whether thou art god or godless." Heathens seem to have made their gods hermajhrodites in order to express both the enenerative and prolific virtues of their deities. I have myself heard one of the finest living Ilindoo scholars. a convert to Christianity. invoke the God of the Christian Church both as father and as mother.

The most significant and listinctive feature of nature worship certainly had to do with phallic emblems. These, viewed in the light of ancient times, simply represented allegorically that mysterious mion of the male and female principle, which seems necesary to the existence of animate things. If in the course of time it sadly degenerated, we may lament the fact. while, nevertheless, not losing sight of the purity and exalted character of the original idea. Of its extensive prevalence there is ample evilence, since monuments indicating such worship are spreal over both continents and have heen recognized in Egypt, India. Assyria, Western Europe, Mexien, Peru, Hayti, and the Pacifie Lslands. Without douht the generative act was originally considerel as a solemn sacrament in honor of the Creator. As Knight has insisted, the indecent ideas later attached to it, paradoxical as it may seem, were the result of the more adranced civilization, tending towarl its decline. as we see in Rome and Pompeii. Toltaire, speaking of phallic worship, says: "Our ideas of propriety lead us to suppose that a ceremony which appears to us so infamous could only be inrented by licentionsness, but it is impossible to believe that deprarity 
of manners would ever learl among any people to the establishnumt of religions ceremonies. It is probalste, on the contrary, that this custom was first introduced in times of simplicity, and that the first thought was to homor a deity in the spmbol of life which it give las."

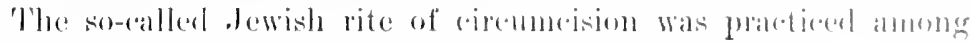
Egyptians and Plandedans lomg hefore the hirth of Abraham. It had a marked religious significance, being a sign of the forenant, and

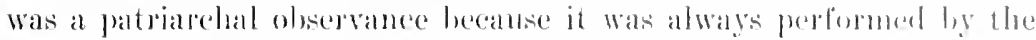
head of the lamily. Inteed, on the anthority of the linke, we learn that this was the ase, also, even among the primitive dran people.

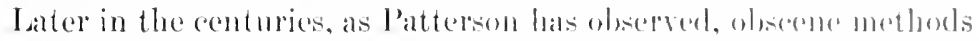
beame the principal feature of the popular superstition, and were, in atter-tines, even extenderl to and intermingled with shomy rites

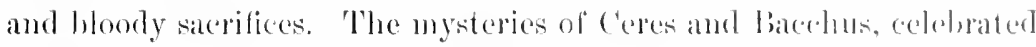
at Bleusis, were probably the most ectebrated of all the (irecian observances. The adrlition of bacehus was complatively a late cme, and this name liacehus was first speelled latechos; the first half. Iao, being in all probability related to far, which alplears in Jupiter or Jovispater, and to the Jehrew Yalue, or Jehovilh. fao was the harvest-god, and consequently the god of the grape: hene his elose relation to Bacehus. How completely these Elensinian myteries legenerated into bacchic orgies is, of course, a matter of written history.

I have not yet refered to the reverence paid to the Fish, both as a phallic emblem and as a Christian symbol. The supposition that the reason why the fish played so large a part in early ('hristian symbolism was beeause of the fact that ach letter of the cireck word Iethus could be made the begimning of words which. when fully spelled out, read Jesus Christ, the Son of (iod, is altogether ton far-fetcherl; though, if it be true, it is a scholastic trick to juggle with words in this way rather than to find for them a proper signifiention. Imong the Egyptians and many other nations, the greatest reverence was paid to this animal. Among the natives, the rivers which contained them were esteemed more or less sacred: the common people dirl not feed upon them, and the priests never tastod them. hecanse of their reputed sanctity, while at times they were worshiped as real deities. Cities were named after them, and temples built to them. In different parts of Egypt different fishes were worshippen individually: the Greek comedians even made fun of the Egrptians heause of this fact. Dagon figures as the Fish-god, and the female deity known as Lthor. in 
Firyt, is undoubtedly the same as . Iphrodite of the Greeks and Tenus of the Romans. Who were believed to have sprung from the sea. lucian tells ws that this worship was of great antiquity. Strange as this delolatry may appear, it was yet most wide-spread, and ineluded also the rencration which the Egyptians, herore Moses, paid to the river Nile.

It is important to remember that Xun, the name of the father of Johna. is the semitic word for fish. while the phallic character of the fish in Chaldean mythology cammot be gainsaid. Nim, the planet siturn. Was the linh-god of lierosns, and the same as the Assrian god Asshm, whose name and oflice are strikingly similar to those of the Hebrew leater Joshua.

corresponding to the ancient phallus. or lingam, which was the masculine phallic simbol, we have the Kieis, or Yoni. as the symbol of the female principle: but an emblem of similar import is often to be met with in the shape of the shell. the figr-leaf, or the letter delta, as may he frequently seen from ancient coins and monuments. Similar attrilutes were at other times expresed by a bird. using the dove or starrow. which will at once make one think of the prominence given to the dove in the fable of Toah and the Ark. Referring again to the fish-simbol, let me say that the head of l'roserpine is rery often represented surrombled hy dolphins: sometimes by pomegramates, which also have a phallic significance. In fact. Inman in his work on "Ancient Faiths" says of the pomegranate: "The shape of this fruit mueh rembles that of the gravid uterus in the female, and the abmulance of seeds which it contains makes it a fitting emblem of the prolifie womb of the celestial mother. Its nse was largely arlopted in varjous forms of worship: it was mited with bells in the adormment of the robes of the Jewish high-priest: it was introluced as an ornament into.tolomon: Temple, where it was united with lilies and with the lotus."

lts arcane meaning is undouldedly phallie. In fact, as Inman las stated. the idea of virility was most closely interwoven with religion, though the English Egyptologist: have suppressed a portion of the facts in the history which they have given the world; but the practice which still olutains among the negroes of Northern Afriea, of mutilating every male captive and slain enemy, is but a continuance of the practice mentioned in II Kings, xx, 18; Isaiah, xxxix, 7 ; and I samuel, xriii. : 6 .

Frequently in sacred scripture we find reference to the pillar as 
a most sacred mublem; as, for eximple, in I-ilials, xix, 1!) "In llat day there shall lee an altal to the land in the midet of the land al

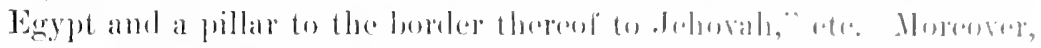

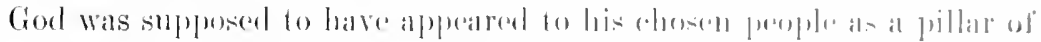

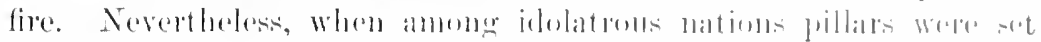

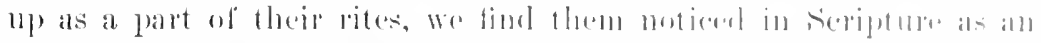

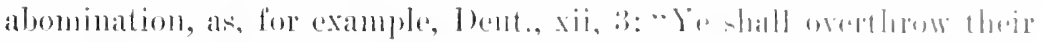

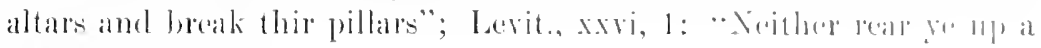
stancling image:"

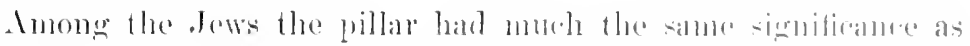

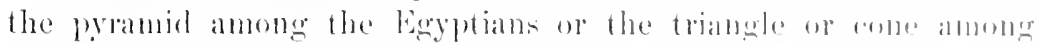

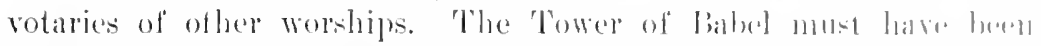
pmely a mythical ereation, but in the same discetion. Although

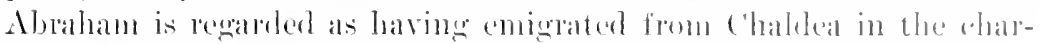

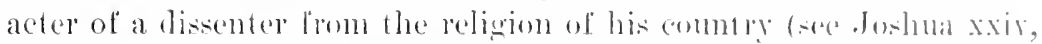

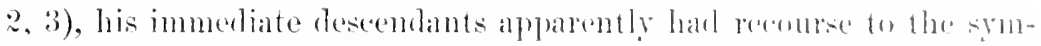
bols which l have mentioned. 'Thus he erected altals and planterl pillars wherever he residod, and condueted his som to the land of Moriah to sacrifice him to the deity. as was dome among the l'hurnicians. Jeptha in like mannel sacrificed his own damehtor Mizpels and the Temple of solomon was supposed to have heen huilt upon the site of Abraluams ancient altar. Jacols not only set ule a pillale at the place which he called liethel, but mabe libations: sammel worshipped at the high places at liamah. and solomon at the (iveat stome in Ciibeon. It remained for Hezekiah to change the entile Ilubrew cult. He remored the loionysiac statnes and phallic pillars, as well as the conical and omphallic symbols of Tenus and L shtaroth, and broke in pieces the brazen serpent of Moses and orerthew the momd: and altars. After him . Toshua removed the paraphernalia of sum worship and destroyed the statues and emblems of Venus and Idonis (II Kings, xxiii, $t$-?0).

The Greek IIermes was identical with the Figytian Lihem, as well as with Meren'y and with Priapns: also with the IIelorew Eloah. Thus, when Jacob entered into a covenant with Lahan, his father-inlaw, a pillar was set up and a heap of stones made and a certain compact entered into; similar landmarks were usmal with the Greeks and placed by them upon public roads.

Is Mrs. Childs has beautifully said: "Other emblems roemed sacred by Hindoos and worshipped in their temples have brought moon them the charge of gross indecencies. . . . If light, with its grand 
revealings, and heat, making the earth fruitful with beaty, exeited womler and worship anong the first inhabitants of our world, is it strange that they likewise regarded with reverence the great mystery of humam birth: Were they innure thus to regard it: Or are we impure that do not so regard it?"

C'onstant, in his work on lioman Polytheism, says: "Indecent rites may be practiced by religions people with the greatest purity of heart; but when incerelulity has gained a footing anong these peoples, then those rites hecome the camse and pretext of the most revolting eorruption."

The phallic symbol was always found in Temples of Siva, who correspombs to baal, and was milully placed, as are the most precions emblems ol' our Christian temples to-day, in some inmost recess of the sanctuary. Horeover, lanps with seven lranches were kept burning before it, these seren-branched lamps long antedating the golden camdlestick of the Mosaie Tabernacle. The Jews by no means escaped the objective eridence of phallic workip; in Ezekiel, xvi, 1\% is a very marked reforence to the manufacture by Jewish women of gold and silver philli.

As a purely phallic symbol and custom, mark the signifieance of certain superstitions and practices even now prevalent in Great britain. Thus, in Buylase's Jfistory of Cornwall, it is stated that there is a stone in the Parish of Marton with a hole in it fourteen inches in diameter, through which many persons creep for the relief of pains in the back and limbs, and thromgh which children are drawn to cure them of rickets. this being a practical applieation of the doctrine of regeneration. In 1888 there was printed in the London Standard a consideralsle reference to passing children through clefts in trees as a curative measure for certain physical ailments. The same praetice prevails in Brazil and in many other places, and within the present generation it has been eustomary to split a roung ash-tree, and, opening this, pass through it a child for the purpose of euring rupture or some other bodily ailment.

The phallic element most certainly cannot be denied in Christianity itself, since in it are many references which are unmistakable to the initiaterl. From the fall of man, with its serpent-myth and its phallie fommation, to the peeuliar position assigned to the Virgin Mary as a mother phallic referenees abound. Howerer, it should not be forgotten that whatever were the primitive ideas on which these dogmas were based, they had been lost sight of, or had been received in 
a fresh aspect by the fommlers of Christianity. The fish and the (Post originally typilied the idea of generation, and latter that of lifo, in which sense they were appliend to C'hrist. The most plainly platlic

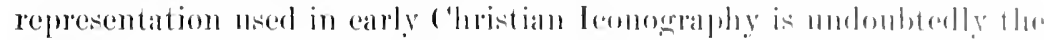
Aureole, or alliptical frame-work, contanining nistally the figntre of Christ, sometimes that of Mary. 'T'he Ximbur, also, generally eirenlar', but sometimes triangular, is of positive phallie signifienture erent thomgh it contains within it the nane of efehosals. 'T'he muflowers, which sometimes are made to smromml the figme of st. John the Evangelist, are the lotus-flowers of the ligyptians. 'Tho livine hamel, with the thuml, and two fingers ontstreteherl, aren thengh it rosts on a crneiform nimbus, is a phallie emuluem, and is used by the Neapolitans to-rlay to avert the Evil bye, although it was oriminally a symbol of Isis. Indeed, the Virgin Mary is the ancient Lis, als cant be most easily established, sinee the virwin "succeeded to her form, tifles, symbols, rites, and ceremonies" (King). The great image still moves in procession as when Jurenal langhed at it, ancl her properer title is the exact translation of the sansklit, and the equivalent of the modern Madonna, the Lotus of Jsis, and the Lily of the molem Mary. Indeed, as King has written: "It is astonishing low much of the Egyptian symbolism passed orer into nsiges of the following times. The high eap and hooked stafl of the god became the bishoplis mitre and erozier. The term Nun is purely Egrptian, and bore its present meaning. The Crux-ansata, testifying the mion of the male and female principle in the most obvious manner, and denoting fecundity and abundanee, is transformed by a simple inversion into an orb surmounted by a cross, the ensign of royalty."

The teaching of the Romish Church regarding the Virgin Mary shows a remarkable resemblance to the teachings of the ancients concerning the female associate of the trime deity. In ancient times she has passed under many and diverse names: she was the Virgin, conceiving and bringing forth from her own inherent power: she was the wife of Nimrod; she has been known as Athor, Artemis, Aphrodite, Venus, Isis, Cybele, etc.

As Anaitis she is mother and child, appearing again as Isis and Ilorus; even in aneient Mexico mother and child were worshipped. In modern times she reappears as the Virgin Mary and her son: she was queen of feeundity, queen of the gorls. goddess of war. Tirgin of the Zodiac, the mysterions Virgin "Time," in whose womb all things were born. Although variously represented, she has heen usually 
pietured as a more or less nude figure carrying an infant in her arms. (Inman, "Ancient Faiths.")

Inman declares without hesitation that the trinity of the ancients is uncuestionalhy of phallic origin, and other's have strenuonsly contemed and alplitrently proved that the male emblem of generation in divine ereation was three in one, and that the female emblem has always been the triangle or accepted symbol of trinity. Sometimes two triangles have been combined. forming a six-rayed star. the two together being emblematical of the mion of the male and female principles producing a new figure; the triangle by itself, with the point down, typifies the delta, or yoni, through which all things come into the world.

Another spmbol of deity among the Indians was the Trident, and this marks the belief in the l'rinity which very generally prevailed in India among the Ilindoos. Is Maurice says, "It was, indeed, highly proper and strictly characteristic that a threcfold deity should wieh a triple scepter." ¿jon the top of the immense pramids of Deogur, which were truncated, and upon whose upper surface rested the circular cone-that ancient cmblem of the Phillus and of the Sun-was found the trident seepter of the Greek Neptune. It is said that in India is to be found the most ancient form of Trinitarian worship. In Egypt it later prevailed widely, but scarcely any two States worshipped the same triad, though all triads had this in eommon, however, that they were father, mother, and son, or male and female, with their progeny. In the course of time, however, the worship of the first person was lost or absorbed in the second, and the same thing is prevalent among the Christians of to-day, for many churches and institutions are derlicated to the second or third persons of the Trinity, but none to the first.

The transition from the old to the new could not be effected in a short time and must have heen an exceelingly slow process; therefore we need not be surprised to be told of the ancient worship that after its exclusion from larger places it was maintained for a long time by the inhahitants of humbler localities; henee its subsequent designation, sinee from being kept up in the villages, the pagi, its votaries were designated pagani, or pagans.

Even now some of these ancient superstitions remain in recognizable form. The moon is supposed to exert a baneful or lucky influence, aceorling as it is first riewed: the mystic horseshoe, which is a purely uterine symbol, is still widely employed; lucky and unlucky 
days are still regarded; om playinger cards are indiratm he phallic symbols, the spade, the tradie chlh, the omphallic distalf and cminence

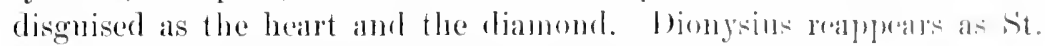
Denys, or in France as St. Baceluss: Siatan is revered, as St. Satur of St. Swithin; the Iloly Virgin Astrad, whoce return Wits heralded l,y Virgil as introducing the golden age, is now designated ats the likesied Virgin, Queen of Heaven; the mother and dhild alle to-day in ('atholic comntries adored as much as were ceres and liacchus, or lois amel the inlant Ilorus centuries ago. The (Christian nums of to-ray are the nums of the Buddhists or of the legytian workippers of l.tis, and the plallie import is not lost even in their "ase, sinee they are the "liricles of the Savionr." The libations of human blom which were formerly offered to Bacelus, found most tragic imitation in the sacriljees of later days. 'The screechings of the ancient prophets of lial, and of the Egyptian worshippers, preceled the flagellations of the penitents. Even recently, during lloly lleek in Rome, devotees lash themetres until the blood runs, as did the foumg men in ancient lione during the Lupercalia. In the ancient lioman catacombs are fomm portraits of the utensils and furnitmre of the ancient mysteries, and one drawing shows a woman standing before an altar offering buns to a certain god. In fact, we may say there is no Christian fast nor festival, procession nor sacrament, custom nor example, that does not come from previous paganism.

Since the dawn of written history, and from the most remote periods, the Serpent has been regarded with the highest rencration as the most mysterions of living creatures. Being alike an object of wonder, admiration, and fear, it is not strange that it became early connected with numerous superstitions; and when we remember how imperfeetly understood were its hahits we shall not wonder at the extraordinary attributes with which it was invested, nor perhaps even how it obtained so general a worship. Thus, centuries ago, IIorapollo, referring to serpent-symbolism, said: "When the Egyptians were representing a universe they delineated the spectacle as a variegated snake devouring its own tail, the seales intimating the stars in the universe, the animal being extremely heary, as is the earth, and extremely slippery like the water; moreover, it every year puts off its old age with its skin, as, in the universe, the recurring year effects a corresponding change and becomes renovated, while the making use of its own boly for food implies that all things whaterer which are generated by divine providence in the world undergo a corruption in to them again." 
In all probability the annual shedding of the skin and the supposed rejurenation of the animal was that which first connected it with the idea of eternal succession of form, subsequent reproduction, and dissolution. 'This doetrine is typified in the notion of the succession of ages which prevailer among the Greeks and the similar notions met with among nearly all primitive peoples. The ancient mysteries, with lew or perhaps no exceptions, were intended to illustrate the grand phenomena of nature. The mysteries of Osiris, lsis, and IIorts in Egght; of Cybele in l'hryeia; of Ceres and l'roserpine all Elensis; of Venus and Adonis in Phonicia; of bona Dea and of Priapus in Rome, all han this in common, that they both mystified and typitied the creation of things and the prepetuation of life. In all of them the serpent was comspicuonsly introduced, as it symbolized and indicaterl the invigorating energy of nature. In the mysteries of ceres, the grand seeret which was eommunieated to the initiates was put in this enigma: "The bull hals begotten a serpent and the serpent a bull," the bull being a prominent emblem of generative force. In ancient Egrpt it was lisually the bulls horns which served as a symbol for the entire animal. When with the progress of centuries the bull became too expensive an animal to be commonly used for any jurpose, the ram Was substituted; hence the frequency of the rams horn as a smmbol for Jore, seen so frequently, for example, among Roman antipuities.

Originally fire was taken to be one of the emblems of the sun, and most naturally, inevitalbly, and universally the sum came to simbolize the active, vivifying principle of nature. 'That the serpent should in time typily the sance principle, while the exg symbolized the more passive or feminine element, is equally certain, hut less easy of explanation: indeed, we are to recard the serpent as the symbol of the great hermaphodite first principle of nature. "It entered into the mythology of every nation. consocrated almost crery temple, symbolized almost every deity, was imagined in the heavens, stamper on the earth, and ruled in the realms of eternal sorrow."

The close relationslip, if not alsolute identity, among the early races of man between solar, Phallic, and Serpent worship was most striking; so marked, indeed, as to indicate that they are all forms of a single worship. It is with the latter that we must for a while concern ourselves. How prominent a place serpent worship plays in our own Old Testament will be remarked so soon as one begins to reflect upon it. The part played by the serpent in the biblical myth concerning the origin of man is the first and most striking illustration. In the 
cens. or Liod of . Esculapins-or in the crown placed upon the head of many a god or godkess, or the many-headed snake drinking from the jeweled cul, or a smake twisted around a tree with another approaching it, sugeresting temptation and fall, the molerlying principle is always the same. Symbols of this character are met with not only in the temples of aneient Egypt. but in ruins anterlating them in Persia and the East: in the antiquities belonging to the rales that first peopled what is now direece and laty, in the Rock-markings of India and of Contral burnee, in the Crumlechs of Creat liritain and soandinaria. in the (ireat serpent Iloumd which still remains in (thio, and in many other momuls lelt by the momel-bulkers of this comntry in the ruins of central America and lucatim, and in the traditions and relies of the Aztecs and Toltecs: in fact. wherever antiquarian research has penetrated or where monuments of ancient peoples remain. There never has been so wide-spread a superstition, and no matter what later forms it may have assumed. we must admit that it. first of all and for a long time. was man's trilute to the great. all powerful, and unknown regenerative principle of nature, which has been deified again and again, and which always has heen. and probably always will be, the greatest mystery within the ken of mankind.

"This religion, void of reason, entemned in the wisdom of Solomon. probably survived eren the babylonian captivity: certainly it was adopted by the sects of Christians which were known as Ophites, Gnostics, and Nicolaitans."

The Creation is, in fact, a human rather than a livine product in this sense: that it was suggester to the mind of man ly the existence of things. while its method was. at least at first. sugrested by the operations of nature; thus. man saw the living birt emerge from the exg, after a certain period of inculation, a phenomenon equivalent to actual creation as apprehented by his simple miml. Incubation obviously, then. associated itself with Creation. and this fact will explain the universality with which the eger was received as a symbol in the earlier system of ensmogony. By a similar process creation came to be symbolized in the form of a phallus, and so the Egyptians, in their refinement of these illeas, adojted as their symbol of the first great eause a scarabaus, indieating the great hermaphrodite unity, since they believed this insect to be both male and female.

They beatifully typified a part of this idea, also, in the adoration which they paid to the water-li]y, or Lotus, so generally regarded as sacred throughout the East. It is the sublime and beautiful symbol 
which perpetually oceurs in Oricutal mytloblocre and, as Maurice stated, not without substantial reasom, for it is its own beantiful

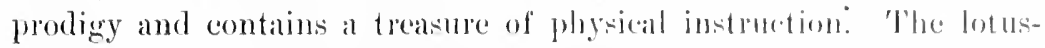

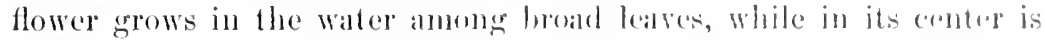
formed a seed-vessel shated like a hell, punctured on the top with small cavities in which its seeds derelop; the openimes indo the serel-

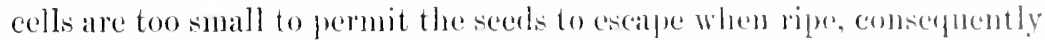
they absorb moisture and develop within the sane, shooting forth as new plants from the place where they originated; the bullo of the vessel serves as a matrix which shall nomrish them motil they ance larese enough to burst open and release themselves, alter whith they take root wherever deposited. "The plant, therefore, being itself" probluctive of itself, vegetating from its own matrix, being fostered in the carth, was naturally adopted as a symbol of the productive power of raters mpon which the ereative spirit of the Creator acted, in giving life and regetation to matter. We aceorlingly find it employer in every part of the Northern IIenisphere where symbolical religion, improperly called idolatry, existed."

Further exemplification of the same molerlying principle is seen in the fact that most all of the ancient deities were paired; thus we have heaven and earth, sun and moon, fire and carth, lather and mother, ete. Faber says: "The ancient l'agans of almost every part of the globe were wont to symbolize the workd by an egas: hence this symbol is introduced into the cosmogonies of nearly all mations, and there are few persons, even among those who have mate mytloology their study, to whom the mundane egg is not perfectly familiar; it is the emblem not only of earth and life. hut also of the universe in its largest extent." lu the island of Cypress is still to be seen a gigantic egg-shaped rase which is smposed to represent the mumane or Orphic egg. It is of stone, measuring thirty fect in circumforence, and has a semlptured bull, the emblem of productive energy, which is supposed to signify the constellation Taurus, whose rising was connected with the return of the mystic reinvigorating principle.

The work of the mound-builders in this comtry is generally and widely known; still it is perhaps not so generally known how eommon upon this continent was the general use of the serpent-symbol. Their remains are spread over the country from the sources of the Alleghany in New York westward to Iowa and Tebraska, to a considerable extent through the Mississippi Talley and along the Susquelianna as far as the Talley of Wyoming in Pennsylvania. They are found even along the 
St. Lawrence River: thery also line the shore of the Gulf from Florida to Texas. 'Thalt they were ereeted for wher than defensive purposes is mont eleall: without knowing exallety what was the gerermment of their holelers, the premmention is that it combined both the priestly and eivil funetions, als obtained centmries ang in llexico. The Great

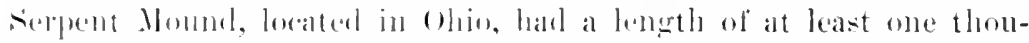
sallul feet: the outline was perfectly regulalr and smosth, and the momth was wirlely ofretl. als it in the ale of swallowing or ejecting an oval tigure, also formed of earth. whose lomgest dianeter was one homdreel and sixty leet. Igain, near (iranville, (1)hen, aecers the form of an alligaters in connection with which was indulitable evidence of an altar. Noar 'Tarltom, Ohin, is another anth-work in the form of a cross. Tluere is erery reason to think that sacrifices were made upon the altars nearly always fomnd in comnection with these mounds. Amone the varions anmal engeres fomm in Wisconsin, mounds in the form of selpents are most frequently met with, while cireles inclosing a fentagon or a momol with eight rarliating points, moloubtedly representing the sun, were also fomml.

There womld seen, in all these representations, to be an unmistakable reference to that form of andy cosmogrony in which erery vivificatiom of the mumtane exor connstituter a real act of creation. In Japan llis comeeptive egg is allegorically represented ly a nestecgr shown floating upon an expanse of water, against which a bulb is striking with horms. The Sandweh lsknters have a tradition that a bird. which with them is an emblem of deity, lait an egg upon the waters, which lurst of itself and thes produced the jalanels. In Egypt, Kneph was representerl as a serpent emitting from his month an exg, from which proceds the divinity Platha. In the Bible there is frepuent reference to seraphs: se Ra Plo is the singular of seraphim, meaning splendor, fire, or light. It is emblematic of the fiery sun, which moder the name of the serpent Dragen was destroyed hy the reformer llizekialı: or, it meams, also, the serpent with wings and feet, as used to be represented in funeral rituals.

Emboubtedly Ahraham lirought with him from Chaldea into lower Egryt symbols of simple phallic deities. The references in the Sible to the Teraphim of . Taeob's family remind us that Terah was the name of Abraham s father and that he was a maker of images. Indoulderlly the Teraphim were the same as the Seraphim; that is, were serpent-images and were the homsehold charms of the Semitic worshippers of the sun-god to whom the serpent was sacrerl. In Numbers, 
xxi, the serpent-symbel of the Exodus is called al sulpht; moreover,

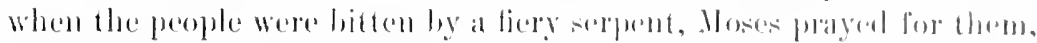
when fehorah replied: "Make them a liely serpent (liturally seraph)

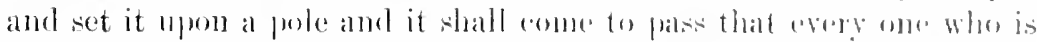

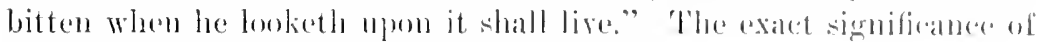
this healing figure of the serpent is lar to secels.

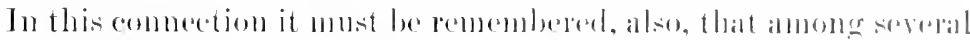

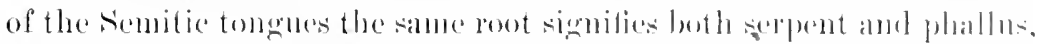

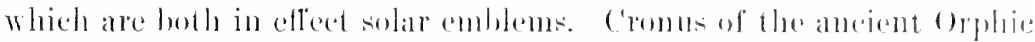

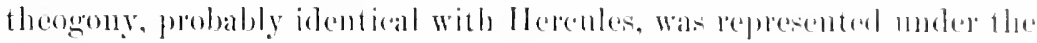
mixed emblem of a lion and a serpent, or often a serpent alome. Ho was originally considered supurme, as is shown from his being eallerl Il, which is the same ats the liebrew El, which was, alecorting to st.

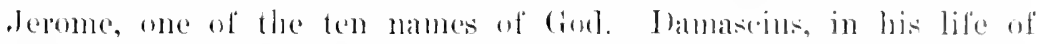
lsielorus, mentions that cromus was worshipued under the name of Eil. Brabun, C'roms, and Kincph eateh represented the mystical union of the reciprocal or active and pasive regenerative principles.

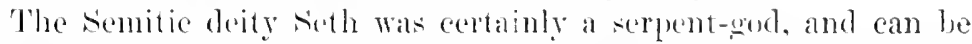
identified with Saturn and deities of other prople. 'The common name of Ciod. Elouh, anong the Ilebrews and other semites goes balek to the earliest times; indeed. Pryant goes so far as to say that lil was the original name of the supreme deity among all the nations of the liast. Ile was the same as Cronns, who, again, was the primerat saturn. 'Thus Saturn and El were the same deity, and, like seth, were symbolized by the serpent.

On the Westem Continent this great mity was equally reeognized; in Mexico as Teotl; in Pern as Varicoclar, or the Soul of the Eniverse; in Central America and Yucatan as Stumah Ku, or God of Gods. In the Aztec Pantheon all other gods and goddesses were practically modified impersonations of these two principles. In the simpler mythology of Peru these principles took the form of the sum and his wife the Moon.

Among the annals of the Mexieans the woman whose name olu Spanish writers translated "The Wroman of our Fish" is always represented as acempanied by a great male serpent. This serpent is the Sun-god, the principal deity of the Jexican Pintheon, while the name which they gire to the goddess-mother of primitive man signifies "Woman of the Serpent."

Inseparably comnected with the serpent as a phallic cmblem are also the pramids, and, as is well known. pyramids abound in Mexico 
and Central America. As Ilumboldt years ago observed, pyramids existed thromgh Mexico, in the forests of lidyntha, at a short distance above sea-level: on the plains of Cholula anel of 'Teotihnacan, at an elevation which exceeds those of the palseses of the Alps. In most wilely distant nations, in climates mos different, man seems to have atopted the same style of construction, the sime ornaments, the same customs, and to have placed himself under the gorermment of the same political institutions. Nayer, describing one of his trips, says: "I constantly saw serpents in the city of Mexico carved in stone, and in the various eollections of antiquities." 'Tle smbolic featherel serpent was lỵ no means peculial to Mexico and Yucatan. Sipuier encountered it in Nicaraugua, on the summits of voleanie ridges; even amomer our historic Indian tribes, for example, among the Lenni Lenape, they called the rattlesnake "grandfather" and male offerings of tobacco to it. Furthermore, in most of the Indian traditions of the Manitou the great serpent figures most conspienously.

It has heen often said that every feature of the religion of the new world discovered by Cortez and Pizarro indicates a common origin for the superstitions of both enntinents. for we have the same worship of the sum, the same pylamidal monuments, and the same reneration of the serpent everywhere. Thus it will be seen that the serpent-symbol hal a wide aceeptance upon this continent as well as the other, and among the uncivilized and semibarlaric races: that it entered widely into all spmbolic representation with an almost universal significance. Perhaps the latest evidences of this helief may he seen in the tradition ascribing to St. Patrick credit for having driven all the serpents from Irish soil. or in the perpetuation of rites, festivals, and representations whose obsolete origin is now forgotten. For instance. the annual Mayday festival. scarcely yet discontinued. is certainly of this origin, yet few, if any, of those who participate in it are aware that it is only the perpetuation of the rernal solar festival of Baal and that the garlanded Iay-pole was anciently a phallic emblem.

Among men of my own eraft. the traditions of Esenlapins are prevalent. Esemlapins is. howerer, inseparahly connected with the serpent-myth. and in statues and pirtures is almost always represented in connection with a serpent. Thus he is seen with the Caducens, or the winged wand entwined by two serpents. or sometimes with serpents bodies wombl around his own; rarely if ever without some serpent-emblem. Moreover, the Cadncens is identieal with the simple figure of the cross. by which its inventor Thoth is said to 
have symbolized the four alements proceeding from a common center. In connection with the cross it is interesting alson that in many places in the liast serpent-worthip wats not immediatnly destroyed by the aldrent of C'hristianity. The Cinostico, for cammele, among Christian seets, mited it with the religron of the crose, ans might be shown by many quotations by religrions writers. 'l'he serepent elinging to the cross was used als a strmbel of ('hrist, and a form of Christian serpent-worship was for a long time in vogue anmong many beside the prolessed Ophites. In the celebration of the biacelace mysteries, the mystery of religion, as nsmal throughout the world, was concealed in a chest or box. The lsraelites had their sacred Ark, and every nation has had some sacred receptacle for holy things and symbols. 'The worshippers of Pacehus carried in their consecrated baskets the mystery of their (iod, while after their banquet it was minal to pass around the eup, which was called the "Cup of the Cood bimmon," whose symbol was a serpent. This was long before the institution of the rite of the last supper. The fable of the method loy which the grod Asculapius was brought from Epidaurus to Rome, and the serpentine form in which he appeared hefore his arrival in lome for the purpose of checking the terrible pestilence, are well known. The serpentine columm which still stands in the old race-course in Constantinople is certainly a relic of serjent-workip, though this fact was not appreciated by Constantine when he set it up.

The significance of the ark is not to be overlooked. First, Noah was directed to take with him into the ark animals of erery lind. Jint this historical absurdity, read aright and in its true phallic sense, means that the ark was the sacred Argha of Ilindon mythology, which, like the moon, in Zoroastrian teachings, carries in itself the germs of all things: read in this sense the thing is no longer incomprehensible. As En al rehe (in the beginning), Elohim ereated the hearens and the earth, so in the ark were the seeds of all things preserved that they might again repopmlate the earth. 'Thus this ark of Noah, or of Osiris, the primeval ship whose navigation has been ascribed to various mythological beings, was in fact the moon, or the ship of the sm. in which his seed is supposed to be hidden until it hursts forth in new life and power. But the dove. which figures so conspienously in the Biblical legend, was consecrated to Tenus, in all her different names, in Balylon, in Srria, in Palestine, and in Greece: it cren attended upon Tamus in his Toyage of the Golien Fleece. And so the story of Jonah going to Joppa. a sea-port where Dagon, the fish-god, was wor- 
shipped, and of the great fish, hear's a suspicious relation to the same cult. for the fish was revered at Ioppla as wis the dore at Nineveh.

It has been imposilide to disasociate serpents and serpentworship from Esculapius. This is not beealse this mythologieal divinity is smpersed to have been the fomnder of our profession, but becalse he has given at all times a serpentine form and has been, apparenty, on the most familiar terms with the animal. l'ansanias, indeed, assures us that he often appeared in serpentine form, and the Roman eitizens of two thomsand years ago saw in this "God in reptilian form an olject of high regard aml worship." When this divinity was inviter to make liome his home, in aecordance with the oraele, he is represented as saying:-

"I come to leare my shrine:

This serpent-riew, that with ambitious play

My stafl encereles, mark him erery way;

His form-though larger, nobler-Ill assume, And, changed as gods should be, bring aid to liome."

(Orid, Metamorphoses, $\mathrm{XV}$.)

When in due time this salutary serpent arrived upon the island in the 'Tiber, he began to assume his natural form, whatever that might have been:-

"And now no more the drooping eity mourns;

Joy is again restored and health returns."

Considering, then, the intimate relation between the founder of merlicine and the serpent, it will not seem strange that the serpentmyth is a sulject of keen interest to every student of the history of medicine.

This devotion to serpent-worship appears to have lingered a long time in [taly, for so late as the year 1001 a bronze serpent on the basilica of St. Ambrose was worshipped. De Cubernatis, speaking of it. says: "Some say it was the serpent of Asculapius, others Moses, others that it was the image of Christ: for 11 is is enough to remark that it was a mythological serpent hefore which the Milanese mothers oflered their children when they suffered from worms, in order to relieve them": a practice which was finally suppressed by San Carlo. Ioreover, there has persisted until reeently what is ealled a snake: 


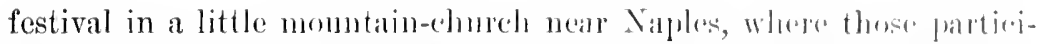

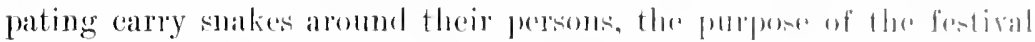
being to preserve the participants from poison and suderen death and bring them good fortune (sozinskey).

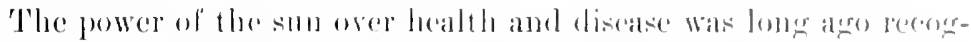
nized in the old chaldean lymm, in which the sun is petitioned thus:-

"l'hou at thy coming cure the race of man;

Canse the ray of health to shine upous him;

Cure his discuse."

Probably some ferling alin to that roiced in this way gave rise to the following beatutiful pasage in Malachij, iv, "2: "l'he sum of Righteousness shall arise with healing in his wings."

As a purely medieal symbol the serpent is meant to spmbolize prudence; long ago men were enjoined to be as "Whise as serpents," as well as hamless as doves. In India the serpent is still regarded as a symbol of every species of learning. It has also another medical meaning, namely, convalescence, for which there is allorded some groum in the remarkable change which it undergoes every spring from a state of kethargy to one of active life.

According to Ferguson, the experience of Moses and the C'bildren of Isracl with brazen serpents led to the first recorded workhip paje to the serpent, which is also noteworthy, since the canse of this adoration is said to have been its intrinsie bealing power. 'The prototye of the brazen serpent of Moses in latter times was the Goof fonius, the Agathodamon of the Greeks, which was regarded always with the greatest favor and usually aceorded eonsiderable power over discase.

The superstitions tendeney to regard disease and leath as the visitation of a more or less eapricions act by some extramundme power persists even to the present day. For example, in the Episeopal Book of Common Prayer it is stated, in the Order for the Visitation of the Sick: "Wherefore, whatsoever yomr sickness he, know you certainly that it is God's visitation"; while for reliof the following sentiment is formulated in prayer, "Lord. look down from hearen, hehold, visit, and relieve these thy servants." thus voieing the very ideas which were current among varions peoples of remote antiguity. and eliminating all possibility of such a thing as the regulation of disease or of sanitary medicine.

I began this essay with the intention of demonstrating the recon- 
dite, but positive, connection between the symbolism of the church of to-day and the plallic and iatric eults of prechristian centuries. Is a humble disciple of that Esculapius who was the reputed founder of our eraft, I have felt that erery genuine scholar in medicine should be familiar with these relations between the past and the present. 


\section{INDEX.}

Arlvanes in other sciences, 153

Airiclius. 77

Ascelepianle, 11

Ascolitpins, 7

Atius, 4!)

Aere of fomudation, 12

Age of removation, 12

Age of transition, l:

Anuew, 1). Hatyen, :295

Akrisicle, :21:3

Alfinas, lo.1

Allucassis, (ii3

Aledemists and charlatans, the, 187

Alehemy, 111

Mexamilue of Tralles, 50

Aleximdria, libary of, :31 sithoml of , 3:2

Alkindus, (6)

Ambulant physicians, 17

Amemlument in merlieal aflatis, 151

Ameriean teaching of to-day, sto

Amphitheatres, dissecting, 111

Amositit, :269

Anesthesia, history of, 800

Anatomie periosl, i: : :o

Amatomy amil plupsiology of Galen, 39

Anatomy, chalies of, 111

Amlial, :2.5

Andry, 178

Anel, :215

Animaleulists, 183

Animism, 196

Animists, 183

Antiseptries, history of, 317

Antyllus, 51

Arabic period. 12, 57

review of the, 97

Arehiaters, 53

Aretieus, 36

Argentier, .John, ] 16

Aristotle, 28

Arlt, 253

Arnold de Villeneuve, 88

Aselepiades of Bithynia, 44

Aselli, 160

Astrology, 141

Astrue, i3s, 214

Aubrey, $18: 3$

Auentirugger, Teopold, 210

Auseultation, 262

Avenzoar, 64t

Averrous, 64

Aricenna, 61

Baehe, Franklin. 287

Bachtischua. 59)

Bacon, Tord. 153

Baeon, Roger, 68

Baglivi, 162, 172

Baillie, 213, 224
Barlat, 16is

lialthlo\%,

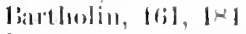

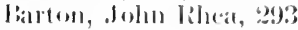

liatsullare, : 14

lialy la, :15,

licil, linajamin, :2]!

liell, follit, :219

litll, sil ('halles, 219), 271

bollini, 17:2

lixuiviani, 1]1

liermarl, Clamele, 217

linmard, the l'rovincial, 78

Jihamg, :301

liclatt, 1601) 169, 166, 205

Pinclatise, 178

ligelow, Ilemry J., : :9.5

liilemer, :215

lisiliroth, Theodor, 261

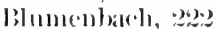

Buchlative, 1938 intlucuese of, 168

Boerhate's clinies, 167 system of medicine, 191 theory of inflammation, 164

Bommet, 250

Jionlen, :(0)

liorelli, 160, 17:

liniti, 176

leotal, lowmard, 146

Jiouchut, :59

Toyere, :26\%

Boyleton, Ins, 279

Bouillaud, 24t

Bonlot, 177

Bonrgenis, Lonise, 166

Braid, 1)r. James, 204

Braiclism. 204

Brainalrel, Daniel, 295

Brasilor, 214

Brigham. 290

Brisseatu, 178

Brissot, praetice of bleeding br, $11 \mathrm{~s}$

British surgeons, modern, 275

Brodie, Sir Belljamin, 273

Brollssais, 243

Brown, 1)r. John, 205

Browne, Sir Thomas, 175

Brunner, 183

Brunonian doetrine. 205

Burk. Giulon. 293

Bumstead, Freeman J., 289

Pwrking, 231

Cahalistie theory. J41

Cosarean operation, re-establishment of. 134

Camper, leter, 219

Cardan. Jerome. 142

Cardinal powder, 16.5 
Casserius, 162

Catiract, tirst recognition of its seat, iss

Cathedral nedical sebools, 89

(c)ll. the term, 1.53

(collular patlologr, 2.06

Colsus, Cormeilus, 34

(e-all pinus, 1.i.)

Chamberlain's invention of obstetrie forerpes. libi

Chapman. Nilthanicl. №

('latritable institutions. ancient. 5.5

('hemicall sistem of medicine, log

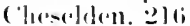

('herne. Jolint. 24s

chinese medieine of the. 5

('hi]on. 7

C'loloform, risovery of $30 ; 3$

simpens: introduction of, 313

Chopart. 314

Circulat ion. (apillary, discovery of. 1 js discorely of the, 15.j, 160 lesing, 11] 2

fatilure to dircover the, 113

Civiale. 2 (i!)

('lark, Nlonzo, 2xis

Clissification of events in the history of merlicine. 12

Clinical teaching. earlient systematic. $16 i$

('oquet. 20i9)

C'nicli- Temple of Fsculapius at, 9

(')(aine. 314

('ostion, desetrine of. 24

Colles. Al, ram. 204

Collot family of lithotomists, J

Colonial phirieians. 276

(columblus, 107. 1.5.)

Compisas. invention of the. 99

Constantine the Ifrican, it

Contratimole. 240

Cooper, Bransly, 2073

Simurl.

Sir Istley. 2 - 1

Comelius Igripun. 139

Corpun-eles of the blood. first discovery of, lis

Corvisart. les

Co: 19$)$

Tomple of Esculapius at, 9

Cosmogens, Cireek, 13

Comntris powder, 165

Cowper, 158. 189. 183

Cox, Jolın R., 280

Crisis. doctrine of. 25

Cruveilhier. 245

C'ullen. William. 198

Curric. 229

Czermak. 2.53 1)alton, dohn C., 288

Darw in, Chatrles. 237

Erasm11s, 2102

Daviel. $: 21 . \overline{3}$

Do (iratif. Is:3

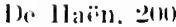

De la Marehe. Marguerite, 182

Delafiek!, Elwarel, e.?3)

De lalmay, 17

Delamotte. Ititi, 15:2

Dedpech, 2 (is

Me Malroule. 17i

Denis. Inalu biaptiste. 170

1)emman. Thomats. $2: 20$

1)elltal sllogery, the lirst eoliege of, 341

Dentistry. ancient and mediacral. 332

as al -peedialty of medicine, 337

in America, 341

of proluistoric times. 331

relation of, to modern surgieal pathology, 341

Desault. 1'. ..., 214,260

1)erenter, lisci

Dewers. Milliam P., $28 s$

1)iagnosic. exalet methods in, 263

Dionis, l'ierre. 17i

J)isicetion. ceremonial- previous to, 149 diflicolties attending. 103

of human bodies. 3:

Doctor's mol, in New York, 284

bodart. 17:2

bonders, -2.53

Fiberle, Joln, 286

Eirlectios, 14, 46

limbalming, 3

Empedorles, 17

Empirios, 14

Engraving, 100

Engravings. first anatomical. 112

Epidaurms. Temple of Esculajius at, 10.

Erasistratus. 34

Erudite period. 13

Esyuirol. 20:

Ether, silphuric, as an anasthetic, 302

Eustachius, 107

Eve, l'aul F., 294.

Fabre. Ifot

Fabricius ab Aquapendente. 109

Falmicius Hildanus. 110, 17s

Fallopius, log

Finst, 100

Fermentation. the causes of, 319

Fernel, Jean. 115

Fillelis, on legal medieine, I67

Filkin. 217

First hospitals in United States, 283 
First medieal solnools in the United Statc's, 281

flint, Austin, 20s

Jothergitl, Johnt, 212

Francis, John W., 2860

Jiank, .l. I'., 2I 2

frime, comse, 2014

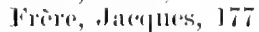

Finck, 2 !n)

linells, :-5is

Functions of the spinal nerves, discovery of the, 248

Gaddesden, John, 87

Galen, anatomy and physiology of, 39

Galcon, ('latudius, 36

Galen's intluence, 43 theorices, 39$)$

Garliner, lag

(atringeot, 2t3

(atul, 19.)

Gerarel of Cremona, 90

Gerely, 270

Germiciles, inlermal use of, 329

Germ-theory of discases, 259 what if means, $32: 3$

Gilson, Irilliam, 20(i3)

(iilbert, of bingland, 87

(iimbermat. 215

(rlissom, 1163, 183

Goerter. 11i:3

Goode, bohn Mason, 247

Goodwin, J(6)

Goursand, 175

Gracfe, 253

Graves, liobert, 248

Gray, John l'., 2!)

Greece, medieine of, 16

areek periol. 12, 49

Grecory, 19!!

Gricsinger, 254

Gross, Samuel D. 294

Guillemein, Jacob, 131

Gumm. Mloses, 2955

Guthrie. ?2:3

Guttenloce. 100

Guy de Chauliae. 93

Gymnasia, the, 18

Gymmasiareh, is

Gymmast, 18

Hahn, 229

Hahmemann, 241

Haller, 160, 162, 163, 220

Haly-Ablas (i)

Hamilton. Frank H., 293

Harver, Gideon, 175

William. 155

Hasheesh, 301

Hasner, 253
11 arcers, 18.3

Hexidin, 210

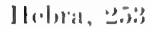

Ilanews, Inemlicine of the, :3

Iloistor, 21.5

Ilotrolitis, loto

Ilomle, 色)

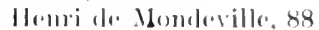

Ilompluilus, 333

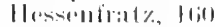

Ilourue, olta de, introduction of bed side instruction lig, ltit

Ifowsom, I(i]

llivin liblus, :3

Ilighmone, Is:3

Ilipporiaters, I!)

Ilirudinomamiat, ․․t

llobuken, lsis

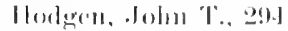

Ilolfuam, (lariatopher londwigr. 200

Ilotlumam, Findrich, 1!7

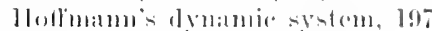

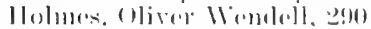

Heme, sir Evorard, 204

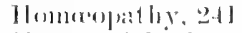

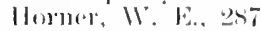

Mlspitals and aljois, 231

Iloward, Jolm, 212

Ilufelanel. ㅁำ

Ilumanization of vaecine-virus. 2.28

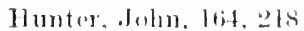
IVilliam, 218

Hunter"s study of the lymplatic svstom. the. J6il

Iluxham, lohn, 리를

Hydetheripentir - sytem, 2.55

Hychotheray, az?

Iatrochemical system, 169

latroliptes. is

latromechaniond solool, 17]

Infaretus, doctrine of, 黑ol

Intluesere of botany on medicine. 237

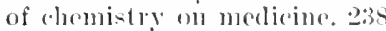

of lanwin and speneer on medirine, 237

of Ilarvey's diseovery. 1.5?

of pliysires on medirine. 23s

of the art of printines. 1(6)

of the Frende lievolution, 191

of the Northern inviders, 71

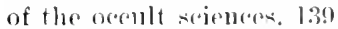

of the Sillerian seltool. Sl

of zoiilogy on modicine. 238

Inoculation, against small-pox, in America, 279.

Inoculation, preventive, against smallpox. 2.5

witl cow-pox, the first. 220 
Irritability of tissues, discovery of, lis3 lsoputhy, 24 l

lackson. ('harles T., 310

Jacolus sylvius, 103

I:ierer, 2.83

Jenner, lilward, 2-20;

lesuit powder, ]6i.s

lews. prejulice alginst the. 233

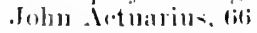

Iohn of l'rocidac, 7!

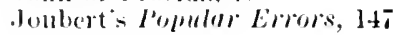

liamprif : 201

kicpler. I (i)

lieves, Dit!

lirkbride, 290

Lammee, 2602

lamballe, loubert de, $\leq 70$

lancinits alinic, 168

limframe, !l

Langenberek, Bembard ron, 264

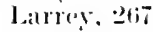

Lalvoi:ier, 160, 19]

Lawrence. Sir William, 274

Le Boe, lit., 169

le ('at, 2It

le Drin. 213

Leonicenus. Nicholas, 101

L(ittsom. :13

Leenwenhock. 158

Lerret's modification of obstetrieal forceps. 166 i

Ligatures, first use of, in amputations, $1 \cdot 27$

Linacre, Thomas, 101

Linmaxus. 19!

Jisframe. 2069

Lister, $2(i)$

Lister's stulies and methods. 32.5 work, benefits of, 327

Liston, Rolyert, 2it

Lithotomv, lateral, inventor of, 177

Lizars, Jolin, 274

Lomer. Craw ford, 304

Lorry, 2.28

Jouls. 24 ;

Lymple, discovery of the cireulation of, 158

Machaon, 10

Iref'lellatn, George. 293

M(cl)owell, Ephraim, 267,292

Magati, 170

llagendie, 246

Magie. 1+1

Magnetism, animal, 203

Maimonides. 65

Maitre. Jean. 178

Malgaigne, 270
Malpighi. los

Maneliagorat. 301

Mitreellu- I) Dnatus, 115

March. Mlden. :29.5

Marchetti, 1.5s, 176

Maresulal, fieorges, 178

M:arimats, 4:3

Mirjolin. :20!1

Ma-ranui. llil

Maturiceall. I6ti, 18:2

Mautlomer. 2..53

Nlayow, l(i)

Mriul. litehard, 2]3

Mechanicu-dynamic system of medi(ine. 197

Nerekel. Iri:

Medi al jomrnal in the [nitel States, first. :-2is.)

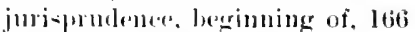

schowl of the nattural seiences, 258

-tmly under preceptors, 27

crotems, promulgation of, 152

Medici puri. preten-ims of, ls!

Medicine, and -urgery, approach of, $1+7$

dugmatic schoon of, 13

Iniperial shomol of, at Pekin, 6 phyiological theory of. 243 sejaration of priesthood from, 147

Mejhom, lint

Meigs. Iohn Fursyth, 289

Nelampins, t;

Mesmer. lrank. 203

Mesmeri=m. 2013

Mesue. (in)

Metlic li-m. 13, 45

Mlierosenpe. lon

Midwifery during the seventeenth century, advance of, 182

Nirkives, ltio

Monclimo. (6)

Monro. Alexander. Sr.. 210

Alexamder, second and third, 216 1)mald. 2016

Nomrose the two. Jot

Ximt pelliur, the school of, 86

Morand. 213

Norel. lit;

Morgigni. 2024

Morton. Richard. li.

Willian T. G.. 306

Mott. Valentine, 293

Miiller. 2022

Mrunir.h C'linieal School, 258

Muralt, Iso

Mutter, Thomas 1)., 293

Mrstic perind, 12

Natural history. the sehool of, 249

Natural philosophy, the school of, 249 
Needliam, 183

Nelitom, 270

Nepentlie, 301

Now Viculua School, 250

Nitrous-oxide gas, 30.3

Nominalist, (i?)

Nuck, Is:3

Olstetrical forcepse invention of the, I 6 (6ij

Obstetricions and gymorologists, Ameri(am, 29)

Obstotries, development of, 166

()ken, 24 !)

Ophithalmoseope, 263

()pol\%er, 2.53

()ribasius, 4s

Orthopurdics, 0 igin of name, 177

Ovariotomy, the first, 2 (i7

Paterhiomi, 183

Palfy'n's olstetrical foreeps, 166

laracelsus, 143

Pari, Ambroise, le3

Pare and the surgeons of St. Come, 131

lark, Howry, 217

Darker, Willard, 293

Panlus sogineta, 51

l'ecipluet, loil

P'ereussion, invention of the art of, 210

Pergamos, library of, 30

Periodie physicians, 17

Peruvian hark, diseovery of, 164

Petit. J. I., 213

Peu, lico

Peyer, 183

Peyronie, 213

Pfenfer, 254

Pharmacojolists, 54

Philosophis" period. 12, 18

Phrenology, 163,242

Physienl examination, methods of, 263

Physick, Philip, S., 29]

Physiological medicine, 253

Pinel. 163, 196, 206, 228

Piorry. 262

Pitard, John, 92

Plater, Felix, 118

Plato, 27

Pleximeter, 263

Podalirius, 10

Porta, Giovanni Batista, 118

Portal, 223

Paul, 166, 182

Pott, Pereival, 217

Pravaz, 269

Praxagoras, 27

Priessnitz, 255

Primitive period, 12

Pringle, Sir John, 212
Ptolemy sinter, 31

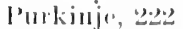

Pormamom, Isto

l'ythicgoris, 15

()uresuy, 173, 214

(quintus, 42

liadelille, 21:3

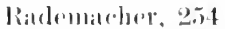

liapial multiphication of scientific literat 1110,239$)$

Rasori, 240

Rail, Iso

Riay, Isala, 290

Ray, dolur, 28?

Romilisur, 206

Riallist, (i!)

lieceptaculum chyli, discovery of, 16]

Reflex action, discovery of, 248

Reform period. 13

liegulation of practice in colonial

Reil, 202

$$
\text { times, } 285
$$

Roligions orders and the sick, 95

Rembert borloens, 115

Renss, 25,3

Rhazes, (60)

Rhinoplasty, 176

Rhorles, Temple of Esculapius at, 8

Richerand, 267

Richter, August Gottleib, 216

Riolin, 128

Rivinius. 183.

Rodger. .J. K.. 293

Roeschlanb, 240

Roger of Pilrma, 78

Roland of l'arma. 78

Rolfink, 188

Rome during the Greek period, 53

Rokitansky, 250

Roser, 253

Rousset and the Crsarean operation, $13 \pi$

Rolix, 269

Rufus of Epliesus, 42

Rush, Benjamin, 206, 283

Ruyseh, 158

Sabatier, 214

Saced period, 12

Salernmm, school of. 72

Sandifort, 219

Sands. Ilenry B., 203

Sanson, 209

Santoro, 171

Santoro's thernometer, 171

Sauvage, 190

Saviard, 177

Sealpel, first use of, in dissecting, 112 
Soarpa, 162, 215

Sichathausen. 183

frehucider, l62. 184

school of rational medieine, 254

seientitie societies and journals, origin of. 154

Salutetus, Iso

Sominalisu, :-5!!

Serapion. 60

Servetur, Miehalel, 112, 155

Severiun, 11!, 176

shomellor. Iow

Shot wounds, the new teaching of l'ar roncerning. 132

Sirgemmolin, Instine. IS2

Sigmumd, 2.53

Simpinom, Sir Jimes Y., 274

Sims, J. Marion, e?!6

Skodal, 251

Smellie. Milliam. 2020

Smellie: modifiation of the obstetricil forceps. l66

Smith, Nathan li.. $29 \cdot 2$

Societies aml academies, foundation of, 235

Soemmering, 162, 222

Soliclism, 1!s

spontaneous generation of life disproven. 3201

St. Côme. College of, 52.122

Stall. 195

Stalil's pietistic syste..., 195

Stemo, Nicholas. is9?

Steno's duct. 1.i?

Stethoseope. 20 i:

Stimolo and contrastimolo, 240

Stoerck, 200

Stokes. William, 248

Stoll, 2001

Student-life during the fifteenth and sixtcenth centuries. 148

Surgery, achievements of, 263 reisoms for neglect of, 120

Swammerlam, 153. 183

Sydenhim, 152. 165, 173

Sytrius. loi

syme, la s. 274

Syphilis, wirle-spread outbreak of. 136

Teeth, sulsititutes for human, 335

Telescope, invention of the, 99

Tenou. 215

Thaer, 199

Themison. 44

Theory of excitement. 240

Theosopliy. 141

Thermometer, discovery of the, 171

Thoth, 2

Tourniquet, invention of, 176

Tomrniquet, serew, invention of, 213
Transfusion of blood in man, the first, liti

Travers, Benjamin, 248,273

Treatment of the insane, improvement in, 2:28

Treja, :202

Trutula, 79

Trousseitu. 247

T'ïrek. 2.53

Tyrrel. 273

Universities and royal scientific societies, 192

Varcination, eompulsory, 228

in the I nited states, the first, 279

the first. 2027

Vagadasastir. 4

Vilsillia, Iti

Van limen. William H., 289

Van Hohnont. 16s

Van lfolmont's system of medicine. lis

Van Sichold, 216

Van swipten. lis

Van Swieten and the Old Vienna s(hool, 199

Velpeall. 270

Venesection. first account of, 10 revival of. llst.

Verulam, hord, 15:3

Veanlins, Andreas. 104

Yica d'Azyr, ] li2, 164, 223

Vidill, 269

Vieltssens, 162. 186

Virchow, lindolph, 255

Vitalism, 20] modern, 25.5

Wimman. 217

Warren. .John Collins, 291

Waterhomse, 1)r. 279

Wells, Ilorace, 305

Werlhof, 2ll

Wharton, 183

White. Anthony. 216 Chartes. 216

Wichman, 211

William of Salicet, 91

Villis, Tlomas. 163, 170

Winslow, 164, 223

Winternit2. 2.55

Wirsung. 183

Viseman. Richard. 180

Wistar. Caspar, 286

IVolf. 222.

IVood. George B., 287

Wren, Sir Christopher, 182

Wunderlich, 250, 254

Zeissel, 253 





\section{UNIVERSITY OF CALIFORNIA LIBRARY \\ Los Angeles}

This book is DUE on the last date stamped below. 


\section{tot}

\section{(ii)}

Biti

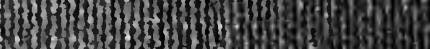

WI 